Lists of Swiss Emigrants in the Eighteenth Century to the American Colonies

VOLUME I

FAUST 
LERRELE
LIBRARY
UNVESSITY OF 







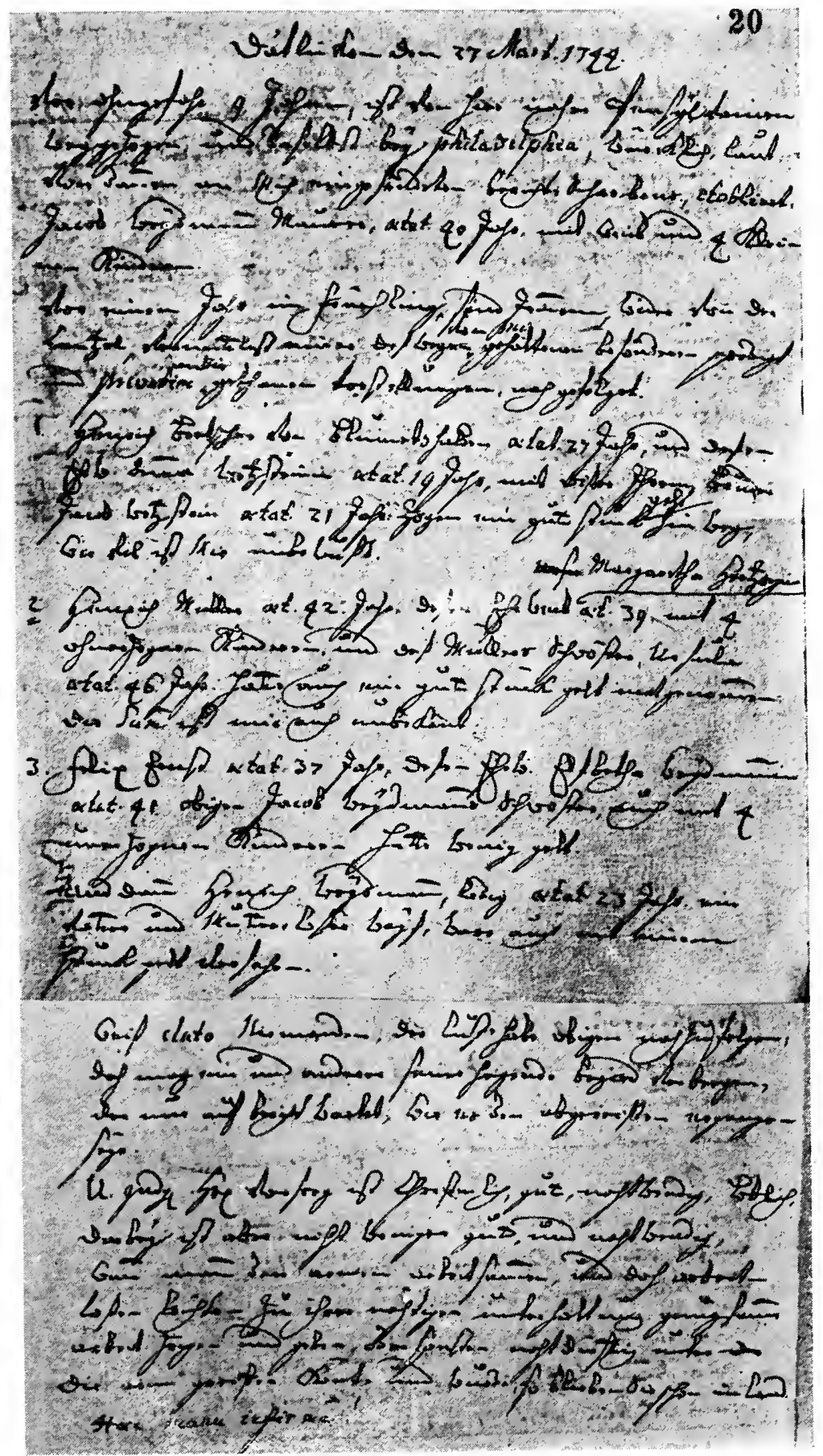

Reproduction of the Original List No, 20, Dättlikon, March 27, i744 


\title{
Lists of Swiss Emigrants in the Eighteenth Century to the American Colonies
}

\author{
VOLUME I
}

ZURICH, I734-I744

FROM THE ARCHIVES OF SWITZERLAND

$\mathrm{BY}$

ALBERT BERNHARDT FAUST, A.B., Ph.D.

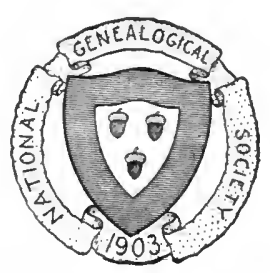

PUBLISHED BY

THE NATIONAL GENEALOGICAL SOCIETY

GAIUS Mr. BRUMBAUGG, Managing Editor

WASHINGTON, D. C.

1920 


\section{LOAN STACK}

Edition 500 copies, printed from type

Copyrighted, I920

By G. M. Brumbaugh, Editor 


\title{
Lists of Swiss Emigrants in the Eighteenth Century to the American Colonies
}

\author{
Zürich to Carolina And Pennsylvania, I734-I744
}

\section{PR EFACE}

THE manuscript here presented is contained in the State Archive of Zürich, and was discovered during a search it was my privilege to make after materials for American history in the archives of Switzerland. ${ }^{1}$ The manuscript is in many respects the most valuable single document relating to America contained in the Swiss archives, being quite as important for its historical as for its genealogical and statistical materials. The whole history of Swiss emigration in the eighteenth century is epitomized in this valuable document. ${ }^{2}$ The statistician finds in it the only reliable enumeration of Swiss emigrants of the early period, and is able to base far-reaching estimates thereupon. The genealogist is furnished with a large mass of family records, including about two thousand names with accurate data as to origin, distribution and destination.

This large body of names supplements the lists of I. D. Rupp, in his collection of Thirty Thousand Names, of German, Swiss, Dutch, French, and other Immigrants in Pennsylvania, from I737I776, compiled mainly from the ship lists in Philadelphia. Many of the names in the manuscript will be found also in Rupp's collection, and it is a pleasure to know that so many persons reached their destination. But a still larger number are not contained in Rupp's lists, partly because the Philadelphia ship-lists do not give a complete record of all arrivals even in that port, and partly because a great many of those named in the manuscript were shipped to Carolina. Many of those who landed in Carolina, however, sub-

${ }^{1}$ See Guide to the Materials for American History in the Swiss and Austrian. Archives, by Albert B. Faust, Washington, D. C., I9I6. The search was made. under the auspices of the Carnegie Institution of Washington, Department of Historical Research, in the year I9I3.

${ }^{2} \mathrm{~A}$ fuller understanding of this important epoch in American history may be secured through the reprinted Swiss Emigration to the American Colonies in the Eighteenth Century, herein reproduced (see below, pp. I-25) through the courtesy of Dr. J. Franklin Jameson, Managing Editor of The American Historical Review. 
sequently settled in Pennsylvania. An interesting example of this is the case of the family Kölliker (Kelker), who very soon settled four miles from Lebanon, Pennsylvania. Our manuscript tells us that Heinrich Kölliker, with three sons and two daughters left

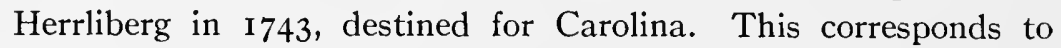
the family tradition which Rupp received from the great-grandson Rudolph F. Kelker, whose ancestor's name is not in the Philadelphia ship-lists. $^{3}$ Our manuscript moreover supplies not only the names of the parents, but also of all the children and their ages.

In order to understand the manuscript before us, it is necessary to bring before our minds the attitude of the European governments toward emigration in the eighteenth century. The liberality of view that developed in the nineteenth century, i.e., of toleration if not encouragement, and a disposition to aid the emigrant to a betterment of his condition, by means of transportation facilities and an intelligent view of what was before him, this humanitarian policy is modern. The old tradition was, that. emigration was a crime, and punishable as such, equivalent to desertion, a deliberate shirking of one's obvious duty to the fatherland.

There were economic reasons for this policy. The loss of sturdy people such as belonged to the emigrating class, meant so many hands less for the farms and trades, so many soldiers less for the protection of the country in a possible struggle for existence. The danger of over-population was not present in the eighteenth century, that became the problem of a later age. The enormous increase in population in Europe during the nineteenth century is one of the most remarkable facts in history, and brought to the foreground entirely new economic questions. Certainly the point of view on the question of emigration changed entirely. But in the manuscript before us we are dealing with an earlier age, when each government, especially in Central Europe, with the instinct of self-

\footnotetext{
${ }^{3}$ See Manuscript (MS), No. 42, and I. D. Rupp, Thirty Thousand Names, New edition, 1898 , p. 167 , note. Rupp reports a family tradition that Heinrich Kölliker and his family were twenty-eight weeks crossing the ocean, that two sons and one daughter died on the way, that they landed in Carolina, but that Heinrich Kölliker was an elder of "Berg Kirch" near Lebanon as early as I 745 . The certificate of character given the departing Köllikers and preserved by the descendants, is signed by the same pastor Conrad Ziegler who also sent in the report to the Zürich government in I744. The mother's name, according to our MS was "Rägula" Brätscher, but "Barbara" Brätscheri, according to Rupp's reading of the family certificate. It is probable that Rupp mistook the more frequent name Barbara for the less common Regula (probably badly written), and did not notice that the family name ended in "in" (not " $i$ "), a (feminine). termination frequently added to the names of women.
} 
preservation, jealously guarded its population against leaving its borders. An egress though slight might bring up the horror of depopulation and resultant annihilation. Martin Luther read into the thirty-seventh psalm the duty to remain in the fatherland and make an honest living therein. The seventeenth and eighteenth centuries tried to prohibit emigration by law.

Thus we find in Switzerland that during the most critical emigration period, between 1734 and $\mathrm{I} 750$, decrees or mandates were issued against emigration every few years, in I720, I735, I736, 1738 , and 1749 , again in 1753 , and 1754 , repeated in 1771 and 1773. The populous Protestant cantons Bern, Zürich and Basel were most affected, and of these Zürich proceeded most energetically against the so-called "emigration fever." She published the first severe edict, November 3, I734, forbidding emigration to Carolina, preventing property sales by those wishing to leave, and proclaiming punishments for agents and distributors of literature. This was followed shortly after by the mandate of January 29, I 735, which added sterner measures, deprivation of citizenship and landrights forever, penalties for purchasers of emigrant property and severe punishment of agitators. Bern and Basel did not act as promptly, the former retaining for a time the policy of favoring the emigration of the homeless and sectarian classes, the latter being obliged by her location to keep the gateway open. But as soon as they felt the dangerous force, they attempted by the same methods as Zürich to stem the rising tide.

Zürich had cause to be terrified. In some of her districts the "fever" of emigration produced something like a stampede, e.g., in the district of Eglisau, as the manuscript shows. It is hardly surprising therefore that, to get at the facts, the authorities of Zürich attempted to get a census of the emigrants. That is what the manuscript before us actually is. The central authorities, in the year $\mathbf{1 7 4 4}$, sent a circular letter to all the districts of Zürich, which in turn sent the message to all the parishes, demanding to know the names, with dates of birth, departure etc., of every man, woman and child who had left the country between I 734 and 1744 with the purpose of going to Pennsylvania or Carolina. The persons who executed the order were the local preachers, whose signatures appear in the manuscript attesting the accuracy of their reports. Each report is numbered, and there are as many as ninetyeight numbers or reports in the manuscript.

The reports are not alike either in form or content. Each minister chose a scheme of notation as he pleased. In some cases 
the date of birth, in others of baptism is recorded. The name is usually given in full, often the father's name and profession is added, sometimes an additional, a familiar name appears, the habit of calling and even recording persons by their nicknames being still prevalent in some parts of Switzerland. In cases of bondsmen, the name of the estate, or of journeymen, helpmates (Gesellen), the master's name is given for identification. Very commonly the trade of the men is stated, carpenters, joiners, turners, wheelwrights, wagon-builders, blacksmiths, locksmiths, masons, glaziers, weavers, shoe-makers and tailors abound, also very special trades are mentioned, as tilers, menders, rope-makers, resin-scrapers, hedge-, and scabbard-makers. The reports vary in matter from a bare statistical catalogue of names, to a gossiping letter. Most of the reports contain some notes or data which add to the human interest or fill out the historical background of the manuscript.

Most of the reports betray great anxiety to serve the cause of obstructing emigration, and in some cases an objectionable display of fawning servility appears in the communications to superiors. Some emphasize the speed with which their reply to the circular has been returned, the record-time being less than twenty-four hours; very many feel the necessity of apologizing for the departure of emigrants, calling attention to their paternal admonitions and repeated warnings concerning the dangers of the voyage and the false reports circulated about a land of plenty ("Schlaraffenland"), where sluggards have but to open their mouths for roast pigeons to fly in. A tendency existed to damage the reputations of those that departed, at least to represent them as an undesirable class, who had better be got rid of. On close inspection of the manuscript, however, it will be seen that the disorderly persons enumerated generally fainted by the wayside and rarely succeeded in getting across. The great bulk of those listed went with permission (though reluctantly given), which implies a certificate of good character from the pastor, when the contrary is not expressly stated.

Some of the pastors do not wish to curry favor, and a few boldly speak out, as the venerable pastor of Dättlikon, who says, that while the spiritual care of the people is essential, it would also be wise and good, to provide some form of work for the industrious unemployed, and then they would not be forced to emigrate. ${ }^{4}$ A sombre coloring appears in the report from Schlieren, where the emigrants left amid pitiable lamentations of several mothers. Touching in the report of the pastor of $\mathrm{Wyl}$ is the brief reference

4 See report No. 20. 
accompanying Heinrich Sigerist, who left with his wife and "a daughter ten years old, who can read and pray very well indeed."

The manuscript reveals much of the circumstances under which individuals were moved to emigrate. A very large number of the young people have lost their fathers, thereby missing either the parental protection at home, or the authority to curb their youthful spirit of adventure or "Wanderlust." Divorced persons and widowers are frequent, and widows with numerous children, who are allowed to go because of the fear that they might fall a burden to the community. Young couples leave their homes because of objections to their marriage, they are frequently united on the way or on ship-board. But economic distress exerts the strongest pressure. From Richtenschweil ${ }^{6}$ we hear of a group of emigrants who frankly declare, that they had to work day and night at home and even then they could not earn their daily bread, hence they were forced to leave. The hope of escaping unbearable conditions is the greatest driving power. Some left secretly to avoid the emigration tax, imposed so as to rescue some of the money that was leaving the country through the large emigration. The tax became as high as ten percent, ${ }^{7}$ and was exacted with rigor.

Favorable letters or verbal reports from returning travelers gave a great stimulus to emigration. This we see illustrated again in the manuscript before us. The voyage is dangerous, the deathrate high, but work and food are plentiful, and the hard-working succeed, that is the old story. Occasionally an offer of help is made, as when a successful settler ${ }^{8}$ promises to pay the transportation from London to America, if it be paid back in work on his farm. Those had the best chance to succeed who had a little money of their own, paupers very often were stranded on the way, or lay hopelessly at the ports.

An interesting study is furnished by the names. We have here an abundance of familiar Swiss and Palatine names such as Frick, Huber, Näff, Kunz, Kägi, Bär, Albrächt, Brunner, Frey, Fritschi, May, Wirt, Meyer and Müller. The transformation of such names into American spellings, and the many variant forms that appear in Pennsylvania and elsewhere, have been admirably treated by Professor Oscar Kuhns in his article Studies in Pennsylvania German Family Names, ${ }^{9}$ which will be reprinted in the new edition of his German and Swiss Settlements of Colonial Pennsylvania.

- Report No. 97.

${ }^{6}$ No. 68.

${ }^{7}$ See reprint from American Historical Review, below, p. I -25. $\quad{ }^{8}$ No. 80.

9 The studies in P. G. family names were first published in Americana Germanica, Vol. 4, pp. 299-341. The new edition of the German and Swiss Settlements etc. will be published by the Methodist Book Co. 
It is noticeable that Carolina is mentioned more frequently as the destination of emigrants than Pennsylvania. This is due to the fact that in Switzerland no part of the American colonies received more advertising than the Carolinas. The only two independent Swiss colonies in America were located, the one in North Carolina at New Bern (I7Io) by Graffenried, ${ }^{10}$ the other in South Carolina at Purrysburg (1732) by J. P. Purry. ${ }^{11}$ Naturally much of the emigrant literature had the Carolinas for its subject, and the old tradition held its own for a long time. The Orangeburg-Lexington district in South Carolina also received a quota of Swiss settlers, ${ }^{12}$ but migrations from one locality to another were very frequent. ${ }^{13}$ The great distributing center, however, for the whole colonial German population, was Pennsylvania.

It must be remembered, that the names in this manuscript do not give us a complete catalogue of all the Swiss who came to America in the eighteenth century, but merely those from the populous canton of Zürich at the time of the great exodus, I734I 744. ${ }^{14}$ The names are representative and will furnish many a family who have a tradition of Swiss descent with a clue to their Swiss ancestry. In many instances, as in the case of the Kelker (Köllicker) family, the manuscript will furnish a verification or correction of family tradition.

The German original of this manuscript was copied under the supervision of Professor Hans Nabholz, state archivist of Zürich, to whom grateful acknowledgments are due. The translation and editing of the manuscript in the form in which it here appears was done at Cornell University, under the direction and with the assistance of the undersigned.

IтHACA, N. Y., July 30, 1919.

Albert B. Faust.

${ }^{10}$ Cf. V. H. Todd, "Christoph von Graffenried and the Settlement of New Bern, N. C." (Jahrbuch d. D. A. Hist. Gesellschaft v. Illinois, 1912.) Also: German American Annals, n. s., XI, 210-302; and XII, 63-190.

${ }^{11}$ Cf. H. A. M. Smith, "Purrysburgh," South Carolina Hist. Mag., X, 187-219.

${ }^{12}$ Cf. A. S. Salley, The History of Orangeburg County, Orangeburg, S. C., I 898.

${ }^{13}$ Cf. A. B. Faust, The German Element in the United States, Boston, 1919, - Volume I, Chapters VIII (Carolinas) and X (Frontier). For bibliography on emigrant literature, Guide, supra, pp. 29-31. For traits of early German and Swiss settlers, see O. Kuhns, German and Swiss Settlers of Colonial Pennsylvania.

${ }^{14}$ Certain other rare and important lists of Emigrants to the American Colonies from Basel and Bern, Switzerland, of about the same period, are to be published in a subsequent volume, similar in character to this volume. Advance subscriptions will materially assist in the consummation of this project.

G. M. B. 


\section{TABLE OF CONTENTS}

Preface, by Albert B. Faust, A.B., Ph.D............ iii

Introduction: Swiss Emigration to the American Colonies in the Eighteenth Century. Reprinted from the American Historical Review, by Albert B. Faust, A.B., Ph.D.... I-25

The Manuscript: Zürich to Carolina and Pennsylvania,

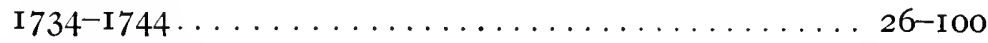
Appendix: Movements of Swiss Emigrants in the American

Colonies, by Gaius M. Brumbaugh, M.S., M.D. ... IOI-IO2 Index ............................. 10 



\section{ILLUSTRATIONS}

Facing page

I List No. 20, Dättlikon, March 27, I744 (Facsimile). Title Page

2 List No. 30, Erlenbach, May I, I 744 (Facsimile)....... 49

3 List No. 72, Schlieren, April 3, I 744 (Facsimile)....... 78

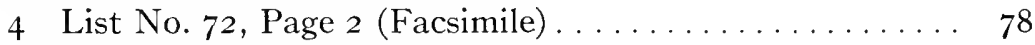

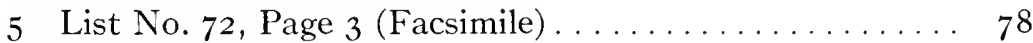

6 List No. 72 , Page 4 (Facsimile) ............. 78

7 Reproduction of Transcript of List No. $72 \ldots \ldots \ldots \ldots 78$

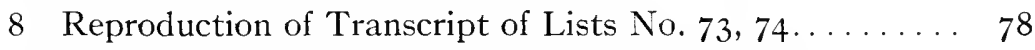

9 List No. 73, "Parish Schäfflistorf, Since I734 "(Facsimile). 79

Io List No. 74, Parish Schwerzenbach (Facsimile)........ . 80

I I List No. 87, Wädeschweil (Facsimile) . . . . . . . . . . 92

' 2 Ship Captain's List of Inhabitants of the Canton of Bern,

Imported from South Carolina, Philadelphia, August

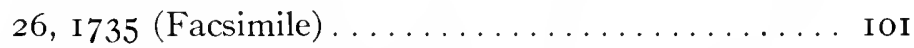

I 3 Page 2 of the Above, Including Men, Women and Children

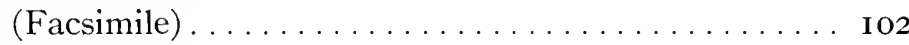

I4 Oath of Allegiance List of the Above (Facsimile) ...... I02 



\section{Swiss Emigration to the American Colonies in the Eighteenth Century*}

By ALBERT BERNHARdT FAUST, A.B., Ph.D.

THE many thousands of Swiss colonists who came to America in the eighteenth century directed their course mainly to Pennsylvania and Carolina, which they commonly believed to be parts of the West India Islands. Two colonies were founded under Swiss leadership, one in I 7 Io at New Bern, North Carolina, under Christoph von Graffenried, the other in I732 at Purrysburgh, South Carolina, promoted by Jean Pierre Purry of Neuchâtel. These colonies encountered all the hardships of pioneer settlements, extremes of heat and cold, fevers incident to the breaking of new ground, hostility of the natives, deficiencies in material equipment. Emigrants of the eighteenth century, before their arrival in the land of hope, had to endure the perils of the sea for months with slight protection and provision, they faced at best a decimation of their numbers on the crowded ships that conveyed them across, they were too often the victims of fraudulent captains and agents, who robbed them and sold them into servitude. All these trials and difficulties were borne and overcome by the early Swiss in common with all other sturdy and heroic pioneers of the eighteenth century.

But there is something distinctive about the emigration from Switzerland and that greater area of eighteenth-century emigration, the Palatinate and the upper Rhine country, the story of which has not been told. This is a record of hardship and obstruction at home, of barriers placed in the way of the emigrant by governments, of social ostracism, and of deprivation of all his rights and privileges. The home governments feared the loss of their people by emigration as much as they might by war or pestilence, and employed all means in their power to prevent it. For a study of this subject the materials found in the Swiss archives seem to be richer than those that have survived in the archives of the Palatinate and southern Germany, where in the eighteenth century the same policy prevailed of restricting, and if possible prohibiting, emigration. Conditions

* [Reprinted from The American Historical Review, Vol. XXII, No. I, pp. 2I-4I, Oct., I 916 , through the courtesy of Dr. J. Franklin Jameson, Managing Editor.] 
in Switzerland, therefore, may be assumed to illustrate also the situation for the German emigrant of the eighteenth century.

The only occasion when a Swiss government of the eighteenth century encouraged emigration was at the very beginning, and by the Council of Bern. This happened in the following way: in the years I7OI-I704 the Bernese traveller Franz Ludwig Michel made two trips to the American colonies, visiting Pennsylvania and Virginia mainly, with the object incidentally of selecting a site for a colony. His manuscript report $t^{1}$ on his journeys concludes with a draft of a petition to Queen Anne, proposing a Swiss settlement of from four to five hundred persons in Pennsylvania or Virginia under certain liberal conditions. The principal promoters of this plan were Georg Ritter and Rudolff Ochs, ${ }^{2}$ who succeeded as early as 1705 in interesting the Council of Bern and the English envoy Aglionby in the scheme. ${ }^{3}$

It is of importance to note the motives that impelled the government of Bern to take up the matter. Emigration of the virile and well-to-do elements of the population was not what they intended, but they saw an opportunity of ridding themselves of what seemed to them two very undesirable classes of people. One of these was a pauper element, the homeless Landsassen, squatters not citizens. The other was the sectarian class, Baptists, Anabaptists, or Mennonites (Wiedertäufer, Täufer). The latter particularly were considered a source of danger to both Church and State: their refusal to bear arms or hold office, their simplicity of worship and communistic tendencies, seemed to undermine the foundations of civil governments, of the Protestant and Catholic churches alike. The

1 This interesting manuscript is preserved in the Stadtbibliothek of Bern. Much of the German text of the manuscript has been printed in an article by J. H. Graf, entitled "Franz Ludwig Michel von Bern und seine ersten Reisen nach Amerika I70I-I704: ein Beitrag zur Vorgeschichte der Gründung von New-Berne," in the Neues Berner Taschenbuch, 1898, pp. 59-144. A translation into English of the complete manuscript has appeared in the Virginia Magazine of History, beginning in Jánuary, 1916, done by Professor William J. Hinke. The unique illustrations of the manuscript, including maps, the first building of the College of William and Mary, etc., are there reproduced to accompany the text; explanatory notes are also given.

${ }^{2}$ Joh. Rudolff Ochs compiled a descriptive work on Carolina, entitled: Amerikanischer Wegweiser oder Kurtze und Eigentliche Beschreibung der Englischen Provintzen in Nord-America, Sonderlich aber der Landschafft Carolina, mit Grossem Fleiss zusammen getragen und an den Tag gegeben durch Joh. Rudolf Ochs neben einer neuen $u$. correcten Land-Karten von Nord- und Sïd-Carolina (Bern, 17II). Fifty thalers were voted to the author by the Council of Bern for this printed work dedicated to them; see Ratsmanuale of Bern, March 21, I7I I.

${ }^{3} \mathrm{Cf}$. Faust, Guide to the Materials for American History in Swiss and Austrian Archives (Washington, I916), p. 37. 
most terrible and relentless persecution by courts specially appointed (Täufer-Kammer) and spies tracking the suspected to their homes (Täufer-Jäger), executions by fire and water (drowning, with intended irony), compulsory service in foreign armies or on the galleys of the Mediterranean, could not stop the spread of the sectarian doctrines. Deportation to the American colonies seemed to offer a hope of relief. Accordingly, the Council of Bern welcomed the opportunity offered by Ritter and Company, though they presented a double face, recommending America to the Mennonites as a place where they could obtain an abundance of food, while at the same time warning others against Pennsylvania, a desert, in which food supplies were altogether lacking, and from which the government felt duty-bound to hold its people back until longer experience had been gained. ${ }^{4}$

The expedition of Ritter did not start until March, I7 Io. We find an entry in the Ratsmanuale of Bern, that forty-five thalers a head were to be paid to Ritter for every Täufer he succeeded in bringing to America, and five hundred thalers more for another group of about one hundred emigrants (pauper class), who desired to go to America. ${ }^{5}$ The deportation of Ritter's group of Anabaptists proved a failure, though every possible precaution had been taken to prevent their escape. The Dutch Mennonites objected strenuously to the deportation of brothers of their faith, and refused to allow any to be carried through their country for the purpose of transportation to America, unless it were of their own free will. Of the forty-three men and eleven women composing the Täufer group, thirty-two were released at Mannheim owing to age and sickness, the remaining twenty-two gained their liberty at Nimwegen. ${ }^{6}$

Graffenried and Michel became members of the Ritter Company in I710, the former's connections with influential men in England, and the latter's experience, being of value in rescuing the Bernese emigration scheme from complete failure. A total purchase of I 7,500 acres was made and probably through the influence of the surveyor Lawson the land was located at the confluence of the Neuse and the Trent in North Carolina. At this time London was crowded with more than ten thousand Palatine emigrants desirous of being transported to the American colonies, and the problem of their sustenance and disposition was becoming very burdensome.

\footnotetext{
${ }^{4}$ Bern, Mandatenbuch, I 709, I 710 ; Bern, Ratsmanuale (RM.), XL. 238, 392.

${ }^{5}$ Bern, RM., XLI. 229, 28I, etc.

${ }^{6}$ Cf. Ernst Müller, Geschichte der Bernischen Täufer (Frauenfeld, I 895), pp. 252,278 , etc.
} 
Graffenried and Michel succeeded in getting about six hundred of them for their Carolina colony, and Graffenried had the privilege of choosing what seemed to him the most desirable persons. These and the remnant of Bernese emigrants made up several ship-loads of colonists for Graffenried's new settlement. The fortunes of New Bern in its beginnings have been told by the facile pen of the founder himself. ${ }^{7}$ He built better than he knew, under a luckier star than Peter Purry, whose town, so promising before the Revolutionary War, has left but a name in colonial history.

From the point of view of aiding the government in the deportation of undesirables, the Ritter agency was a total failure. Such a scheme was again discussed by the Berner Rat in $1710,^{8}$ with a proposition to buy land in one of the American colonies for this purpose. But the plan was dropped, and never taken up again. There was a return to the original position on the subject of emigration, that contained in the prohibitory decrees of the seventeenth century, ${ }^{9}$ punishing returning emigrants with loss of property and citizenship.

The old tradition forbade emigration. Leaving the country of one's birth seemed equivalent to desertion, and as desertion from the ranks was paid for with loss of life, so emigration was punishable with loss of all that the state deemed worth having, citizenship, property, land- and home-rights. Banishment, social ostracism, refusal of permission to return, imprisonment for life if caught returning, these were the conditions on which the emigrant gave up his country. Characteristic is the categorical command in the Lutheran translation of Psalm xxxvii. 3: "Bleibe im Lande und nähre dich redlich," which in the English version is an indefinite

\footnotetext{
7 The three manuscripts of Graffenried on the settlement of New Bern are described, and two of them printed, in German American Annals, n. s., XI. 205302, and XII. 63-190. See also Guide, pp. 73-75. IV. F. von Mülinen, librarian of the city of Bern, has written the authoritative account of the life and career of Graffenried, based throughout on the original manuscripts given him by the Graffenried family. Cf. Christoph von Graffenried, Landgraf von Carolina, Gründer von Neu-Bern, zumeist nach Familienpapieren und Copien seiner amtlichen Berichte, von Wolfgang Friedrich von Mülinen, Neujahrsblatt hrg. v. Historischen Verein des Kantons Bern für 1807 (Bern, I 896). A trustworthy and very readable account in English of Graffenried's settlement of New Bern has appeared in the Jahrbuch der Deutsch-Amerikanischen Historischen Gesellschaft von Illinois, Jahrgang I9I2, by Vincent H. Todd: "Christoph von Graffenried and the Founding of New Bern, N. C." The reprint is entitled: "Baron Christoph von Graffenried's New Bern Adventures."

${ }^{8}$ Bern, RM., XLI. 408.

${ }^{\circ}$ Bern, Mandatenbuch, I64I, I643, I660; see Guide, p. 33.
} 
promise of reward for good deeds. ${ }^{10}$ Remain in the land of thy forefathers and earn an honest living therein, is the admonition which Luther reads out of the Psalmist's text, and which is spoken out of his own heart. Emigration is sinful and its wages death, so judged the sixteenth, seventeenth, and most of the eighteenth century; the nineteenth introduced a more liberal view.

There were some good reasons for the policy of restricting, if not prohibiting, emigration in the eighteenth century. An able-bodied emigrant meant the loss of a defender of the land, and of an agricultural or industrial worker. Especially in the smaller countries of Central Europe a large loss of population might mean political or economic ruin. An increase of population seemed the result of good government, a decrease an indication of unsuccessful or incapable rulers. Many governments, particularly in Switzerland, assumed a paternal attitude toward their subjects, caring for their material and spiritual welfare, or at least pretending to do so. They felt this duty very keenly when it was to their advantage. Hearing that many emigrants were lost at sea, and that many others met insuperable difficulties after their arrival in the American colonies, they warned their subjects in fatherly fashion, and soon forbade their leaving, to save them against themselves. Similarly the Protestant governments were very much concerned for the spiritual welfare of such as might in 1720 take service in a Catholic province, ${ }^{11}$ or either church might object to its people going into a colony of sectarians. In 1716 the Ratsherren of Bern passed a resolution to allow only those to emigrate who could prove that they were well taught in religion (and were poor). ${ }^{12}$ Thus they endeavored to save the souls of their people, and at the same time to prevent the spread of heretical doctrines.

After the colonization scheme of I7 Io had quickly come to an end at Bern, no further attempts were made for a decade. The initiative then twice came from the neighboring principality of Neuchâtel (Neuenburg). In I720 a captain in the regiment Karrer by the name of Merveilleux (alias Wunderlich) attempted to secure recruits for service in (the island of) Mississippi. He seems to have succeeded in getting "several whole families of poor people," ${ }^{13}$ but

${ }^{10}$ Psalm xxxvii. 3 in the Lutheran Bible reads: "Hoffe auf den Herrn und thue Gutes; bleibe im Lande und nähre dich redlich." The English Bible interprets: "Trust in the Lord, and do good; so shalt thou dwell in the land, and verily thou shalt be fed."

${ }^{11}$ Expedition of Merveilleux, service in Mississippi region; see Guide, p. 4r, etc.

${ }^{12}$ Bern, RM., LXVIII. 36.

${ }^{13}$ Ibid., LXXXIV. 378; Erlach-Buch D., p. 66r. 
his scheme was vigorously opposed by Bern and other governments, partly owing to a distrust of overseas service, and partly on religious grounds, as described above. The other attempt was far more successful in course of time. It was the plan of Jean Pierre Purry of the firm Purry et Compagnie in Neuchâtel to found a colony in Carolina. He began to advertise as early as $\mathbf{1 7 2 5}$ for three or four hundred workingmen of different professions, all Swiss Protestants of good reputation and manners, between the ages of twenty and forty. In spite of his advertisements, ${ }^{14}$ spread broadcast and posted wherever possible, in which South Carolina was praised as one of the "finest countries in the universe," Purry did not make much headway until about five years later. He also published a book descriptive of Carolina, which was feared with good reason by paternal Swiss governments. In 1732 Purry established his colony of Purrysburgh with ninety-three colonists, to which there were soon added several hundred more. ${ }^{15}$ The settlement had a prosperous beginning in comparison with many others, and is noted in colonial history for its experiment in silk growing and manufacture.

Social and economic conditions favored an increase in emigration during the thirties and forties of the eighteenth century. In Bern, Zürich, Basel, Luzern, Appenzell, Fribourg, Vaud, and elsewhere, the ruling classes, often composed of a few patrician families, bore down heavily upon the city and country folk, depriving them of all possibility of rising above their wretched economic condition, and enacting offensive laws, such as those forbidding artisans to carry wares under the arcades (Lauben) of Bern, so that the patricians might walk through them in comfort, or closing the vegetable market to all but the noble class until i I a. m. Rebellion was the consequence, but unfortunately victory always remained with the aristocrats until the French Revolution awakened the Swiss people to a united stand for their liberties.

During this period Switzerland remained the recruiting ground for the powerful nations of Europe. Young Swiss noblemen found it a profitable business to equip and lead regiments in foreign armies, while their recruits, good soldiers who did not spare themselves,

\footnotetext{
${ }^{14}$ See Documents, F. Documents A-F, referred to on this and following pages, are contained in American Historical Review, Vol. XXII, No. 1 (October, 1916), pp. 88-132. Found in the state archives of Basel and Bern, they were published to accompany this article, and to illustrate problems relating to the Swiss emigration of the eighteenth century.

${ }^{15}$ Lists of their names are given in the authoritative account of the colony by Judge Henry A. M. Smith, entitled "Purrysburgh," in the South Carolina Historical Magazine, X. I87-219 (1909). See also Guide, p. 169, etc.
} 
received none of the bounteous rewards. A large percentage of officers and men, however, never returned to their homes. Swiss fought against Swiss on the battlefields of Europe, in the War of the Austrian Succession, as often before. It was estimated that in I 740 about 69,000 Swiss mercenary soldiers served in foreign armies, about 22,000 in French, 2400 in Austrian, 13,600 in Spanish, 10,600 in Sardinian, 20,400 in Dutch service. ${ }^{16}$

Add to these conditions periodic failures of crops, due to hailstorms and floods, as in the Bernese Oberland, and no sentimental ties nor governmental restrictions could restrain the desire for emigration. It is not surprising that at times this desire rose to a passion, that threatened to depopulate large sections and gave the governments good cause for alarm. Such an emigration epoch existed in Switzerland between 1730 and $175^{\circ}$, the high tide coming between 1734 and 1744 .

What started the movement it is difficult to say. Perhaps the continuous advertisements of J. P. Purry had the effect of touching the match to the powder-barrel. Perhaps favorable letters from colonists happy in the new country had been coming in for a long time, with the natural suggestion to follow after. At all events the emigration fever gave visible signs of becoming epidemic.

Zürich acted quickly, issuing a decree, November $3,1734,{ }^{17}$ forbidding her people to travel to Carolina, preventing the sale of property by those wishing to emigrate, proclaiming punishment of agents enticing people to emigrate or distributing seductive literature. This was followed after a few months by the decree of January 29, I735, which repeated the previous commands, and added sterner measures, deprivation of citizenship and land-rights forever, punishment also of the purchasers of property sold by emigrants, close watch over and severe punishment of persons enticing others to leave. The decrees were read from all the pulpits in town and country, they were posted in public places, yet $Z$ ürich, as the records show, found it necessary to let large numbers depart.

Bern did not act as promptly, nor with the same decision. She hesitated before sending an order, July 6, I734, to all the districts, warning against emigration to Carolina, restricting emigration to the homeless class and to sectarians, who were even to be assisted with

${ }^{16} \mathrm{Cf}$. Eröffnungsrede, gehalten in der Helvetischen Gesellschaft zu Langenthal, den 3I. Mai I 843, von Regierungsrat Fetscherin in Bern, pp. 84-85. Cf. also: Johannes Dierauer, Geschichte der Schweizerischen Eidgenossenschaft (Gotha, I9I 2), IV. 234.

${ }_{17}$ This decree and the one of 1735 are printed in full in the Guide, pp. 15-17. 
funds to get away. The policy of I 7 Io seems still to have held sway in the minds of many of the Ratsherren, that of using America as a colony for deportation of undesirables. A letter is written to Untersee, urging the Amtmann to explain to those desirous of leaving, that the "printed book on Carolina" contains falsehoods; those who can not be persuaded to remain, shall be taxed five per cent. of the value of their property (a tax raised to Io per cent. shortly after). In the meantime the gun-maker Striker (Stryger) of Steffisburg is suspected of being an emigrant agent, he is commanded to surrender his list of names, and in December he is banished from the country. Anxiously Bern inquires of Zürich, what she is doing to cure the "emigration fever." Zürich sends copies of her decrees forbidding emigration, whereupon Bern is roused to publish her first decree, January I2, I $7355^{18}$ warning her people of the Oberland against the trip to Carolina. It is a document altogether different from the Zürich decrees, in that it attempts to use persuasion rather than force. The Amtleute are to explain to those desirous of seeking their fortunes in Carolina, that the printed accounts on the subject are misleading, that the sea-journey is a long one, the change of air, the strange food, the lack of fresh water, occasion sickness and death among Swiss people, pirates on the sea sell them into slavery, and arriving in Carolina as paupers, they are obliged to sell themselves into servitude. Those who in spite of these warnings were determined to go, should not be prohibited from doing so, nor would they sacrifice the government's good-will, except those who possessed means valued at over five hundred pounds, who should be compelled to give up their citizenship and land-right. Emigration was not to be prohibited, but made distasteful, and the country was to be guarded against loss, as when persons of the homeless class were put into the places of those citizens who had left the district.

The records of the year $\mathbf{7} 735$ at Bern show continuous emigration. Investigations concerning Carolina are ordered and reports are received. On February 3 a vote is recorded that no more passports shall be given to emigrants, but on March 2, on their petition, 322 persons are allowed to leave for the American colonies, and on the next day another group of emigrants from Oberhasli are given permission, provided they have means to the extent of five hundred pounds, defraying their expenses, and provided children left behind be cared for. On March I3 three ships are designated to transport the greater part (Hauptschwarm) of the emigrants. ${ }^{19}$ On March

${ }^{18}$ The decree is printed in full in the Guide, pp. 34-35.

${ }^{19}$ Bern, RM., CXLVI. 215, 266, 270, 337. 
I 7 a group are given back the ten per cent. tax which they had already paid. If any of them desire to return, they can still buy back their property. If children do not desire to go with their parents, they are to receive a part of the family property. March 23 a complaint is received from the financial agent May in London concerning the distressing condition of Swiss (especially from Bern, Zürich, Graubünden) emigrants arriving there. Money is voted to bring them back, with one exception, for whom a guinea is sent to continue her journey to America. April 25 some success is reported in keeping back a group of highlanders of Oberhasli and Interlaken, and advice is asked concerning methods of providing for them. But, a few months after, the commissaire in London reports that a number of Bernese, desiring to go to Georgia, had arrived in England. On September 26 measures are taken against a certain person named Quinche of Neuchâtel, who is trying to entice people to go to Carolina (probably in the interests of Purrysburgh). This completes the record of the excitement at Bern for the year 1735 . The pressure of emigration proved irresistible. ${ }^{20}$

A vacillating policy in regard to emigration continued at Bern for a number of years more. An optimistic view was recorded on May 5, I 738: The emigration tax (Abzug) should not be increased, first, because of the attention thereby directed to it and consequent dissatisfaction, secondly, because emigration was on the "the RABIES CAROLINAE" had happily disappeared, and the people had allowed themselves to be persuaded by the sad fate of the best of the emigrants rather than by the paternal advice of the Ratsherren. ${ }^{21}$ But emigration had by no means stopped, it was destined to flow again, triumphantly, especially after i740. In I74I Hans Riemensperger of Toggenburg is planning to induce people to go with him to Carolina and Georgia, and his arrest is ordered. Neuchâtel is warned against him. Peter Huber is under suspicion the following year, when the "emigration fever" seems to start anew. "Auswanderung wieder lebhaft im Gang," is an entry in the record book on March I, I742. The Bernese highlanders are emigrating again in large numbers. Some are diverted from their purpose by offers of work in the French parts of the canton. In view of the danger the policy of Bern changes. A decree is issued April 26, I 742, forbidding all emigration to Carolina or elsewhere in America, under heavy penalties. A period of three months is allowed in

${ }^{20}$ See Guide, pp. 43-45.

${ }^{21}$ Säckelschreiber Protokolle, Y., Bern, May 5, I 738. 
which emigrants may return, after which loss of citizenship, landright, and property will be enforced. Property shall not be sent out of the country, but shall be forfeited to the community which the emigrant has left. Children under age (at the time of emigration) may return to their rights at any time, others shall be treated as agents attempting to entice people to emigrate. The decree yielded nothing in severity to those of Zürich published in $1734^{-}$ $\mathrm{I} 735$ and re-enforced in $\mathrm{I} 739, \mathrm{I} 74 \mathrm{I}$, and $\mathrm{I} 744$.

In spite of all exertions on the part of the government, so it is recorded February 17, 1744, people from the Oberland go to Carolina in hordes (haufenweise). They are allowed to go, but such as return are to be put into prison. Peter Inäbnit, returning from Carolina, is under suspicion and is thrown into prison. On the same day, March 17,1744 , eighty emigrants, who have already paid their tax $(A b z u g)$, pass by the city of Bern in a boat. Other agents (Amerika-Werber) appear, Jakob Walder of the canton of Zürich, Jacob Joner of Basel, and others. Reports having appeared in newspapers that many thousands of emigrants had arrived in Basel ready to go to America and Nova Scotia, Bern requests Basel, Zürich, and other cantons, on June 26 , to suppress such newspaper reports (whether true or false). Similarly a French paper of Bern is rebuked in $175^{\circ}$ (February 26), for publishing an article on Carolina and Pennsylvania, "where people make their fortunes." In the same year, after a group from the Oberland has succeeded in egtting a ship at Yverdun to take them over the lake, emigrants are thenceforth forbidden to take ship at this point. Letters are constantly searched for and confiscated; in 1753 the bearers of letters, Hans Zurflüh and Hans Wyss, are imprisoned for twentyfour hours, and then compelled to leave the country within a week.

Preachers who came to Switzerland soliciting funds for churches or Bibles, or seeking ministers for churches in America, were thought to be especially dangerous, since they could not be punished by the laws, yet their presence had the effect of enticing people to emigration. Therefore they were given the consilium abeundi and to facilitate their speedy departure, their hotel and travelling expenses (to the border) were given them. This happened to Michael Schlatter (prominent organizer of Reformed churches in America) in $175 \mathrm{I}$, and to Pastor Gasser (minister of the Reformed church at Santee Forks, South Carolina) in $\mathbf{1 7 5 5}$, who shortly after was ordered to be arrested on the charge of influencing people at Interlaken. Thus the Ratsherren of Bern had troubles unceasing in the 
attempt to keep their people at home, and even in 1766 and later complained of losing their population. ${ }^{22}$

Basel felt the pressure of emigration immediately because of her location at the gateway of travel. She had cause to complain of emigrants arriving in a pauperized condition, waiting to be transported. $^{23}$ A large number of emigrants were examined as to the causes of their leaving,$^{24}$ the most common reasons given being poverty, lack of employment, and failure of crops, while the hope of bettering their condition, or making their fortunes appears very seldom. The government of Basel commonly allowed emigrants to pass on, though vigorous efforts were made to discourage wholesale emigration. As early as $\mathbf{7} 335$ difficulties were created for emigrants who wished to sell their property (Vergantung, or Ganten); the ten per cent. $\operatorname{tax}^{25}$ also, and an additional sum for manumission in the case of those in bondage, were exacted, except that those whose possessions amounted to less than one hundred pounds ${ }^{26}$ were released from all payments. Many there were who had not a penny, which circumstance is also faithfully recorded in the official lists, ${ }^{27}$ sometimes with a spark of unconscious humor, as: Hans Jacob Märcklin from Dürnen has I wife, 4 children, and otherwise nothing (sonst nichts). Martin Gass from Rothenflue has I wife, 8 children, and nothing more (weiter nichts). The same list reports that: Hans Rudi Erb from Rotenflue is unmarried, has a bad face, and I 30 pounds worth of property. To avoid the tax or for other reasons many emigrants left their homes in secret, leaving behind letters to their friends, or sending them regretful notice of their departure after having crossed the border. These are referred to as Heimliche Emigranten in the records of Basel. ${ }^{28}$

The decrees of Basel, finally forbidding emigration to America, resemble those of Zürich and Bern. The one of 1749 , printed in full among the Documents ${ }^{29}$ accompanying this article, prohibits the securing of an inheritance by anyone who has left the country; the emigrant is to be considered as "dead," and bereft of rights. This

${ }_{22}$ The subject may be followed in detail by consulting the Ratsmanuale, in Guide, pp. 40-53.

${ }^{23} \mathrm{Cf}$. Guide, p. ror, etc.

${ }^{24}$ See Documents, D, I and 2.

${ }^{25}$ Cf. Kaspar Hauser, "Ueber den Abzug in der Schweiz," in Jahrbuch für Schweizerische Geschichte, hrg. auf Veranstaltung der Allgemeinen Geschichtsforschenden Gesellschaft der Schweiz, Bd. XXXIV. (Zürich, 1909).

${ }^{26}$ The value of the pound, Basel currency, was about two francs.

27 See Documents, D, I.

${ }^{28}$ For a specimen of such a letter, see Documents under B, no. 4.

${ }^{29}$ See under Documents, E, r. 
mandate was renewed in $177 \mathrm{I}$, and an additional decree was published in 1773, aimed particularly at crafty emigrant agents, attempting to collect inheritances for friends in America. The word Neuländer is here ${ }^{30}$ used for Werber, agent. The petitions and records at Basel show that the high tide of emigration at that city occurred between 1734 and $175^{2}$; another wave started about 1767 and lasted until $\mathrm{I773}$, when it was interrupted by the Revolutionary War. Emigration started again, though feebly, in $\mathbf{I} 786.3^{31}$

The archives of Schaffhausen give evidence of emigration from that quarter in large numbers between 1734 and I 748. The Chronicle of the city (Harder Chronik) refers to this emigration several times, e.g., September 8, I738:

In June many poor people from neighboring districts, notably Merishausen and Reiat, emigrated to North America. When then also some [of our] subjects at Rüdlingen and Buchberg made the unseasonable resolve to leave their fatherland and travel to far distant lands, and thus in thoughtless manner expose themselves to great discomfort and extreme wretchedness with repentance coming too late, the government "stepped in" and forbade emigration on penalty of the loss of land-right.

The cantons of Aargau, Solothurn, and especially Graubünden also furnished a quota of emigrants in the eighteenth century, though the records have been lost. There was emigration also from Luzern and the forest cantons, though the emigration from Catholic was smaller than from Protestant cantons. Interesting plans were proposed from time to time, to employ those desiring to emigrate in some remunerative industry, or to use the undivided land (Allmend) or the forests (Hochwald) for the benefit of the hopelessly poor. Almost without exception, however, these plans were never put into execution, and in the very few cases when they were carried out, they lived only a very short time. ${ }^{32}$

The archives of Switzerland throw new light on the character and methods of the emigrant agent. Owing to the severe penalties placed upon the trade, he appears as a far more subtle individual than the traditional Neuländer. The latter (so he is generally depicted), having failed as a colonist and finding "emigrant-hunting" a far more profitable means of livelihood, affected the appearance of wealth, with his conspicuous attire and heavy gold watch and

${ }^{30}$ See under Documents, E, 2.

${ }^{31}$ See Guide, pp. 101-107.

${ }^{32}$ Cf. Dr. E. Lerch, Die Bernische A uswanderung nach Amerika im I8. Jahrhundert, separate print from the Blätter für Bernische Geschichte, Kunst, und Altertumskunde, Jahrgang V., Heft 4, December, 1909, pp. 19-31. Cf. also Bern, Responsa Prudentum, Guide, p. 55. 
chain, and loudly proclaimed tales of easily acquired wealth, bearing forged letters in witness of his claims. Such a figure may have existed and flourished at the seaports of Europe and America, but he could not have survived longer than a day in the upper Rhine country or in Switzerland. Watchful eyes would have been upon him, and the reward would have been collected for his capture twice before he could have earned a single fee for bringing an emigrant to port. The successful emigrant agent was a person of an entirely different description, shrewd, tactful, inconspicuous, denying any purpose of his visit, except to collect a debt or inheritance for a friend in America. He was careful not to arouse suspicion, and gave information only when asked for it. A good view of his methods can be derived from the records at Bern and Basel of trials (Verhöre) of persons suspected of enticing emigrants. Two of these are of particular interest, the examination of Peter Huber at Basel and Bern in $\mathbf{1 7 4 2}$, and of Peter Inäbnit at Bern, in I744. The verbatim reports of these trials, found in the archives of Bern and Basel, are published here for the first time, accompanying this article. ${ }^{33}$

Peter Huber was taken captive at Basel on the request of Bern. The examination at Basel reveals that he was a native of Oberhasli in the Bernese Oberland, about thirty years of age, and by trade a shoemaker. He was on his way back to Carolina, accompanied by his wife and two children, whom he had come to fetch the foregoing summer. One daughter had gone with him to Carolina on his first trip, about eight years before (I734), and she had remained in Carolina. To the question, whether he had any other travelling companions, he answered that his sister was bringing his baggage for him, and another woman, Barbara Horger, expected to go with him to Carolina. He denied knowing aught of the group of emigrants who had arrived at Basel, and affirmed positively that he had not urged anyone to make the journey with him. A number of emigrants at Basel were examined, ${ }^{34}$ one of whom declared that he had been enticed by Huber, but that now, yielding to the advice of the authorities, he would prefer to remain. All ten others denied that Huber had put the idea into their heads, and all but two insisted on being allowed to go. So far no damaging evidence was brought against Huber. He was then taken to Bern in custody, and subjected to a more searching trial. The questions show that a body of facts had been collected against him that might indeed

${ }^{33}$ See Documents, A, I, 3, 4 .

${ }^{34}$ See under Documents, A, 2. 
arouse suspicion, but such was Huber's skill in answering them, that he could not be convicted on the first examination. Some of the questions and answers were as follows:

Q.: Could he [Huber] deny, that he had desired to take some people away with him?

A.: He had desired to take no one away, except his șister, and the foreigner Jacob Lanu, who had worked in the mines for seven years. The latter had frequently approached him asking to be taken along, but he [Huber] had refused, saying that such a thing was prohibited. The inspector of the mines had, however, told Lanu that, being a free man, he could go wherever he wished. [Lanu was not a Bernese subject.]

When Lanu was confronted with Huber, contrary to his previous statement, he declared that Huber had not enticed him, but that he wanted to go on his own free will.

Q.: Did not Peter Scherz of Aeschi come to him [Huber] at Unterseen, and ask, whether a weaver could with wife and children make a living in Carolina?

A.: Scherz had come to him at Zollbrück, crossed the lake and spent the night with him, but that he [Huber] had told him there were enough weavers in Carolina, moreover that Scherz had not enough money for so long a journey. Subsequently he had received two letters from Scherz, which he had not answered.

Q.: Whether he did not urge Hans Aebiger to go to Carolina?

A.: Aebiger had come to him and asked how the hunting was in Carolina? Upon this he had described the country. Aebiger also asked him about a gun, which Aebiger offered him.

Aebiger affirmed, when examined, that Huber had awakened in him the desire to emigrate, and especially in his wife, who left him no peace about it, but that he was willing to remain, rather than incur the ill-will of the government. Several others also were examined. ${ }^{35}$ Those who decided to remain, perhaps in order to better their chances with the authorities, threw the blame on Huber, while those who were firm in their resolution to go, exonerated Huber from any attempt to entice them.

After a number of other questions on individual cases, the court declared that it was very plain that Huber had enticed the poor people by praising Carolina; he should therefore confess in order to secure more gracious treatment. Thereupon Huber boldly affirmed, that he had spoken nothing but the truth; he had given up his citizenship and land-right, and had enticed no one; no person would

135 See under Documents, A, 3 (at the close). 
dare to confront him with such a charge. Huber was remanded to prison.

A few days later a slip of paper was discovered, which Huber had thrown out of the prison window, and on which he told those who were still minded to travel with him to Carolina, to go and tarry for a while in the neighboring Neuchâtel; as soon as he was set free he would come to them and take them along with him to Carolina. Upon this new evidence Huber was tried again. The examiners skillfully concealed their discovery at first, in the hope of extracting more information, and cautioned him to adhere strictly to the truth.

Q.: What route had he [Huber] taken on his previous journey to Carolina?

A.: By way of Burgundy [i.e., Neuchâtel-Besançon], and France to Calais.

Q.: Why then did he take a different route this time, and go by way of the Brünig Pass, Unterwalden, Basel?

The question was a critical one, for there was suspicion, that he was taking people from the Oberland by the mountain route to Lucerne, and thence to Basel, keeping them out of the jurisdiction of Bern. Otherwise they would have to come by way of Thun and pass Bern, on the way to Neuchâtel.

A.: He had intended to take his former route, but in order to avoid suspicion, and being followed by emigrants, he preferred the other route.

Q.: Whether he did not know that people had gone ahead to Basel to await him there?

A.: No, he had heard that one or another had gone down from the Oberland, but where they intended to go he did not know, except in the case of Barbara Horger, who accompanied him.

Q.: He should tell truthfully, whether this was not a plan, to meet at Basel, and then go together to Carolina?

A.: No! He had nothing to do with those people, for he expected to take his usual route from Basel by land to Calais, while those people were going to take the Rhine route, and a ship had already been engaged for them.

New evidence was now brought against him; his baggage had been examined and a most interesting device for concealing letters was found therein.

Q.: Was he [Huber] not in possession of a wooden vessel [hölzernes Geschirr], the top of which would hold drink, and the bottom of which could be used for concealing letters? 
A.: Yes, such a one was made for him by Hans Roth in Carolina, and could be found in his baggage.

Q.: Had he not given Landsvenner Sterchi ${ }^{36}$ at Zollbrück a ring and seal, by which he could recognize letters coming from him?

A.: No! He had, however, brought with him a letter of Peter Zaugg in Carolina to Sterchi; he knew not if anything of the sort were contained therein.

Q.: Since he [Huber] had thus far been very obstinate in denying answers to questions, at the same time had assured the court, that he would gladly confess all that was true, they wished now to see how earnestly he loved the truth: Did he not, the day before yesterday, throw [from his prison window] toward a woman of his part of the country [Oberland], a piece of paper, on which was written, that those that still had a desire to travel with him, should go to Neuchâtel and tarry there a while, that he hoped his case was not so bad that he might not soon be free, and when at liberty he would come and in passing take them with him, they would then directly be in Burgundy, and could pass on unhindered?

A.: At this question he seemed altogether terrified, looked about him to one side and another, and for some time did not know what to say, and the tears came to his eyes. Finally he answered: Yes! He could not deny this; he had thought, that when once free and finding these people outside of the jurisdiction of Bern, he could take them along without doing any wrong, but he confessed being grievously at fault in this, and humbly besought God's and Their Graces' pardon. [Act. March 2I, I742.]

Huber was taken back to prison, but was evidently set free soon after, and banished forever, perhaps under threat of the death penalty if he were caught attempting to return. We learn from the testimony of Peter Inäbnit, two years later, that Huber arrived in Carolina with a small number of emigrants, perhaps with more than the examinee was willing to state.

Peter Inäbnit (Imäbnit, In Äbnit, or Im Äbnit), brought to trial in $\mathbf{7 4 4}$, was not so fortunate. He lost his life in the venture, though equally clever and perhaps better instructed, for Inäbnit left Carolina after Huber had returned, and probably received directions from him. Peter Inäbnit had left Switzerland in 1734 with his parents and their children, when he was still under age. He was therefore privileged to return to his home in Grindelwald, and could lawfully remain there if he wished, for the law debarring an emigrant from all rights did not apply to his children leaving under age. It

${ }^{36}$ Landsvenner (Bannerträger) Sterchi was a friend of emigrants; see his. name mentioned in a letter, Documents, C, 2. 
was very clever on the part of Inäbnit to declare that he wished to live in Switzerland, and not return to Carolina. He was about twenty-five years of age in 1743 , when he reappeared in the Oberland, to collect some money from a relative in his native town of Grindelwald. He was observed moving from place to place, notably in the districts of Hasli and Interlaken, whence most of the emigrants had always come. He also visited Reichenbach (located near Bern on the peninsula of the river Aare), then the seat of the English envoy. He had been seen surrounded by large crowds of people, especially on Sundays, and he was asked all sorts of questions by them, but was moderate in his speech. He was also reported to have brought letters from Carolina. For all of these circumstances he was under suspicion, and was soon brought before a court for examination. ${ }^{37}$

Many a prisoner fell a victim to his inquisitors on the initial question, why have you been taken captive? Not so, Peter Inäbnit. He expressed ignorance and surprise.

Q.: Why was he still remaining in the country, though his business must have been settled long ago?

A.: He expected to remain in Switzerland. In Carolina he had lived nine years, and suffered from illness all but the first two, for that reason he did not like the country, and did not expect to return.

Q.: There were reasons to doubt this, for it was known, that he had come with a very different purpose; he should tell squarely, whether he had not come to entice some of his countrymen, and engage them to go with him to Carolina?

A.: God forbid! He had not come to take anybody with him.

Q.: How could he explain, that wherever he appeared in the Oberland, crowds of people gathered about him, and since then it was found that a great many desired to emigrate?

A.: Of that he knew nothing, but he could tell no other reason, than that they wanted to hear something about how their relatives in Carolina were getting along.

Q.: Had he not praised the country, or talked about it to anyone?

A.: To many who asked out of curiosity, he had spoken about the nature of the country, but no one could prove, that he had advised anyone to go there.

Q.: Whether he did not write a letter to the English envoy with this intention?

A.: At this he was somewhat taken aback. Finally he confessed having written the letter, ${ }^{38}$ saying he never intended delivering it to the

${ }^{37}$ See Documents, A, 4.

${ }^{38}$ The letter in question has survived; it is printed in full under Documents, A, 4. It reported to the English resident at Reichenbach, that there were about 
envoy, but merely wished to satisfy those who urged him to do so. No sensible person, said he, would ever think, that anything could be accomplished in this way.

Q.: Would he deny having been at Reichenbach, in order to speak with the envoy?

A.: To be sure, he had been there, but had had no audience with the envoy. ${ }^{39}$

Q.: Whether he did not, at Grindelwald, station himself in the churchyard on Sundays, and commend Carolina to the people?

A.: He never staid long in the churchyard, but many people came to him in the inn, but he told them nothing more than what they asked about Carolina.

Q.: Whether he had not brought letters from Carolina, that undoubtedly gave a favorable enough account of the country?

A.: Yes. Eight letters, one to Grindelwald, and seven to Oberhasli.

Questioned about the letters in another examination, he said he knew not the contents, except that Christen Brauen wrote to his father, that he had arrived safely, but not having had sufficient means, he had been obliged to serve for four years. People in Carolina, Inäbnit declared, had tried to overload him with letters, but he had refused except in behalf of his nearest friends, because only trouble came of it.

Q.: Who had told him to write to the English envoy?

A.: He could not tell, but he had been urged from many quarters.

Q.: Why did he wish to speak to the English envoy personally?

A.: He wanted to offer his services, since he had heard that the English resident desired a servant who could speak English. But he did not succeed in seeing him.

Q.: What had he told the people about Carolina, making so many of them anxious to go there?

A.: He had not said anything specially about it, except in answer to questions; moreover, he had neither praised nor blamed the country, but of course told them what the conditions were, and that over there as here, whoever brought nothing was in a bad way, and although as a carpenter he had earned 15 batzen a day, he did not wish to go back, because he could not pull through very well.

200 persons ready to go to Carolina, if the Hon. Ambassador would open his generous hand, but that most of the people were poor, and some that were not did not know how to get their property away. Some had small children and did not know how to go about the matter of the journey. They wanted also to know something about the period of service.

${ }^{39}$ It would have been very unwise for the envoy to receive a person offering to violate the laws of the country to which he was accredited. 
Q.: Had not in the preceding year Peter Huber taken people to Carolina? [An attempt to connect him with the convicted agent.]

A.: There were nine or ten persons who arrived with him, but he [Huber] could not have derived any benefit therefrom, especially since some, for their travelling expenses, had to serve those who had released them from the ship.

Q.: He should once for all tell the truth, and say, whether he had not been sent expressly to bring people into the country?

A.: No, he had merely wished to see his fatherland again, and remain here, or in Germany.

The document goes on to say, that after the prisoner, in spite of expostulations, threats of torture, and confrontation with the executioner, had refused further statement or confession, he was taken up to the torture-chamber and once more vehemently urged, and threatened with the application of torture-nevertheless he adhered firmly to his previous statements, viz., that he had not come to entice anyone to go to Carolina, that he did not know what was contained in the letters he brought with him, that he himself did not intend to return to Carolina, and no one could charge that he had lured anyone to go, on the contrary he had rather advised against than in favor of emigrating. For the rest he realized that he was in the power of the high authorities, they could do with him whatever they wished, however he begged that they graciously give him his liberty. Upon that he was condemned to stand in the stocks, and then banished forever. This was in February, I 744.

In spite of his cleverness, courage, and firmness, Peter Inäbnit failed, for he lacked the quality of caution. He made the mistake of writing too many letters, dangerous instruments, for they could easily get into the wrong hands. Instead of leaving Switzerland at once, he was discovered at Basel during the following month, and brought once more to Bern. There he was forced to confess that he had written letters to Hans Nägeli, Christen Brunner, and Hans Müller, instructing them how to go about preparing for the journey to Carolina. He claimed that he was greatly urged to do so, was under the influence of drink, and believed he was doing no wrong, since he was banished anyway (not a convincing argument). $\mathrm{He}$ confessed having written also to Grindelwald for the money which was coming to him, and to his cousin Christen Feller, near Thun, inviting him to go with him to England to visit a relative. Concerning the letter from Philip Wild of Rotterdam, ${ }^{40}$ he explained

${ }^{40}$ This letter to Peter Inäbnit was captured, according to a record in the Ratsmanuale of Bern, February 20, I 744. It seemed to prove that Inäbnit had instigated about 70 families to emigrate. On this evidence he was ordered to be arrested again. See Guide, p. 47. 
that the blacksmith Jacob Ritschard ${ }^{41}$ had for several years back planned to go to Carolina, and had requested him to write for information to Rotterdam, which he did, asking Wild to reply to Ritschard. For himself he had done nothing, and was not minded to go back to Carolina, and no one could bear witness against him, saying that he had enticed anyone. Therefore he prayed for his release. This was on March 27, I744.

The court sent Peter Inäbnit back into confinement. His prison was one of those picturesque old towers still standing in the city of Bern, the one still known as the Käfigturm (the cage-tower, i.e., prison-tower). The prisoner had many friends, and they were willing to aid him. They brought him food and wine; a tool for boring was smuggled in to him and a rope, by which he planned to let himself down and make his escape. Unfortunately an accident prevented the successful issue of his daring venture. The rope seems to have been securely fastened, but either the rope broke or the prisoner lost his hold. He was discovered lying bleeding and unconscious at the base of the tower. The abettor of emigration was carried to a neighboring inn, but never recovered speech or consciousness from after nine in the evening, when he was found, until seven in the morning, when he died. No sympathy was wasted on him by the rulers of Bern. "Owing to clearly proven and partly confessed crimes of the deceased, the body was ordered to be buried under the place of public execution," thus abruptly ends the chronicle of the career of Peter Inäbnit. ${ }^{42}$

Both men, Peter Huber and Peter Inäbnit, will be pardoned for their crimes by the American historian. Though dangerous to the interests of their home governments, they were indispensable helpers in the building up of the new colonies, of a new people. They were unselfish in the main, aiding the poor to a condition of self-support, and their friends to social and economic betterment. There were many agents who were not of as high character, e.g., Jacob Joner, whose selfishness and greed led him to attempt to acquire the inheritance of a fellow-countryman, as his trial at Basel in $\mathbf{1 7 5 0}$ proved. ${ }^{43}$ There were agents good and bad, and their activities

${ }^{41}$ Ritschard was examined with others of the Huber group. As stated by Peter Inäbnit, Ritschard had for several years been anxious to go to Carolina. He denied that Huber had influenced him, but that a book on Carolina had started his interest. Ritschard claimed to have relatives in Holland (Leiden), whom he wished to see and from whom he expected assistance. See Documents, $A, 3$ (end).

42 In Documents, A, 4, at the end, will be found statements of fellow-prisoners concerning Inäbnit, who is given a good character by them. Their accounts add a touch of intense realism to the tragic close.

${ }^{43}$ See Guide, p. 112 ff., etc. 
were far more hidden, their methods far more subtle than has generally been supposed.

Next to emigrant agents, letters from colonists with favorable comments on the new country were considered the greatest danger. Letters of this kind as early as I 7 I I have survived, ${ }^{44}$ and these were probably not the first. ${ }^{45}$ These letters are typical for most that follow, telling of the agricultural wealth, the opportunities for cattleraising, the liberty of body and soul, the high wages, also the hard work but sure returns. They do not conceal the perils of the sea, the loss of life, the scarcity of spiritual guidance, comforts, and pleasures, but all these drawbacks fade away in the presence of the heroic pioneer spirit, the colonial optimism, that pervade the letters. The example of one successful pioneer has greater force than the discouragement of half-a-dozen that fall by the wayside. The effect of such letters was not fully realized until the great waves of emigration set in during the early thirties of the eighteenth century. Then all possible causes of the "emigration-fever" were searched into, and letters were discovered to be a disease-breeding germ, if not the responsible bacillus. Measures were at once taken for their capture and extermination, letters were hunted and kidnapped, the bearers and recipients were punished if they refused to give them up. A few illustrations of governmental action will suffice. In I 737 Hans Georg Striker wrote a report on Carolina for Lieutenant Rubi in Thun; this letter was ordered to be seized and laid before the government of Bern. ${ }^{46}$ In 1742 Peter Stoker's letters from Carolina were demanded of him. In the same year a letter from Carolina addressed to Daniel Kissling of Wattenwyl was ordered to be surrendered by the Ratsherren of Bern. On March 4, I 744, the police of Bern were instructed to prevent the luring of emigrants by means of letters; it was the same day on which Bern asked Basel to take Peter Inäbnit prisoner. A fine of thirty pounds was to be inflicted on anyone who would not surrender such a letter without delay. On April 29, I752, letters from Pennsylvania were ordered to be opened and copied. Anything unfavorable to the

${ }^{44}$ Cf. "Copia Underschiedlicher Brieffen auss Nord Carolina" (I 7 I I ), included in the article: "The Graffenried Manuscripts," German American Annals, n. s., vol. XI., nos. 5, 6, September-December, 1913. The letters are here printed in full.

${ }^{45}$ The earliest Swiss settlers in America were probably some who had left their homes in the seventeenth century for the Palatinate, and subsequently joined groups of Palatines emigrating to America. From such, letters may have been received in Switzerland before I7II.

${ }^{46}$ Bern, RM., CLIII. 40-443. 
colonies should be published in the next issue of the annual calendar (Der Hinkende Bote). ${ }^{47}$ The policy was widespread of suppressing the favorable passages of letters and publishing whatever was damaging. Thus one of the most critical, in parts vituperative, epistles, ${ }^{48}$ one written by a disappointed woman, Esther Werndtlin, the widow of Pastor Göttschi (who died shortly after arriving in Philadelphia), was printed and widely circulated by Zürich and Basel. ${ }^{49}$ Basel ordered (April 2, I738) that copies be sent to all the country districts, to the preachers in every parish, and be made known to every subject desirous of emigrating to Pennsylvania. The number of letters with tidings of fortunate experiences in America was undoubtedly very much greater, judging by the mass of letters contained in the state-archive of Basel. Most of these unquestionably were confiscated letters, ${ }^{50}$ held in the archives to prevent their circulation. It is not surprising, therefore, that Peter Huber (the country-folk of the Bernese Oberland were noted for their cleverness) carried letters in the false bottom of a drinkingvessel, specially constructed for the purpose of concealing written messages.

The policy of suppressing favorable news was also forced upon the newspapers. On October 8, I736, the Council of Bern gave the following order: "Since the Avis-Blättlin [Intelligencer] has recently brought an article on Carolina, the editor is directed in the future not to publish any more reports on Carolina and the condition of the emigrants there. In any case nothing favorable about them shall be printed." 51 On February 6, I738, the Avisblätter of Bern and Lausanne are commanded not to publish any of the reports coming from the neighboring Neuchattel, in view of the propaganda coming from there. ${ }^{52}$

A further danger existed in the numerous books and pamphlets descriptive of the American colonies. The earliest actually received encouragement from Swiss governments, because information was desired. Thus Kocherthal's report, and Ochs's Amerikanischer Wegweiser (I7II) were welcomed, and the latter rewarded. But

${ }^{47}$ See Guide, pp. 46-49, etc.

${ }^{48}$ This letter dated Philadelphia, November 24,1736 , is reprinted among the documents accompanying this article, see Documents, C, I. Some of the letters published in the Hinkende Bote of Bern, have also been included, see Documents, C, 2.

${ }^{49}$ Cf. Guide, pp. 30, 103, etc.

${ }^{50}$ A number of these appear in print for the first time among the accompanying Documents, see B, $1-6$.

${ }^{51}$ Bern, RM., CLII. 224.

${ }^{52}$ Ibid., CLVII. I22. 
though at that time emigration was not feared, even these did not fail to arouse a protest, as in the booklet: Das verlangte und nicht erlangte Canaan bei den Lust-Gräbern . . . absonderlich dem . . . Kocherthalerischen Bericht wohlbedächtig entgegen gesetzt (I7II). Later it became the general practice to reply to every book that gave a favorable account and gained a circulation. Thus the eulogistic account of Carolina published in 1734: Der nunmehro in der Neuen Welt vergnügt und ohne Heim-Wehe lebende Schweitzer, provoked the equally curious book: Neue Nachricht alter und neuer Merkwürdigkeiten, enthaltend ein vertrautes Gespräch und sichere Briefe von der Landschafft Carolina und übrigen Englischen Pflanz-Städten in Amerika (1734). The latter was in effect a denial of the one that went before, and was widely circulated by the governments to counteract the influence of its predecessor. Another booklet adopting the catching dialogue form of the Neue Nachricht and equally impressive in its warnings against the American colonies, was Der Hinckende Bott von Carolina, oder Ludwig Webers von Wallissellen Beschreibung seiner Reise von Zürich gen Rotterdam (I735), suggested by the unfortunate experiences of Pastor Göttschi's group of emigrants from Zürich. The Neu-Gefundenes Eden (1737) was followed in the same year by Christholds Gedanken, bey Anlasz der Bewegung, welche die bekannte Beschreibung von Carolina, in Amerika, in unserm Land verursacht. In this a Kingdom is named superior to the New Eden, toward which there is a beautiful voyage without sea-sickness, where there is eternal peace instead of wars, and where there is a great and just king, better than any ruler on this earth-and the reader is cautioned not to lose this Kingdom, which he might do by yielding to the seductions of the New Eden. ${ }^{53}$

The large amount of attention given to emigration, and the severe restrictive measures adopted by the Swiss governments of the eighteenth century, indicate that they were not contending for a mere abstract principle, but were dominated by the fear of an everpresent danger. It was not to them a question of losing a few hundred people annually, but of depopulation of whole country districts, as was threatening in the case of Eglisau in the canton of Zürich, or Oberhasli in the highlands of Bern. Had this panic fear sufficient foundation in fact? This question is difficult to answer, owing to the lack of accurate statistics. In the decade from 1753 to 1763 , which was a period of only moderate emigration, about

${ }^{53}$ For a list of books and pamphlets belonging to this eighteenth-century emigration period, with full titles, see Guide, pp. 29-3I, etc. 
I0,000 persons left the canton of Bern, 4000 of whom were men entering foreign military service, and 6000 men and women emigrating to other countries. ${ }^{54}$ The loss of Iooo persons annually was at least appreciable. The fact also, that recruiting in foreign regiments was constantly draining the country of men, undoubtedly made the governments more eager to stop the leakage caused by emigration.

The only accurate statistics which the writer was able to find in the Swiss archives, bearing on the question of the number of Swiss who came to the American colonies in the eighteenth century, was a carefully compiled list of emigrants from the canton of Zürich during the years $1734-1744 .^{55}$ The list furnishes names, with dates, home districts and destinations, and claims to be complete. The total number it records is 2300 . This one reliable source furnishes a reasonable basis for an estimate of the total emigration to America in the eighteenth century. If there were 2300 names of recorded emigrants from the canton of Zürich, we must add about two hundred more for secret migration (those leaving without permission); this would give Zürich 2500. Since the canton of Bern was more populous, and emigration very prevalent, we may assign to Bern the number 300o. Basel in proportion to her population might be given I500. Other cantons whose archives contain most evidences of emigration in the eighteenth century are: Aargau, Schaffhausen, Graubünden, and Solothurn. Together they probably equalled Zürich in population, therefore the number 2500 would fairly represent their emigration. The remaining cantons, mostly Catholic, did not have as large an emigration in the eighteenth century, if we can trust the fact that very few records of emigration from those quarters appear. The number 2500 would perhaps more than do them justice, though the population represented is more than three times that of Zürich. This would give a total of 12,000 emigrants for all of the Swiss cantons during the period I734-I 744. Now, these eleven years represent the high tide of Swiss emigration to the American colonies. It is not likely that the total emigration for the eighteenth century was more than twice this figure, judging by the records in the archives. It is the writer's opinion, therefore, that the emigration from Switzerland to the American colonies in the eighteenth century amounted to something like 25,000 persons,

${ }^{54}$ Cf. Dr. E. Lerch, Die Bernische Auswanderung nach Amerika im I8. Jahrhundert, p. $3 \mathrm{I}$.

${ }^{55}$ Staatsarchiv, Zürich, A. I74. "Verzeichnisse der Ausgewanderten nach Carolina und Pennsylvanien I734-I744." See Guide, p. 14. This is the list printed below, and here published for the first time. 
though the discovery of additional data might change this estimate to a figure above or below the one assumed.

Numerical estimates of eighteenth-century emigration appear strangely diminutive when compared with the statistics of the nineteenth century. The United States reports, running back to I 820 , show a total Swiss immigration up to I910 of over 250,000. A strong current set in about I8I6, during a period of economic depression (das Hungerjahr). The emigration from Switzerland fluctuated in the nineteenth century. From hundreds annually it rose to over 1500 in 1828 , dropped, and rose again to about 1400 in I 834; starting again strongly in 1852 with nearly 3000 , it rose to 8000 in 1854 , dropped to 4500 in 1855 , and much lower in succeeding years, until the high-water mark came in the eighties, beginning with over 6000 in 1880 , and reaching the crest in 1883 with $\mathbf{I} 2,75 \mathrm{I}$. From $\mathrm{I} 880$ to $\mathrm{I} 886$, over $6 \mathrm{I}, 000$ Swiss arrived in the United States. Recently the average has been about 3000 annually. The embargo upon emigration was removed by the Swiss cantons in the nineteenth century. Periodic conditions of overpopulation, failure of crops, and hard times, recurring in certain districts, showed plainly that, far from being a cause of fear, emigration might prove an advantage to a vigorous people increasing rapidly, yet confined within narrow borders. Complaints from seaport towns in France, Holland, and Germany, calling attention to the congregating of masses of poor people waiting to embark, and subsequently the objections of the United States to the deportation of undesirable classes, brought about a regulation of emigration from Switzerland. The policy was adopted, neither to encourage nor to discourage emigration, but to let it take its course, and to protect the emigrant against the selfishness of speculators, and the consequences of his own ignorance. The business of transporting the emigrant was left in the hands of agencies, who were required to secure a license and to obey the laws. In 1880 the Federal Emigration Bureau (Eidgenössisches Auswanderungsamt) was established at Bern to control the licensed agencies, to enforce justice and provide helpful information. This represents the modern solution of a problem so exasperating to the cantonal governments of the eighteenth century. 


\section{LIST OF EMIGRANTS TO CAROLINA AND PENNSYLVANIA, I 734-I 744}

No. I. List of those Persons, who Between I 734 AND I 744 Left the Territory OF Zürich, IN Order to Travel to AMERICA

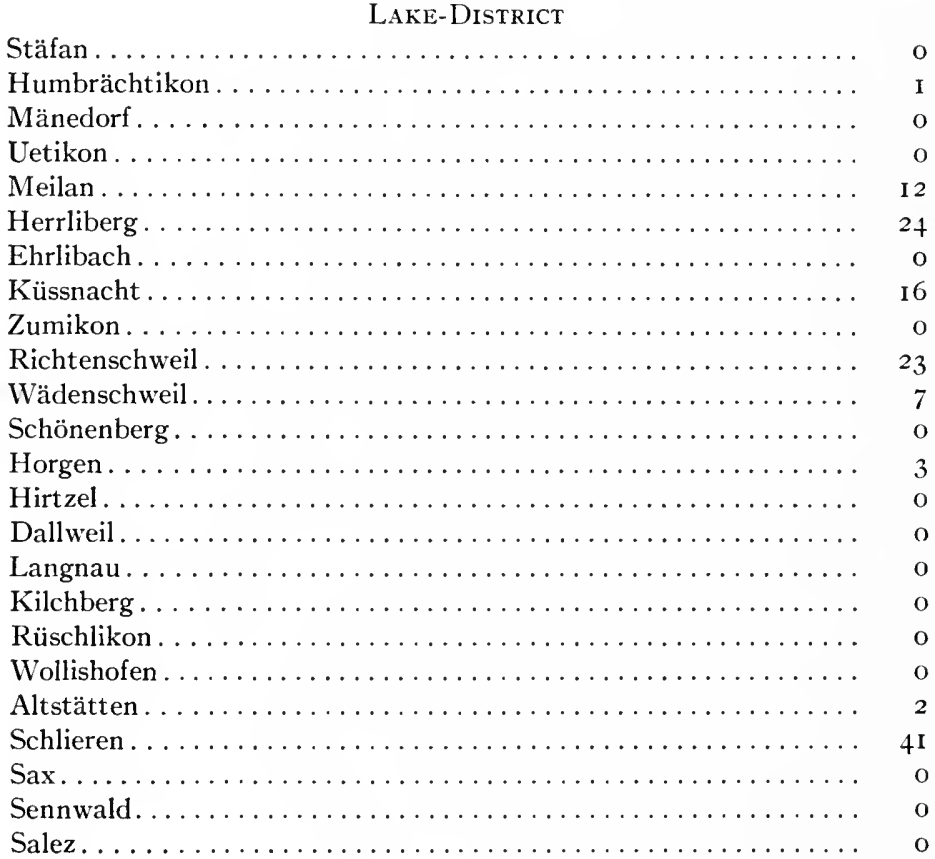

\section{FREY}

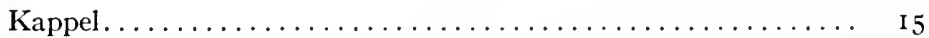

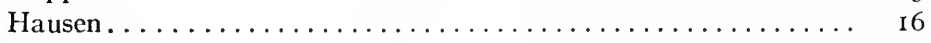

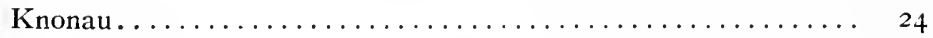

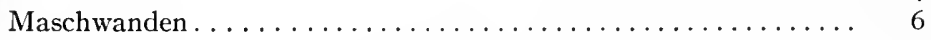

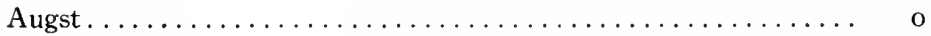

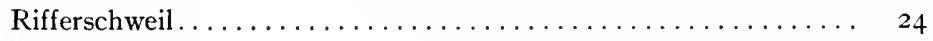

3 Metmenstetten ....................... 6

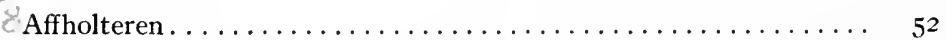

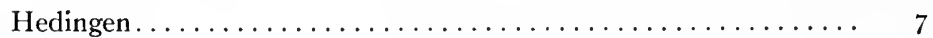

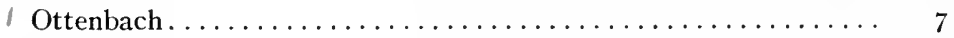

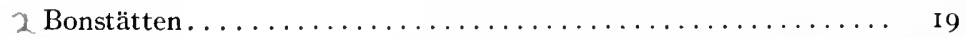

Stallikon . . . . . . . . . . . . .

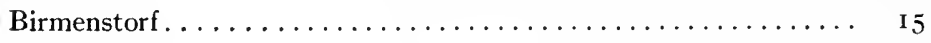

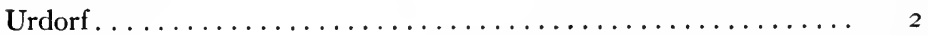

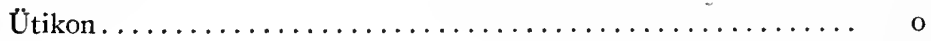




\section{STEIN}

Stein . . . . . . . . . . . .

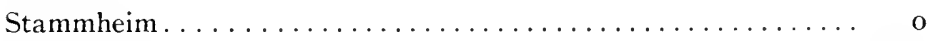

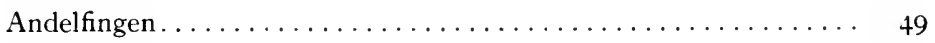

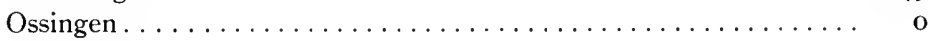

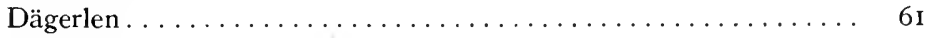

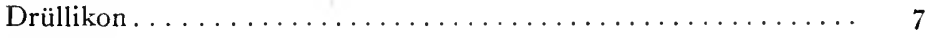

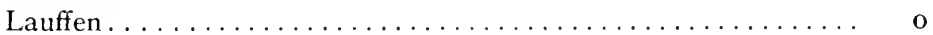

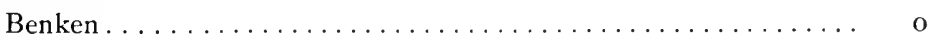

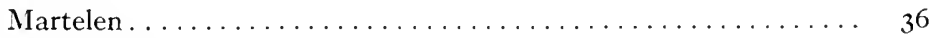

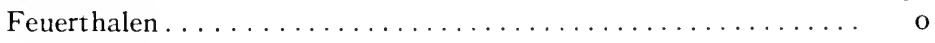

Dörfflingen . . . . . . . . . .

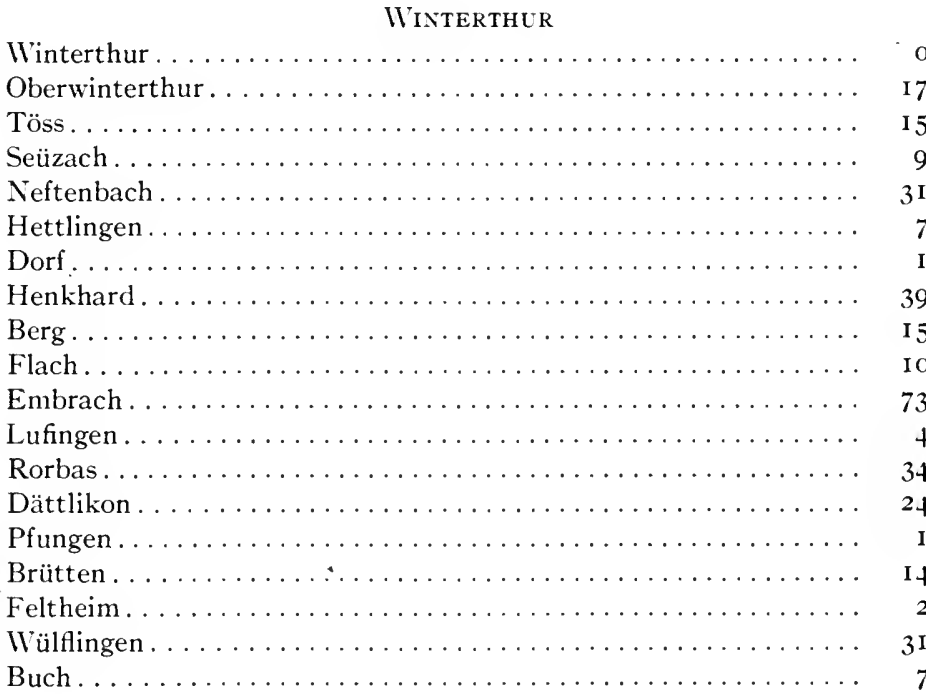

ELGG

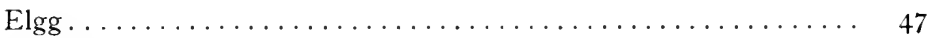

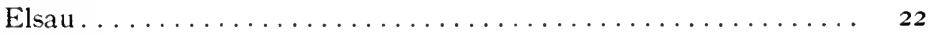

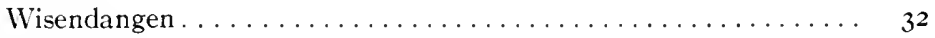

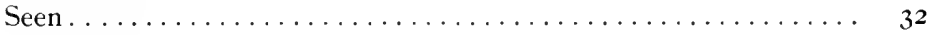

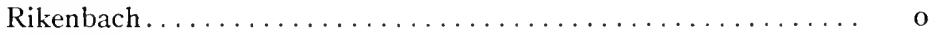

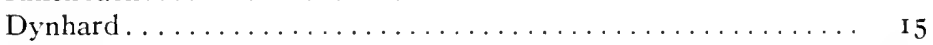

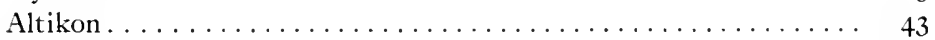

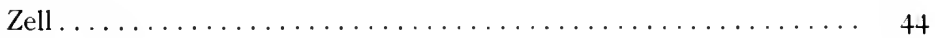

Turbenthal .............................. 2

Schlatt............................... o

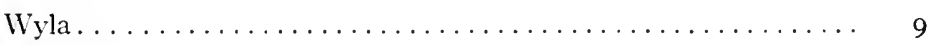

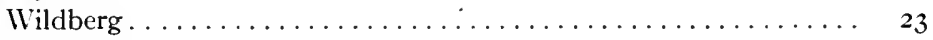

Sternenberg ....................... I5

\section{WETZIKOM}

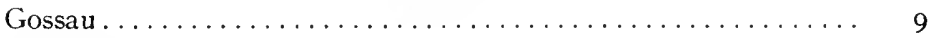

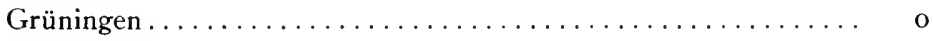

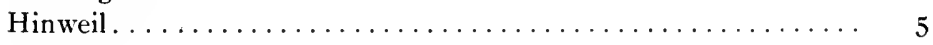

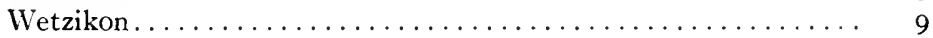




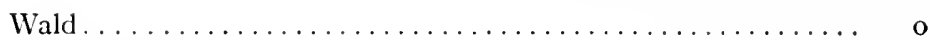

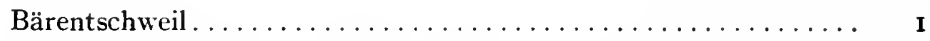

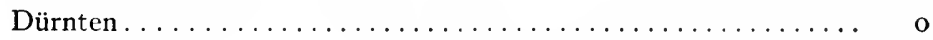

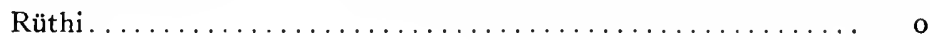

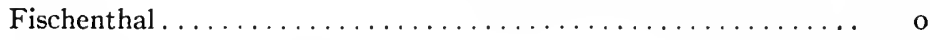

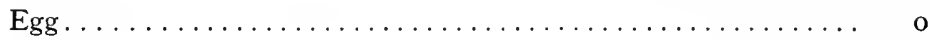

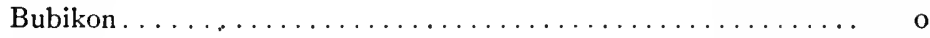

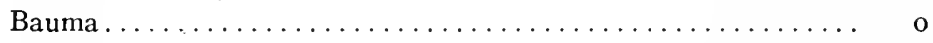

Oetweil. ......................... 4

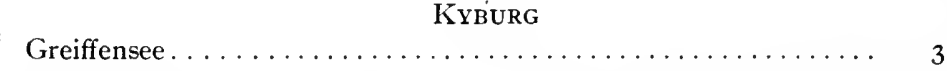

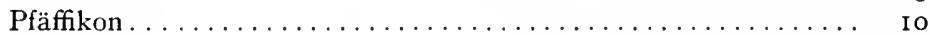

Hittnau . . . . . . . . . . .

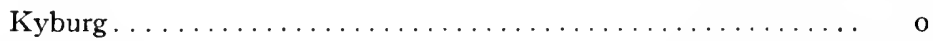

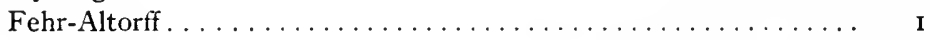

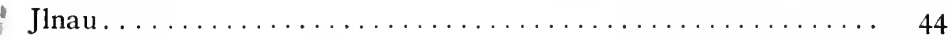

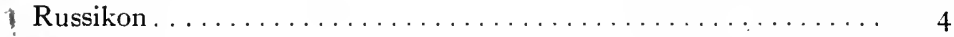

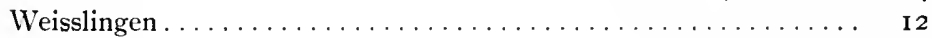

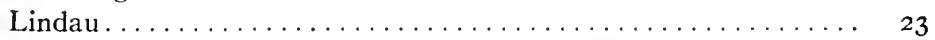

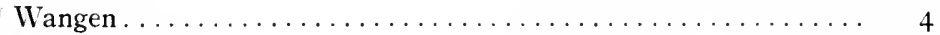

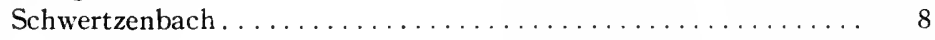

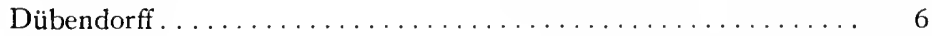

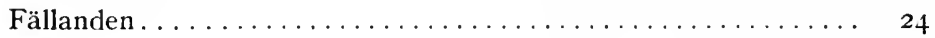

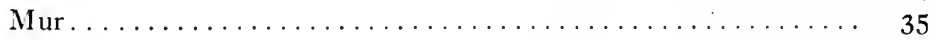

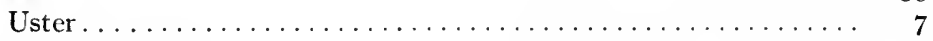

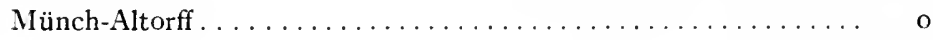

Volketschweil ..................... I 8 C

REGENSBERG

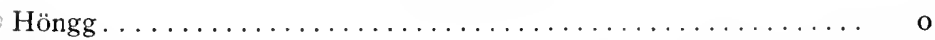

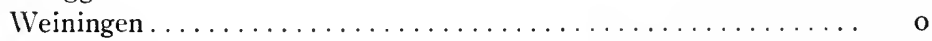

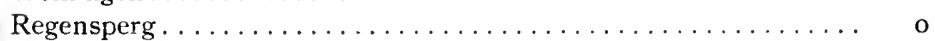

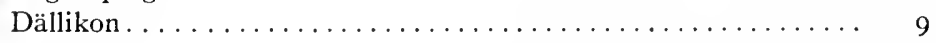

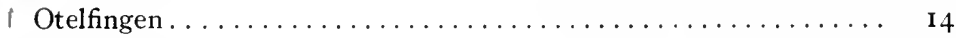

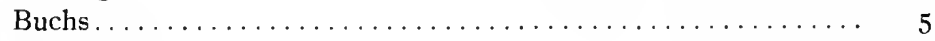

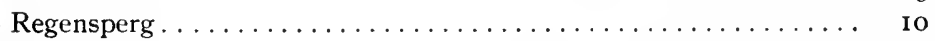

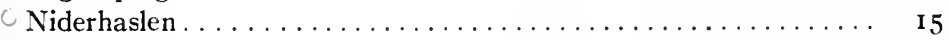

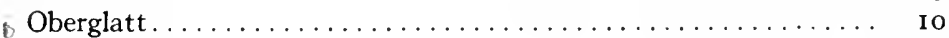

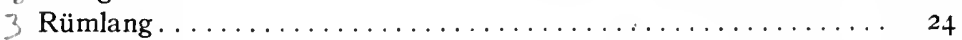

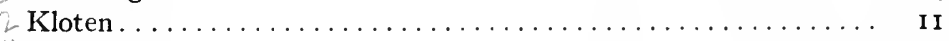

4 Basserstorf . . . . . . . . . . . . . . . . . . . . . . 69

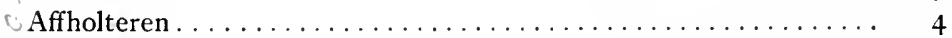

Dietlikon .......................... 8

Eglisau

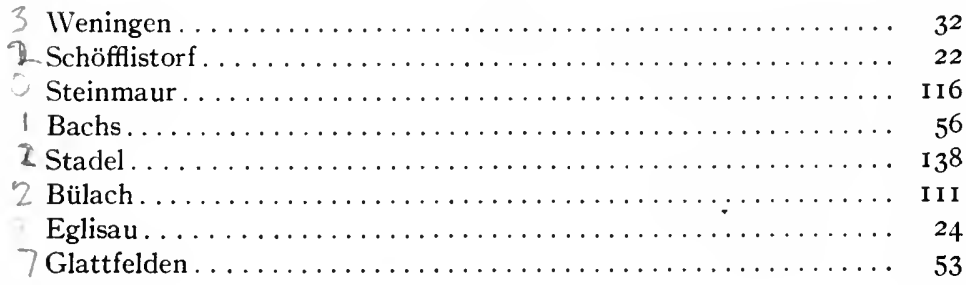



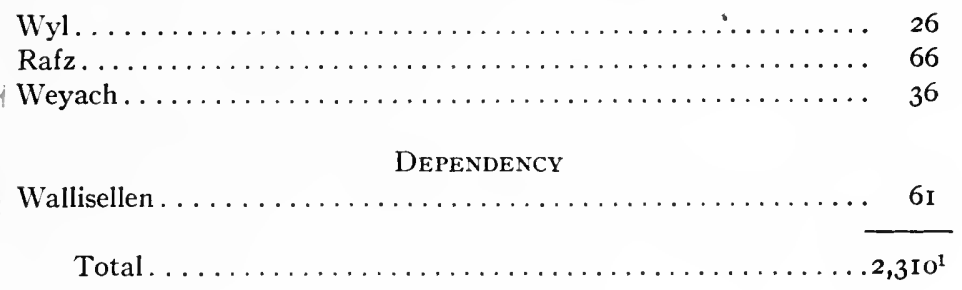

No. 2. List of those Families and Persons who, from 17341744, Left the Parish Affholteren at Mt. Albis for (A) Carolina, (B) Pennsylvania

\section{(A) LefT For Carolina}

I734 (a) Family. Hans Grob with his wife Cathrj Ruestin, a son and two daughters.

I739 (b) Elsbeth Muller, grown-up daughter of Jacob Müller, deceased.

\section{(B) Left for Pennsylvania}

I736 Two grown-up help-mates. Hans Jacob Dups, Heiri's (man), and Rudolff Haug, Uli's (man). N.B. Their first trip.

I 743 (a) Families.

I. Caspar Schnebelj Ottlis with his wife Verena Dups and four little children.

2. Conrad Wyss, cooper, with his wife Barbara Dups and four young children.

3. Felix Wyss, carpenter, with his wife Anna Huber and five little children.

4. Johannes Epprecht with his wife Verena Walder and one little child.

5. Conrad Näff with his three sons.

6. Hans Heinrich Hurter with his wife Verena Huber and one young child.

(b) Grown-up Help-mates.

I. Hans Jacob Dups, Heiri's.

2. Rudolff Haug, Uli's. N.B. Their second trip.

3. Hans Dups, the above Hans Jacob's brother.

4. Leonhard Schnebelj, Heiri Schnebelj's, the inn-keeper's (man).

5. Heirj Epprecht, Joose's (man).

6. Hans Heinrich Epprecht, Jacob's (man).

7. Heinrich Suter, the deceased Hans' (man).

8. His brother Hans Suter.

9. Hans Jacob Suter, the deceased Rudi's (man).

ı. Hans Schnebelj, Rüetschj Heiri's (man).

II. Heinrich Rudolff, the deceased Jacob's (man).

12. Hans Jacob Schärer, Krämer's (man).

(c) Boys under age.

I. Leonhard Haug, Färber's.

2. Conrad Epprecht, Joose's.

3. Rudolff Kleiner.

${ }^{1}$ The total of the figures given is 2,262 , not 2,310 . The discrepancy may be accounted for by the omission or loss of the names of one or more parishes in the tabulation. 
(d) Grown-up daughters.

I. Barbara Haug, Uli's.

2. Ana Schnebelj, Rüetschj Heiri's.

Total $5^{2}$ souls.

Affholteren at Mt. Albis, April 22, 1744 .

Attested by

HaNs UlRich Wyss, p.l.

(i.e., pastor loci, i.e., pastor in the parish.)

No. 3. The following Persons from the Parish Affholteren

AT HöNGG HAVE, AS FAR AS IS KNOWN, WithdRAWN Within A Few Years, and Gone to Pennsylvania or Carolina

I. Jacob Matthysen's (in Unter-Affholteren) daughter, aged 28, withdrew six years ago.

2. Caspar Merkj (in Ober-Affholteren), smith and drummer, aged 29, with

3. His wife: Anna Dietschj, of the same age, left on account of debts. I7+3.

4. Johannes Clingler, aged 29, left the same place, without the knowledge even of his parents, leaving behind wife and child, in the aforesaid year I 743 .

No. 4. From the Parish Altikon there journeyed to Carolina, Between I $734^{-1} 744$

\section{From Altikon}

1734. I

$\left.\begin{array}{l}\text { Rudolff Meyer, aged } 30 \text { years and } \\ \text { Anna Hasenfraz, “ } 28 \text { " }\end{array}\right\}$ Married couple.

Anna Hasenfraz,
Children:

Magdalena, aged 4 years.

Maria, "I year.

I 735. 2

Rudolph Baumer, Felix Baumer's son, aged 26 years.

3

Jacob Ammann, Jacob Ammann's son, aged 24 years.

$\left.\begin{array}{l}\text { Christoph Müller, aged } 30 \text { years and } \\ \text { Barbel Baumer, " } 28 \text { " }\end{array}\right\}$ Married couple.

I 743. 5

Jacob Kreysz, aged 46 years and

Anna Bachmann, " 42 " Children:

Hans Ulrich, aged i 8 years.

Hans Jacob, " I6 "

Hans Felix, " 8 " “

Anna, " 6 "

- Total from Altikon: I4 Persons.

From Dorlikon

I738. I

$\left.\begin{array}{l}\text { Hansz Nüssli, Oeler, aged } 42 \text { years and } \\ \text { Angelica Meyer, " } 37 \text { " }\end{array}\right\}$ Married couple.

Children:

Elisabeth, aged I 4 years. 
Barbara, aged 12 yeaes.

Angelica, " Io "

Verena, " 7 "

Anna, " 5 "

Heinrich, “ 3 “

$\left.\begin{array}{l}\text { Conrad Basler, aged } 33 \text { years and } \\ \text { Anna Baumer, " } 35 \text { " }\end{array}\right\}$ Married couple.

Child :

Conrad, aged 7 years.

$\left.\begin{array}{ll}\text { Christoph Weydmann, aged } 37 \text { years and } \\ \text { Elsbeth Schmid, }\end{array}\right\}$ Married couple.

Children:

Heinrich, aged I y years.

Ulrich, "6 "6

Hans Caspar, " $1 / 2$ year.

I743. 4

$\left.\begin{array}{l}\text { Hans Ulrich Müller, aged } 4 \text { I years and } \\ \text { Verena Bolsterlj, " } \\ 42\end{array}\right\}$ Married couple.

Children:

Dorothea, aged I I years.

Anna, " " 4

Hans Ulrich, “ I year.

$\left.\begin{array}{l}\text { Rudolph Epprecht, aged } 44 \text { years and } \\ \text { Anna Grügis, }\end{array}\right\}_{46}^{5}$ Married couple.

Anna Grügis,
Children:

Jacob, aged 2I years.

Rudolph, " I8 "

Anna, " It "

Margreth, " I2 "

Elisabeth, " 8 "

Verena, " 5 "

Total from Dorlikon: 29 Persons.

Altikon, April I5, I 744 .

Caspar Ulrich, Minister.

No. 5. From Alltstätten there went away on the 23. July, i743, with the Purpose of Going to Pennsylvania

Margrethe Hindermann's two sisters, of the same name, the one 39, the other 36 years old.

Otherwise no one.

Which report herewith, because of no better opportunity known, is sent to accompany the Circular,-while commending himself most respectfully to His Grace, the Dean, by

Joh. Caspar Hess, p.l.

From Wollishoffen none, God be praised, have gone away. God grant, that also in the future no one's mouth will water for this country.

From Kilchberg no one has gone away, "principiis obstandum fuisset."

From Rüschlikon also no one has left. As far as I know, the thought never entered anyone's mind to go away from here. 


\section{No. 6. With the Intention of Going to Carolina there went AWAY FROM THE PARISH ANDELFINGEN}

I 734, the I. November. Anna Bretscher, from Atlikon, unmarried, aged 26. But the report came later that this disorderly person got to Piedmont and died there.

1738, the beginning of September. Adam Angst, tailor, from Niderwyl, aged 36 . His wife Barbara Räss, aged 35. Child: Elisabetha, aged $21 / 2$.

“ Hans Jacob Schaub, from Niderwyl, unmarried, aged 26.

His sister Anna, unmarried, aged 21.

“ Anna Moser, from Öhrlingen, unmarried, aged 261/2.

“ Jacob Bucher, from Alten, who left his wife, aged 58.

His son with him, Hans Conrad, aged 26.

“ Hans Jacob Ullman, from Altlicken, aged 32.

His betrothed Anna Landolt from Kl. Andelfingen, aged 29.

These, however, did not get farther than Basel, and from there to the district of Durlach, where they were married. He is said to be in service there still, but the woman returned to her parents pregnant, in December I74I, where she gave birth to a child that died, subsequently she went into service again.

I 743 Went away Tuesday after Witsuntide.

Heinrich Schaub from Niderwyl, aged $5 \mathrm{r}$.

His wife Anna Barbara Bertschinger, aged 331/2.

Children by the first marriage: Anna, aged 22

$\begin{array}{lll}\text { Hans Ulrich, } & \text { " } & 20 \\ \text { Adam, } & \text { “ } & 181 / 2 \\ \text { Jacob, } & \text { “ } & 16 \\ \text { Johannes, } & \text { “ } & \text { Io } \\ \text { Hans Conrad, } & \text { “ } & 8 \\ \text { Susanna, } & \text { " } & 21 / 4\end{array}$

Child by the second marriage: Susanna, " $21 / 4$

There also left at that time:

Heinrich Angst from Niderwyl, unmarried, joth without a pass aged $271 / 2$.

His sister Elsbeth, unmarried, aged 26.

1743 Anna Hagenbuch, from the same place, unmarried, aged 27 .

Her brother, Hans Jacob, aged i 8 , who has not yet received the communion. and certificate from pastor.

Both of these left without pass or certificate.

“ the 13. June. Hans Ullmann, from Atlikon, aged $4 \mathrm{I} 1 / 2$.

His wife Magdalena Hirt, aged $301 / 2$.

His child by first marriage Johannes, aged $31 / 2$.

He died in London, and according to a report received a week ago, which sounds lamentable, she is still there with the step-child in a despicable condition of poverty. The letter has come through Rieslimann of Winterthur.

“ the 6. July. Hans Conrad Schaub of Niderwyl, aged 291/2.

His wife Anna Frey, aged $321 / 2$.

Children: Hans Conrad, aged $31 / 2$, Hans Jacob, aged $21 / 2$.

Also with him his sister Ursula, aged 23, and brother Heinrich, aged 2I (unmarried).

“ the I. April. Jacob Meisterhans, mason, from Andelfingen, aged 5I.

His wife Verena Bernhardt, aged $4 \mathrm{I}$.

Children: Hans Conrad, aged $121 / 2$.

Anna Elsabetha, " $91 / 2$.

Hans Jacob, “ $4 \frac{1}{2}$. 
I743 With him there left also, without desiring from me a certificate:

Hans Jacob Islicker, from Klein-Andelfingen, aged 50.

His wife Anna Himmel, aged 58.

Their illegitimate daughter Anna Hegin from Cappel, unmarried, aged 251/2.

“ Jacob Sigg, also from K1. Andelf., aged 46.

His wife Regula Eigenheer, aged 34.

Children: Margaretha, aged 81/2; Hans Jacob, aged 6.

“ Heinrich Süsstrunk, shoemaker from Humlicken, aged 291/2.

His wife Ursula Üly, aged 25.

Child: Hans Ulrich, 8 months.

He also took with him his sister Barbara, aged $171 / 2$, who has not yet received the communion.

Testified from Andelfingen, April Iо, I744. JoH. Sсноор, Minister.

\section{No. 7. List of those Persons who since the Year i734 Jour- Neyed from the Parish Bachs to the New World}

Junghans Maag, born July I 5, 1703, secretly left his wife and child.

Junghans Meyer, son of Jacob Meyer, deceased, unmarried, born March 28, I 706.

CHeinrich Keller, born January 2, 1684.

$\{$ Margeth Scheur Mejer, his wife, born February 6, 1687.

Margeth, his child, born June I2, I729.

Hans Jacob Schüz, the deceased Hans Jacob Schüz's son, unmarried, born April I 7, I 718 .

Rudolff Schüz, Rudolff Schüz's legitimate son, unmarried, born July I7, I7I5.

$\{$ Felix Kunz, born October 13, 1695.

Anna Dutweiler, his wife, born November 6, I68I.

$\int$ Vrena Pfister, wife of the deceased Schüz, born September 24, I682.

$\{$ Felix, son, born May 21, I7 16 , unmarried.

Rudolf, son, born April 23, I7I9, unmarried.

$\{$ Hans, a brother, born October 22, 1713.

$\{$ Vrena Bleüler, his wife, born September 3, 1713.

Hans Caspar, her son, born February 8, I739.

Klihans Kunz, Heinrich Kunz's (the rope-maker's) legitimate son, unmarried, born August 26, 1716.

Jacob Pfister, Klihansen's legitimate son, unmarried, born September 27, I716.

Klihans Vrener, born May 21, I7I 4.

$\{$ Regula Bräm, his wife, born December I9, I699.

Caspar Vrener, his brother, unmarried, born October 6, I720.

Barbara Kunz, Hans Kunz's legitimate daughter, born March 9, I721, unmarried.

Hans Kunz, her brother, unmarried, born September I4, I 730 .

Jacob Bucher, born April 10, 1696.

Barbara Albrecht, his wife, born October 12, 1695.

Children:

Jacob, born September I, 1725 .

Heinrich, born May I 7, I 728 .

(Jacob Schüz, born April I, I697.

Margeth Huber, his wife, born August I0, I 706.

Children:

Anna, born May 28, I730.

Elsbeth, born August 31, 1732 .

Heinrich, born February 13, 1725 .

Hans Heinrich, born May 26, I 735 .

Barbara, born October 9, 1740. 
Magdalena, Felix Majer's legitimate daughter, unmarried, born July 8, I7I4. $\int$ Jacob Mejer, born August I 2, I703.

$\{$ Susanna Hug, his wife, born March 7, I697.

Her child:

Vrena, born March 22, 1728 .

Hans Jacob Weidmann, Felix's legitimate son, unmarried, born October 22, 1720 .

CHans Weidmann, born October 8, I 702 .

Anna Surber, his wife, born December I 5, I 700.

Children:

Anna, born May 21, I732.

Anna, born August 29, 1734 .

Rudolff, born September 12, 1737 .

Hans Bernhardt, born May I4, I699.

Vrena Schüz, his wife, born October 26, I 704 .

Children:

Cleophea, born December I4, 1728.

Heinrich, born September I4, I 730 .

Hans Heinrich, born February 20, I 735.

Hans, born January I, I 738 .

Anna, born August 16, 1740 .

$\left\{\begin{array}{l}\text { Anna, born July 3, I707. } \\ \text { Heinrich, born February 2, I718. } \\ \text { Johannes, born May 4, I 724. }\end{array}\left\{\begin{array}{l}\text { all unmarried, the deceased Hans IVeid- } \\ \text { mann's children. }\end{array}\right.\right.$

Johannes, born May 4, I 724.
Felix Mejer, born January I, I 705 .

Barbara Hollenweiger, his wife, born September 25, I698.

Child:

Regula, born May 19, 1737.

Total: 56 Persons.

Attested from the record-book of baptisms, March 25, 1744 .

By Johann Caspar Schweyzer, Minister at Bachs.

\section{No. 8. Froli the Parish Bäretschweil in I 742}

Hans Heinrich Meyer from the Hinderberg went to Carolina, leaving his wife behind somewhere about Lake Zürich, got possession of about 50 florins and absconded. He was baptized in February 1697.

Bäretschweil, April I8, 1744 .

Attested,

PASTOR SCHMid.

No. 9. List of those Pitiable Persons, who Contrary to Faithful Warnings and Admonitions Obstinately went AWAY From the PARISh BAsserstorfF, with the intention of seeking their fortunes in Carolina or Pennsylvania.

I 734

I. Heinrich Brunner, son of Jacob, deceased, called the trumpeter of Basserstorff, born May 3, I7 6 .

2. Susanna Keller, illegitimate daughter of Caspar Keller, deceased, born May 25, I 7 I 5 .

3. Heinrich Dübendorffer, called Christen Hugen, born October 3, I695.

Barbara Meyer, his wife, born in Wallisellen.

Children: 
Rudolff, born April 22, I 726.

Anna, born February I8, I 731 .

Barbara, born April 25, I 734.

4. Hans Jacob Dübendorffer, called Krebser, born April I2, I696.

His wife Magdalena Krebser from Wallisellen.

5. Hans Heinrich Enderli, called Schörulis, born July 28, I7oo.

His wife: Anna Keller from Oberembrach.

Children:

Heinrich, born August 12, 1725 .

Regula, born July I 8 , I 728 .

6. Heinrich Dübendorffer, the mason's son, born May 8, I 698.

His wife: Verena Widmer from Ottikon.

Child:

Felix, born November 17, I733.

7. Hans Dübendorffer, called Küeffer, the tailor's son, born February 2, I70I.

His wife, Lisabeth Keller from the parish Embrach.

Children:

Rudolff, born January 19, 1727 .

Hans Geörg, born January 23, 1729.

Elsbeth, born December 25, I73I.

Katharina, born June 27, 1733 .

8. Kilian Dübendorffer, called Krebser, born February I9, I704.

His wife, Verena Krebser from Wallisellen. Children:

Abraham, born December 5, I 728 .

Anna, born March 22, 1733 .

9. Heinrich Hug, wainwright, a widower, born September 27, I668. Died on the ship to Pennsylvania.

Io. Christophel Leimbacher from Oberwil, Heinrich's son, born June 25, I7 3 .

I I. Felix Leimbacher from Oberwil, born September I 4 I684.

His wife: Anna Meyer, born October I2, 1689.

Children:

Felix, born March 15,1711 , is in the Dutch Service.

Hans Heinrich, born July 6, I7 17 , with his parents.

Anna, born October 30, 1725 .

Lisabeth, born April I I, I 728.

Barbel, born February i 8, I 73 I.

12. Hans Heinrich² Brunner, son of the deceased Heinrich, tailor, unmarried, born December I9, I 728.

${ }^{2}$ Heinrich is written above the name Ulrich, crossed out.

I743. Left Sunday, May 5

I. Heinrich Dübendorffer, called Krebser, born March 5, I 702.

His wife: Anna Wegmann from Tagelschwang, born 1703 .

Married December 19, I728.

2. Hans Jacob Reutlinger, Kaspar's son, unmarried, born July 30, I 719.

3. Salome Brunner, Hans Brunner's deceased wife (née Hursel), called Link's daughter, born June II, I 724 .

4. Heinrich Leimbacher, deceased Jacob's son from Oberwil, unmarried, born November 26, I 7 I9.

5. Elsbeth Vetter, daughter of Jacob, left with Hans Jacob Brunner from . Kloten, since the parish Kloten objected to their marriage. Born August 8, I 7 I 7 .

6. Jacob Altorffer, deceased Kaspar's son, from Birchwil, unmarried, born October 5,1727 . 
7. Leonard Altorffer, smith from Basserstorf, born August Io, I 700.

His wife, Anna Frener from Wangen, born May I 7, I 706, married February 5, I73I.

Children:

Kaspar, baptized, January I 8, I 739 .

Hans Jacob, July I 5 , I 742 .

8. Susanna Bachmann, the deceased Jacob Ringger's widow, from Nürrenstorff.

Born August 20, 1707, left with her own son, Heinrich,

Baptized March I3, I 735, and three sons by her first marriage.

Born by Barbara Morff from Effretikon.

Hans Jacob, baptized September 24, I724.

Hans Caspar, baptized December 25, 1727 .

Jacob, December 4, I729.

9. Left the IIth of May.

Hans Jacob Leimbacher, Hans Heinrich's son, from Oberwil, unmarried, born April 30, 1724.

Io. Hans Jacob Brunner, called Trumpeter of Basserstorff, born September 22, 1709.

Anna Meyer, from Embrach, his wife, born June 12, 1707.

Left the I5th of May.

II. Heinrich Brunner, son of Rudolff, deceased, from the Hub, unmarried, born January 9, I 7 I 8 .

I2. Jacob Hess, Caspar Hess' (from Ettenhausen) illegitimate son, lived at Basserstorff with his mother Anna Hugg, baptized here January 26, I7 19.

13. Ulrich Brunner, tailor, surviving son of Kilian Brunner and Verena Altorffer, from Basserstorff, unmarried, born February 22, I 722.

14. Hans Brunner, cooper from Basserstorff, born May I8, 1690.

His wife: Barbara Redinger from Höngg. Married August.26, I 727.

Children:

Hans Jacob, baptized, December 27, 1727.

Hans Ulrich, " June I4, I730.

David, “ August 17, I732.

Abraham, “ " October 24, I734.

Felix; “ December I3, I739.

Anna Margreth, " October 22, $174^{-}$.

15. Left July 4 th.

Felix Bachmann from Oberwil, born December I8, I70r.

His wife: Regula Morff from Hakab, born May Io, I 7 II.

Children by the first marriage are:

Anna Hinen from Dietlikon.

Rudolff, born December 2I, I732.

Anna, born April 7, I 735 .

Attested,

Hans Ulrich Geszner, Pastor at Basserstorff.

No. Io. In AcCordance with the Magisterial ORder ReCEIved, THE Minister of BänkeN INForms His Honor, Dean BRUnNer, that No ONE has Left the Parish of BänkeN FROM I 734 UNTIL NOW: that at present, however, three families have the wish to leave, to wit:

I. Johannes Studer with three children and his wife.

2. Jacob Meister, locksmith, with his wife.

3. Johannes Meister, the glazier, with his wife and three children. 
These, however, have been held up by His Honor, the Chief Magistrate (Kreis-Obervogt) in Lauffen, until after Easter, and as a result will probably have to remain.

April 3, I 744. Pastor WunderliJ at Bänken.

\section{No. i i. From the Parish Birmenstorff the following have gone to Carolina and Pennsylvania}

Lisabeth Haffner, the deceased Hans Haffner's daughter, born April I, I 706, left two years ago.

Eva Hedinger, the deceased Hans Hedinger's daughter, born August 30, 1705, left in 1738 .

Felix Wintsch from Landicon, born October 7, I724, left in 1743 .

Katharina Wintsch, his sister, born April I4, I 726.

Hans Stierlin from Aesch and his wife Anna Rasi, together with the 4 children:

Jacob Stierlin, born October 2I, I7 I5; Hans Stierlin, born January 26, I 7 I 8.

Gregorious Stierlin, born November 22, I 722 ; and Ursula Stierlin, born February 25, I 725 .

Hans Gut from Aesch and his wife Elsbeth Beerlj, with their daughter Margaretha Gut, born December 24, I 7 I 4 .

Caspar Hoffstätter, born October I, I 7 I3.

Hans Jacob Meyer, also from Aesch, born September 19, 1707.

Total is Persons.

No. 12. List of Persons who left the Parish Bonnsteten to go to Carolina and Penssyluania

Withdrew in September $173^{8}$.

Born:

October 28, 1701. Caspar Toggweiler, called Schwab.

December Io, I 709. Anna Huber, his wife.

Their children:

February I2, I730. Barbara.

June 24, I73i. Margreth.

July 2I, I737. Hans Heinrich.

June 24, I703. Felix Glätlj, Chlyrüdis.

October 4, I69I. Catharj Huber, his wife.

January 9, 1689. Felix Frey.

September 23, I688. Barbara Blikenstorffer, his wife.

Their children:

September 13,1718 . Jacob.

March 6, i725. Hans Heinrich.

Also the following unmarried people.

April I7, 1717. Heinrich Aeberlj, son of Hans.

July 26, I696. Heinrich Glätlj, son of the purser, deceased.

April 22, I714. Hans Jacob Huber, son of the bailiff.

August I6, I7II. Heinrich Glätlj, son of Caspar deceased.

February I4, I 723. Anna Huber, daughter of Marti deceased.

Withdrew in May 1743 . $\left.\begin{array}{ll}\text { August 19, 1716. } & \text { Cilian Gilg. } \\ \text { December } 17,1720 . & \begin{array}{c}\text { Hans Aeberlj, son of Hans } \\ \text { deceased. }\end{array}\end{array}\right\} \begin{gathered}\text { They were in service in the } \\ \text { district of Knonau. }\end{gathered}$

Withdrew April I, I744.

December I8, I7I4. Regul Gilg, daughter of Chlyjoggen deceased, left Knonau where she served. 


\section{No. I3. There have gone to Carolina from the Parish \\ BRÜTTEN}

I. 1740. Heinrich Käller, born I718, April 20, unmarried.

2. 1743. Felix Gross, born March 24, I715, unmarried.

Verena Stäffen, born April 4, I 718, unmarried.

Hans Conrad Gross, born April 6, I721, unmarried.

Barbara Stäffen, born April 9, I 7 1 7, unmarried.

Lisabeth Baltensberger, born August 20, I720, unmarried.

Hans Heinrich Baltensberger, born August I 8, I7 15 .

His wife, Barbara Sommer from Rümikon, born in the parish of Elsauw

February I7, I7II. She was in an advanced state of pregnancy at her departure.

Finally there left Rudolf Gross, born September 26, 1716.

His wife was Barbara Städeli from Basserstorff, born August 9, I 703 .

The children are:

Heinrich, born 1732 .

Rudolf, born April 6, I 734 .

Lisabeth, born 1738 .

Hans Ulrich, born April 9, I $74^{\circ}$.

\section{No. I4. From the PARISh Bubikon there Withdrew FOR Carolina}

1738. Conrad Zollinger and Lisabeth Zollinger with eight children, got as far as the Markgrafenland (S.W. section of the Black Forest, in Baden), where they remained for two years on fief-land. The father died and the mother returned with eight children.

Regula is married in the city of Basel.

Hans Rudolf is in service in Basel.

Hans Heinrich is also serving in Basel.

Hans Rudolf is working also in the Basel-district.

Hans Caspar died.

Hans Ereth

A. Barbara These three are being brought up in our parish.

Hans Jacob

1743. Hans Hürliman and Maria Keller with three young children got to Basel and after he had spent all his money, returned. He wishes to burden the church with the bringing up of his three children:

Maria, born September 30, 1736 .

Heinrich, " April 3, I738.

Elsbeth, “ March 17, I740.

No. I 5. List of Persons who from the Parish Bülach between I 734 ANd 7744 Journeyed to Carolina And Pennsylvania

\section{FROM BÜLACH}

1734. Hansz Jacob Kern, the deceased sexton's son, unmarried.

\section{From BaChenbüLACH}

1734. Abraham Bäninger, carpenter.

His wife, two sons.

I738. Hansz Maag.

His wife, three children. 
1738. Salomon Mejer.

His wife.

Hansz Jacob Maag, Alexander's son.

His wife, three children.

Salomon Mejer, tailor.

His wife, four children.

Heinrich Zander.

His wife, three children.

I 743. Jacob Maag.

His wife, two children.

Andreas Maag.

His wife, two children.

Total from Bachenbülach 35 souls.

\section{There Went from Eschenmosen}

I738. Johanes Steiner, Caspar Steiner, both unmarried.

1743. Johannes Hildbrand, the deceased Jacob's son, together with his wife. Johannes Hildbrand, the deceased Hans Jacob's son, unmarried.

Jacob Maag, resin-scraper.

His wife, three sons, two daughters.

Total: 12 persons.

\section{THERE WENT FROM WINKEL}

1738. Hans Dutweiler.

His wife, two children.

Jacob Mejer, the deceased Conrad's son.

His wife, three children.

Hans Conrad Mejer, wainwright.

His wife, one child.

Barbara Dutweiler, unmarried.

Anna Mejer, also unmarried.

Total from Winkel: I4 persons.

\section{THERE WENT FROM HOCHFELDEN}

I738. Joseph Volkert.

His wife Frena Friesz, two sons, one daughter.

Junghans Maag.

His wife Anna Herzog, one daughter.

Catharina Mejerhofer, Hans Heinrich Mejer's widow.

One son, one daughter.

Junghans Frälj.

His wife Barbara Engel, one son, one daughter.

I743. Junghans Mejer.

His wife Verena Huber, two daughters.

Hans Jacob Mejer, the above-named's broth r, unmarried.

Daniel Horner.

His wife Anna Kern.

Total from Hochfelden: 22 persons.

1734 .

\section{THERE WENT FROM HÖRENEN}

ENDHÖRJ

Hans Heinrich Gaszmann, died on the way.

His wife Magdalena Frölj.

One child, Barbara Gaszmann. 
1734. Heinrich Gaszmann, died on the way.

His wife Verena Engel.

Two sons, Hans Jacob and Heinrich.

I739. Hans Gaszmann.

His wife Anna Bertschj.

One son, Hans Martin, one daughter Anna Catharina.

Junghans Pfister, tailor.

His wife Babelj Gaszmann.

One son, Heinrich, two daughters Dorothe and Barbara.

Junghans Pfister, the deceased Jacob's son, unmarried.

Hans Heinrich Oertlj.

His wife Regula Oertlj.

Two sons, Felix and Heinrich, two daughters, Kljverena and Anna.

Hans Jacob Frölj.

\section{NIDERHÖRJ}

His wife Elsbeth Brunner.

Two children $\left\{\begin{array}{l}\text { Elsbeth died in Rotterdamm. } \\ \text { Barbara died on the sea. }\end{array}\right.$

Total from Hörj: 27 persons.

The grand total of all souls, that emigrated from the parish Bülach is III souls. Attested by Pastor Simler. Bülach, April I I, I 744 .

\section{No. i6. List of the Persons who went from the Parish Buchsz to Penssylvania}

I734. September 27.

I. Hans Conrad Meyer, born 1682.

2. Magdalena Weidman, born 1682 .

Son.

3. Melchior Meyer, born 1720.

4. Jacob Murer, born 1687 .

5. Elsbeth Murer, born 1690.

Children:

6. Margeth, born 1720 .

7. Anna Margeth, born 1727.

8. Hans Heinrich Murer (cousin of the above). Deceased Jacob Murer's son, born I 720 .

9. Heinrich Huber, born 1698.

I0. Ursula Grendelmejer, born 1707 . Boys:

II. Hans Rudolff, born 1732 .

12. Hans Jacob, born I733. Died in Rotterdamm.

13. Jacob Schmid, born 1692.

14. Cathrina Koch, born I697. Died in Rotterdamm. Children:

15. Anna, born I7ig.

16. Jacob, born 1720 .

17. Felix, born 1722 .

18. Kly Anna, born 1729.

19. Johannes, born I73I. Died in Rotterdamm.

20. Felix, born 1733 . Died in Rotterdamm.

I738. August 22.

21. Heinrich Grendelmeier, born I70r.

22. Margeth Grendelmeier, born 1705 . 
Children:

23. Heintich, born 1727 .

24. Margeth, born 1728 .

25. Elsbeth, born 1730 .

26. Felix, born 1733 .

27. Barbara, born 1735 .

28. Anna, born 1737 .

29. Heinrich Meyer, born i 701 .

30. Anna Vogler, born 1707 .

Children:

31. Vrena, born 1726.

32. Cathrina, born 1730 .

33. Barbara, born 1732 .

34. Felix, born 1734 .

35. Anna Barbara, born $173^{8}$.

36. Hans Heinrich Meyer, born 1698.

37. Vrena Grendelmeyer, born I 706.

Children:

38. Conrad, born 1729.

39. Elsbeth, born 1735 .

40. Regula, born 1737 .

41. Felix Meyer, born I 704.

42. Vrena Meyer, born I 705 . Boys:

43. Jacob, born 1734 .

44. Felix, born 1737 .

Buchs, March 31, I744.

Attested, Heinrich Ull.rich, Pastor.

No. I7. Cappel. From this Parish there Journeyed to Carolina in August I734

$\left.\begin{array}{l}\text { Jacob Müller, baptized March I9, I 7 I3. } \\ \text { Vrena Müller, baptized January I3, I7 } 15 .\end{array}\right\}$ Brother and sister.

Rudolf Lier, baptized May I8, I718, was unmarried.

In May I 739 another group left for Carolina:

Rägul Hägj, baptized December 22, 1715.

Barbel Hägj, baptized March 30, 1718 . Unmarried brothers

Hans Jacob Hägj, baptized May I2, 1720. $\}$ and sisters.

Jacob Hägj, baptized September 24, 1721.

Johannes Hägj, baptized April 30, I7 I9, unmarried. $\}$ Brother and sister.

Vrenelj Hägj, baptized December 7, I 721 , unmarried.

$\left.\begin{array}{l}\text { Jacob Grob, baptized November 9, 1708. } \\ \text { Susann Furrer, baptized August 19, I } 708 \text {. }\end{array}\right\}$ Married couple.

In April 1743 there went to Pennsylvania:

Heinrich Müller, baptized February 14, I 720, unmarried.

Thommen Lier, baptized September 26, I725, unmarried.

Jacob Bär, baptized April 28, I720, unmarried.

Ulrich Vollenweider, baptized December 5, I723, unmarried.
April 25, I744.
Attested, Matthew Eszlinger, Local Pastor. 


\section{No. i 8. List of those Persons who left for Carolina from THE PARISH DÄGERLEN}

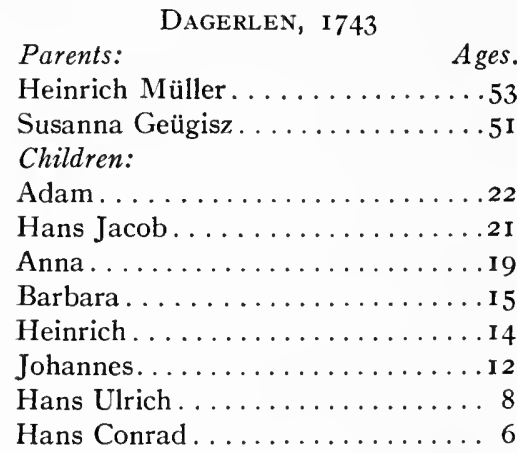

Parents:

RUTSCHWILL, I 743

Johannes Hagenbuch . . . . . . . . 4 43

Margretha Schmid...........47

Children:

Jacob.................... I

Johannes.................. 6

Hans Heinrich . . . . . . . . . . I5

Junghansz................ Io

Margretha................ 8

Ulrich................. 6

\section{Parents:}

Verena Schnider, Ulrich Müller's widow . . . . . . . . . . . . . . 36

\section{Children:}

Hans Heinrich . ............... I4

Ulrich................. I 2

Jacob.................... I I

Barbara.................. 9

Ursula .................... 6

Ulrich Waser, unmarried son of Joseph Waser............... 30

\section{Parents:}

Ursula Gischberger, whose husband had run away. .........29 Children:

Ulrich Müller, stepson.........2o

Rudolph................... 2

Anna .................. weeks

\section{BERG, I734}

Jacob Hagenbuch . . . . . . . . . . 36

Barbara Bachmann...........37

BERG, 1738

Verena Ages
Parents:

Anna Dändliker, Jacob Wolffens-

berger's widow .......... . I Children:

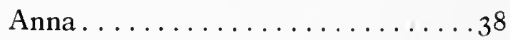

Hansz . . . . . . . . . . . . . It

Jacob................. I2

Regula................... Iо

B ̈̈NK, I 743

Hans Ulrich Schwarz, Jacob

Schwarz's son . . . . . . . . . I 8

OBERWILL, I738

\section{Parents:}

Jacob Stuki . . . . . . . . . . . 46

Barbara Hugenbergerin . . . . . . . . 47

Children:

Daniel...................20

Jacob................ I 8

Johannes. . . . . . . . . . . . . I6

Peter.................... I3

Ulrich. . . . . . . . . . . . 7

$\{$ Laurenz Blatter, unmarried;

$\left\{\begin{array}{l}\text { Andreas Blatter's son ....... I I } \\ \text { A }\end{array}\right.$

OBERWILL, 1743

Parents:

Andreas Blatter............. . 56

Maria Dietrich.............54

Children:

Johannes. . . . . . . . . . . . I 7

Verena.................. I5

\section{Parents:}

Bernhardin Erzinger. . . . . . . . . 39

Barbara Blatter............ . .47

Children:

Barbara................ I7

Kathrina............... 3

Parents:

Adam Blatter...............45

Margretha Wuhrmann.........44

Children:

Verena.................. I2

Johannes................ 9

Barbara................ 5

Magdalena............... 3

1743

Barbara Weber, Daniel Morff's wife................. 54

Total: 6I persons. 


\section{No. 19. Dellickon. List of those Persons, who Left for the Country Carolina}

September 27, 1734, Regula Weisz left for that place, legitimate daughter of Rudj Weisz and Barbara Schwällj, both of Dellickon. She was baptized September I 8, I 7 12. (Documentary proof.)

After this daughter had given promise of marriage to the carpenter's mate, Johannes Matthysz of Watt, these two persons were united in marriage on my recommendation in the city of Basel, by Mr. M. Andreas Merian, candidate for the ministry.

August 27, I 738, there journeyed to the aforesaid land the following persons: I. Heinrich Spillmann, wainwright, from Dellickon. Baptized December 25, I692. (Documentary proof.)

2. Elsbeth Rümeli, from Seebach, wife of the preceding. Baptized July 24, I687.

(Documentary proof.) Children:

3. Heinrich, baptized October 20, 1722.

4. Verena, baptized February 18, 1725.

5. Caspar Spillmann, brother to the above, baptized August 7, I7or. (Documentary proof.)

6. Anna Müller, from Schlieren, baptized December 8, I 7oo. (Documentary proof.)

7. Hanseli Spillmann, the son of the last-named brother, baptized July 9, I730.

From the above-mentioned Heinrich Spillmann, wagon-maker, a letter has come, dated May 19, I743, from Carolina, concerning the truthfulness of which there is doubt, owing to various causes.
Dellickon, April 2, I 744 .
Hans Jacob OerJ, Pastor.

\section{No. 20. Dättlikon, March 27, i744. (SeE Plate I)}

About nine years ago, there journeyed from here to Pennsylvania, and established himself near Philadelphia, as a report to me from there shows:

Jacob Weydmann, a mason, aged 40 , with his wife and four small children. In spring, a year ago, there followed after him, contrary to my admonition, preached from the pulpit in a sermon specially devoted thereto, and in spite of remonstrances in private:

I. Heinrich Bretscher from Blumetshalden, aged 27, and his wife Anna Wetzstein, aged I9, with her brother Jacob Wetzstein, aged 2I. They carried a good sum of money along with them, how much I do not know.

2. Heinrich Müller, aged 42, and his wife Margaretha Herzog, aged 39, with four small children, and the sister of Müller, Ursula, aged 46. He also took along a good amount of money, the sum is not known to me.

3. Felix Ernst, aged 37, and his wife Elsbetha Weydmann, aged $4 \mathrm{I}$,

4. The above Jacob IVeydmann's sister, also with four small children; she had little money.

Then Heinrich Weydmann, unmarried, aged 23, was also provided with a sum of money.

I do not know of anyone who has a desire to follow the above, but one or another may be concealing his wish, cherished within, and be waiting only for a report as to how those fared who left.

The paternal care of our gracious rulers is Christian, good, necessary, praiseworthy. But along with this, it is no less good and necessary, if one gives to the poor industrious but unemployed people enough work for their necessary sustenance, or otherwise gives them some needy assistance, then they would be glad to remain in their native land.

This is written with my feeble hand. (Haec manu infirma.) 
No. 21. From the Parish Dielstorff the Following Family HAS GONE AWAY TO CAROLINA

$\left.\begin{array}{l}\text { Heinrich Kuhn } \\ \text { Regula Zöbelj }\end{array}\right\}$ Parents.

Felix Kuhn

Heinrich Kuhn $\}$ Children.

Peter Kuhn

Total five persons.

Dielstorf, March 31, I744.

Attested,

Hans Heinrich Wirtz, Pastor.

No. 22. From the Parishes Dietlikon and Rieden the Following Families and Persons have left for

Carolina and Pennsyluania

1734. I. Jacob Hunen, called Bieler's, born I 700 .

2. His wife Elsbeth Mejer, born January I0, I699.

3. Regula, their daughter, born November 2, I 727 .

4. Ulrich Schwarzenbach, from Rieden, born September I, I 705 .

5. His wife Barbel Hänslj, from Brütten, born May 29, 1798 .

6. Felix, their son, born April I2, 1733.

7. Heinrich, their son, born September 19, 1734 .

1739. 8. Caspar Kuhn, from Rieden, born October Io, I7I3.

9. His wife, Anna Magdalen Mejer, from Rümlang, born January 2I, I7I 4.

10. Anna, their daughter, born April 29, I739.

1743. I1. Kilion Hinnen, mason, a widower, born December 16, 1694.

12. Jacob Rathgeb Schneider, from Dietlikon, born April I5, I703.

13. His wife, Anna Wintsch, born January I9, I7I2.

14. Hans Rudolff, their son, born September 9, 1734 .

15. Regula, their daughter, born March 23, I 737 .

16. Heinrich, their son, born July 6,1738 .

17. Hans Conrad, their son, born October 2, 1740.

I8. Hans, their son, born April 22, I742.

Thus attests,

John Jacob Utzinger, Pastor.

No. 23. From DübeNdorff there left for Carolina in the YEAR 1734

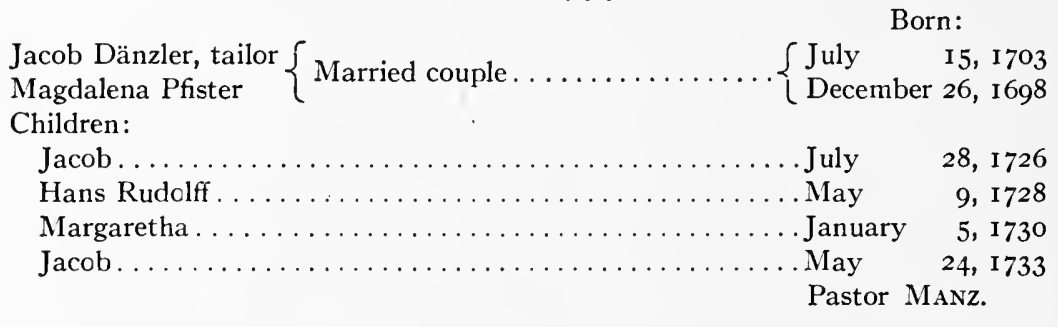

No. 24. DürnTEN

No one has yet gone from this parish either to Carolina or Pennsylvania. There are some indeed who wander about wretchedly as homeless people, thus a dismissed judge from Dürnthen, viz.: Hans Caspar Hotz. Also a certain Dänd- 
liker from Grüningen, who for several years had settled in the village and also had spent everything, he is with a wife and child.

From Ober-Dürnten a certain Keller from the parish Mur is also wandering about in misery as a wretched head of a family with a wife and six children. Then, a certain Letsch, with wife and child, but who still has means to maintain himself; he is a saddler by trade.

ZELLER, Minister.

\section{No. 25. List of those who left the Parish Dynhart for the New World}

Heinrich Bosshart, from Dynhart, born December 22, I695.

Anna Schaub, his wife, born November I2, 1694.

Children:

Kaspar, born October 2, 1718.

Heinrich, born December 26, I725.

This Bosshart with his wife and two boys left in 1734 .

Ulrich Brunner, from Aeschlikon, born February 8, I686.

Anna Ernin, his wife, aged 65 years.

Children:

Heinrich, born October 8, I7I9.

Rudolff Brunner, also Ulrich's son, born August 27, I713.

Child:

Elsabetha Geyer, his wife, born January I2, I7I 5 .

Hans Ulrich, born December I7, 174I.

These two households left together in 1743 .

Ulrich Huggenberger, from Wetzikon, born January 23, I698.

Magdalena Duttweiler, his wife, born July 7 , 1700.

This couple had no children and left in 1743 .

Ursula Sommer, Jacob Sommer's (deceased) daughter, from Aeschlikon, born March 24, I7I2, was in service at Stein and left with the above, in 1743.

Anna Ammann, Ulrich Ammann's daughter, from Wetzikon, born October 29, I7I3, served at Berg, the parish Dägerlen and left with several from this parish in 1743 .

These are the persons, who against all warnings left the parish of Dynhart, with the purpose of going to Carolina.

Dynhart, April Io, I 744 .

Attested by JoHn RudolfF BüEler.

On further inquiry it appears that also Anna Stapfer, the daughter of the deceased Hans Jacob Stapfer, from Sulz, born October 5, I704, left with several from Ellikon, where she served, without giving notification in the parsonage of Dynhart, in the year 1743 .

\section{No. 26. The Following Persons left the Parish Eglisau in JUNE, I 743 \\ Born Family}

I692 Ulrich Hartmann, turner, at the Steig, July 24.

I695 Anna Fehr, December 25.

Children:

1728 Anna Barbara, May 22.

1730 Heinrich.

1732 Hans Jacob, August ro.

1737 Anna Catharina, February Io. 
2.

I699 Hans Marthj, inn-keeper, boatman at the Burg, February 28. Verena Keiser.

I 7 I Hans Ullrich Sprenger, September I 2.

I7I6 Verena Schnetzer, December 26.

I679 Regula Utzinger, April 20. Deceased Rodolf Schneider's wife from Her son. Oberriedt.

I 7 I 2 Jacob Schneider, boatsman, February 26.

I7 7 Regula Hartmann:

Children:

I 740 Anna, August 2.

I742 Hans Jacob, February I3.

\section{5.}

1705 Jacob Keiser, January 28. Weaver at Oberriedt.

I 7 I Regula Braitter, April I5.

6.

I694 Fronnyk Keiser, October 27, Ulrich Bechtold's wife from Oberriedt. With two children.

I 724 Magdalena, November I9.

I729 Barbara, March 13.

I 7 I Johannes Jauschlj, at the Staig, March 2.

Ursula Meyer.

Rodolff Keiser, Marthj Keiser's (deceased) son at Oberriedt.

I 72I Elisabeth Meyer, Jacob Meyer's (forester) daughter at Seglingen, April I3. Total: 24 persons.

No. 27. List of Emigrants from 'the Parish Elgg for PenNSylvania AND CaRolina

I 737

Hansz Ulrich Hofmann, from Schottiken, baptized September I8, i 7 I 8.

I 742

Hansz Conrad Brunner, from Schottiken, baptized October I8, I 7 I I.

Anna Barbara Speker, baptized June 2, I 7 I 5 .

Same year

Hans Ulrich Vogler, from Elgg, glazier, baptized February I I, I 703.

Anna Maria Trachsler, baptized May 3I, I702.

Children:

Anna Magdalena, baptized August 8, I 728.

Hansz Heinrich, baptized April I I, I73I.

Caspar, baptized July $28, \mathbf{1} 737$.

Hans Ulrich, baptized April I 5, I739.

Hans Jacob, baptized April 19, I 74I.

I 743

Journeyed to Pennsylvania together with two persons from Veldheim, to claim an inheritance of $7500 \mathrm{fl}$. from their cousin Hans Ulrich Hagmann at the time in Germantown.

Rudolf Büchi, from Schottiken, Zürich, messenger's son, baptized December I, I 720 . 
Anna Barbara Peter, Hans Ulrich Peter's daughter in Schneit, baptized December 29, 1720.

Atque/eodem anno/alio Patriam quaerunt hub Sole jacentem.

(And in the same year there sought a fatherland cast under another sun):

Caspar Büchi, hatmaker, from Elgg, baptized December 3, I693.

Anna Barbara Hegnauer, baptized April 24, 1697.

Children:

Margaretha, baptized December I6, I725.

Heinrich, baptized November $17, \mathbf{1} 726$.

Anna Barbara, baptized August I3, I 730 .

Hans Jacob, baptized January 6, I732.

Caspar, baptized August I, I 734 .

Hans Ulrich, baptized April I I, I743:

The same year

Ulrich Büchi, from Elgg, a widower, baptized February 6, I698.

Daughter:

Susanna, baptized February I, I 728.

Sister:

Maria, baptized December 2, I 708.

The same year

Bernhard Keller, from Elgg, baptized December 6, I7II.

Lisabeth Büchi, baptized February I5, I 7 I I .

Children:

Joachim, baptized November Io, I737.

Lisabeth, baptized March II, 1739.

Susanna, baptized April I, I 742 .

The same year

Joachim Peter, from Gündliken, baptized September I I, I 704 .

Lisabeth Lieber, baptized September 26, I7 I I.

Children:

Elsbeth, baptized September 10, I 730.

Rudolf, baptized December 9, I732.

Joachim, baptized December I3, I733.

Melchior, baptized July I 5, 1736 .

Hugo, baptized October 20, 1737 .

Anna Barbara, baptized November 15, 1738 .

Anna Magdalena, baptized February 24, I 743.

The same year $\mathbf{1} 743$

Jacob Buchmann, from Schottiken, baptized March 22, 1696.

Margaretha Schwizler, baptized December 25, I698.

Children:

Jacob, baptized September 28, I721.

Hansz Ulrich, baptized July 26, I 723 .

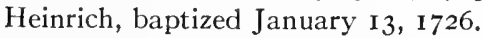

Salomon, baptized August 25, 1729 .

Anna, baptized August 24, I732.

Margaretha, baptized April II, I734.

Joachim, baptized June 30,1737 .

Hansz Conrad, baptized July Io, I740.

Total: 47 Persons.

Delivered in May, i744. By J. Conrad Wirz, Minister at Elgg. 
No. 28. List of those Persons who went from the Parish Elsau to Carolina and Pennsylvania, Anno 1734-I744

Date of Birth

I

Left for Carolina

Deceased Hans Ulrich Huber's sons from Rümiken:

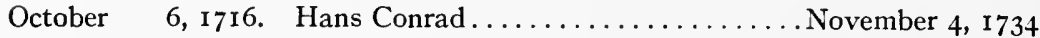

October I, I719. Samuel...........................

2

July 9, r699. Andreas Brüncker from Rümiken . . . . November 4, I734.

September 8, r695. Regula Herter, his wife.

Children:

July Io, I722. Hans Heinrich.

March 5, 1724. Hans Conrad.

April I4, I726. Hans Ulrich.

November 9, 1727. Jacob.

August 6, I73o. Maria Lisabeth; N.B. Died.

July 20, 1734. Abraham.

March 23, 1697. Salomon Ruckstul from Rümicken.....November 4, I 734 .

March 23, r682. Barbara Büchj.

Children:

November 30, I704. Joachim.

October 9, I707. Salomon.

July 14, I709. Hans Conrad.

September I7, I7I3. Cleophea.

March I3, I718. Barbara.

January 9, I724. Hans Heinrich.

June 21, 1727. Hans Ulrich.

N.B. We have heard that the first three sons, Joachim, Salomon and Hans Conrad changed their intention and stayed behind in Alsace.

4

Left for Pennsylvania

August I 8, I700. Melchior Ruckstul from Rümicken.

February 20, 1698. Margreth Egg, his wife.............July 4, I743. Children:

1737, baptized. Verena Marithi, spuria, child of Verena in Winterthur, and Schupisser in Oberwinterthur.

Elsau, April r6, I744. Attested: John Caspar Freüdwerler, Pastor.

\section{No. 29. The Following People have left Embrach for Penn-} SylvaNia AND CAROLINA

I. Hans Zollicker with wife and seven children.

2. Elsbeth Fäsi, Heinrich Zollicker's widow, with 2 children.

3. Kilian Zollicker with his wife and six children.

4. Heinrich Cappeler of Oberembrach, with one son and son's wife.

5. Rudi Cappeler's widow, Elsbeth Büchi, from Oberembrach.

6. Jacob Bachmann from Untermetterstetten and his wife.

7. Ulrich Huber, from Loch, with his wife and two children.

8. Jacob Bosserth, of Mülliberg, with his wife and four children.

9. Caspar Huber's (deceased), of Oberwageburg, son and daughter.

Io. Felix Bentz's two sons (Bentz, who was killed by accident).

II. Peter Bänningers son, Ulrich, of this place.

12. Hansz Conradt Heuszer, with his wife and three children. 



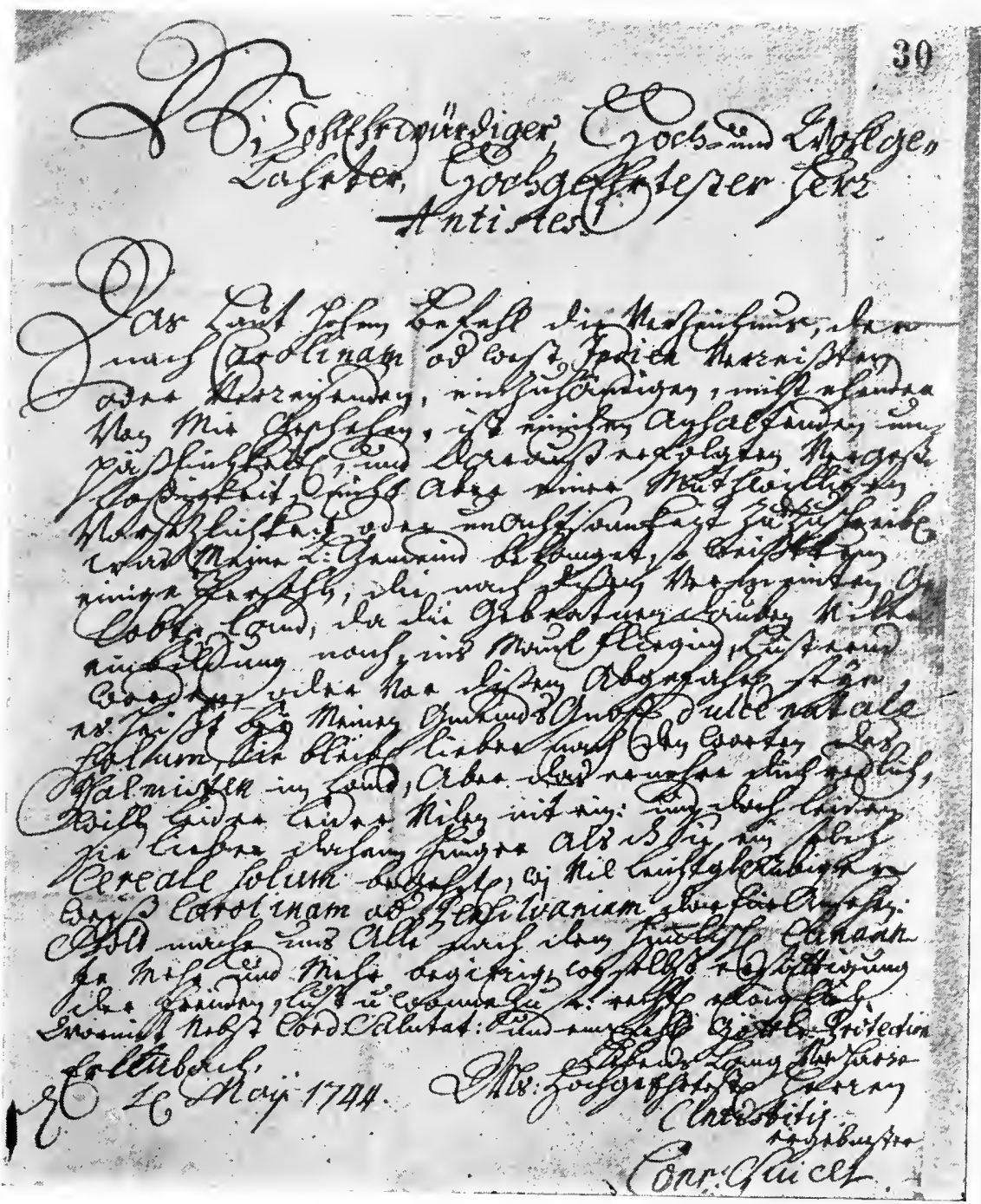

Reproduction of the Original List No. 30, Erlenbach, May i, 1744 
13. The wife of Bernet Wipfen who was killed by accident, with one child.

14. David Leimbacher, with his wife and three children.

15. Ulrich Huber, of Underwagenburg, with wife and 4 children.

I6. Rudolff Bosserth, of Mülliberg, with wife and 3 children.

17. Ruedi Cappeler's daughter.

I8. Hansz Heinrich Bosserth's, of Mülliberg, one son and daughters.

19. Catarina Meier, daughter of Hans Meier of Embrach, deceased.

20. Ursel Bosserth, daughter of Heinrich Bosserth of Mülliberg, who has disappeared.

21. The son of Jacob Bosserth ab der Stiegen, deceased.

22. Heinrich Krebser's, of Rottenfluh, son Rudolf.

23. Johannes, son of Jacob Krebser, deceased.

24. Jacob Bänninger, son of Ulrich Bänninger of Embrach.

Total: 73 people.

Received March 28. Sent the 3oth.

\section{No. 30. From Luffingen. (See Plate 2)}

In 7338 Hans Ulrich Meyer with his wife and two young children journeyed to Carolina. Because of my remonstrances no one has dared to do it since.

Most Honorable, Most Learned, and Most Revered Superior:

That I have not sooner, according to your command handed in the list of the people who have left or are leaving for Carolina or the West Indies, is due to certain restraining inconveniences and consequent forgetfulness, but not to stubborn insubordination or carelessness. As far as my parish is concerned, I do not know of a single person who has cherished a desire for this so-called promised land, where, according to some people's fancy, roast pigeons fly into one's mouth, nor one who has departed thither. My parishoners believe in the proverb "dulce natale solum" (Sweet is one's native land). They prefer to remain in the land, according to the words of the psalmist, but the making of an honest living, alas! alas! has not always proved true, and still they prefer to suffer hunger at home than to desire such a "fruitful land," as many frivolous persons believe Carolina or Pennsylvania to be. May God make us all long more and more for the Heavenly Canaan, where there is completeness of joy, happiness and bliss forever at His right hand. With heartfelt greetings, and committing you to divine protection, I remain, for the duration of my life, my Most Honorable Superior's humble servant Conrad Suicer, Pastor.

Erlenbach, May I, I 744 .

No. 3i. List of those Persons who went from the Parish of Fällanden to Carolina

I. Jacob Aepplj, born July Io, I70I, his wife Anna Fenner, born March 31, I705. Children:

Margreth, born December 5, I 728 .

Johannes, born August 16, I735.

2. Hansz Jacob Aepplj, born January 6, I704, his wife Verena Wetstein, born September 26, I 706 .

Child:

Rudolff, born September 25, I 735 .

3. Christoph Hauser, widower, born May I0, I69I, the daughters:

Barbara, born November 30, 1717 .

Anna Barbara, born May 2, I719.

4. Hans Rodolf Bodmer, born May I, 1692.

His wife, Regula Gachnang, born July 9, I703. 
Children:

Hans, born June 16, I 726.

Heinrich, born November I4, I 728 .

Cleophea, born June I 4, I733.

Regula, born April 8, 1736.

5. Hans Ulrich Bosshart, born March 25, 1717. Brothers, legitimate sons of Heinrich Bosshart, born March 23, 1721. $\}$ Jacob Bosshart.

6. Johannes Bachmann, George's legitimate son, October 4, I7I2.

7. Barbara Bosshart, deceased Jacob's legitimate sister, born February I 7, I7 I I.

The above persons all left Anno 1738 .

Anno 1743 there departed:

8. Heinrich Gachnang, born March 21, I7I 7 .

His wife, Susanna Fischer, born July 24, 1707 .

Their children:

Christoph, born September 27, 1739 .

Salomon, born November 5, I74I.

Fällanden, March 30, I744.

Written by JoHN FäsI, vicar.

\section{No. 32. Fischenthal}

Names of those families and persons from this parish who from 1734 till the present have been living in foreign lands.

I. Regula Brunner, widow of Heinrich Egli, ab dem Rohr, with six children, named: Hans Jacob, Caspar, Barbara, Anna, and Regula, as well as Maria, who was married to Marx Kägi. This couple is wandering about the country and no one really knows where they are. The mother, however, with the other children intended to go to Carolina, but came home poor; and will not be received by the parish until she can obtain the official permission to stay here.

2. Salomon Egli, a son of the above-mentioned woman, has been in Holland ior three years.

3. Abraham Zuppinger from Müllibach has also been in Holland for about three years.

4. Hansz Jacob Kägi from Lenzen hired out in Holland about two years ago.

5. Rodolff Bischoff from Wald has been in Holland for three years.

6. Hans Jacob Ryser from Leimaker has been in Holland for two years.

7. Hans Ulrich Schönenberger from Heussli has been in Holland for a year.

8. Jacob Kägi from Oberhoff has been in Holland for a year.

9. Hans Jacob Bischoff auf der Bodmen has a wife and four children, deserts them, and the children are put upon the care of the parish and are supported by alms or from the church property. Where this man is, no one knows. It has already been four years since he disappeared.

10. Hans Jacob Zuppinger, from Müllibach, has also been out of the country, no telling where, for four years.

This is the specification made, according to the official command, of those families and persons from the parish of Fischenthal who are residing abroad.

Fischenthal, April 7, 1744 .

Attested: S. Weiss, Pastor.

\section{No. 33}

Dorff. On May 15, I743, an unmarried man, named Martin Roth, aged 27 years, started from here toward Pennsylvania with 150 florins. He sent word from London that he hoped to arrive there safely, but, to my knowledge, there has since then been no further word from him. This circular I received at half 
past two in the afternoon and I am sending it with respectful greetings to Rev. D., Pastor in Flaach.

FLAACH. The past year three families left my parish: Jacob Fissler with his wife and two young men, Conrad Fehr with his wife and two children, and Conrad Gugler of Volken with his wife without children. But four families have decided to leave next week unless an official prohibition prevents them, which will be immediately reported to the District Governor (Kreis-Landvogt) at Andelfingen. We are sending the circular on the same day on which we received it. With greetings, Rev. D's vicar, Berg.

Berg. Anno I 738, the following persons left for Carolina: Jacob Bucher with his wife and three children,- -took about 15 florins with him. Also Jacob Meyer with his wife and four children,- -also took about 15 florins with him. Also Ulrich Schmid who took about 30 florins with him. Also Jacob Fehr, the weaver, and his wife who took about 15 florins with them. Also Catharina Egg, unmarried, born in Seen. These parties left in September of the given year $\mathbf{1 7 3 8}$, but no report of them has ever reached us. This circular is being sent as quickly as possible with respectful regards to the Pastor in Buch.

Bucr a/ Irchel. Eight or ten years ago there left my pa ish for Carolina, Heinrich Meierhofer, an unmarried man of 30 years, with about 30 florins. $\mathrm{He}$ is at present in Carolina in the service of Mr. Samuel Augspurger, a citizen of Bern. Thereafter Caspar Schurter with his wife, both 30 years old and with young children,--took with them 40 to 50 florins. Where they went we do not know yet. At present no more from here have any desire to start out. A year ago my son, Elias, vicar of Hengart, in a sermon to that purpose, tried to make the dangerous journey to Carolina distasteful by every conceivable and striking argument, and to prevent it, but he found a poor hearing with many. I received the circular March 26, at one o'clock in the afternoon and am sending it the following morning with greetings to the honorable pastor in Neftenbach.

\section{No. 34. Specification of those Persons who Emigrated from} the Parish of Glatfelden to Carolina

Parish Glatfelden.

1738

Parents:

Ages.

I. Heinrich Meyer................................

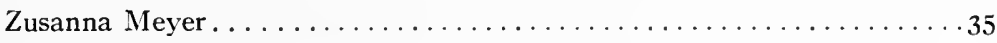

Children:

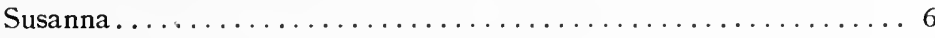

Lisabeth..............................

1740

2. Steffen Keller, deceased Hans' . . . . . . . . . . . . . . . . . . . 49

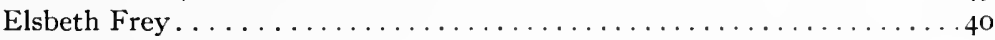

Children:

Salomea ............................... 20

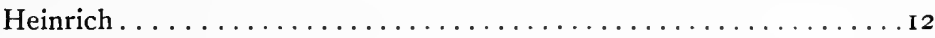

Hans Jacob........................... 6

Parents:

3. Brother of the above-mentioned Steffen Keller,

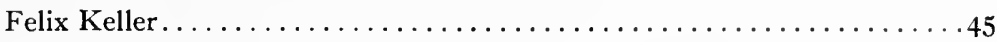

Vrena am Berg.............................. 
Children :

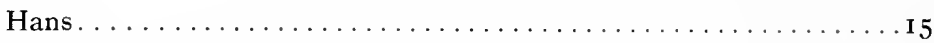

Vrena .............................. 2

Susanna ............................. 6

N.B. This Felix Keller has with him his mother, Margaretha Meyer (aged 75), wife of Hans (Meyer) deceased: also his unmarried brother, Caspar Keller (aged 38 ).

Parish Zweidlen.

I 740

Parents: Ages.

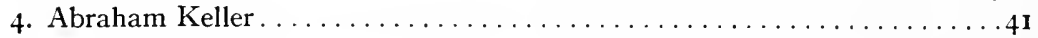

Margaretha Koffel. ............................ 39

Children:

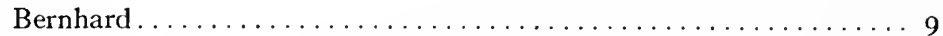

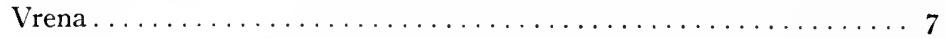

Barbara ....................... 5

Glatfelden.

I 743

Husband and Wife.

5. Hans Peter Lee. . . . . . . . . . . . . . . . . . . . . . . . . . .6o

Vrena Meyer..............................6o

6. Parents:

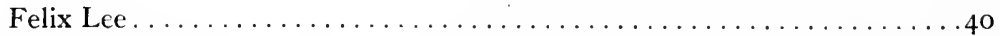

Vrena Martelerj............................... 39

Children:

Hans................................. 2

Anna................................. Io

7. Husband and Wife.

Hans Jacob Huszer. . . . . . . . . . . . . . . . . . . . . . . . 20

Madalena Azenweiler. . . . . . . . . . . . . . . . . . . . . . . . 28

8. Parents:

Caspar Glatfelder . . . . . . . . . . . . . . . . . . . . . . . 36

Lisabeth Lauffer. . . . . . . . . . . . . . . . . . . . 34

Children:

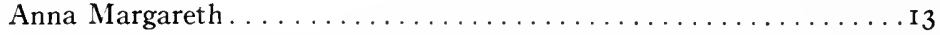

Anna ... . . . . . . . . . . . . . . . . . . . . . . . . I I

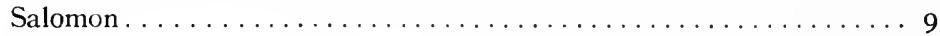

Johannes. . . . . . . . . . . . . . . . . . . 7

N.B. Has with him his father-in-law,

Hans Jacob Lauffer. . . . . . . . . . . . . . . . . .

Parents: 1743

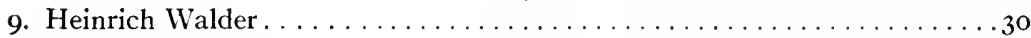

Dorothea Lauffer . . . . . . . . . . . . . . . . . . . . .

Io. Husband and Wife.

Hans Peter Glatfelder. . . . . . . . . . . . . . . . . . . . . 45

Salomea am Berg. ............................ 40

N.B. Has with him his brother Felix Walder, unmarried . . . . . . . 25

Children:

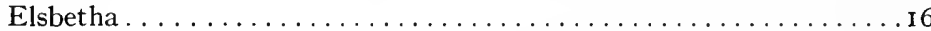

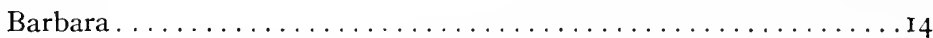

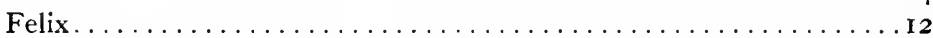

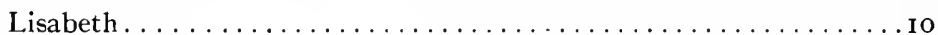

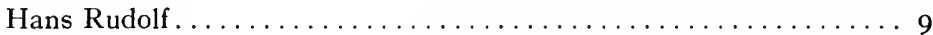

Johannes. . . . . . . . . . . . . . . . . . . . . . 4 


\section{Zweidlen.}

II. Parents:

Hans Schmid . . . . . . . . . . . . . . . . . . . . . . . . . .

Margaretha Schüz................................

Children:

Caspar.............................

Johannes. . . . . . . . . . . . . . . . . . . . . . . . .

Reinszfelden.

Hans Ulrich . . . . . . . . . . . . . . . . . . . . . . . . . 4

12. Heinrich Guth .................................. 28

N.B. His wife, Anna Scherrer, with whom he lived until that time in the parish of Neftenbach is at present trying to obtain a separation from him from the Matrimonial Court.

Total Number of persons- 53 .

\section{No. 35. From the Parish Gossau there have left for Carolina}

Anno I734. From Bertschiken:

Rudolf Walder, baptized April 10, I698, with his wife, Anna Stuzin and little son, Jacob, aged 4 years, took money with him, 50 pounds.

\section{Anno 1739. From Ober-Ottiken:}

Jacob Zollinger, baptized April 27, 1697, with his wife, Lisabeth Frey:

Children:

Anneli, aged ro years.

Casperli, aged 6 years.

Andres, aged 4 years.

Babeli, aged 2 years.

He raised money on his farm and took with him 500 pounds.

Attested: John Heinrich Däniker, Pastor.

No. 36. List of those Persons from the Parish of GreiffenSEE who, from the year I734 until this present year I744, either have emigrated to Pennsylvania or have intended to go there, but are staying at present in other places or have returned home.

Anno I734, in October, Margaretha Vogel, daughter of the late Heinrich Vogel, the mason, left this parish for Pennsylvania, being then zo years of age. She is said to be there at present.

Anno 1738. Hans Jacob Wolffensperger, at that time 34 years old, and his wife, Susanna Danni, 30 years old, with three children: Elsbeth, then 7 years old, Maria, then 4 years old, and Margaretha, then $3 / 4$ year old. This family left our parish in August of that year. Went as far as Basel, from there back to Aarau, where they stayed almost two years. Since then they have been living again in our parish.

Anno 1738. Heinrich Drachssler, the hedge-maker, then 23 years old, and his wife, Catharina Danni, then 24 years old, also left here in August of the specified year, went as far as Basel, from there back to Aarau where they stayed not quite a year, but since then they have been living again in our parish.

Anno 1743. Johannes Bleuwler, son of Hans Heinrich Bleuwler, the butcher, 28 years old, left here in May. Went as far as Basel, where he is now working in a mill, as journey-man miller. 
Felix Bleuwler, brother of the above, 20 years old, left here in May, went as far as Basel and has been since then in the French army.

Hans Jacob Brauch, son of Hans Conrad Brauch, 22 years old, left here in May, went as far as Basel and came back from there in a few weeks to our parish.

Hans Conrad Burckhard, son of Hans Conrad Burckhard, the scabbardmaker, I4 years old, a very poor boy; the three people above-mentioned allowed him to go with them to Basel (because he could not find a master hereabouts), where he has been living ever since. According to a written report which we have received, he is behaving himself very well and, through the kindness of some compassionate people there who have interested themselves in him, has been apprenticed for five years without apprentice-fee, to a ropemaker, to learn the trade.

Anno I743. Hans Jacob Wüest, the son of the district judge, Hans Conrad Wüest, 22 years old, learned the locksmith's trade and gave out that he was going travelling as a journeyman, but left Basel in May with some fellow countrymen to go to Pennsylvania, and is said to have married a woman from the Oberen Strass, who once stood in the pillory in Zurich.

Anna Wolfensperger, daughter of Jacob Wolfensperger, the joiner, 28 years of age, went from here to Basel in May and started from there with some fellow countrymen to go to Pennsylvania and is said to have married a fellow from Affoltern in the Albis.

Greiffensee, April I, I 744. Johann Jacob Orell, Pastor at Greiffensee.

There was omitted above: Anno 1738. Magdalena Drachszler, daughter of Heinrich Drachszler, the hedge-maker, deceased, then 17 years of age, travelled from here to Basel in August with the intention of going to Pennsylvania, but is said not to have gone on from there, but to be wandering around elsewherenow here, now there-like a good-for-nothing woman without reporting definitely where she is at present.

\section{No. 37. Specification of those People who went from the Parish Husen am Albis, to Carolina and Pennsylvania}

Jacob Ringker, born August 16, 1707, son of Captain Werner Ringker, deceased, of Husen;- to Carolina September I, I74I.

Heinrich Grob, born May 23, I723, son of Julius, of Hirtzwangen;- - to Carolina July $24,1742$.

Sergeant Heinrich Hitz, from the Bäuder-Albis, born July I I, I697, with his wife, Elsbetha Frick, of Knonau, born April I8, I7II, and four children: Verena, born March 16, 1727, Adelheid, born February 10, I 732, Heinrich, born September I3, I733, and Anna, born May II, I738; - to Pennsylvania.

Heinrich Lier, of Ebertschwyl, born August 7, 1707, with his wife, Verena Suter, also of Ebertschwyl, born October 6, I705, and little son, Beat, born September 27, 1733. Both parties to Pennsylvania April 29, I 743.

Sergeant Johann Conrad Schmid, son of the mason, of Heist, born June 24, 1717, with his wife, Susanna Hügi, also of Heist, born December 6, 1716, and three children: Hans Jacob, born September I7, I74I, Hans Rudolf, January 6, I743 and Regula, March I, 1744; - to Pennsylvania April I, I 744 .

April 27, I744.

Attested: Johann Jacob Hirtzel, Pastor. 
No. 38. Anno i 743, From the Parish Henkartt, with the Knowledge and Consent of the Two Honorable GovERNORS OF KYBURG AND ANDELFINGEN, the following families and persons journeyed to the new-found land-I do not know whether to Carolina or to Pennsylvania.

I. Jacob Frauenfelder, shoemaker, called Gabriel, baptized October 30, I707, with his wife, Elsbetha Meyer von Buech, far advanced in pregnancy.

N.B. He was the instigator and the seducer of the others from the County.

2. Deyes Frauenfelder, brother of the above, baptized March I 7, I 705.

Verena Schaub, his wife, baptized February I 8, I 703.

Children:

I. Mathias, baptized March II, I732.

2. Jacob, baptized June 23, 1733 .

3. Ursala, baptized July I 8 , I 734 .

4. Johannes, baptized January 29, 1736 .

5. Barbara, baptized September 8,1737 .

6. Heinrich, baptized November I 5, I739.

7. Conrad, baptized October 8, I $74 \mathrm{I}$.

They took all these seven children with them. This family resided in the Estate.

3. Jacob Frauenfelder, called Gräzli, baptized December 20, I705.

Anna Weyer, his wife, of Seen, baptized November 9, I 7 or.

\section{From the County}

Children:

I. Anna, baptized January 22, 1732 .

2. Barbara, baptized May 20, I734.

3. David, baptized October I6, I735.

4. Elsbetha, baptized June 16, I 737 .

5. Hans Conrad, baptized September I0, I 74I.

Took them all with them.

4. Mathias Frauenfelder, son of Jonas, baptized December Io, I 7 I 2 .

Barbara Müller, of Hettlingen, baptized August 24, 1710. Far advanced in pregnancy.

N.B. He sent back from London, where his wife recovered from the birth of a daughter, a lamentable letter, in which he could not write enough concerning how miserably they had been deceived, warning everyone against this journey. Threatens to come home again, as soon as it is possible.

He resided in the Estate.

These four families emigrated in June, but the two following ones in August. Nothing seemed so sad to me as this obstinate, unscrupulous emigration of these heartless parents with so many innocent little children. I was seriously ill at the time or I should have taken desperate measures to prevent the same, and would have sent the Elders immediately to the Honorable Governors on their account, but all was in vain, and my sickness was made all the more bitter for me,- and these people were as if bewitched and desperately resolute, for most of them were poor and could hardly get together sufficient money for the journey; and, what was worst of all, in their answer to our warnings they laid the blame-indirectly, indeed-upon our gracious masters. Note the following: If this were true and our gracious masters had allowed so many of their subjects to emigrate from their country, and if the aforesaid lamentable letter and other sad reports had not reached the country, and become known, a good many might have decided to emigrate. 
Each of these six families has an official certificate of baptism from the pastor of the parish with them. The first four were written in my own hand the last two in the schoolmaster's hand, but signed by me and with these two words added: sponte et audacter (voluntarily and rashly).

5. Hans Jacob Frauenfelder, called Pfeiffer, baptized November 15, I 7 I I.

Anna Frauenfelder, his wife, baptized July 29, I $7 \mathbf{1} 2$.

Children:

I. Ursala, May 27, I 736.

2. Pantaleon, March $4,1738$.

3. Barbara, July I7, I742.

6. Jacob Frauenfelder, son of Gabriel, the tailor, baptized December 3, I 7 I 3 .

Elisabeth Brätschger of Aesch, born 1709.

Children:

I. Barbara, baptized March I8, I736.

2. Hans Heinrich, baptized November 24, 1736 .

3. Elsbetha, baptized April Io, 1740.

4. Anna, baptized September 23, I742.

Anna Frauenfelder, a respectable young woman, unmarried, sister of Jacob Frauenfelder, above-mentioned, baptized March 29, I7I6. These two families-Nos. 5 and 6-resided in the County.

In all six families, four from the County, two from the Estate. Persons-32.

Moreover, under my predecessor, deceased Anno I739, there left here for Carolina; Felix Frauenfelder, son of Felix from the monastery, baptized November 13, I70I, and his wife, Elsbetha Mäder, from Schleittheim in the District of Schaaffhausen, baptized April I4, I 701, with five children, including four boys, the oldest about ten years old.

Henkertt, March 3I, I 744.

Leonhard Holzhalb, Pastor.

No. 39. The Families and Persons from the Parish of HexKERTT, residing abroad or wandering about here and there, March 3I, I744.

I. Adam Müller, baptized December 27, I672, widower since July 19, I733; resides in Schaaffhausen on a vine-raising estate.

Children:

I. Ursula, baptized December 29, I 7 I3.

2. Hans Ulrich, baptized July 25,1715 . They are all said to have been

3. Barbara, baptized December 22, I 7 I 7.
4. Rodolff, baptized May 23, I720.

2. Adam Müller, son of the above, baptized January I, I705.

Verena Süesstrunk of Wisendangen, March I0, I7 I6. Married April 26, I 735. They also resided in the District of Schaaffhausen, but they are said to have settled permanently in the District of Basel.

3. Heinrich Weni and Ursala Chym of Schlatt. The former's wife died last year at Schaaffhausen on the vine-raising estate which he had leased; and he returned this year again to this parish with honorable testimonials and considerable means, aged 78 years.

4. Deyes Steinmann, a shoemaker, baptized October 4, 1687, was married in the margravate of Weil, an hour's distance from Basel, to Sara Seiffert, February 2, 1717. According to a letter which we have received, he died September 3, of last year, and his death has been published here. He leaves behind his wife and four children, two sons and two daughters, of whom the one son and the one daughter are already married. The children are called:

Anna Maria, Lorenz Simeon, Johann Conrad. 
5. Hans Jacob Frauenfelder, smith, baptized February 14, I698. He, it appears, disappeared suddenly and since then no one has heard the slightest word from him. His wife, Anna Blickenstorffer, baptized August 20, I699, wanders about the country with her daughter, Margaretha, baptized January 16,1734 , an illegitimate child, conceived in adultery, and spends much of her time in the districts of Baden and Bern. The son, Hans Ulrich Frauenfelder, baptized March 29, 1.722, also wanders around begging. Hans Jacob Frauenfelder, son of the younger Graz, baptized January 8, I69o. Joseph Frauenfelder, brother of Gräzli, baptized December 6, i 7 I I.

Hans Conrad Frauenfelder, son of Baschi, baptized January 30, I7or.

Hans Conrad Steiner, brother of Seepe, baptized June I4, I705.

\section{Unknown}

Also some people 60-70 years old or more, some of them discharged soldiers, some of them vagrants, of whom nothing is known, Baschi, David, Hans Conrad, Jacob, Isaac Frauenfelder.

Hans Ulrich Frauenfelder, son of Joseph, deceased, is living in Strassburg. He was here in this country two years ago, living with a woman whom he is since said to have married. Baptized May 4, I7 I9.

Hans Jacob Frauenfelder, called Weber, baptized August I6, I696.

Barbara Frauenfelder, baptized November I4, 1797.

Children:

1. Hans Ulrich, baptized October 7, I 725 .

2. Anna, baptized April 4, I 728 .

3. Barbara, baptized January I, 1730 .

4. Hans Jacob, baptized March 21, I734.

5. Hans Peter, baptized July I3, I 738 .

Sold his property here and established himself with his family in Buesingen.

There are also three or four women missing who are said to have gone to the lowlands, or to be wandering about elsewhere, or to be in the realms of the dead. At any rate, we do not know anything about them.

The soldiers, who are at present serving in Holland or elsewhere, have been listed in another place.

Leonhard Holzhal B, Pastor.

\section{No. 40. List of those Persons who have gone to Carolina from the Parish of Hedingen, Anno I 743}

I. Barbel Hunn, wife of Heiri Schmid, deceased, from the District of Bern.

Children:

Maria, born February I4, I 723.

Heiri, born September 14, I 727 .

Tomas, born June 23, I733.

With them went Uli Stähli, born January 9, I 706. He is a poor stupid fellow, good for nothing.

Also

Catri Hubschmid, daughter of the miller at Hedingen, born 1700. Also

Elseli Hedinger, daughter of Heiri Hedinger, born December I5, I720.

2. Heiri Meili, son of Heiri, went with his wife and children either there or to Pennsylvania. Many years ago he sold all that he had in Hedingen and since then $h$ as not been living in Hedingen, but in Maschwanden with his wife and children, so that he should be reported from Maschwanden.

Attested: Johann FäsI, Pastor. 
No. 4I. In Answer to the Official Command which I received from the Honorable Dean Fäsi at Hedingen, to give an Account of the Persons from this Parish of Rifferschwúl who have gone to Carolina and Penssylvania, I Report the Following to the Honorable Deax:

\section{Oberschweil}

The first left April 28, 1739, namely:

Johannes Schleipffer, baptized January 8, I7I 9 .

Johannes Bär, born January 3I, I 723 .

Elsbeth Bär, born August 27, 1719.

Bat. Rudolff Bär, born May I4, I7I9.

Hans Heinrich Bär, born December II, I 720.

Rudolff Bär, born May 17, I 722.

Hans Jacob Huser, born February 9, I 716 .

\section{Under-Rifferschweil}

Hans Jacob Widmer, born December 6, I 722.

Anna Bär, born October I3, I 7 I 5 .

Johannes Wäber, born April I4, I720.

Ulrich Wäber, born May I2, 1720.

\section{In August}

Heinrich Weber, born October 6, I7I 5 .

Anna Urner, born November 6, 1718.

Jacob Weber, born December 30, 1725.

There also left in 1743 in May:

Jacob Frick, born August 22, 1697.

Verena Bär, born July Io, 1718.

\section{Also from Ober-Rifferschweil}

Henrich Schleipffer, born May 17, I705.

Also his wife, Anna Grob, born August I, 1706.

Also their children:

Jacobli, baptized in Meria, in Flanders, Anno 1735.

Cathri, born January 20, 1743 .

Also from Under-Rifferschweil, A pril 1, 1744:

Henrich Urner, born June 10, I 702.

His wife, Anna Näff, born January I4, I694.

Their children:

Verena, born December 17, 1730.

Johannes, born August 7, 1735 .

\section{No. 42. Herrliberg}

The following left for Carolina in 1743 . Before this there were none. Born.

1704. $\left\{\begin{array}{l}\text { Rudi Wy-man. } \\ \text { Dorothea Sennhauser. }\end{array}\right.$

Children:

I721. Elsbeth.

1723. Barbara. 
I725. Jacob.

1729. Verena.

I732. Heinrich.

1735. Hans Heinrich.

Parents:

I 705. Heinrich Kölliker.

I 704. Rägula Brätscher.

Children:

I732. Antoni.

I 734. Heinrich.

I 736. Anna.

I 739. Susanna.

1742. Hans Caspar.

\section{From Berg}

Father:

I702. Heinrich Haab (Name not entirely legible.)

Children:

1727. Rodolf.

1732. Hans Rodolff.

Parents:

I702. Heinrich Hermetschwyler.

r 7or. Barbara Erzinger.

Children:

I726. Anna.

I728. Barbara.

I73I. Elsbeth.

1734. Jacob.

Conrad Ziegler, Pastor.

(Signature added in modern hand-writing.)

\section{No. 43. Hinweil}

From this parish there emigrated Anno 1743, with the intention of going to Carolina:

Caspar Honegger, from Unterbach, baptized February 26, I 708.

Anna Schneider, his wife, baptized July 4, I 706.

With three children $\left\{\begin{array}{l}\text { Marx, baptized February I8, I } 733 . \\ \text { Caspar, baptized April I 8, I 734. } \\ \text { Hans Jacob, baptized January I, I } 736 .\end{array}\right.$

He took about 160 florins in money with him since his brothers bought him out about five years ago for 180 florins.

Hinweil, April 7, 1744 .

Johann Ludwig Meyer, Pastor.

\section{No. 44. Hittnau}

Honorable, Learned, Highly-Revered and Gracious Dean:

In accordance with an official order, I am to send to the Honorable Dean a report of those persons from this parish who have gone to Carolina, in order that it may be sent to the official board. I am glad to be able to do this in "three words," as they say, since there is only one married couple:

Heinrich Zwik, tradesman, from Oberhittnau, born November 3, 1709, and Anna Rüegg, born in Wollnau, in the parish Bauma.

I have to report that they were married Anno I737, and are still without children. These people became so rich from the shop-keeping that they set up, 
that they made a great pile of debts, which yield their creditors only the trouble of looking after them. And they knew how to craftily conceal their design and to secretly carry it out, so that they could sell their remaining possessions and their household belongings with the plausible excuse that they must have money for the Whitsuntide Fair at Zurzach (about a year ago); with which excuse they exacted payment of their outstanding debts, as far as possible,-from some they got but a little. So they escaped with considerable money without letting anyone know, and their departure was not noised abroad until some time after they had gone, when they were probably already safe in Holland.

That is all that I can say concerning the emigration from our beloved parish. I commend this notification to the Board and the Honorable Dean and my humble self to their continued favor. Committing you to the protection of Heaven and of Our Saviour, in dutiful submission,

The Honorable, Highly-Learned, and Gracious Dean's humble servant,

Hittnau, April 1, I 744 .

$$
\text { HeINRICh Fäsi, Pastor. }
$$

\section{No. 45. From the Parish Hombrechtikon}

Caspar Muschgg from Brauslen, who formerly worked at Wollishofen, unmarried, left for Carolina Anno 1734 in October. He appeared before the Magistrates of the Estate Stäffen and acted against their advice. No one else so far as I know. No one from Stäffen has gone to America.

\section{No. 46. Horgen}

From this cherished parish there left last year for Carolina or Pennsylvania:

1. Hans Jacob Grundel, son of Jacob auf dem Bergli, baptized November I4, I719, the son of a poor man who had worked as a hired hand.

2. Jacob Sträuli, son of Caspar deceased, from Käpfnach, baptized December 24,1724 .

3. Heinrich Stünzi, son of Marx, the tile-maker, from Käpfnach, baptized August 22, I7I9.

Horgen, April 2, 1744.

Johann Keller, Pastor.

No. 47. From the Parish Illnauw the persons below described left for the so-called new-found land during the last few years:

7. Hanss Wezstein, wheelwright, from Kemleten, They left Anno I 737 with five aged 38 years.

Anna Frauenfelder, his wife, aged 36 years.

7. Conradt Denzler, from first, aged 37 years.

Anna Wezstein, his wife, aged 35 years. children, of whom the oldest was 6 , the youngest $3 / 4$ year.

They left with the above, also with five children, of whom the oldest was 6 , the youngest I year.

5. Jacob Graaff, of Rykon, left with wife and three children, of whom the oldest was 7 , the youngest 3 years, Anno 1738 .

5. Margaretha Keller, widow of the schoolmaster, of Ottikon, aged 34, left Anno 1738 , with four children; the oldest 15 , the youngest 4 years.

4. Felix Widmer, of Ottikon, aged 36 years. They left Anno I743 with two

Barbara Berüther, his wife, aged 40 years.

children, the oldest $81 / 2$, the youngest 4 years.

5. Jacob Wägmann, of Rykon, aged 36 years. They left Anno 1743 with three

Dorothea Haffner, his wife, aged 34 years. children, the oldest $6,^{\circ}$ the youngest 2 years. 
5. Mathias Frauenfelder, of Rykon, aged 45 years.

Anna Trindler, his wife, aged 50 years.

2. Hanss Würgler, of Rykon, aged 2 I years.

Verena Morff, his betrothed, aged 20 years.

3. Vrena Brändtlin, aged 22 years.

$\left.\begin{array}{l}\text { Regula IVägmann, aged 3o years. } \\ \text { Anna Hindermeister, of Effretikon, aged 40 years. }\end{array}\right\} \begin{gathered}\text { Of } \\ \text { Rykon }\end{gathered}\left\{\begin{array}{l}\text { married women } \\ \text { left Anno I743. }\end{array}\right.$

I. Barbara Schlumpf, of Horgen, aged 23, whose husband, Caspar Windsch, with her knowledge and consent entered the army for service in Holland $174^{2}$. She went back to her relatives at Münch-Altorff, where she became unfaithful to her husband and was made pregnant by another man, with whom she departed, Anno I743, with her father's help. From the ship in Zürich she sent her legitimate little son back to his poor grandmother in Horgen. Total 44 persons, including 25 children.

Illnauw, April 2, I744. Attested: Balthassar Peyer, Pastor.

\section{No. 48. List of those Persons who have left the Parish Kloten for Carolina}

\section{KLOTEN}

Anna Kern, wife of Jacob Brunner, with two children, after having faithlessly forsaken her husband, went with Heinrich Götschi to Carolina.

Jacob Brunner departed with the daughter of his cousin, Stüdli, of Basserstorff, whom he had made pregnant and with whom he had begotten an illegitimate child. Because the marriage-court refused to sanction their union they emigrated. He was 44 years old. He left behind in the parish five children, two sons and three daughters, who have fallen as a great burden upon the church and the parish for support.

Hanss Kleinpeter's son, by trade a carpenter, 24 years old, went to Carolina two years ago with people from IVallissell.

\section{OPFIKEN}

Felix Wismann, born June 19, I707, and Verena Foster, born November 26, I707, left with their child, Anna, born I740, with the people from Wallissell two years ago.

Barbara Eberhardt, daughter of Felix Eberhardt, the cooper, of Opfiken, born May 22, 1707, emigrated nine years ago.

\section{No. 49. List of those Persons who have gone from time to time from the Parish Kronau to Carolina and \\ Pennsylvania}

\section{To Carolina, I 739}

Heinrich Walder, son of the assistant magistrate, deceased, aged 32 years. Is said to have died on the journey.

Heinrich Sytz, son of the village watchman, aged 34 years.

Anna Walder, his wife, aged 30 years.

Heinrich Sytz, Jr., brother of the above, aged 24 years.

Caspar Frik, son of Ulrich, aged 3 I years, is said to have died.

Veronica Hitz, his wife, aged 32 years.

Anneli Frik, their little daughter, aged I year, is also said to have died. 
Johanes Frik, brother of the above, aged 20 years.

Ursala Frik, daughter of Caspar, aged 2I years.

Rudolf Frik, son of Felix, deceased, from Utenberg, an estate in the parish of Knonau, aged 29 years.

Anna Barbara Frik, daughter of Heinrich, from Utenberg, aged 24 years.

Left for Pennsylvania, May i, I743

Leonhard Walder, of Knonau, aged 37 years.

Anna Weiss, his wife, aged 39 years.

Their children:

Hanss Jacob, aged 16 years.

Anna, aged 13 years.

Hans Jacobli, aged 9 years.

Vreneli, aged 7 years.

Dorotheli, ten weeks old.

Elssbeth Frik, daughter of Ulrich, aged 39 years.

Anna Frik, her sister, aged 32 years.

Anna Sytz, daughter of Heinrich, aged 21 years.

Regula Sytz, daughter of Heinrich, deceased, aged 30 years.

Anno I 744, April I, at 9 o'clock at night there left secretly without the knowledge of the Honorable Governor or of the pastor.

N.B. Barbara Niehvergelt, wife of Heinrich Sytz, whose husband is still alive and 56 years old. She, his disloyal wife, is 43 years old.

Hanss Jacobli Sytz, her 9 year old son.

April 6, I744.

This is attested by Christophel Zregler, Pastor at Knonau.

No. 50. Specification of those Persons who Emigrated from KüSSNaCht FOR CAROLINA, ANvo I 743

From the Küssnachterberg, from the Hoch-Rüti Born.

Elsbeth Tobler, wife of Hans Erzinger, deceased................... 679

Children:

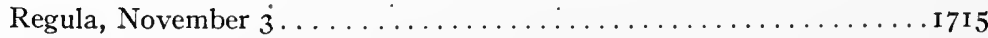

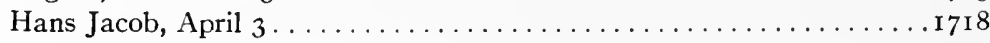

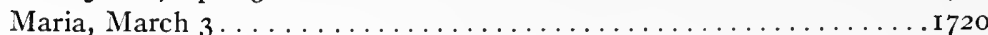

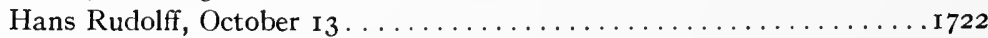

From Küssnacht

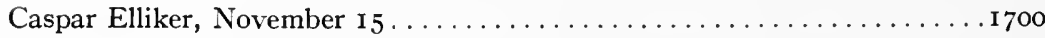

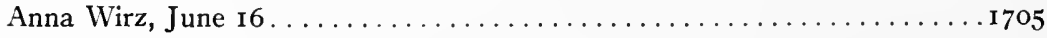

Children:

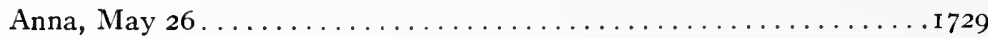

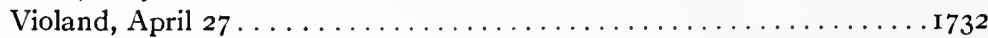

Caspar, January ro............................... 734

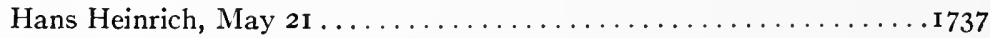

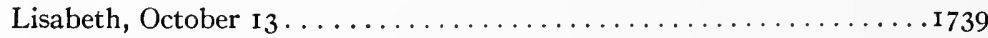

With him is his brother-in-law, Jacob Wirz, April ıo............... 67 r

Johannes Gimpert, September 28 . . . . . . . . . . . . . . . . . . . . . I699

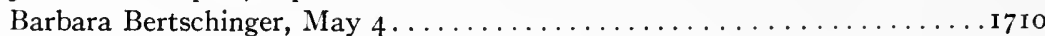

Children:

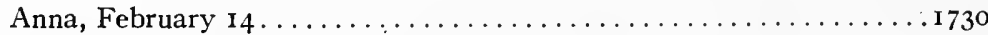

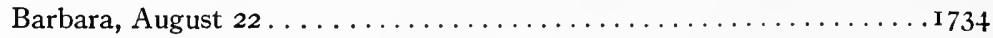

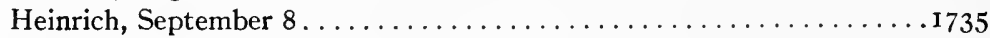

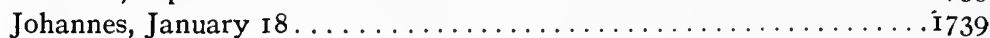

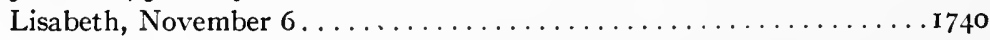


These went as far as Basel where the father entered the French service. The mother came back with the children and since the community would not receive her, she left the children in the parish and went away again.

Anna Wirz, who was divorced from Conradt Meyer, born January 15, I7I4. She is said to be in Basel.

Salomo Werder, son of Bernhardt Werder, deceased, born January 2, 1724. He went to Holland and came back again.

This is attested in accordance with the official command by

\section{H. Arminger.} Indies.

Note on the back: From the parish of Stäffen no one has gone to the West

From the parish of Männedorf no one.

Probably no one has left from these parishes since I have received no report in answer to my repeated requests.

No. 5i. List of those People who went from the Parish of Lindau to THE SO-CAlled New-Found LaNd

1738

Joachim Häussli, of Winterberg.

His wife, Elsbeth Ochssner.

Children:

Jacob, aged about ten.

Heinrich, born October 27, 1736.

In the same year:

Sarah Bläuler, widow of Jacob Keller, deceased, of Winterberg, with her son, Heinrich Keller.

Hans Felix Widmer, shoemaker, of Lindau, born September 6, I696.

His wife, Elsbeth Bänninger, in October, I 708.

Children:

Jacob, born February 27, 1725 .

Elssbeth, October 24, I 728.

Margaretha, June i 8, I 730 .

Kley-Jacob, October 12, I 732.

Elisabeth, December I9, I74I.

In the same year:

Hanss Kuhn, of Graffstahl, aged 52.

His wife, Barbara Dentzler, aged 53.

In the same year:

Hans Ulrich Wägmann, of Dagelschwangen, January 2, I699.

Anna Huber, his wife. In October, I702.

Children:

Barbara, December 9, I 726.

Heinrich, April 3, I 728 .

Hans Jacob, April I4, I 730 .

Anna, January I, 1732 .

Hans Caspar, November I8, I 733 .

Margaretha, September 20, I737.

These last were living on a feudal estate in Mur, from whence they emigrated.

The first two families went to Carolina, I am told, the last three to Pennsylvania.

Lindau, April I, i744. Attested: Johann Heinrich Ulrich, Pastor. 
No. 52. List of those Persons who have left the Parish of Marthalen for Carolina since I735 OR Who Have DECLARED THEIR INTENTION TO GO THERE

\author{
September 24, 1738
}

Hans Ulrich Binder, guide, baptized October 23, I698

Magdalena Mökli, his wife, October 20, I7oo.

Children:

Hans Ulrich, July II, I 728.

Barbara, November I9, I73I.

Theopel Binder, carpenter, October 9, I698.

Barbara Leüw, his wife.

Children :

Elsbeth, stepdaughter, January 9, 1727.

Hans Heinrich, January I, I73I.

Hans Ulrich, March 14, 1734 .

Hans Ulrich Mantz, Sprungen, January 20, 1697.

Anna Bachmann, his wife.

Children:

Anna, November 9, I 732 .

Hans Jacob, October 3I, I734.

Hans Ulrich, October 6, I 737 .

Jacob Binder, carpenter, June 28, I696.

Ursula Spallinger, July 17, 1695.

Children:

Magdalena, April 25, 1728.

Rudolff, May I3, I 73 I.

Susann, July 30, 1734 .

Conrad Mantz, Sprungen, September 3, 1699.

Magdalena Ritter, his wife, July I \&, I700.

Children:

Barbara, July I, I 724 .

Magdalena, February I3, I729.

Margreht, October 9, I 73I.

Hans Jacob, March 27, I734.

Anna, July 31, I 735.

Verena, March 9, I738.

Single Persons

Johannes Wipf, saddler, June I7, I694. Leaves behind a wife and one son.

Heinrich Spallinger, unmarried, April 4, I717.

Johannes Mökli, unmarried, October 8, I7I4.

Barbara Wipf, daughter of Georg, deceased, unmarried, September 25, I7 6 .

From all those who left Anno I 738 not the slightest reliable report has reached

Marthalen as to where they are or whether they are still living.

\title{
Anno 1743
}

Heinrich Wipf, wheelwright, September 25, 1692.

Anna Dietrich, his wife.

Children:

Elsbeth, March Io, I 726.

Hans Jacob, September 25, I 735 . 


\section{Anno 1744}

Georg Spullinger, carpenter, January 21, I696.

Margreht Sägenmann, his wife.

Children:

Anna, December 29, I 728.

Barbara, May 27, I730.

This woman came back last week with the children and says that the man was taken by the soldiers down in Basel.

Hans Jacob, October I I, I 739.

The two families who left Anno $43 \& 44$, gave out first that they intended to go to Carolina, then to the Palatinate, then to Alsace, so it is uncertain where they did settle.

Reported by Korrodi, Pastor at Marthalen.

\section{No. 53. List of those Persons who went from the Parish} of Mur to Carolina

Parents:

Anno 1738 there emigrated from Mur

Hans Jacob Zürcher, baptized June I6, I692.

Anna Schmid, of Grüningen.

Children:

Hans Ulrich, baptized August Io, I7 I 7 .

Elsbetha, baptized October 3, I7 18 .

Leonhardt, baptized June 5, I723.

Conrad Aeppli, son of Jacob Aeppli, deceased, baptized February 7 , I 700 .

Hans Aeppli, son of Jacob Aeppli, baptized March 4, I 708, unmarried.

\section{From Esch}

Caspar Kunz, son of Conrad Kunz, deceased, baptized October 16, I703.

Rudolff Egg, son of Hans Rudolff Egg, deceased, baptized June 7, 1705 .

Felix Meyer, with his wife.

\section{From Ebmattingen}

Anno 1743 , in May there emigrated

\section{From Mur}

Parents:

Heinrich Aeppli, baptized October 23, 1692.

Elsbeth Hotz, baptized 1690.

Son:

Heinrich, baptized July 31, I 729 .

Parents:

Heinrich Steiner, baptized June I4, I705.

Angelica Jud, baptized May 2, I 706 .

Daughter:

Barbara, baptized February 27, 1742 .

Mother:

\section{From Esch}

Anna Hämmig, wife of Felix Fenner, deceased.

Children:

Hans Caspar, baptized May I4, I7I9.

Hans Heinrich, baptized July I 2, I 722 .

Felix, baptized November 3, 1725 .

Hans Jacob Brunner, son of Heinrich Brunner, baptized March 9, 1712, unmarried. 
Parents:

\section{From Uessikon}

Felix Zollinger, baptized July ıo, I698.

Elsbeth Reiff, of Uster, I697.

Children:

Anna, baptized July 20, 1723.

Hans Jacob, baptized November 7, 1728 .

Felix, baptized September 13, I733.

\section{From Binz}

Jacob Bantli, son of Rudolff Bantli, baptized March 13, 1718, unmarried.

Parents:

Bernhardt Wunderli, baptized August 21, I693.

Elisabeth Brunner, August 27, 1693.

Children:

Bernhardt, baptized November 29, 1730.

Magdalena, baptized January 28, I 733 .

Elsbeth, baptized February I3, 1735.

Heinrich, baptized December 15, 1737.

Father:

From Höll

Heinrich Trüb, baptized January 22, I 702.

Child:

Anna, baptized June 5, I74r.

Johannes Caspar Ammann, Pastor.

No. 54. From the Parish of Meylen the Following Persons have gONe to Carolina

June 25,1743

Born.

$\left.\begin{array}{l}\text { 17 I0, August 19, Andreas Haab. } \\ \text { I } 7 \text { I2, March 28, Dorothea Dolder. }\end{array}\right\}$ Husband and wife.

With their children:

1732, January 22, Regula.

I734, January Io, Barbara.

1735, July I7, Heinrich.

I 740, December 20, Hans Jacob.

This family paid the emigration tax.

\section{June 23,1743}

There left without permission from the honorable magistrate, or the knowledge of the pastor,

I678, March Io, Hans Jacob Widmer, widower.

With two daughters,

I 703, April 22, Anna. She took with her an illegitimate child by Conrad

Wunderli, named Maria, born 1736, November, 17.

I719, March 12, Elsbeth.

In July or August 1743 there left:

1716, September 20, Heinrich Widmer, shoemaker and his wife.

I 7 I2, September 4, Verena Kölliker, of Herrliberg.

They have no children.

Total from this parish, 12 persons.

April 6, I744.

Pastor TOBler, of Meylen. 
From the parish of Utikon no one has emigrated. (Written by another hand.) Attested: DeAn Usteri.

\section{No. 55. From the Parish of Mettmenstetten there Emi- grated either to Carolina or to Pennsylvania}

September 4, I738, from Rossau

Hans Buchmann, May 9, r7o2.

Regula Windisch, March 20, I707. To Carolina.

Hans Heinrich, July 28, 1737.

May 30, I739, from Untermettmenstetten

Heinrich Huber, April 14, 1715.

Anna Ruetsch, December I, I720. $\}$ To Carolina.

Verena Rüetsch, her unmarried sister, November 3, 17 I 5.

Anna Gallmann, daughter of Heini, deceased, of Heffertschweil, born June 5, I695.

To Pennsylvania:

May I, 1743, from Obermettmenstetten

Heinrich Ruetsch, March 8, 1708.

Verena Meier,

Barbara, January 26, 1738 .

Johannes Haug, from Untermettmenstetten, February I 4, I723.

Heiri Sutter, from Grosholtz, October I6, I 712.

Hans Jacob Rosell, of Hefertschweil, March 16, 1727.

Jacob Buchmann, of Dachlesen, September 14, I72I.

Unmarried Women:

Elsbeth Buchmann, daughter of Jogli, of Dachlesen, December 24, 1724.

Anna Ringer, daughter of Jacob, deceased, from Rossau, I 7 I 3.

\section{No. 56. NeffTENBACH}

Has lost the following families on account of Carolina.

I. Martin Gutknecht, of Hüniken, aged 39, who, with his wife, Margareth Bertschinger, aged 40 , and six children, Barbara, aged $1_{3}$, Elsbeth, aged I I, Heinrich, aged 9, Johannes and Andreas, twins aged 7, and Susann, aged 2, left, Anno 1736, with the intention of going to Carolina, but is said to be staying around Basel with them.

II. Barbara Müller, of Hüniken, an unmarried woman, aged 23, who went from here to Carolina in 1738 .

III. Jacob Keller, from the Oeden-Hoff, aged 43, who, with his wife, Susann Stephan, aged 36, and seven children, Andreas, aged 13, Rudolff, aged 12, Jacob, aged Io, Felix, aged 8, Heinrich, aged 7, Hans Jacob, aged 4, Hanss Rudolff, aged 3 , also left in $\mathbf{1 7 3 8}$, and no one has been able to find out anything about them since then, although they promised to write.

IV. Jacob Scherer, from der hintern Hub, aged 52, who, with his wife, Susann Bertschinger, aged 54, and three children, Barbara, aged 25, Hans, aged 23, and Adelheit, aged 20, also left in 1738 .

V. Also Gottfried Scherer, also from der hintern $\mathrm{Hub}$, aged 27 , and his wife, Elisabeth Huber, aged 30, who however, had no children, left in the same year.

VI. Finally Hans Ulrich Hagenbucher, of Hüniken, aged 4I, who, with his wife, Barbara Frauenfelder, of the same age, and three children, Elsbeth, aged I3, Margareth, aged Io, and Magdalena, aged 2, left here for Carolina June I 4, I 743, because he had been severely punished, at Kyburg, in the previous 6 
spring for blasphemous speeches and in addition to that had been obliged to hear from the pulpit a sermon expressly directed against him, and consequently was ashamed to live longer among the people here.

I received the circular on Good Friday morning and am sending it on before noon with many greetings to Pfungen.

Pfungen has not lost anyone to the new-found land except Rägula Eberhart, an unmarried wench, who died in Philadelphia in $174 \mathrm{I}$. Moreover, the mandate of $\mathrm{I} 7+\mathrm{I}$ cannot be read in public here because the heirs of pastor Schellenberg, deceased, have not left it in our hands.

IVith many greetings to the Honorable Board..........

No. 57. Solie Years ago there left the Parish of NiederHASSLEN FOR CAROLINA, not without official consent and permission, the following families from Nider-Hasslen:

Heinrich Volkhart who was baptized March 8, I69I.

Elsbeth Schütz, of Bachs, baptized October 6, I695.

Their children were:

Hanss, September 18,1717 .

Felix, November I4, I723.

Margreth, September I6, I725.

Heinrich, June 27, 1728.

Hans Heinrich, October 30, 1729.

Anna, April 5, I 739 .

Some years later the following family also left Niderhasslen, also not without the knowledge and official consent of our revered superiors. They had previously moved here from Ober-Embrach.

Hanss Conrad Müller, tailor. $\}$

Rägula Bosshart.

N.B. They took with them four daughters, the youngest still in the cradle, but their names have been forgotten since their departure.

Also Hanss Fröli, son of Ulrich Fröli, baptized November 6, 1718, left as a hired hand, Anno 1738.

Niderhasslen, April 3, 1744 .

Written in conformance with official orders by

Hanss Caspar Usteri, Pastor.

No. 58. From Oberglatt, according to the report of the pastor, the following persons have emigrated to Carolina or Pennsylvania:

\section{Anno 1739}

Two daughters of Hans Gassmann, deceased.

I. Catharina, born February 9, i 717.

2. Anna, born October 5, I721.

Anno $17+3$

I. Hans Därer, carpenter, born October 2, I692.

2. His wife, Dorothea Bertschi, born I694.

3. Hans Ulrich Brunner, son of the smith, born October 7, I713.

4. His wife, Barbel Kern, of Bulach, born March 12, 1712.

5. Chilion Maag, son of Chili Maag, deceased, born January 11 , 1722 .

6. Hans Bertschi, son of Felix, deceased, born November 24, I 720 .

7. Maria Marqualder, daughter of Melchior, born July 2, I 719.

8. Elssbeth Bertschi, daughter of Hans Bertschi, of Hofstetten, born January 24,1723 .

Attested: Johann CASPar Hegi, Pastor in Oberglatt. 


\section{No. 59. Oberwinterthur}

Greetings from the Source of Salvation. Most Revered, Most Learned Brethren, Beloved in the Lord:

Yesterday evening the inclosed communication concerning the emigration of our beloved parishioners reached me. You will read for yourselves what our honored and solicitous Superiors desire from us all, - and that without delay. I ask you therefore, to send this circular on as soon as possible, and to set to work upon it immediately, and to send me the document on a clean half sheet of paper so that each can send it to his neighbor and all can be sent to the parsonage at Winterthur, from whence I shall have them collected. I am sorry that this request has to be made in this busy Holy Week. I beg you again not to delay with it. With God's blessing and hearty salutations to the brethren,

Committing myself under God's grace to your love, I remain,

My honored and revered brethren's humble servant,

March 23, I744. SALomon ZIEGLer, Pastor in Oberwinterthur.

Winterthur, Wülflingen, Feldhem, Seuzach, Hetlingen, Hengart, Dorf,

Flach, Berg, Buch, Neftenbach, Pfungen, Dätlikon, Rorbas, Eubrach, Lufingen, Brütten, Töss, Winterthur, Called

OBERWINTERTHUR

IVINTERTHUR does not need the circular, for no one is thinking of emigrating from the country, and in such case the magistrate would have to speak with the citizens. We send this with many greetings to the good pastor at Wylfingen.

Wülflixgen. From the beginning I know of about 3 persons who have emigrated to Carolina, one single unmarried workman, Christof Bosshart from the Thal, born the 3I. June, I7I7, a shoe-maker's boy, who was persuaded by some people from Blumetshalden from the parish of Pfungen, who paid all his traveling expenses. He followed his mother and brother who had gone before him. I know of none who desire to travel at present. I received the circular at night of the 23., and am sending it with my enclosure the morning of the 24 th, with respectful greetings.

FELden. A year ago two persons left here with an official pass. Hans Ulrich Freyhofer, a weaver, thirty years of age; and Verena Freyhofer, his niece, twenty-four years of age, together with two relatives of theirs from the parish of Elg, at the request of a cousin who lived in Germantown in Pennsylvania, who has gained considerable means and has no children. I received letters from them two weeks ago saying that they had arrived safely after a difficult and dangerous trip. They advised no one to undertake this journey unless it was necessary, for on their ship and one other, over 200 Swiss people died because they could not endure the sea-sickness. They reported further, that if anyone is sick upon his arrival he is not permitted to leave the ship, so that many die in the harbor because of poor care. They also report that the present war has made the trip dangerous. Because of this report many have been kept back who otherwise were intending to follow them.

Received this circular, March 24, 9 in the morning, and sent it at 10 to the neighboring Seuzach.

SeuzAch. A year ago Jacob Müller, called Saxer, aged 40, with his wife Barbara Fritschi of Hettlingen, and three children, Heinrich, aged I3, Martha, aged II, Jacob, aged 7, left for Carolina against all my expostulations. Only a short time ago a young unmarried man of 35 years of age, who is working at Hüntwangen, Jacob Ackert, by name, has presented himself to me with a similar intention, and contrary to my advice, because of the good reports which have come back from there again recently, which induce many other people from his 
neighborhood and the country around it to leave for another land, has resolved to start thither in company with them, without heeding the fact that his own father, who is still alive, advises him against it and refuses his consent. The former and this latter (especially the former) are, to be sure, poor people who have persuaded themselves, among other things, that they cannot lose much either way etc., etc. I do not know whether I should add to these another man who was driven out of the country a year ago because of his debts, and who also has reported that he is going there, but who is still said to be staying near Basel, Sc. Christen Waaser, aged 40, with his wife Barbara Kleiner, and a boy, Jacob Waser, aged 5 .

Received this circular at II o'clock and sent it at I2, to the neighboring Reverend Dean, Pastor Hetling.

HetLingen. On the 3 oth of June the following persons left here for the West Indies, whether to the South or North they did not know themselves.

Franz Müller, aged 33.

Anna Herter, his wife, aged 37 .

Children:

Kungold, aged io years.

Anna, aged 6 years.

Franz, aged I year.

Margretha Kündig, Franz Müller's mother, born in Volken, aged 63 .

Jacob Müller Egliss, aged 38, unmarried. As far as I know these are the first persons, who have left here as colonists.

Henkert. As far as concerns the emigrants to Carolina: Before the sacred festival days are over, shall send a separate list of these. At this time I report merely, that last autumn a letter was received from such an emigrant out of my parish, dated London in England, in which he makes clear the misery of such emigrants, indicating that everything was true which the pastor had previously told him, moreover that they had been wretchedly misled by the false statements of other people, etc., and he threatened also, if at all possible, to return home with his wife and child.

People are talking now of another Carolina to which some wish to go, saying more of Schlesien, ${ }^{3}$ or Schlessingen as the peasants pronounce it, and allow themselves to dream very favorable things about such a land.

\section{No. 6o. From Oberwinterthur there went to Carolina with the Permission of the High Authorities}

Anna Tobler, widow, with two sons, Heinrich, born in I726, and Caspar, born in 1729.

Anno 1743, with permission, for Pennsylvania,

Jacob Sporer, a boy, born I719.

Hans Heinrich Rugstul and his wife with one son, Samuel, I9 years old.

Jacob Schupisser, bleacher, with a five year old son.

From Stadel, Heinrich Bryner, a youth, 26 years old.

From Rüttlingen, Ulrich Ehrensperger with his wife and five children: Clephe, born I721, Anna, I723, Johannes, I724, Lisabeth, I726, Ulrich, 1728.

Total 16 souls. God preserve them!

March 25, 1744 .

Pastor ZIEGLER in Oberwinterthur.

${ }^{3}$ Colonists were being solicited by Prussia for her province of Silesia, newly acquired from Austria. A.B.F. 


\section{No. 6i. List of those Persons who have left the Christian Parish of Detwyl for Pennsylvania}

\section{Anno I 743}

I. Jacob von Tobel, from Willikon, baptized June 9, I679. He was before this a churchwarden. Finally he gave over to his three sons his estate, and took from them besides a quantity of vines and grazing for a cow, for eight years annually 80 florins rental. He had a second wife, Elsbeth Frey from Uster. This man, without the knowledge of his people or of anyone else, left Sunday morning May I2, I743. His people estimated that he took with him about 65 florins.

2. Adjutant Hans Rudolf Egolff, baptized at Egg, in I678. He had with the knowledge of the authorities of Stäfa sold his fine little estate and after paying many debts and the emigration tax of 2I florins, 8 shillings, in opposition to the governor's and my kindly admonitions left here, with his second wife Elsbetha Pfister from Üetikon, baptized January I I, I692, and his legitimate son by his first wife, deceased, Hans Rudolff, baptized July 3I, I 729. Left on Monday, June 24, I743.

Total of all persons who went to Pennsylvania 4.

Attested by most obediently, Pastor Salonon Hirzel.

Otweil, April 6, I 744 .

\section{No. 62. OssLingen}

Highly Revered, Learned and Honorable Mr. Dean:

In reply to the command and mandate which has come from my gracious master and superior, in respect to those who have gone into the so-called newfound-land, I notify you most dutifully and properly that at the present date there is no one in my parish who wishes to commit such folly. A year ago Alexander Haussrad with his wife and their children wanted to leave, but he returned poor as a beggar, gave over his wife and three children as a burden to the parish, while he treacherously and secretly went into military service in Savoy, which is all that has been reported in regard to this questionable affair. I have the honor to subscribe myself, with the highest conceivable respect, the Dean's life-long most humble servant,

Osslingen, April 3, I744.

A. Burkhard.

No. 63. List of those Persons who left the Parish OttenBaCh to go to Pennsylvania

\section{From Ottenbach}

Hans Ulrich Hegetschweiler, Heinrich's son.

Hans Jacob Sydler, Marx's son.

Anna Hegetschweiler, deceased Heinrich's daughter.

Caspar Frey, Felix's son.

\section{From Wolsen}

From Ober-Lunneren

Heinrich, and Hans Bär, brothers, Heinrich's sons.

From Under-Lunneren

Johannes Gut, deceased Heinrich's son. 
No. 64. Description of the Three Families that left the Parish Ottelfingen to go to Carolina

Anno 1738 in August there left the following families:

Parents:

Born: 1697, Heinrich Weltj, from Poplizen.

“ I693, Barbara, from Reütj.

Children:

“ 1726, Rudolff.

“ 1727 , Hans.

“ I729, Anna.

“ 1732, Clein-Anna.

Anno 1743 , May $3 \mathrm{~d}$, there left the following families:

Parents:

Born: I7II, Hans Meyer.

“ I7I5, Elsbeth Bopp.

“ I735, Elsbeth.

Children:

“ I736, Barbara.

Anno I 743 in May there left the following families:

Parents:

Born: I7I3, Caspar Meyer.

" I7I6, Anna from Reütj.

“ I 740, Caspar.

Children:

“ I 742 , Anna.

No. 65. From the Parish Pfäffikon in the Suminer of 1733 THE Following Left FOR THE NEw WORLD

Heinrich Ernj, from Pfäffikon, baptized April 10, I707, and Susanna Brunner, his wife, together with a child: Babelj, aged 2 years.

Anno 1734 there also went there:

A. Magdalena Mäntzin, the deceased Hans Hermetschweiler's wife, with the following children:

Annelj, baptized, January 7, I7 I4.

A. Magdalena, September 29, I 7 I5.

Babelj, November 21, 1723 .

Margreth, October 2, I725.

Regelj, October 28, 1727 .

Heinrich, June 3, I73I.

April 25, 1744 .

Attested, John Feer, Pastor.

No. 66. List of all Persons, who since 1734 went out of the Parish Raffz, thus Leaving their Home and FatherLAND:

I738, September. According to the report received, the following persons left, with the purpose of going to Carolina:

Hans Ulrich Angst, son of Andersen, and

Barbara Sigerist, his wife. These have taken with them

Johannes Sigerist, a ten-year old boy, the brother of the wife.

Hans Jacob Graaf, shoe-maker, and

Anna Schweizer, his wife. These left with 5 children. 
Barbara Meyer, Jacob Meyer's legitimate daughter, born August 21, I707.

Total i I persons.

N.B. These left my parish of Rafz, and I know no more to say about them, except that up to the present I have not been able to find out what destination they reached.

I741, April 19. Franz Neuchum, the joiner, born 1694, left the country with his oldest daughter.

Verena, his daughter, born January 7,1725 .

N.B. He has left behind his wife with threa small children, because he was angry that the meagre means of his oldest daughter, whom he was taking along, were not permitted to pass through. I do not know of what those means consisted. This man, so a report was received concerning him, died a few days after his arrival in the capital city of Philadelphia. The remaining wife and children are being supported by alms.

Total 2 persons.

1743. May i6. The following left Rafz with the intention of going to Pennsylvania:

Hans Ulrich Baggenstosz, mason, born I 700.

Susanna Baur, his wife, born 1699 .

Children:

Verena, 1725 .

Hans Ulrich, 1726 .

Johannes, I 734 .

Susanna, 1737 .

Heinrich, 1738 .

Hans Jacob, I74I.

In addition to this there left with this mason:

Franz Graaf, the deceased mason's son, born 1733. This boy was the abovenamed Baggenstoss's deceased sister's son.

Catharina Neüchum, I 7I8. Franz Neüchum the shoe-maker's daughters from Verena Neüchum, I720. $\}$ Sulgen.

Johannes Reutschman, deceased Conrad's son from Rafz, I716.

Total leaving in I743: I2 persons.

N.B. Of these nothing has been heard up to date.

1744, March 3I. There left from Rafz, wishing to go to Pennsylvania the following:

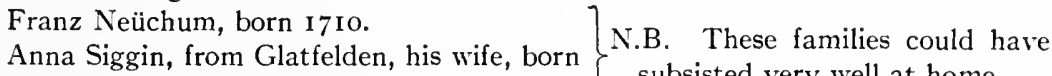
1705.

Children:

Verena, 1734 .

Heinrich, I 735 .

Verena Neüchum, Hans Graaf's, the bailiff's widow, born 1704 .

N.B. This poor widow with her children has very little money with her, relies upon, besides God, her brother Franz Neüchum and her brother-in-law, John Neüchum, who have promised her all needed assistance. Did not give heed to any warnings.

Children:

Barbara, I 729 .

Franz, 1734.

Johannes, 1737 .

Hans Jacob, I 740.

Hans Ulich, 1742 .

Johannes Neüchum, wagon-maker, 1697.

Susanna Neüchum, his wife, 1698.

N.B. This family might have found an honest living at home. 
Children:

Verena, 1732.

Heinrich, 1735

Johannes, 1737 .

Susanna Schweizer, deceased Hans Baggenstoss's widow, 1700.

N.B. Also this widow might have had a modest subsistence.

Children:

Hans Jacob, I 73I.

Johannes, 1736.

Hans Ulrich Sigerist, called Melchers, I698.

Elisabeth Baur, his wife, 1706.

Barbara, I734.

N.B. The needed subsistence was not lacking also in the case of this family.

Furthermore:

Hans Graaf Lehmens, I697, weaver.

N.B. This poor man, who has been able to take very little money along, goes away with his large family, forced by necessity.

Elsbeth Frey, his wife, I698.

Children:

Elsbeth, I 726 .

Barbara, 1728.

Heinrich, 1730 .

Hans Ulrich, I 733.

Hans Jacob, 1737 .

Dorothea, 1741 .

Hans Sigerist, son of Hans Jö.lis, born 1705 .

Anna Wildberger, from Neükirch, his wife, 1709.

N.B. This man has had respectable means, but has been a poor manager, and as a result could not for long have kept up. Therefore he was also ill-provided at his departure.

Children:

Hans Jacob, I73I.

Franz, 1738 .

Anna, I 740 .

Susanna, 1742.

Grown up-unmarried children

Heinrich Meyer, tailor, Heinrich Mejer's son, I 724.

Heinrich Baur, carpenter, the shoe-maker Jacob Baur's son, I 724 .

Hans Conrad Hänseler, deceased Kestl's son, I 722.

Unmarried daughters

Verena Graaf, deceased Hans Jacob's daughter, I 7 I6.

Catharina Neüchum, deceased Salomon Neüchum's daughter, 1723.

Total of all of those who from 1738 up to the present date have left Rafz66 persons.

The truth of the above attested April I, I 744, by John Heinrich Holzhalb, Pastor at Rafz.

N.B. These last named grown-up boys and daughters, have, to be sure, left with the above, but not exactly with the intention to settle in Pennsylvania, but to travel, in part supporting themselves by their trades, in order to gain experience, or in part being people of little means, to seek their fortunes elsewhere, if possible, and they entertain the hope, that if they return as free men and with good testimonials of their behavior, they may return without prejudice to their landrights. 


\section{No. 67. Regensperg. From this parish there have gone to Carolina, etc.}

Johannes Bachofen, glazier, aged 22 years.

His pregnant wife was left behind.

The departure took place September 18,1734 . On the way he changed his mind and entered the French military service, in which he died, in the spring, 1735 .

Felix Huber, glazier, aged 37 years.

Anna Müller, his wife, aged 39 .

Children:

Catharina, aged 5 .

The departure took place September 8, 1738. Nothing has been heard about these since.

Jacob Schwenk, shoemaker, aged 46.

Catharina Belz, his wife, aged 42.

Children:

Anna, aged 5.

Elisabetha, aged 4.

Anna-Marja, aged 2.

With them there travelled also Esther Schwenk, the daughter of Johannes Schwenk, the tailor, aged i 7 years. The departure occuired April 4, 1741. Concerning these, their arrival in London and prospective sailing for Pennsylvania, but beyond this nothing has been heard, except that recently, without good foundation it was reported that they had arrived in Pennsylvania, and that one of the children had died.

Total of those that left-io.

Attested by Јон. Јасов WoLfF, Pastor in Regensperg.

March 31, I744.

\section{No. 68. Extract from Pastor and Chamberlain Vogler's Communication from Richtersschueil}

As far as concerns those who left for West India, there left here for Pennsylvania about thirty years ago several by the name of Höhn and Wisz, who wrote once or twice without much exaltation, and part of them have died.

Rodolph Bachman, son of Rodolf, is said to have gone to Carolina about five years ago, but we know nothing of him.

In the week following Whitsuntide there also went thither two by the name of Huber, and one Tanner, with wife and children. The latter has six children, five sons and one daughter, among them an infant three weeks old, and the oldest twelve years.

Several times the magistrate and myself spoke to him earnestly, whereupon he replied: He could not ward off bankruptcy, that he wanted to sell his possessions and if anything remained, to stay at home, which, however, he did not keep, and said: "He could now not do otherwise."

The carpenter Huber has taken eight children with him together with his wife, among them seven sons, the oldest 14 , the youngest $1 / 2$ year old. His brother Jacob Huber has left with his wife and three children, did not ask leave, his boy is Io, one daughter 4 , the other I year old. They are people who could no longer sustain themselves with their work, and nothing could be done with 
them, whatever you might say, their reply always remained: They had to work here day and night and even then could not get their daily bread, and were therefore forced to seek it elsewhere.

Still another Bachman is said to have gone to Pennsylvania before the war, and to have died there.

Richtenschweil, May I5, I744. Attested, Joh. Felix Vogler, Pastor.

\section{No. 69. Rorbass}

From this parish there went to Carolina in the year 1738 , the following parties:

Hans Conradt Rietiker, mower, aged 49.

Verena Hiltibrand, his wife, aged 46.

And their children:

Hans Jacob, aged $\mathbf{r} 6$.

Jacobli, aged 10 .

Caspar, aged 6.

The same year:

Jacob Rietiker, tailor, aged 47.

Barbel Dünki, aged 4I.

And their little daughter:

Margareth, aged 9.

The same year:

Heinrich Rietiker, sexton, aged 38.

Rägula Landert, aged 36.

And their children:

Heinrich, aged 7.

Catharina, aged 3 .

Barbara, aged $1 / 2$.

Furthermore there left anno 1738 at the end of August, from Rorbasz to Carolina:

Conradt Fritschi, weaver from Freyenstein, aged 38.

Rägel Hiltibrand, his wife, aged 33.

And their children:

Heinrich, aged 9.

Babeli, aged 7 .

Heirechli, aged 5 .

Elsbeethli, aged 2 .

Rodolf, aged 3 months.

The same year:

Conradt Dünki, called Alpen-Baur, aged 6o. Widower.

And his children:

Heinrich, aged 25.

Anna, aged 22.

Total of all who in 1738 left for Carolina: 23 .

Furthermore in the spring 1743 , from Rorbasz for Carolina, the following parties left:

Jacob Dünki, the above alpine farmer's son, aged 36 .

Anna Dandert, his wife, aged 34.

And their children:

Heinrich, aged 5 .

Jacobli, aged 4 .

Cathari, aged 2.

The same year:

Hans Jacob Schurter, son of Kräuszli Hans, unmarried, aged 25. 
The same year:

Heinrich Fritschi, son of the old castle-farmer from Teüffen, aged 4I.

Anna Brändli, his wife, aged 39.

And their children:

Clephee Babli, aged I4.

Vreeneli, aged 12.

Anneli, aged 7 .

The total of all those persons gone away in $1743-\mathrm{I}$.

Grand total of all who left with my knowledge but against my will, and against my earnest protests: 34 . Of all of those not a word has been heard since their departure. The Gracious Dean need not fear an exodus this time.

Rorbass, March 27, 1744 .

Pastor WOLFF.

\section{No. 7o. RÜMLANG}

From this parish there went to Carolina in the year 1734 :

Rudolff Weidmann, a tailor, born 1699.

Anna Maria Wäber, from Zurich, his wife, born I7II.

Children:

Judith, born 1732 .

This was a poor family, the husband did not understand his trade, and there was the greatest anxiety that they might become a burden to the authorities.

Anno 1735

These wanted to go to Carolina:

Heinrich Meyer, a mason, born 1703 .

Elisabetha Schmid, his wife, born 1700 .

Children:

Heinrich, born 1729 .

Hans Heinrich, born $173 \mathrm{I}$.

This household, however, got only as far as Kreuzach in the Margravate of Baden, where they settled, and thank God live happily, and in the year $173^{8}$ were increased with a son Tobias. The reason why they left their fatherland was hard times and debts.

Anno 1736

Left for the new country:

Jacob Gering, born 1700 .

Anna Cappeler, his wife, born 1698.

Children:

Catharina, born 1725 .

Heinrich, born $173 \mathrm{I}$.

This family was also very poor and the father was almost blind.

They took with them their oldest son Johannes, born 1725 . The two younger sons Hans Conrad, born 1727 , and Heinrich, born 1729 , they left at home. But after this man, like a real good-for-nothing, had spent all his money, that he had intended for the trip to Carolina, consisting of about $\mathbf{1 5 0}$ florins, and got to Frankfurt, he went to Berlin, according to reliable reports, and lives now upon a Royal Prussian colony. The son Conrad left not before 1743 with a party for Carolina. The younger, good-for-nothing in body and soul, is bound in service for twenty years in the governmental hospital.

\section{Anno 1743}

There left for Carolina, with permission of the most revered governors: Caspar Hinnen, born 1709.

Elsbeth Widmer, his wife, born 1707. 
Children :

Caspar, born 1736.

Anna Barbara, born 1738 .

With these there also left:

Heinrich Hinnen, the unmarried brother of the above, born I7I 4 .

Rudolff Schmid, the deceased Fridlis' son, born 1722.

Also the above-mentioned Conrad Haszler.

There left also, without anyone's knowledge:

Caspar IVäber, a table-maker by trade, born i 705 .

Margareth Gering, his wife, born 1705 .

Son: Johannes, born 1734 .

This family was compelled to leave on account of poverty into which they got through their own indolence and dissoluteness. They are settled, it is said, on Würtemberg lands.

Attested by most humbly Havs Heinrich Volleniveider, Pastor. April 4, I744.

\section{No. 71. There left for Carolina out of the Parish}

\section{RUSSICON}

Hansz Ulrich Ringger.

Margreth Boszhardt, his wife.

Children:

Jacob, baptized September 8, 1737 .

Hans Jaco, baptized, September 27, 1739 .

Attested, as per circular: Fel. Nüsch, Dec.

\section{No. 72. Schlieren. (See Plates 3-7)}

Most Honorable, Learned and Most Revered Dean:

Because I have the honor, as a humble member of the chapter of Zürich, to be remembered with the circular, but as far as mandates and decrees are concerned cannot follow them, being under the jurisdiction of the County of Baden,so that many times, though being so near the city, and so near to me the authoritative mandates are read, I am at a loss what to do in regard to this or that command; whereas a list of those of the parish in war service, as also of those who have gone to North America, who have gone either with permission, or at least with passes from the governor of Baden, in opposition to my public and private repeated warnings and arguments well founded, is asked for by the circular, I have thought it to be of some service to prepare a list of those who since ten years have gone to Carolina and Pennsylvania as into another land, "cut off from the righteous," ${ }^{4}$ with wife and children.

I. Anno I 735, Conrad Rütschi, aged 37, with his wife Barbara Lips, aged 38, and two children, the oldest II years, the other 9 years old. Concerning this family the most Rev. Dean has read the letter that has come to me.

II. April 7, I 736, there left the sometime commissioner Caspar Müller, aged 5o, together with his wife, Margareth Zimmerli, born in Arburg, with three young children. A son and daughter remained behind.

III. May I 5, I 743, there left here amid pitiable lamentations of several mothers, accompanied by a large crowd of people as far as Fährli, the following families:

${ }^{4}$ This quotation appears in Hebrew in the original manuscript, photographs of which are herein reproduced (Plates $3-7$ ). 


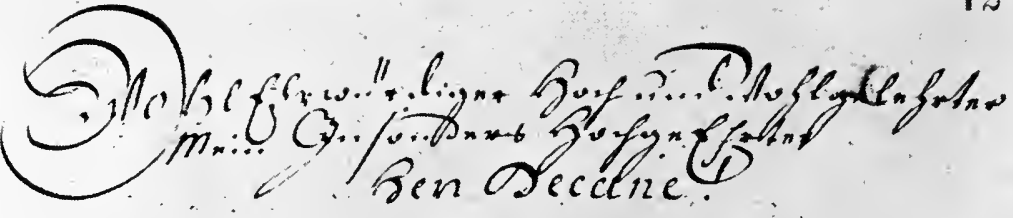

$\left(\operatorname{lin}_{n}\right)$

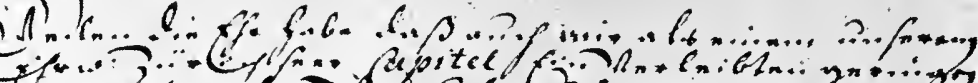

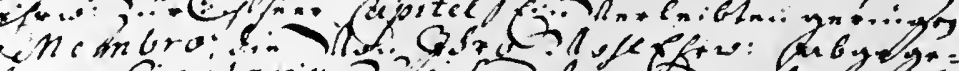

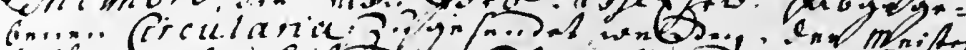

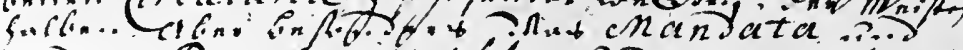

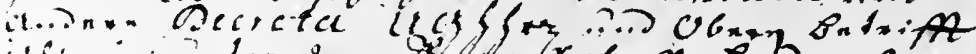

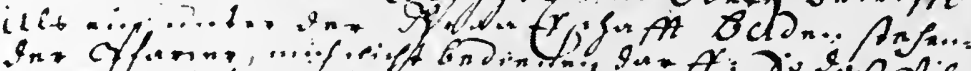

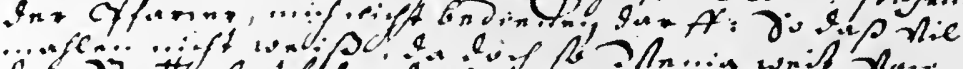

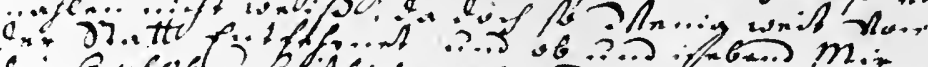

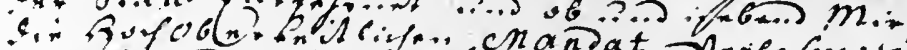

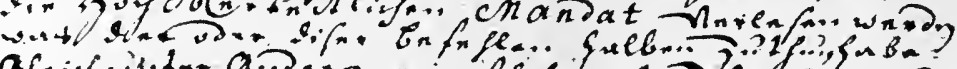

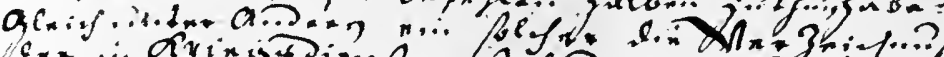

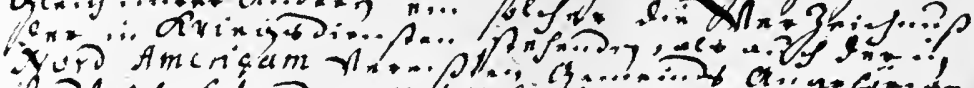

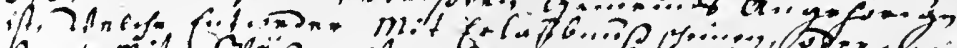

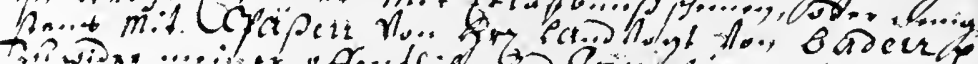

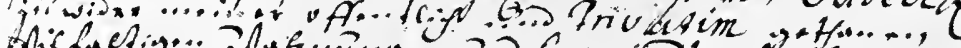

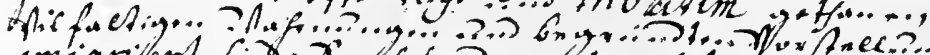

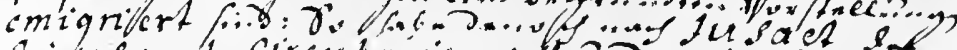

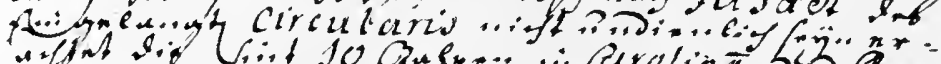

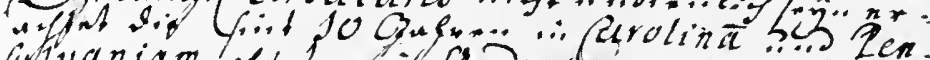

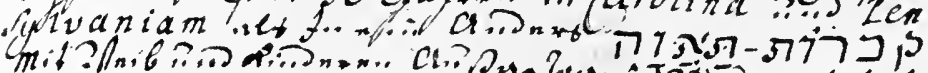
mit? भis

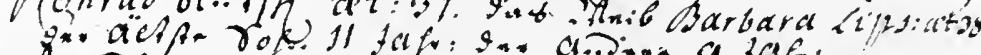

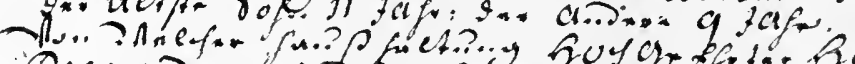

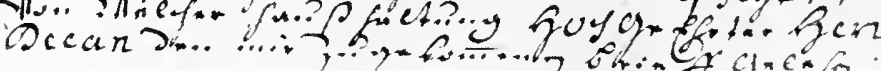





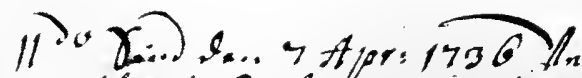

misani G o m,?

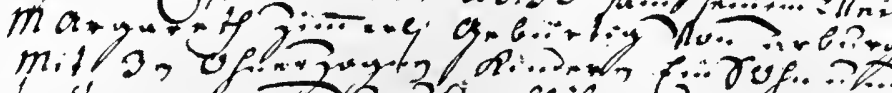

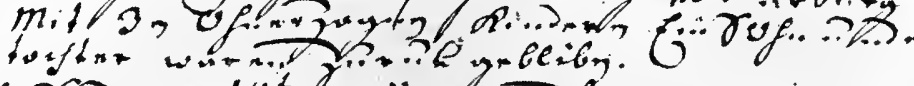

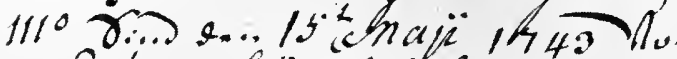

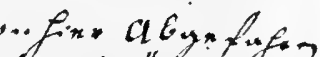

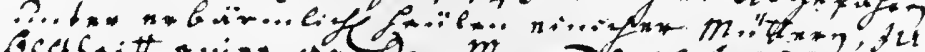

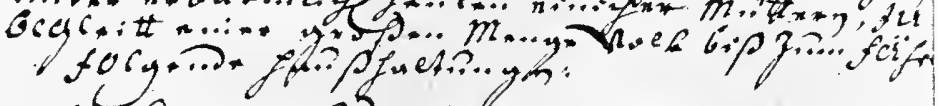

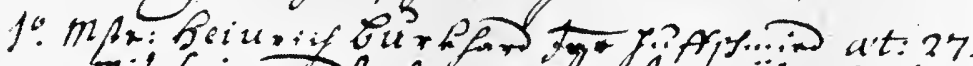

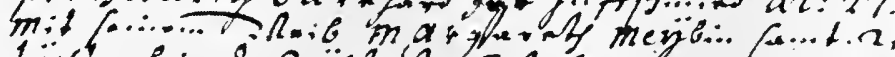
$10 \mathrm{~m}$......

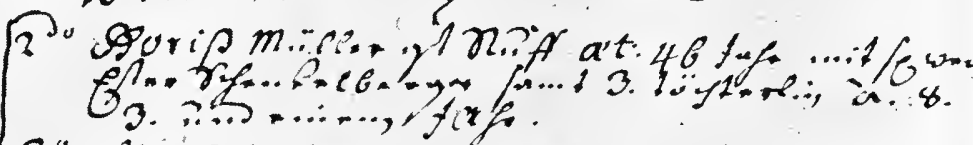

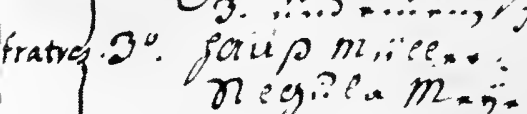

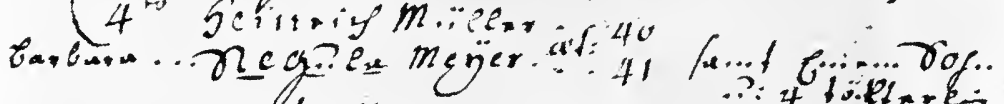
Seu $y$ fuli 1743 r...) Mnnnist mit.

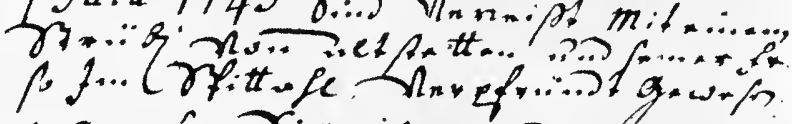

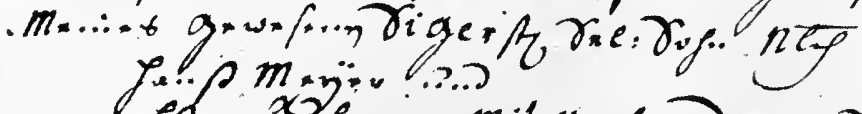

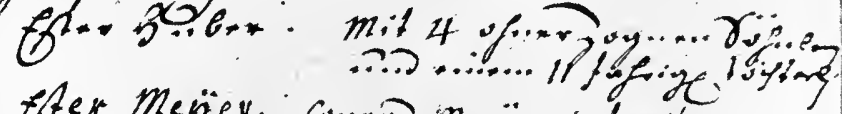

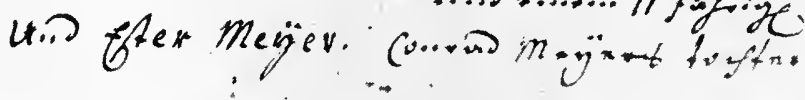





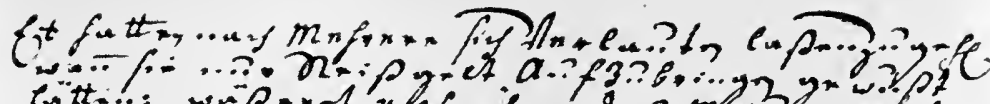

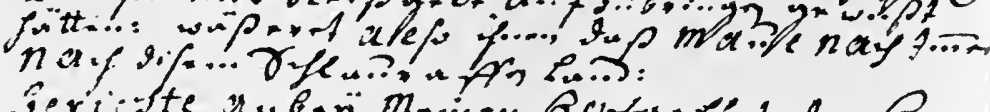

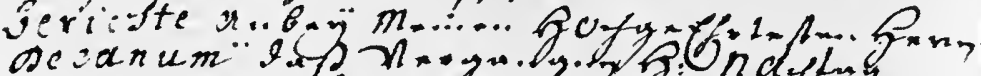

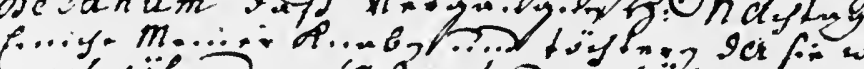
…g y.

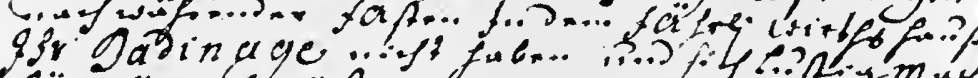

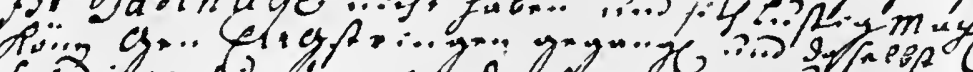

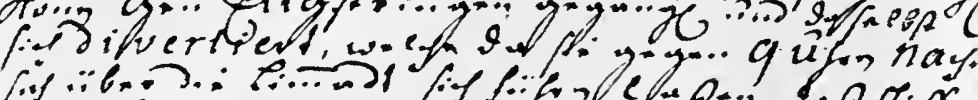
fis $\because b_{n}$.

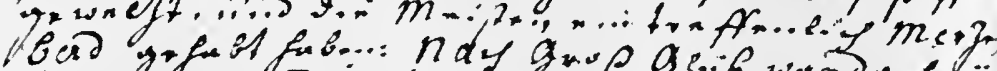

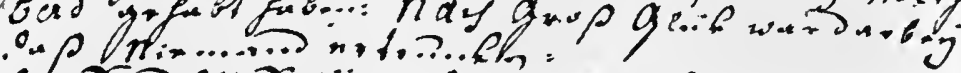

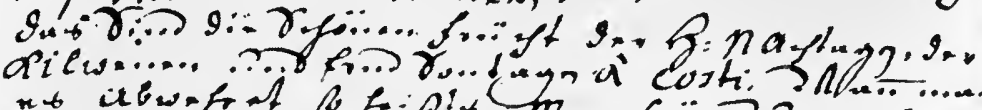

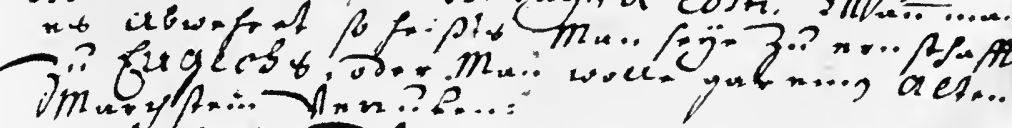

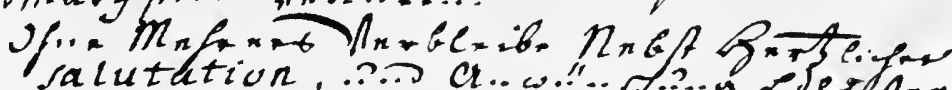

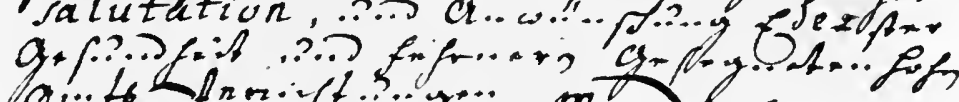

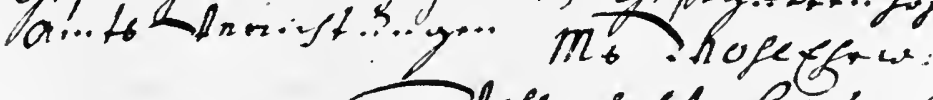

Orgeieners.

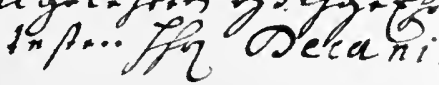

ri 3 hthorilis 1744 .

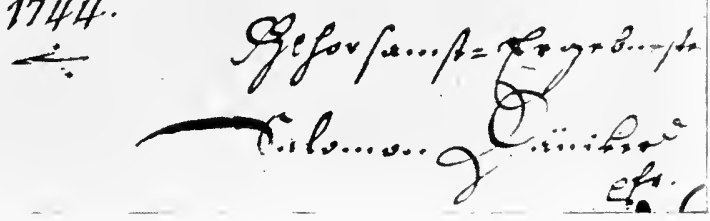

PAGE 3 OF List No. 72 

Plate 6

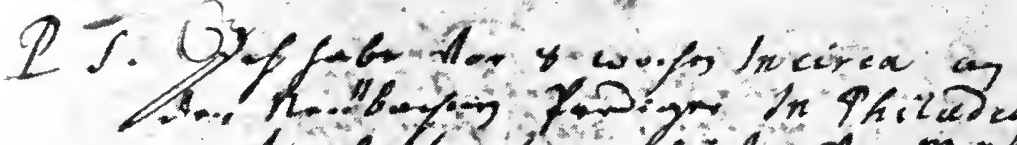

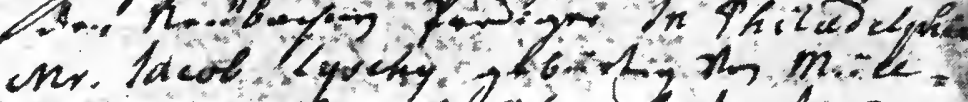

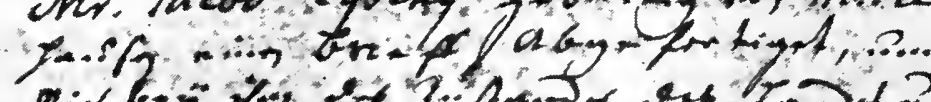

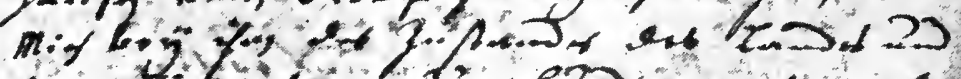

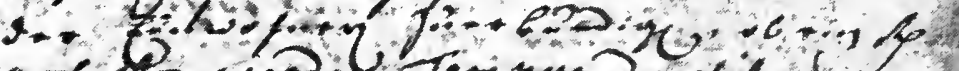

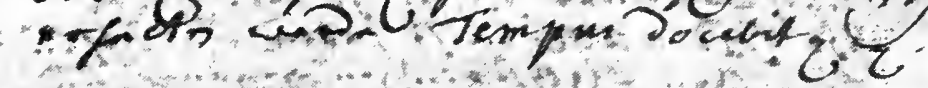

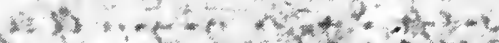

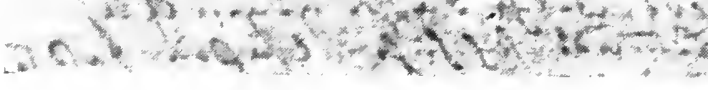

Page + OF List No. 72 

\#chlehwildiger, hoch und wohlgelehrter mein Jnsonders hochgeehrter Eerr Decane.

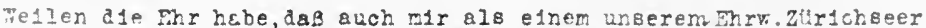

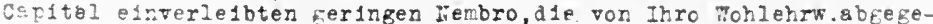
beren c1rouleria zusesendet werden, der meisten halben aber besorders has :andata und andere Decreta UaHiren und oberer betrifft, els efa unter der Grasfachafft Baden stehender Pfarrer mioh nicht bedienen darff: So das v1lmahlen nioht we1e, de doch so wenig weft von der ftatt extfehmet und ob und nebend mit die hoohoberke1tilchen wandat verlesen rerden, was dér oder diser befehlen halben zu thun habe. 6] edch unter anderen eln sooloher de Verzelchnus der in Xrlegalensen stehenden, als auoh der in Ford Amer1cam Verre13ten Gemeinds An-

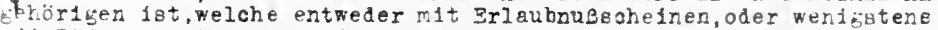
mit fusen von Herrer Lendvogt von Baden, zuwlder relner offentilch ano Cutratim gethanen vilfaltigen Wahraugen uad begrindten voratellungen emigriert sind: So hab denoch nach Jrhalt des elnpelingten c1rouleris nicht undienlioh sem erachtet, die Eint lo Jahren in $28-$ rolinwind Fensylianiam als in ein anders T. und rinderen Aucezogne zu denominieren.

I ${ }^{\circ}$. Ist 10.1735 verre $13 t$ to

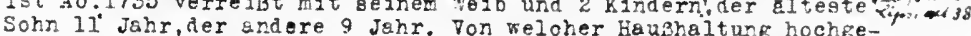
chrter Herr Decan den mir aukekommenen Brieff gelesen.

IIU. Sfnd den 7.Apr.1736 verrelat gexesner oomplbarl Caspar Muler, eet.50, samt Beinem $\pi \in$ bb :iergareth .1mmerly, geburt1g von Arburs. mit 3 ohnerzognen $\mathrm{k} 1 \mathrm{nd} \in \mathrm{rn}$, ein Sohn und in Toohter waren zurlokcebliben.

III Sind den 15 ten vaj1 i743 von ner abgefabren nuter erbarmlichen hellen einlcher wittern, in begleft ciner gropen wenee voli bis 2.um Fthrlj folgerde Haushaitungen:

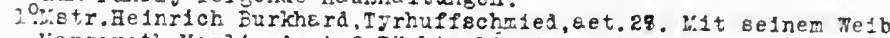
Hargareth "̈eylin, damt 2 Töohterlín,de alteste 2 Jahr und das anderc 10 ïonat.

(20.70r13 ziller gt.Ruff, get.46 Jahr, m1t ge1nem refo

30 ster Scherixiherger, sant 3 Töchterlin, \& 8,3 und einem Jahr.

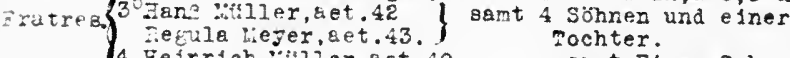

4. Feirr1ch Willer, get.40. Gant Einer Sohn und

Barbara Revila aejer,get.41. A Töchterin.

Ver 7.0 ints

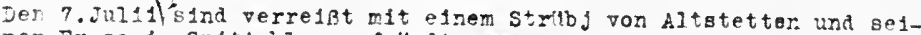
ner Fr.so in spittahl verpfrindt cewesen.

:e1res geweseren s1Eersten sel.Sohn mlch.

Hon. Heyer und Hit 4 ohrerzognen Sohnle1n und einem II

ister Fuber. Juhrigen iöchterlj.

"ua acter zeyer.conrad :eyers pochter.

So hatten nech zehrere sich verleuten lafen, zu gehen, wann sie nur

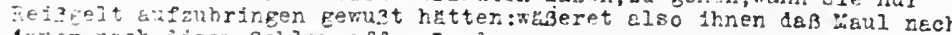
L" er rech aiser Schauraffen Land:

Efrohte Erhey reiren Foch geehrtesten Herren. Decanum, dap vereanene

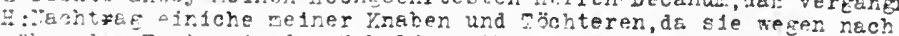
wehronder pasten in der puhrls i"irthsheu? Ihr Eadinace nicht huben urd stch lust1e machen köner gen snestringen gegngen urd dasel hst

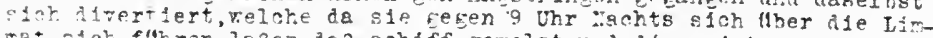

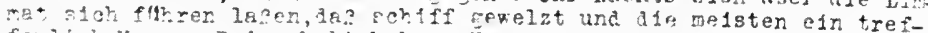

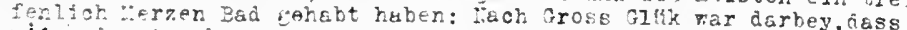
rierand extrunier.

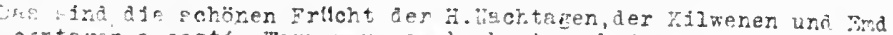
ourtegen a cost1. Tarn run es aborret, co hejats. Man seje zu enret

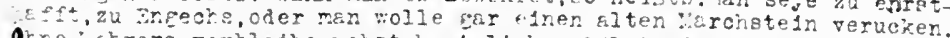

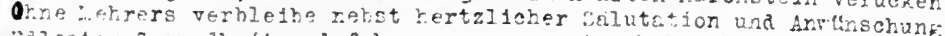

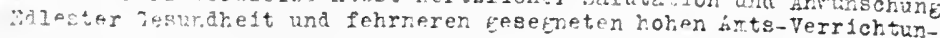
erer.

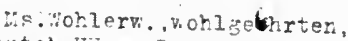

Wocheehrtasto Heren jecan Grhorsimet nrebenster

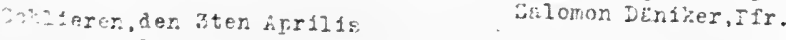
$7 \because \dot{q} \dot{4}$

Reproduction of the Transcript froN List No. 72 




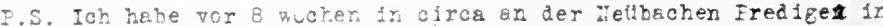

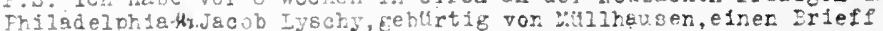

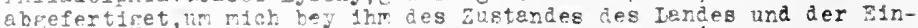
wohnern $z$ erkindigen, of im. Intwrit] erhalten verde. tempus doceh1t.

I70.73.

Terzelchnus dertentgen, welche aub der ffarr Scheflistorf sẹt 1734 peggere1get, willen in ireriea. Bt- Funs :erkj Jopuliert 11. Febr.168 monet ron Schefflistorf. Ifsabeth Weiffeler den 5.Xor1s 16.7br. 207 .

\begin{tabular}{|c|c|}
\hline & $\begin{array}{l}\text { Zinder: } \\
\text { Barbara } \\
\text { Eeregethe }\end{array}$ \\
\hline Ihr erstgebohrner sohn. & $\begin{array}{l}\text { Heinr1ch :Her } \\
\text { Verera puhe }\end{array}$ \\
\hline & $\begin{array}{l}\quad \text { Kinder: } \\
\text { iacob } \\
\text { Eudolfe } \\
\text { snra } \\
\text { Regula } \\
\text { Verena }\end{array}$ \\
\hline
\end{tabular}

10. Febr.1715. 1702 .

Ton oberwentingen.

Von sohlyxiken.

1741,18, Apr11 Von cberkentrigen.

$1743,21 . \Delta p r 11$

buch von Oberwenfrgen.

Ab aen XIupf
Suganna, Bars Surbera gel.Tochter.

Heinrich, Hans Eeinfloh, Rummen sel.sohn.

$17.88 j 1716$.

Caspar Surber / copuliert auf die Barbure Lerky labre1e 14.jerte 1741 .

Heng, Jacob Juttwefler-a Sohr. Hens, Fans Heyers Sohn.

$11.7 \mathrm{br} .2718$ Lartis 171 7.Anr11. 1715 29. $\mathrm{Ju} 1.2731$. $1.8 b=.1733$.

7.AuE.1735.

1. Jan. 1738 .

30. Ju1.2713. $16.8 \mathrm{br} .1721$.

Heinrlch Surber, Jucohe Sohn. Hane, Jacob Jöbelis. Sohr.

Catrarina, Ehegamer Duttwe1lers sel.Tochter.

17.40 s 1723 $22.9 \mathrm{br} .172 \mathrm{z}$. 28. Ju1.1726.

Jacob zöbelf!Hans zöbelis sel. Hans i sohr.

23. Febs.1716 6.8 br1e $172 \dot{\varepsilon}$.

Summa:22.

Bescheint Hans Jacob irrodj, den E6ten bertz 1744.

ITo.74.

Verzefchnus derjennigen Persohnen, so aub der Gemeind Schwerzenbooh in Carolinam abgereiset a1nd.

1. Jecoh Diethrich, Dilkelm Diethriohs Sohn, gebohren den 19. Juil 1716. Verrefoete im Augusto 1738.

2. Ferner Hana UIrfoh Bletrann, geh.der 22 . La1j 1703 urd gein Fherefb

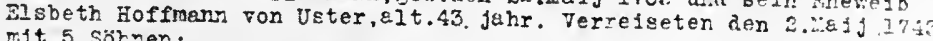
mit 5 Sörnen:

1. Christophel, cetauft den 2E.Apr.1725.

2. Rudolff. 5. Xuim. 1732 .

3. Chr1stoffel, - 25 . Teinm. 1739.

4. Jicob. den 4 tornune 1720

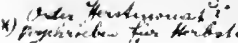

Hena den 18 . Harstm.1740

Reprodlction from the Trinscripts of Lists No. 73,74 

Plate 9

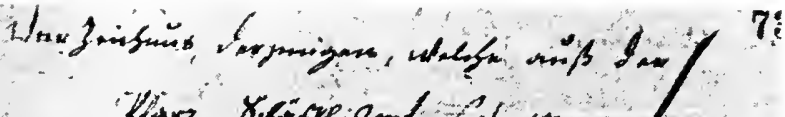

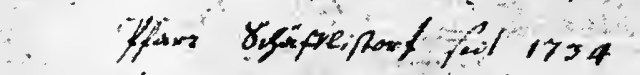

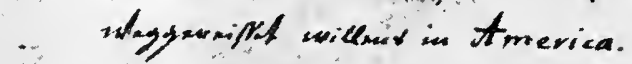

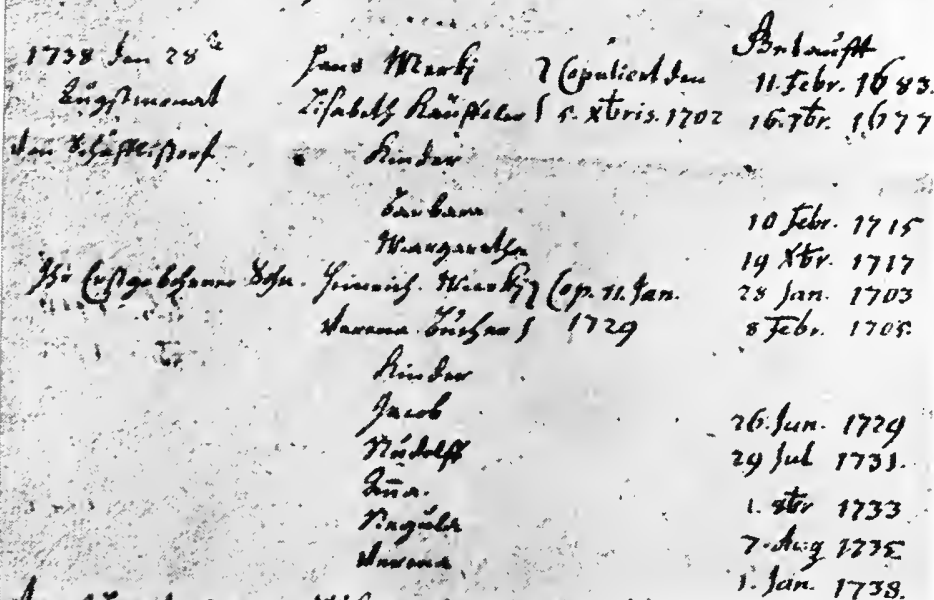

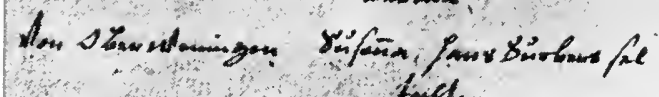
trighter

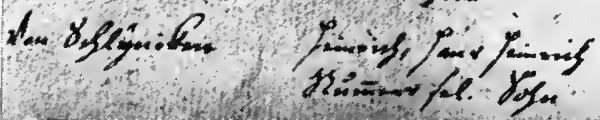

$30.915=1213$

17. Mas: 1716

1741. is 24 mandprit.

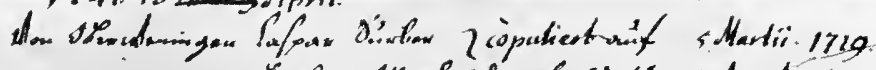

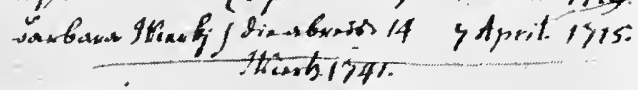

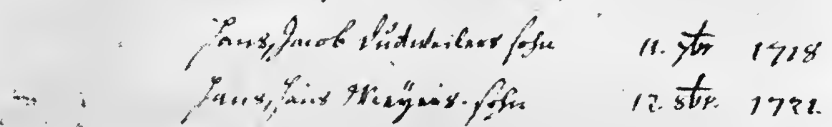
1743. 21. April.

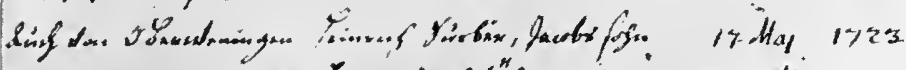

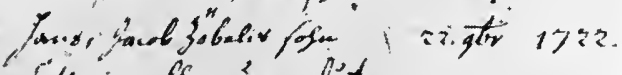

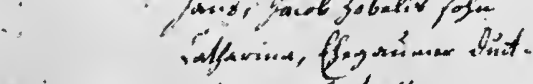

It dasen Risigf wherears, le tagher.

28 f4. 1726

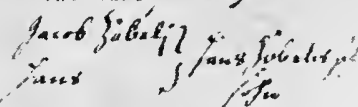

23 स6r. 1416

6. stris 1922.

Sหind ? ?2.

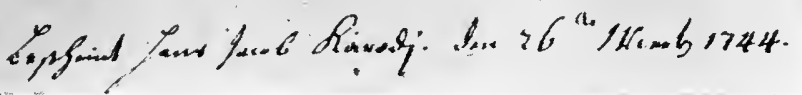

Reproduction of the Original List No. 73, "Parish Schäfflistorf,

SINCE I734' 
I. Master Heinrich Burkhard, blacksmith, aged 27, and his wife Margareth Meylin, and two daughters, the oldest two years and the other Io months.

2. Goriss Müller, called Ruff, aged 46, with his wife Ester Schenkelberger, and three daughters, at 8,3 and I years.

3. Hans Müller, aged 42 .

Regula Müller, aged 43 .

$\{$ With 4 sons and I daughter.

4. Heinrich Müller, aged 40.

Barbara Regula Meyer, aged $4 \mathbf{I}$. $\}$ With I son and 4 daughters.

July 7, I7 73 , there left with a certain Strübj from Altstetten and his wife, who had been a serf at the hospital, my deceased sexton's son, Hansz Meye: and Ester Huber with four infant sons, and a daughter II years old. And Ester Mever, Conrad Mever's daughter.

Several others had spoken of going, if they had only had the money to travel with, their mouths evidently water for the land of indolence and plenty. (Schlaraffenland.)

I beg also to report to the Most Rev. Dean that several of my young men and women, since they could not during Lent have their.sport and enjoy themselves in the inn at Fährli, went to Engstringen and diverted themselves there, and about 9 o'clock at night since they had to be ferried across the river Limmat, rocked the boat and most of them had an excellent March bath; it was a great piece of good fortune that no one was drowned.

These are the beautiful fruits of the Holy Week, of church and Sunday festivals. If you try to prevent it, they say that you are too serious, too narrow, or that you wish to remove ancient boundary-stones.

IVithout more to say, I remain with heartfelt salutation and wishes for the best of health and blessed execution of your high offices,

Your etc. etc., Most obedient,

Schlieren, April 3, 1744 .

Salonon Däniker, Pastor.

P.S. About eight weeks ago I completed a letter to Mr. Jacob Lyschy, ${ }^{5}$ preacher in Philadelphia, born in Müllhaüsen, in order to inquire of him as to the condition of the land and its inhabitants. Whether an answer will be received, time will tell.

\section{No. 73. List of those Who left the Parish Schäfflistorf Since i734, With the Intention of Goixg to America (SeE Plates 8, 9)}

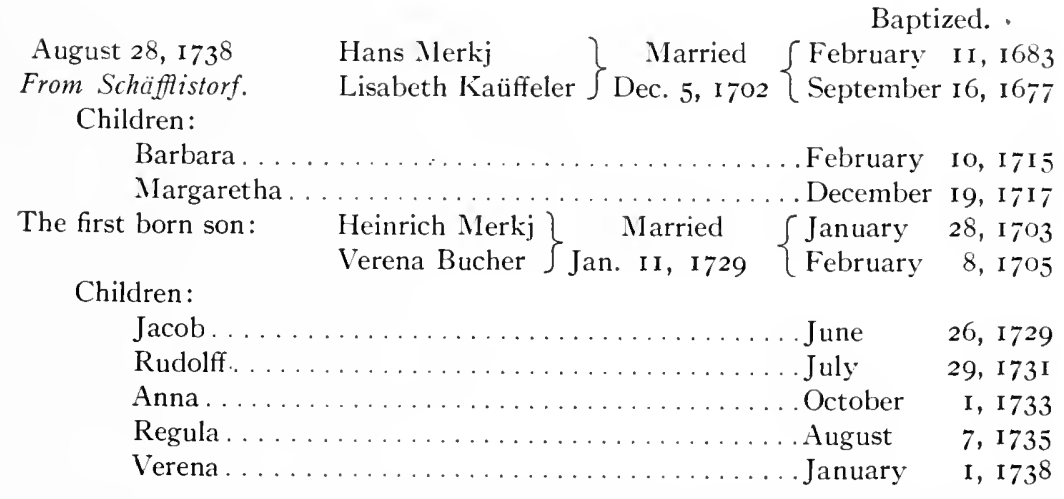

${ }^{5}$ The Rev. Jacob Lischy is mentioned a number of times in Hallesche Nachrichten, Vol. I. He was a minister of the Reformed Church, with friendly leanings toward the Moravians. A.B.F. 
From Oberwenigen. Susanna, daughter of the deceased

From Schlyniken. $\quad$ Hans Surber .................

April I 8, I 74I

From Oberwenigen.

April 21, 1743

Heinrich Rummen........... May

30,1713

Caspar Surber ] Married before (March

17,1716

I $4,17+1$. 7,1715

Hans, Jacob Duttweiler's son..... September I I, I 7 I 8

Hans, Hans Meyer's son........ October I2, I 72 I

Heinrich Surber, Jacob's son ...... May $17, \mathbf{1} 723$

Also from Oberienigen. Hans, Jacob Zöbelis' son . . . . . . . November 22, I 722

Catharina, the deceased Ehe-

gaumer Duttweiler's daughter...July $\quad 28,1726$

From Klupf.

Jacob Zöbeli Deceased Hans \{February 23, 17 6

Hans $\}$ Zöbeli's sons $\{$ Octcber 6, I 722

Total: 22 .

Attested, Haxs JacoB Karod:, March 26, I744.

\section{No. 74. List of those Persons who left the Parish Schwerzenbach to go to Carolixa}

I. Jacob Diethrich, Wilhelm Diethrich's son, born July 19, I7I6. Left in August, 1738 .

2. Also Hansz Ulrich Blatmann, born May 22, I703, and his wife Elsbeth Hoffmann from Uster, aged 43 years. Left May 2, I743, with five sons:

I. Christophel, baptized April 22, 1725 .

2. Rudolff, " July 5, 5733 .

3. Christoffel, " October 25, 1739(?)

4. Jacob, " "February 4, 1738.

5. Hans Heinrich, “ September I 8, I 740.

No. 75. Oberwinterthur, April 12, i744. Emigrants from the Parish Seen

Hans Wysz, aged 45 .

Els. Hofman, his wife, aged 35 .

Children:

Babelj, aged I 8 .

Betelj, " I 6 .

Vre. " "I3.

Anna, “ II.

Els. “ 9 .

Heinrich Bauer, aged 45.

Barbara Müller, 33 .

Children:

Heinrich, aged 5

Anna,

Urech Jeglj,

Vre Brunner,

Children:

Hans Urech, Io

Babelj,
36

9
1742

Elsbeth Huggenberger, aged i8, unmarried.

Anna Ehrensperger, 26. Childless widow.

Regula Müller, left without her husband, $\quad 36$

Hans Jucker, $\quad 36$ his wife Maria Müller, $3 \mathbf{I}$ 


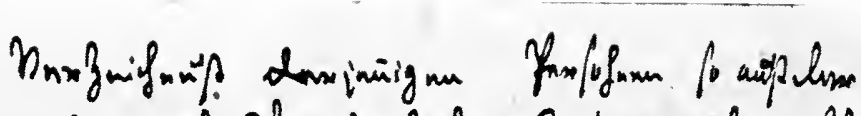

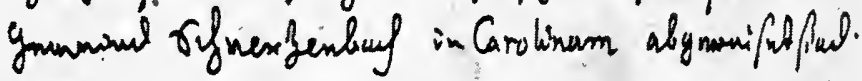

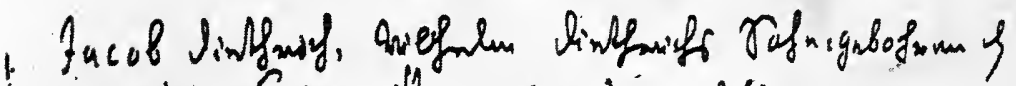

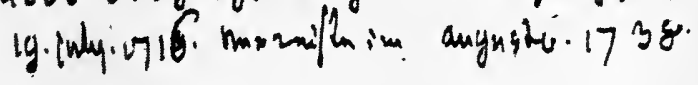

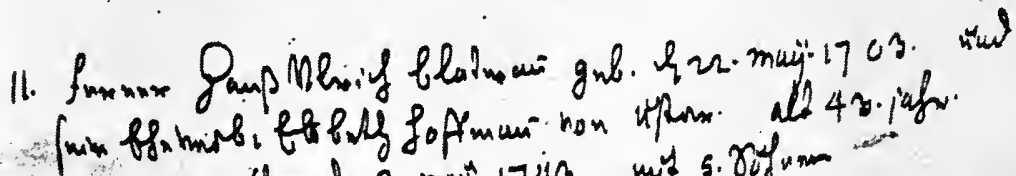

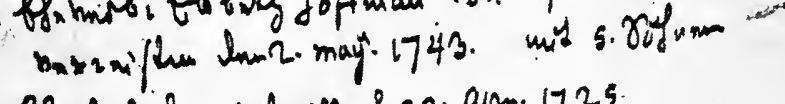

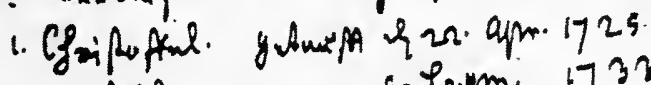

2.Hevilulf - 5. Leam 1732 .

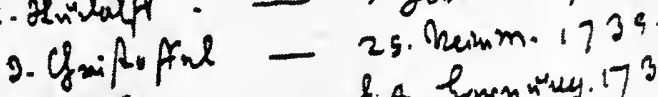

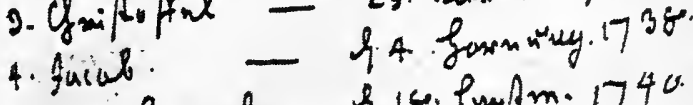

5 foupgriveref - \&18. Smpm. 740

Reprodection of the Original List No. 7 , Parish Schwerzenbach 

Jacob,

Hans Urich Jeglj, aged 24 his wife Els. Rösej, I9

Jac. Rüegg, aged 43

Barb. Büchj, $\quad 39$

Children:

Heinrich, 30 .

Jacob, 24 .

Ulrich, I2.

Konr, II.

Caspa:, 7 .
Children:

Babelj, $\quad 5$

No. 76. List of those Persons, Who since i734 Left the Parish Stadel for Carolixa Axd Pexisylyaxia, taken out of the registers kept by the parishes, by Hans Heinrich Gossweiler, Pastor.

Whole

Families

Persons

Anno $173+$ there left from Windlach

I. Hans Ulrich Auer, baptized December 5, I699.

Verena Eberhardt, his wife, baptized September 25, I70I.

Children:

Verena, baptized January 29,1725 .

Felix, " January 5, 1727 .

Hans Ulrich, " January I0, I 729.

Margretha, " March $5,1730 \ldots \ldots \ldots \ldots \ldots$

I 738 from Stadel

2. Hans Heinrich Lang, Büljorgen, the father, baptized December I3, 1674. Jung Hans, son, baptized April 9, 1705. Son's wife, Margareth Maag, baptized October 7,1704 .

Children :

Anna, baptized Nay 8, I73I.

Regula, baptized May 25, 1733 .

Johannes, baptized February I9, 1736.

Verena, baptized March $25,1738 \ldots$

3. Felix Huser, glaziei, baptized December 5, 1706.

His wife, Barbara Örtli, baptized April 25, I707.

Children:

Anna, baptized February I, I 733 .

Hans Jacob, baptized October $2,1735 \ldots \ldots \ldots \ldots \ldots \ldots \ldots \ldots+$

Heinrich Albrächt, called Kümin, baptized August 24, 1710......... I

Jacob Lang, carpenter, baptized September 28 , I 7 Io............. I Jacob Herzog, shoemaker, deceased Heinrich's son, baptized May 28,

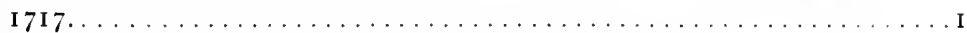

Jacob Albrächt, Rather's, baptized September I 8, I 72 I . . . . . . . . I Verena Huser, daughter of the mason Hans, baptized May 25, I 704...... I Jacob Wüst, son of deceased Leonhardt, baptized September 4 , I7 I $2 \ldots \ldots$ I

4. Felix Albrächt, drummer, baptized May 3, I691.

His wife, Anna Huber, baptized August $5,1683 \ldots \ldots \ldots \ldots \ldots \ldots \ldots$

Hans Huser, Leonhardt's son, baptized August I I, I 7 I $5 \ldots \ldots \ldots \ldots$ I

5. Hans Heinrich Albrächt, indoor weaver, baptized August $8,1709$.

His wife, Anna Merki, baptized April $29,1714 \ldots \ldots \ldots \ldots \ldots \ldots \ldots$ 
Hans Ulrich Albrächt, Hans' son, baptized September 17, 1719........ I

Hans Jacob Albrächt, captain, Joggeli's son, baptized January 24, 1717... I

6. Felix Albrächt, Balz's son, baptized September 1 8, I707.

His wife, Anna Schmid, baptized January 31, 1708.

His sister, Barbara, baptized September 18, I 7 1 $2 \ldots \ldots \ldots \ldots \ldots \ldots$

7. Heinrich Huser, wagon-maker, baptized January $21,1707$.

His wife Verena Huser, baptized, September 8, I 709.

Children :

Hans Jacob, baptized October 22, 1733.

Heinrich, baptized May I 5, 1735 .

Rägula, baptized February I0, $1737 \ldots$

8. Hans Albrächt, glazier, baptized August 9, I 696.

His wife, Anna Dübendorffer, baptized January 21, 1696.

Children:

Heinrich, baptized, March 5, 1724 .

Verena, July 26, I 732 . .

\section{From Windlach}

9. Felix Lang, called Stoffel Felix, baptized April i 2 , i 7 I 0.

His wife, Rägula Müller, baptized July 31, I 703 .

Children:

Hans, baptized July 3, 1735 .

Barbara, baptized January $30,1737 \ldots \ldots \ldots \ldots \ldots \ldots \ldots$

I0. Heinrich Schmid, Schmid's son, baptized March 28, I 706.

His wife, Verena Weidmann, baptized 1705 .

Child:

Hans Conradt, baptized March $19,1737 \ldots \ldots \ldots \ldots \ldots \ldots \ldots$

II. Hans Heinrich Lang, mason: baptized October 31, 1698.

His wife, Anna Vogel, baptized December 4, I 703 .

Children:

Anna, baptized April 4, I728.

Anna Barbara, baptized February 27, 1735.

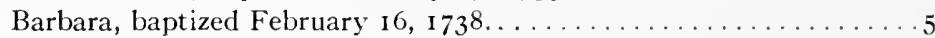

Hans Auer, Hans' son, baptized April $13,1716 \ldots \ldots \ldots \ldots \ldots \ldots$

\section{From Schüpfen}

Jung Hans Huber, Ehgaumer's son, baptized October I 4, I 70 .

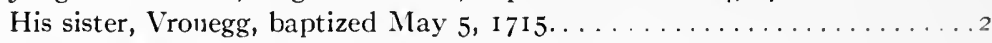

Rudolph Weidmann, deceased Joggli's son, baptized January i 4, I 7 16... I

\section{January 24, 1740. From Stadel}

Abraham Schmid, Heinrich's son, baptized February 4, I $720 . \ldots \ldots \ldots \ldots$. . .

Margareth Schmid, Joggli's daughter, baptized May 29, I $707 \ldots \ldots$. . . I

Anna Müller, Jung Hans' daughter, baptized May 26, i 7 I $5 \ldots \ldots \ldots \ldots$. . I

Elisabeth Land, deceased Heinrich's daughter, baptized September 27,

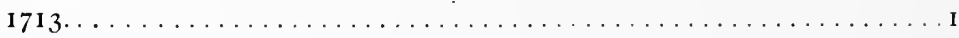

\section{From Windlach}

12. Hans Ulrich Schleher, baptized October 5, 17 I0.

His wife Barbara Müller, baptized March 24, 1705.

Children:

Heinrich, baptized December 6, 1733.

Johannes, baptized February 19, 1736. .

I3. Heinrich Lang, baptized September I, 1694.

His wife, Maria Mayer, baptized February 14, I7 12. 
Children:

Hans, baptized November 16, I 726.

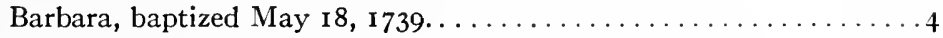

14. Felix Huser, baptized November 22, 1707.

Barbara Mayer, his wife, baptized December $8, \mathbf{1} 709 \ldots \ldots \ldots \ldots \ldots \ldots$

\section{From Rath}

I5. Hans Lang, baptized November 28, I686.

His wife, Anna Meyer, baptized May I3, 1697.

Children:

Esther, baptized January I5, I72I.

Felix, baptized March I4, I724.

Anna, baptized July 3I, I729.

Jacob, baptized December I, I 737 . .

16. Hans Cunz, Peter Heiri, baptized July I4, I695.

His wife, Veronica Lang, baptized May 2I, I693.

Children:

Anna, baptized May 22, 1729.

Hans Jacob, baptized December 2I, I730. . . . . . . . . . . 4

17. Jung Hans Cunz, baptized February 5, I697.

His wife, Elszbeth Lang, baptized December I9, I697.

Children:

Rägula, December 19, I 720 .

Veronica, baptized May 2, I 734 .

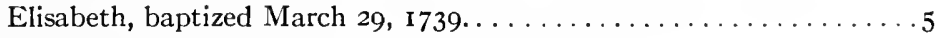

\section{April 25, I743. From Stadel}

18. Vronegg Auer, Felix Lange's widow, baptized December I I, I708.

Children:

Johannes, baptized August 22, I 734 .

Margaretha, baptized September $1,1737 \ldots \ldots \ldots \ldots \ldots \ldots \ldots$

I9. Jacob Schmid, carpenter, baptized January 24 , I 688.

His wife, Elisabeth Duttweiler, baptized November 15, 1696.

Children:

Barbara, baptized April 25, 1723.

Jacob, baptized August 19, 1732 .

Hartmann, baptized July 20, I 735 .

\section{From Windlach}

20. Heinrich Köchli, baptized May 4, I704.

Elszbeth Meyerhoffer, his wife, December 20, 1699.

Children :

Verena, baptized September 22, I726.

Cleophea, baptized July I I, I 728 .

Anna Maria, baptized August 16, 1733 .

Hans Jacob, baptized August II, 1737 .

Barbara, baptized March 19, I $741 \ldots \ldots \ldots \ldots \ldots \ldots \ldots \ldots$

\section{From Rath}

21. Hans Rudolff Meyerhoffer, baptized August i8, I689.

His wife Margaretha Bersinger, baptized 1695.

Children:

Hans Rudolff, baptized June I, I72I.

Johannes, baptized April 25, 1723. 
Hans Ulrich, baptized December 9, I73I.

Anna, baptized May 8, 1729.

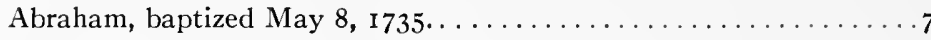

22. Hans Meyerhoffer, baptized August 27, 1694 .

Children:

Hans, baptized February 12, I 726.

Anna, baptized July 19, 1733 .

Margaretha, baptized February 22, $1735 \ldots \ldots \ldots \ldots \ldots \ldots \ldots \ldots$

23. Heinrich Moor, baptized February I7, I 7 I I.

His wife, Barbara Lang, baptized July I 2, I 7 I I.

Children:

Felix, baptized September I3, I 739 .

Hans Jacob, baptized November 27, I740.

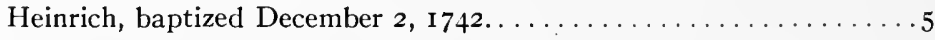

Jung Hans Lang, Deker's son, baptized July $25,1686 \ldots \ldots \ldots \ldots \ldots \ldots$ I

24. Heinrich Huser, baptized December 5, I697.

His wife, Rägula Mayer, baptized July 24, I698.

Children:

Rägula, baptized March 23, 1725 .

Anna Barbara, baptized July I3, 1726.

Johannes, baptized August 27, 1730.

Christoph, baptized October I 8 , I 733 .

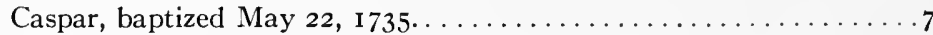

25. Felix Mayer, so-called Hospel, baptized December 30, 1703 .

His wife, Veronica Schmid, baptized May 29, 1707.

Children:

Jacob, baptized January 30, I729.

Hans Ulrich, baptized December I6, I73I.

Johannes, baptized April 2, I733.

Anna, baptized February 20, I735.

Veronica, baptized October 3, 1736 .

Johannes, baptized September 26, I739.

Verena, baptized March $26,1741 \ldots \ldots \ldots \ldots \ldots \ldots \ldots \ldots$

Suszanna Kämpf, daughter of Hans deceased, baptized August 7, I7 I9. . . I

Anna Mayer, Hans Koch's housewife, baptized January Io, I691........ I

\section{- March 27, 1744. From Stadel}

Margaretha Albrächt, daughter of deceased Felix, baptized October 24, I 723 .

Total of all who left from the whole parish, 138 .

Total 25 families.

No. 77. From the Parish Steinmur from i734-1744 THere LEFT FOR CAROLINA

1734. From Obersteinmur

I. Hans Müller, baptized September 25, I707.

Anna Weidmann, baptized March 16, I704.

Children:

Anna Maria, baptized July 23, 1730.

Hansz, baptized February 15, I 733 .

His brother:

Heinrich Müller, baptized May 29, I $7 \mathbf{1 2}$.

2. Heinrich Surber, wagon-maker, baptized March 20, I683.

Anna Hinnen, baptized January 24, 1685. 
Children:

Hans Caspar, baptized November 29, 1707.

Hans Heinrich, baptized January 8, 1719 .

Verena, baptized June 5, I729.

\section{8 in August}

3. Caspar Koch, smith, baptized August 4, 1700.

Verena Müller, baptized September I, I 700 .

Children:

Verena, baptized October 8, I 724 .

Rodolff, baptized March 14, 1728.

Anna, baptized June $\mathbf{1} 8, \mathrm{I} 730$.

Barbara, baptized November 16,1732 .

Beat., baptized March 26, I 735 .

Caspar, baptized March 24, I 737 .

4. Heinrich Meyer, Tisen, baptized September I, I695.

Anna Trub, baptized July 26, I 7 I I.

Children:

Hans Jacob, baptized October I3, I 720.

Verena, baptized May 15, 1729.

Lienhart, baptized August 28, 1735 .

Margreth, baptized December I, I737.

I74I, in March. From Obersteinmur

5. Hansz Surber, baptized November 23, 1690.

Verena Surber, baptized October 9, 1675 .

6. Heinrich Weiszmüller, baptized February 26, I 706.

Barbara Schmid, baptized October 9, I690.

7. Hans Koch, Michel's son, baptized August I4, I68I.

Verena Meyer, baptized June 6, 1686.

Children:

Cleophee, baptized August 2, I716.

Cathrj, baptized February I 8, I720.

Son:

Regula, baptized November 5, 1724.

Joseph, baptized March I, I7I3.

Child:

Kljannj Meyer, baptized June Io, I7 I 5 .

Maria, baptized January $8, \mathrm{I} 74 \mathrm{I}$.

8. Heinrich Köchlj, joiner, baptized November 20, I707.

Margreth Vogler, baptized June 27, I 7 I6.

Children:

Johannes, baptized February 27, $173^{8}$.

Felix, baptized January 29, I74I.

9. Heinrich Huber, cabinet-maker, baptized January Io, I686.

Barbara Bleüler, baptized September 26, I 706.

Children:

Anna Magdalena, baptized January I, I 736.

Barbara, baptized February 24, I 737.

Anna, baptized April 23, 1741.

N.B. Has also with him his wife Barbara, baptized January $3 \mathrm{I}, \mathrm{I} 734$.

$\mathrm{He}$ is living at Friedrichsthal in the Margravate-Baden-Durlach.

1743 in May. From Obersteinmur

Io. Hansz Koch, sergeant, baptized January 3I, I 708.

Verena Müller, baptized September 2, I 703 . 
Children:

Anna, baptized April 29, I73I.

Hans, baptized April 26, 1733 .

Kljannelj, baptized April, I735.

Regula, baptized October 5, 1738 .

Johannes, baptized April I6, I74I.

1738, August. From Nidersteinmur

I. Hans Meyer, baptized January II, I69I.

Kljvree Huber, baptized January I4, I690.

Children:

Verena, baptized October 25, I716.

Verena, baptized September 9, I 723 .

Barbara, baptized December 8, I726.

Regula, baptized June 6, I728.

Jacob, baptized June II, I730.

Anna Margreth, baptized May II, 1734 .

2. Caspar Lips, baptized June 25, 1695 .

Regula Näff, baptized November 5, 1693.

Children:

Heinrich, baptized July $28, \mathbf{1} 726$.

Anna, baptized May 6, I 728 .

Hans Caspar, baptized January 7, I73I.

Felix, baptized May I6, I 734 .

174I, April. Also from Nidersteinmur

3. Hans Heirj Frölj, baptized March 28, 1700.

Anna Huber, baptized October I, I 702.

Children:

Heirj, baptized July 6, I732.

Hans Jacob, baptized April 4, 1734 .

Anna, baptized November I I, I736.

John Baptista, baptized December II, I740.

N.B. This man is said to have taken with him over one hundred pounds, but after he had squandered this sum, returned with his whole household. The women and children wander about as beggars. He serves for a time in a place, but not too long. But at Nidersteinmur he is no longer tolerated.

4. Hans Jacob Trub, baptized February 28, 1717. Jacob's the mender's son.

I. Two brothers:

1738, August. From Sünnicken

$\left.\begin{array}{l}\text { Heinrich Zweidler, baptized May 31, I716. } \\ \text { Mathys Zweidler, baptized December 25, I 723. }\end{array}\right\}$ Hans Heiri's sons.

2. Two brothers:

Heinrich Volkhart, baptized November I7, 17 12. $\}$ The deceased Jacob Volk-

Hans Heinrich Volkhart, baptized July 4, 1717.$\}$ hart's sons.

3. Heirj Bräm, baptized June I7, I712. Deceased Felix Bräm's son.

$$
\text { I741, March }
$$

4. Hans Huber, glazier, baptized February $7,1688$.

5. Hans Ulrich Huber, carpenter, baptized March 20, I698.

Margreth Weidmann, baptized March II, 1697.

Child:

Lienhard, baptized October 3, I730. 
Mother of the above Huber:

Anna Zweidler, baptized April 20, I67I.

Sister-in-law:

Regula Weidmann, baptized December 22, I709.

\section{Also from Sünnicken}

6. Heinrich Weidman, mender, baptized November 4, I703.

Anna Zweidler, baptized March 28, 1709.

Children:

Heinrich, baptized February 1735 .

Hans Jacob, baptized June 22, I 738 .

Anna, baptized June I2, I740.

\section{I738. From Neerach}

I. Heinrich Huszer, baptized June I3, I697.

Anna Bucher, baptized January 25, I69I.

Son:

Felix, baptized September 6, I722.

\section{743}

2. Johannes Albrecht, wagon-maker, baptized February I3, I70I.

Magreth Moor, baptized January 23, I 707 .

Children:

I. Verena, baptized March 25, I728.

2. Hans Jacob, baptized November 6, I 729 .

3. Jacob, baptized February II, I73I.

4. Felix, baptized March I4, 1734 .

5. Annelj, baptized February 7,1740 .

6. Regina, baptized July 22 , 1742 .

$$
\text { 1743, May }
$$

3. Annelj Kuenz, baptized October 5, i710. Daughter of the deceased magistrate (Vogt) Heiri.

$$
\text { I } 74 \mathrm{I}
$$

4. Barbara Kuenz, baptized March I2, I7I9. Johannes', the carpenter's daughter.

I 738

5. Melchior Meyer, baptized August 3, I7 10.

Anna Barbara Meyer, baptized August 20, I 7 I3.

6. Anna Müller, baptized September I5, I 700 .

Illegitimate child of Melcher Streiff, tailor's help-mate from Glarus.

Hans Jacob, baptized September 24, 1729 .

\section{743, May}

7. Barbara Albrecht (spinner), baptized July 21, I 720.7 Jacob Albrecht's Margreth Albrecht (spinner), baptized February I5, I722. $\}$ (called Wägeli) Regula Albrecht, baptized August 31, I723. daughters.

8. Margreth Kuenz, baptized October 5, I72I. Heinrich Kuenz's (called "Engelheinrich") daughter.

\section{8, August. From Rieth}

1. Cathrj Kuenz, baptized April I 4, I7 I5. Three brothers and sisters, Heirj Kuenz, baptized July 6, I719. Annelj Kuenz, baptized February 15, 1722. $\int \begin{aligned} & \text { children of } \\ & \text { Hans Kuenz. }\end{aligned}$ 
2. Jacob Kuenz, baptized October 6, I715. Deceased Hans Heinrich Kuenz's son.

3. Heinrich Schellenberg, baptized December 20, i716. Felix's son.

\section{No. 78. From the Parish Sternenberg there left on April 16, 1743, the Following Families}

(a) Hansz Rügg, 43 years, and his wife Elsbetha Ott 35 years of age, with their five children, the oldest of which was 12 years and the youngest Io weeks old.

(b) Felix Rebsamen, 45 and his wife Regula Graff 39 years old, with 6 children, the oldest of which was I 5 years and the youngest I year old.

After selling his house and goods, and paying the emigration tax on the total, each of these men took away with him about 300 florins in money.

Attested ex-officio, Heinrich Sprüngli, Pastor.

Sternenberg, May 5, I744.

\section{No. 79. Anno i738, there left Töss, from the Estate Tetrau, Two Families for Carolina}

1. Parents:

Children:

Jacob Meyer, born I695.

Elisabeth Hofmann, from Ober-Schotti-

Heinrich, born April 28, I 725 .

ken.

Elsabeth December 9, I 726

$\begin{array}{lll}\text { Catharina } & \text { January I, I } 1735 .\end{array}$

Jacob September I2, I737.

2. Hans Heinrich, born I709.

Barbara Keller, from Jsliken.

$\left\{\begin{array}{llr}\text { Hans Jacob } & \text { April } & \text { I4, I733 } \\ \text { Elsbeth } & \text { October } & 23, \mathbf{1} 735 \\ \text { Hans Geörg } & \text { April } & 7, \mathbf{1 7 3 8}\end{array}\right.$

Note: Concerning these two families I have not been able to learn up to the present, in spite of frequent inquiries, where they got to.

Anno July 3I, I743 .

Has gone from Tosz to Pennsylvania with wife and child:

Parents:

Child:

$\left.\begin{array}{l}\text { Hans Caspar Siber, born June I2, I7 I 7. } \\ \text { Elsbetha Klaüe, born September 8, I707. }\end{array}\right\}$ Anna, October 25, I739.

Note: Concerning this family the report was circulated in the first four weeks, that the father and the child has died at Basel. ${ }^{6}$ But since then nothing has been heard, whether this rumor be true or whether they travelled farther.

\section{No. 8o. TRÜLlikON}

From this parish and all four sections of it, since 1734 there was no one with the intention of going to the new-found-land, except:

Conrad Wieland, from Trutikon, who faithlessly left his wife, on account of bad management, at the end of the year $173^{2}$, and I do not know whither he has gone.

I. Anna Engeler, his wife, born July I, I693, with four children: (I) Lisab., born March 23, I718. (2) Hans Rud., October 6, I720. (3) Urss., August 25, 1723. (4) Hans Conrad, May io, I73I.

${ }^{6}$ The same sold her house and goods in October, and after she missed getting away the first time, and $I$ in the meantime had spoken to the magistrate of Toggenburg about these people, she left with the rest of her means and children. Where they got to, God knows! 
2. Elsbeth Hablüzel from Trüllikon, who however first married Herman Gyger from the parish Diebolzau in Rhynthal, February 26, I734. He is said to have taken away from his father, etc., according to an understanding with him, about 800 pounds.

From their destination the man wrote to his poor brother-in-law and relatives, as I have seen and read in the letter, that he was getting along well, he had plenty of food, and if they wished, they should come to him. Enough to eat and also to work they would find with him; if they could only provide for themselves as far as England, he would from there on pay their passage, but with the provision, that they would pay back the outlay with work. But on my advice they remained, but had not the old sister-in-law died, and if poverty did not hold them back, I do not know what they would do.

Hans Ulrich Vogeler and his wife Elsbeth Peyer from Trüllikon with two children, who are overloaded with debts and would make more if they could, are also anxious to go, but poverty holds them back. But they have stirred up another neighbor, who has no children and an infirm wife, that he should sell his property and go along, etc.

But he wished that he and his wife and his surplus 200 pounds be put under the care of the hospital, before their property should grow less. I started negotiations for them, but was told that for a married couple there was no room.

Therefore I proposed another plan to His Honor the Governor, which was feasible in case these people would desire more assistance. I tell you this, so that you may see what efforts are necessary, and that Christian care with its seriousness is very much needed.

Martj Zehender, a young unmarried man, petitioned his older brother Hans Ulrich, he should give him 18 pounds, so that he might on Easter Monday go forth with those from Andelfingen to Carolina, and he would no longer then as before come to him in bad clothes and be a burden to him, and would also make no further claim to his inheritance. On that he would give a written pledge.

I said, that if he wished to give up his citizen's rights, he could apply at the proper place, but if not, his honest brother should not spend money as for the interest, and let the good-for-nothing waste it. After squandering it, he would come back, and then he would have to support him again.

This report I am glad to furnish, so that our poor people be spared needless governmental expenses. If the saving were only carried through in all things, particularly as concerns widows and orphans. For if despair once adopts another road, conditions would really be very bad, because God's severe judgment is to be feared.

April 25, I 744.

Pastor Caspar Brunner.

\section{No. 81. From the Parish Turbenthal the Following have gone to Carolina}

February I743. Catharina Rüegg, legitimate daughter of Hans Heinrich Rüegg, from the Ramsberg. Baptized November I5, I7II.

March I743. Johannes Büchj, Postumous, legitimate son of Rudolph Büchj, deceased, from Neubrunn. Baptized December I4, I72I.

Turbenthal, April 23, I744.

Attested, Pastor ScheÜchzer.

\section{No. 82. UHWISEN}

Very Revered, Learned, Honored Minister and Dean:

In reply to your gracious command, etc., etc., I report as follows: About three years ago, four heads of families, possessed of many children, announced 
themselves to me and truly sought counsel as to whether they should go to Carolina, but on my representations they yielded at once, so that up to date, God be thanked, no one is known to have gone thither out of my parish. Those that are in military service were specified a year ago and sent to the high authorities; for their glory was but half as great as the seducers claimed. With a well provided Divine service, I should be pleased to care for 40 families or more. With salutations etc.,

Uhwisen, April 6, I 744 .

Joh. Heinrich Heitz, Pastor.

P.S. What happened at the visitation of BANKEN, will undoubtedly have been reported by his Honor Chamberlain Wirth, etc., etc.

\section{No. 83. URDORFF}

To go to Carolina and lands about there, since 1734 , no one left this parish of Nider-Urdorff, nor the middle or lower Räbstal, but two unmarried boys:

Jacob Grob, son of Hans Grob, 37 years old, and

Felix Huber, son of the deceased Jacob Huber, aged 35 years, who up to this served under peasants at other places, and on the 16 th of July, I 743, without permission of the authorities, and without a certificate of baptism left the country. But because the latter left behind a woman with a child, to whom he was betrothed, named Verena Lips, daughter of the deceased Melcher Lips, from this place, who suspecting his departure, followed him to Basel, but could neither overtake him nor find out anything about him, the matter was brought before the marriage court, November 5,1743 , the promise of marriage nullified, the child declared legitimate and with the right of inheritance, and its bringing up put in charge in the meantime of his brothers Caspar and Heinrich Huber. This is a pattern of what fruits the emigration-fever grows and leaves.

\section{Urdorf, April 3, I744. Attested, Johann Jacob UlRich, Pastor.}

\section{No. 84. List of those Persons who left the Parish Uster For Carolina}

Jacob Frey, sergeant, son of the deceased Heinrich Frey, from Sultzbach, baptized I695, December I, aged 48 years and II months, left for Carolina September 5, 1736, with his wife Regula Appert,* baptized January 8, I699, aged 45 years and 3 months, with three children: Anna Barbara, baptized December I 7, 1724, aged 19 years and 3 months; Elsbetha, baptized January 30, 1725, aged I 8 years, 3 months; Heinrich baptized October 24, I728, aged I 5 years, Io months.

With him there has gone to Carolina also Hans Jacob Homberger, from Sultzbach, a boy of 17 years, 2 months. Has neither wife nor child, brothers nor sisters.

Hans Wolfensperger, sergeant, son of the deceased Hans Wolfensperger, from Kirch-Uster, baptized August 26, I 706, aged 37 years, 7 months, also went to Carolina in 1743, in September, with his wife Anna Regina Huber, baptized January 10, I7II, aged 33 years and 3 months, with four children: Regula, baptized March I, I 73I, aged I3 years, I month; Elisabeth, baptized January I, 1735, aged 9 years, 3 months; Anna, baptized October 28, 1737, aged 7 years, 5 months; Cleophea, baptized March 26, I739, aged 5 years.

Attested, Johannes Schwytzer, Vicar at Uster.

* Note: He is not in Carolina, but in the Spanish service, his wife and children with Hans. 


\section{No. 85. FehraltorfF}

Ulrich Stutz, baptized May 27, I688.

Elisabeth Ochsner, from Zimikon, the parish Volkenschweyl.

Married here September 4, 1731. After selling all their property, which netted 200 pounds, left here for Carolina, August 29, I 738.

Children of the above:

Heinrich, baptized, May 28, 1732.

Caspar, baptized November 20, 1735.

Barbara, baptized July 14, I737.

For their children's sake they took with them:

Hans Wolgemuth, Hans' posthumous son, a very poor boy, baptized April 2, I 719.

Concerning these no certain report has been obtainable. In the meantime there was a rumor, that they suffered shipwreck, and with a great number wretchedly went to their doom.

Just at the same time there went away from here, to go to Carolina:

Hans Jacob Bachofen, baptized November 25, 1703.

Cleophela Wolgemuth, baptized August I6, 1707 .

Married couple wedded here December 13, I 735 .

At Basel they were dissuaded from their purpose. The woman came back, the man, however, sought a livelihood elsewhere, and found it with a charcoalburner in Alsace, where he remains in a wretched condition.

This honest and pitiable man might have very well earned his bread here with weaving woolen fabric. But his wife in her evil ways not only deprived him of his food and household goods, but even abstracted some of the wool-yarn, so that he could not return the full weight, and finally lost him employment, which reduced him to this sad extremity. The above mentioned woman has now become vagrant, so that in spite of all inquiries, I do not know where she may be.

Margreth Gut, from the Senscheür, a fief depending upon Kyburg, baptized October 14, 1718, married here May 23, I742, to Rodolff Brüngger, a carpenter by trade. She could not get along with her husband and father-in-law, departed from here without taking leave, June $28, \mathrm{I} 743$, to join those from Dägerlen reported to be going to Carolina. She went with a woman who was following her husband, a smith, who had journeyed thither in order to help support his children on wages promised him.

For the rest I am quite sure, that now no one else in the parish has a leaning toward the so-called New-found-land.

Fehraltorff, April 2, 1744. Thus testifies Hans JacoB Wirtz, p.l.

\section{No. 86. List of those who SINCE I734 LefT the Parish Volket- SCHWEILER TO GO TO CAROLINA}

Born I698, Heinrich Hegetschweiler, February 20. These left in the preI697, Barbara Buchmann, his wife, September 26. $\}$ ceding year, I742.

Children: Margaretha, born 1719, in October; Anna, March, 1720; Susanna, September, 1722; Anna Barbara, May, 1724; Heinrich, August, 1726; Hans Heinrich, August, I728; Beat. Rudolff, August, I73I; Jacob, - I739; Verena, April, 1736.

Total 4 sons and 5 daughters.

From Zimickon
$\begin{aligned} & \text { I694, Caspar Hesz, and } \\ & \text { I706, Anna Knecht, his wife. }\end{aligned}$ These also in the 4 2nd year (1742).
Child: Hans Rudolff, born April I739.

Margretha Knecht, sister of the above Anna, unmarried, born May, 1708 . 
$\left.\begin{array}{l}\text { 1699, Hansz Ochsner, April 29, and } \\ \text { Anna Zuricher, October 22. }\end{array}\right\}$ These left 3 years ago.

Child: Hans Jacoblj, born November, 1737.

Volketschweil, attested April 2, I744.

J. H. Frey, Pastor.

\section{No. 87. Wädeschweil. (See Plate i i)}

Highly Revered, etc., Dean! I have the honor, in reply to the circular received, to inform the Highborn, etc., Dean that no more, as far as we can learn, have left Wädeschweil for Carolina, than,

I. Johannes Theiler, baptized October 8, 1690 and his wife,

Margretha Meyer, baptized, September 8, I698.

Also their son with his family, to wit:

2. Hans Jacob Theiler, baptized December 3, I7 3 .

Magdalena Belon, from the Dauphiné, baptized September I5, I737.

Children: Hans Rudolff, baptized September I 5, 1737.

Elisabeth, baptized January I2, I 739 .

Joining them and leaving his wife, Anna Tobler, behind:

3. Hans Heinrich Baumann, baptized March 23, I673.

This departure took place in April, I739. It was rumored that old Theiler, the father of Johannes, died on the way. Hans Jacob, as much as two years ago, sent back a letter in which he praises his good fortune and the new land. Other than these, thank Heaven, I know of none from my parish, who were possessed by the desire to emigrate.

Wädeschweilen, April го, I744.

. Obedient Servant,

Jos. Caspar Hofmeister, Pastor.

Fron the Parish Schönenberg no one was so perverse as to Go

No. 88. List of Persons from the Parish Wallissellen, who SINCE THE YEAR I734 LEFT FOR CAROLINA

Married people. Left October 5, I734. Baptized.

I. I. Hans Heinrich Merki................... June 3, I688

2. Elsbeth Wezstein, wife.................... 30, I693 Children:

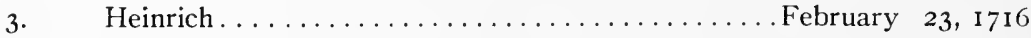

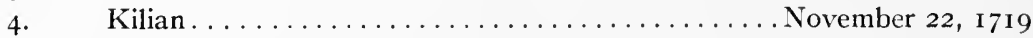

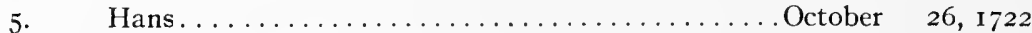

6. Hans Conrad .......................................

7. II. Konrad Näff...................... July II, I680

8. Ana Barb. Däppeler, wife..................... 2, 1686 Children:

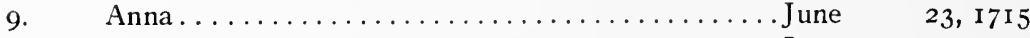

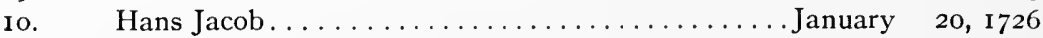

II. Hans Jacob (same name) .................. January 25,1728

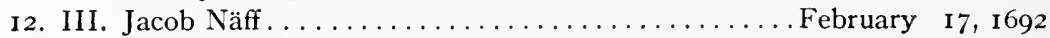

13. Lisabeth Kuhn, wife.................. December 15, 1695 Children:

I4. Anna........................... 28,1720

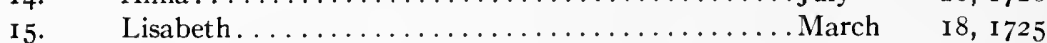

I6. IV. Hans Conrad Keller, carpenter................... . I4, I706

17. Barbara Blaar, wife................................ 9, I703 


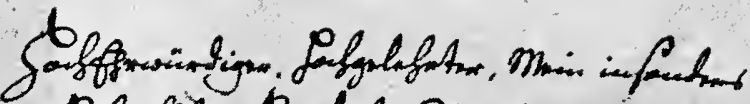

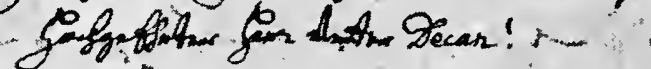

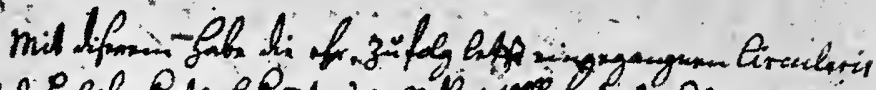

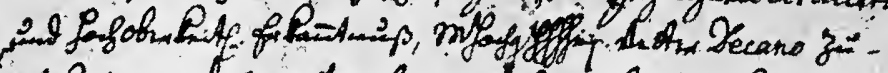

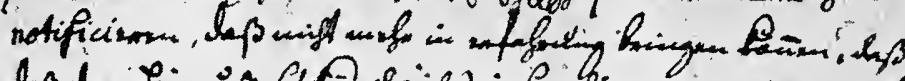

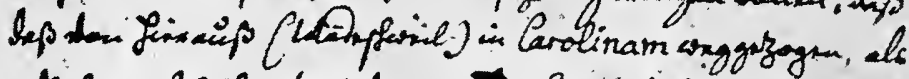

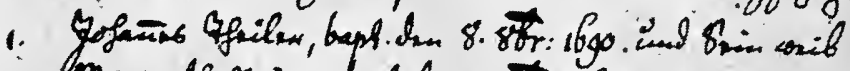

mangentfa mejos. bapt, hm 8. Tor: 108g.

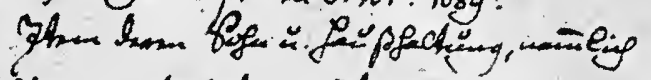

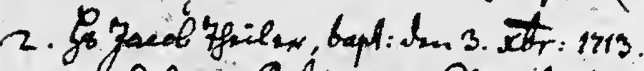

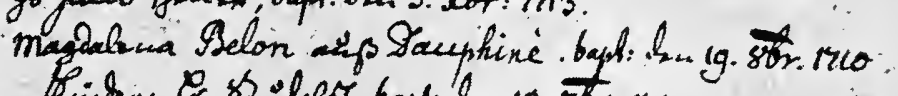

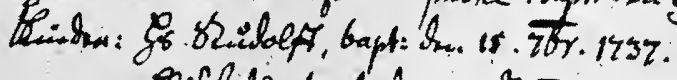

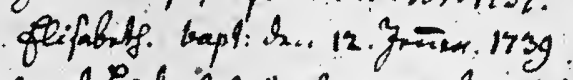

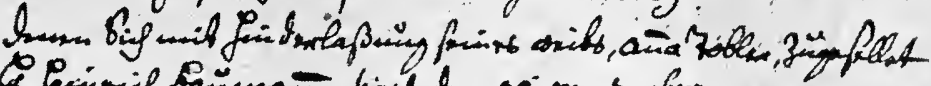

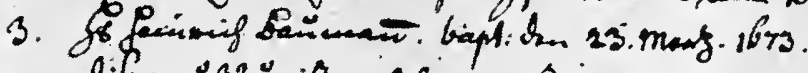

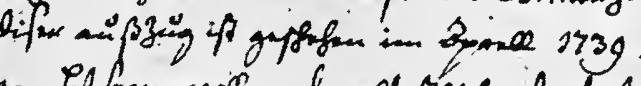

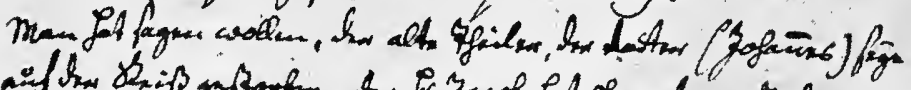

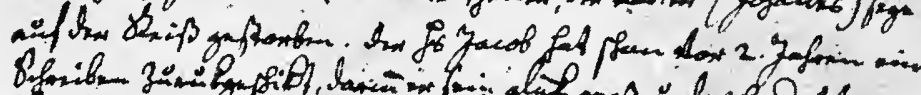

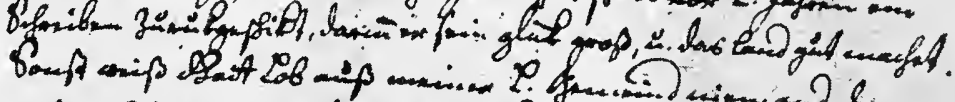

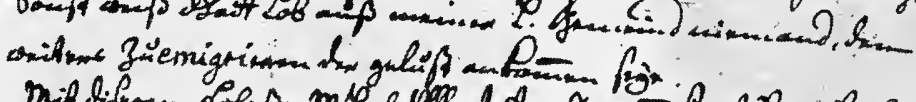

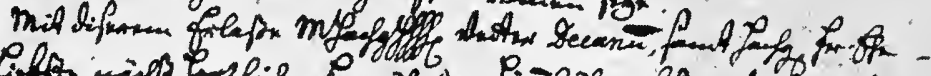

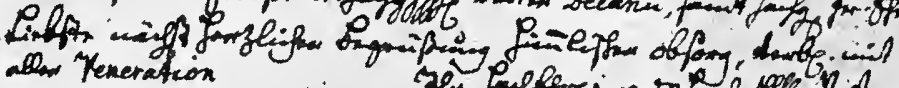
Aforfer of w. Apr: $12+4$.

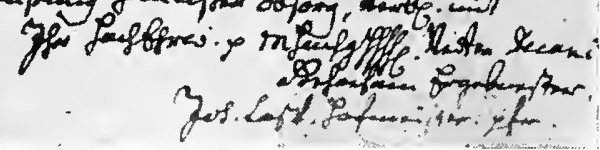

Reproduction of the Original List Ño. 87, Wädeschweil 

Child:

18. Matheus........................ July 25, I734

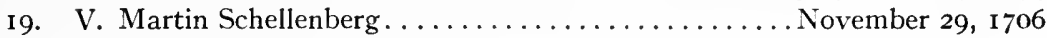

20. Verena Benz, wife........................ I3, I7I3

2I. VI. Jacob Näff, above Conrad Näff's son.......... December I, I7 I0

22. Elsbeth Haller, wife....................... 24, I7 I I

Unmarried people.

23. Barbara Haller, daughter of Hans Geörg......... October 7, I708

24. Hans Conrad Näff, deceased Ulrich's son..........April 30, I713

25. Ursula Schellenberg, above Hans Martin's sister ... July 4, I7 I I

26. Hans Jacob Rathgeb, son of Jacob deceased...... July 29, I708

27. Jacob Wüest, son of Hans Heinrich................ I I8, I7I4

28. Hans Rudolf Aeberli, son of Jacob deceased....... September I I, I 7 I 2

29. Hans Ludwig Lienhardt, son of Heinrich........ July 26, I7 I2

Married.

$$
\text { Left on May 6, I743 }
$$

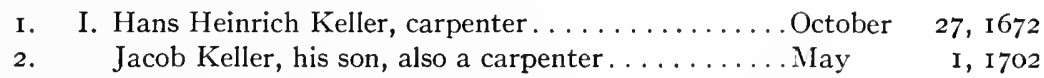

3. Anna Näff, wife.............................. 2, I702

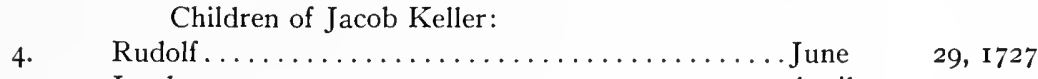

5. Jacob.............................. I7, I729

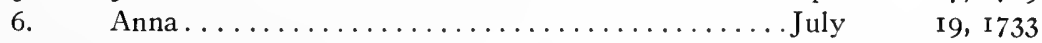

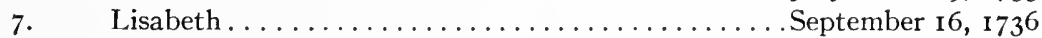

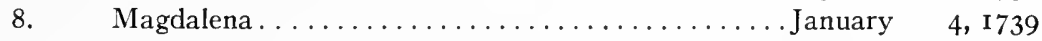

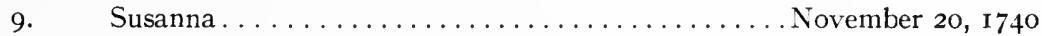

Io. II. Rudolff Näff............................ $\quad 25,1679$

II. Hans Näff, his son, the above Hans Heinrich

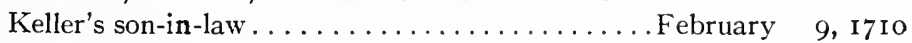

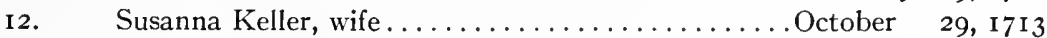

Married.

There left on May 8, I743

I. I. Hans Heinrich Näff . . . . . . . . . . . . . . . March 29, I692

Lisabeth Winsch, wife................. January 7,1703 Children:

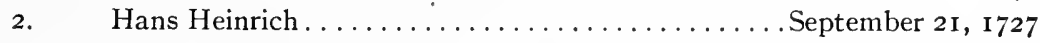

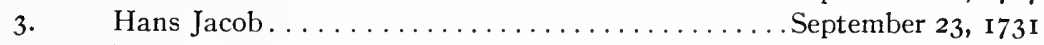

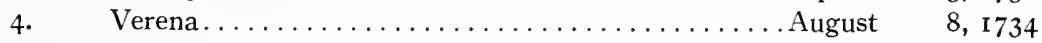

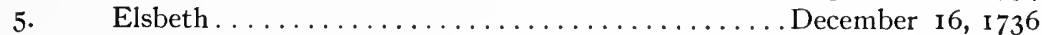

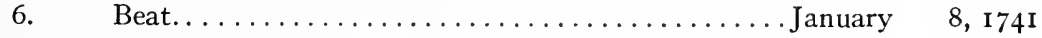

7. Barbara................................ $17, \mathrm{I} 743$

9. II. Hans Jacob Näff, brother of the above............ November I4, I697

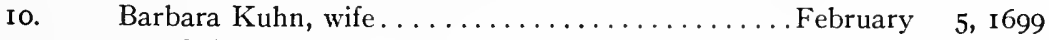
Children:

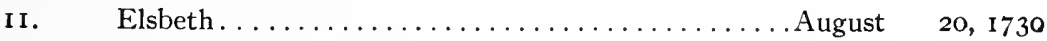

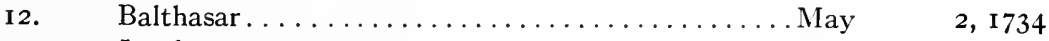

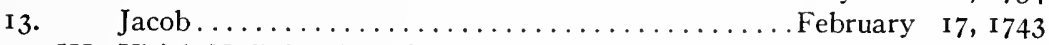

14. III. Ulrich Näff, brother of the above..........March I8, I703

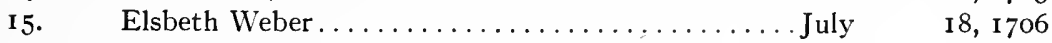
Children :

I6.

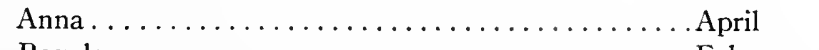

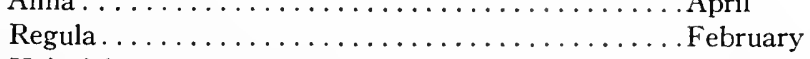

28,1726

I7.

I 8 .

Heinrich . . . . . . . . . . . . . . . February

20,1729

20,1735 
Unmarried.

19. Anna Barbara Näff, daughter of Hanz Näff, school-

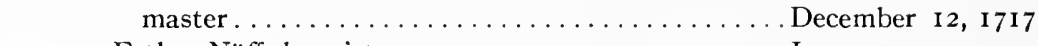

20. Esther Näff, her sister ............... June I I, I7 19 Total: 6I persons.

No. 89. List of Persons, who from i 734-I 744 FoOlishly left the Parish Wyach to go to other strange Countries

Anno $1734 \quad$ Born

Heinrich Meyerhofer, Rudolf Meyerhofer's son . . . . . . . . . . . . . I 703

Hans Heinrich Meyerhofer, Rudolf Meyerhofer's son . . . . . . . . . . . . I 709

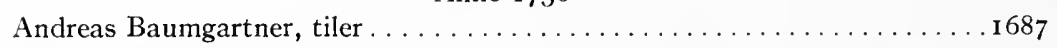

Barbara Meyer. . . . . . . . . . . . . . . . . . . . . . I 697

Children:

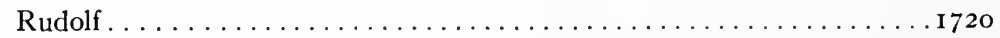

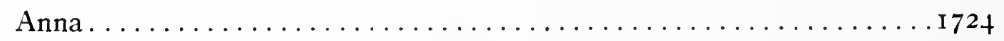

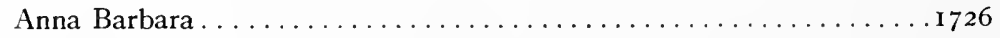

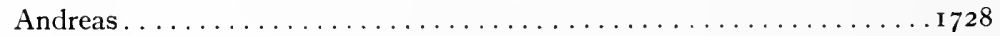

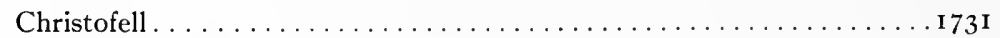

Heinrich Baumgartner . . . . . . . . . . . . . . . . . . . . . . 687

Barbara Griesser . . . . . . . . . . . . . . . . . . . . . . . 688

Children:

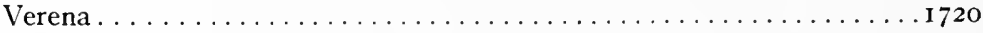

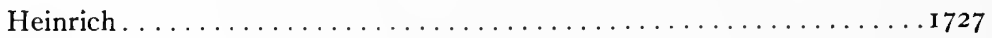

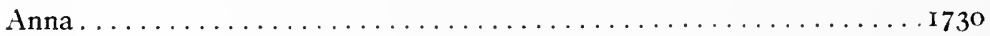

Maria Baumgartner, widow . . . . . . . . . . . . . . . . . . . 679

Children:

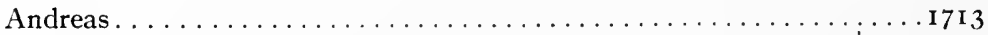

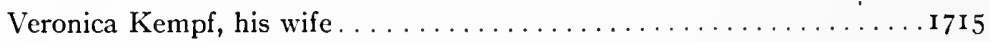

Anna ........................... . .

Heinrich.............................

Hans Meyerhofer ................................ I689

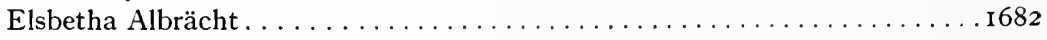

Children:

Hansz ................................ $77_{26}$

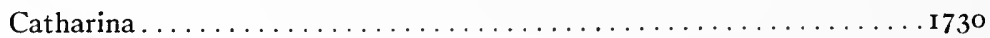

Rudolf Meyerhofer.............................. 673

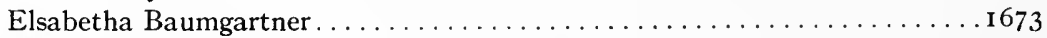

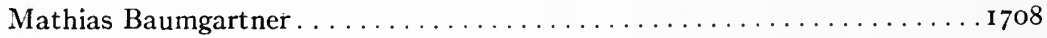

Susanna Meyerhofer. . . . . . . . . . . . . . . . . . .

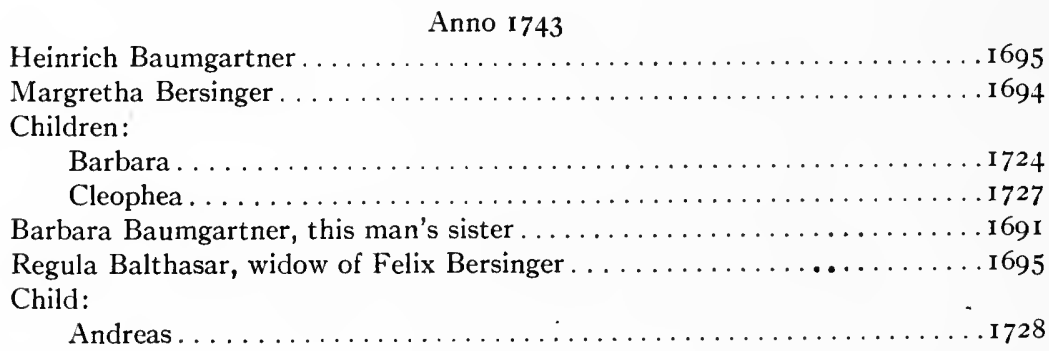


Anno 1744

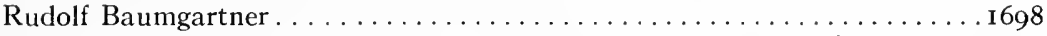

Barbara Meyerhofer........................... . 688

N.B. Margretha Albrecht, from Stadell, who served with this Baumgartner, and is said to be with child by him.

Total: 36 .

WoLF.

April I4, I 744 .

\section{No. 90. List of Persons who left the Parish Wenningen For Pennsylvania and Carolina}

I734 Hansz Caspar Meyer, Margaretha Buecher.

Children:

Hansz Rudolff,

Anna,

Hansz Jacob.

Unmarried:

Heinrich Schmid,

Jacob Schmid,

I 738 Caspar Buecher,

Margreth Häuser,

Children:

Heinrich,

Verena,

Hans Heinrich.

Unmarried:

Heinrich Schyblin,

Hansz Schyblin,

Lisabeth Schyblin,

Heinrich Wirth,

Anna Klayslin,

Hansz Jacob Duttweiler,

Jacob Meyer,

Barbara Meyer(in),

Total: 32 persons.
I 743 Hans Jacob Scheür Meyer, Anna Eberhardt.

Child:

Anna.

2

Hansz Bucher,

Anna Lang.

Children:

Hansz,

Anna.

Unmarried:

Hans Jacob Meyer,

Margaretha Scheur Meyer,

Heinrich Jägli,

$\left.\begin{array}{l}\text { Heinrich Surber, } \\ \text { Jacob Surber, }\end{array}\right\}$ Brothers.

No. 9i. From the Parish Wetzikon there left for Carolina IN MAY I 743

Heinrich Furrer, from Stägen, who really belongs to the Gossau district, born November 13, I691. He has with him his wife Susanna Baumann, born January 24, 1692 and the following children:

Felix, April I, I720.

Hans Jacob, October 4, 1722.

Susanna, December 31, I 724 .

Hans Felix, July 12, I729.

Anna Maria, October 8, I73I.

Barbara, May 15, 1735 .

A son Hans, born October 10,1717 , is in the Dutch service, the father wrote to him from Rotterdam that he should also make the journey with them, but he did not go. About two weeks after Whitsuntide 1743 , there also travelled thither Felix Schmid from Kempten, born January 6, I695, who was later declared a bankrupt.

Attested, Johannes Ulrich, Pastor. 
No. 92. From Wangen there went to Carolina the FolLowing Two Boys

1. Caspar Gut, baptized November I4, I713. Went there after the death of both his parents, anno $\mathbf{I} 734$.

2. Felix Hürrlimann, baptized November 26, I7 I9. Also betook himself thither after the death of his parents, anno 1743 .

Both had no more means to take along than about ro pounds, and could in no way be got away from their purpose. It happened with the knowledge of the authorities.

March 3I, I 744 .

Felix Weyss, Pastor.

No. 93. List of Persons who since I 734 AND UP to I 744 Left the Parish Weisslingen to go to the New World in Pennsylvania

\section{Anno I734}

I. Anna Juker, from Neschweil, daughter of Ulj Juker, 20 years old: Went first to Brabant to a relative, and from there she got an opportunity to go to Pennsylvania. She is also said to be married there.

\section{Anno 1736}

2. Left here, Heiniich Keller, from Theilingen, the deceased Caspar Keller's son, born February I7 I6, unmarried youth.

3. Left with the above, Christophel Jsler, from Theilingen, the deceased Hans Jszler's unmarried son, born January i $\mathrm{I}$, I7 72 .

\section{Anno 1742}

4. Ludwig Koblet, from Neschweil, 25 years old, unmarried.

5. Jacob Spörri, from Neschweil, the deceased Jacob Spörri's unmarried son: Of these four persons there has been no news until now.

6. Caspar Spörri, from Neschweil, the above deceased Jacob Sporri's son, 20 years old. The latter took with him

Anna Meilj, from Dettenried, and they are said to have been united in marriage at Basel, or on the ship.

Anno I 743

Left here, Heinrich Meilj from Lendiken:

Regula Homberger, his wife.

Children:

Verena, aged 3 years.

Jacob, aged $x$ year.

and with him Heinrich Meilj, his half-brother, aged $\mathbf{I} 6$.

The latter had been in the Dutch service since about Io years under Captain Werdmüller, and declared that he was going to Holland again. No news has been received, as to whether he remained in Holland or went to Carolina.

\section{. Felix Nüscheler, Pastor.}

\section{No. 94. Wisendangen}

\section{Very Revered, Learned and Esteemed Dean!}

In response to the command of the authorities, I am sending a list of those who emigrated from their fatherland between $1734^{-1} 744$ and were destined for the New World. 
Anno November I2, 1734

$\left.\begin{array}{l}\text { Johannes IVurman, baptized February 6, I698. } \\ \text { Elsbeth Boszhart, baptized May 3I, I696. }\end{array}\right\}$ Married January, I627.

With their children:

Anna, baptized October 31, 1728 .

Elsbeth, baptized August 27, I 730 .

$\left.\begin{array}{l}\text { Hans Heiri Wurmann, baptized, March 17, I696. } \\ \text { Magdalena Goszweiler, baptized March 15, 1707. }\end{array}\right\}$ Married November 1, I728.

With their children:

Rudolf, baptized August 2, I 729 .

Barbara, November I2, I 730.

Ursula, January 8, I 732 .

Hans Heinrich, October I 8, I 733.

$\left.\begin{array}{l}\text { Jacob Widmer, baptized August 28, I68I. } \\ \text { Margretha Deebrunner, January 8, I793. }\end{array}\right\}$ Married June I7, I 721 .

With their children:

Jacob, August 25, 1722.

Margr., January 21, I 725 .

Elsbeth, December 5, 1728 .

Suszanna, June Io, I 73 I.

Anna, March 2, I 734 .

$\left.\begin{array}{l}\text { Andreas Widmer, baptized August I I, I 696. } \\ \text { Susanna Hiltzinger, April I2, I696. }\end{array}\right\}$ Married February 3, I 728.

June 2 I, I 743

$\left.\begin{array}{l}\text { Rudolf Hegj, baptized December 6, I698. } \\ \text { Barbara Brandenberger, baptized April 20, I696. }\end{array}\right\}$ Married March 3, I 723 .

With their children:

Suszanna, April 2, 1724.

Rudolf, February I 3 , I 729 .

Hans Jacob, June I, I 732 .

Jacob, April 3, I 738 .

Hans Conrad Süsztrunk, baptized February 7, I712. Married November 30, Anna Bühlmann, February 26, I7I3.

With their children:

Jacob, November I3, 1735 .

Hans Conrad, January I, 1737 .

Magdalena, February I 5, I 739.

Ulrich, February 5, I $7+1$.

Othmar, September 30, $17+2$.

With the wish for true well-being and most reverent respect, I consign my most devoutly honored Dean to the protection of Heaven.

Wisendangen, April 10, I744.

I am His most deeply indebted servant, Hans Jacob Berger, Pastor.

No. 95. From the Parish Wyla, a year ago after Whitsuntide, the Following Persons went to Carolina

Hans Jacob Ott, from Ottenhub, aged 48 .

Lisabeth Keller,

Children:

" 35 .

$\begin{array}{lrr}\text { Elsbeth, } & \text { aged } & \text { 14. } \\ \text { Magdalena, “ } & \text { I } 2 . \\ \text { Margaretha, “" } & 8 . \\ \text { Barbara, } & \text { “ } & 3 . \\ & & \end{array}$ 
Hans Heinrich Ott, the deceased Hans Rudolff Ott's (from Ottenhub) surviving son, aged 26.

Hans Ulrich Ott, Hans Jacob Ott's son, aged 19.

Barbara Frey, Hans Jacob Frey's daughter (from the Auw), aged 24.

April 28. 1744 .

Written by Beat Kitt, Pustor at Wyla.

\section{No. 96. Froy the Parish Wildberg there wext to Carolina} IN THE YEAR 1734

Jacob Steinman, tenant on a fief at Wildberg, otherwise from the parish Schlatt, aged $\mathbf{5 5}$.

Children:

Hansz Jacob, aged 33.

Magdalena, “ “ 3o.

Heinrich, “ 29.

Hans Ulrich, " 25.

Beatrix, “ 22.

David, “ “20.

Susanna, " " 8 .

Salomon, “ I 5 .

Anna, “ I3.

This Steinmann, however, and his children are said not to have got further than the Palatinate, where they are said to have settled.

Hansz Kübler, aged about 50, from Wildberg, his wife and two children.

Hansz Jacob Jszler, aged 40, with wife and three children.

Hansz Heinrich Boszhart, from Töszegg, aged 22.

1743. Kli Jogg Meylj, from Erikon, aged 61.

His son: Jacob Meilj, aged 29.

Rägula Keller, Gotthard Keller's (the suicide's) surviving daughter from Schalchen, aged 30 .

Attested by Waser, Vicar of Wildberg.

\section{No. 97. IVYLA}

List of all those persons who since 1734 , against all warnings, went out of the land, leaving homes and fatherland. Anno 1734, September 4, there left for Carolina-

Michel Keller, from Wasterkingen, with his wife, born in Rorbas, and a child.

Jacob Nükom, from Wyl, soldier, who lately committed adultery with Anna Nükomm.

Elsbeth Witenberger, a young pretty unmarried girl, who allowed herself to be persuaded by this soldier, they wish to be united in marriage on the way.

It has not been possible to get any information about them.

Anno $174 \mathrm{I}$ in the spring there left for Carolina:

Hansz Rutschmann, from Hüntwangen with his wife, born in Bachs, and a child. Heinrich Mejer with his wife, both from Hüntwangen, no children.

Bachschlj Demuth, smith, from Hüntwangen, with his wife and a child.

Of the first two parties nothing has been ascertainable, but the smith succeeded in getting to Carolina with his wife and child, and has been able to send a letter brought by a man from Glarus, the contents of which were, that he is strong and can work well, can finally sustain himself (in the new country), that whoever is at home in his fatherland, should remain there, he wished that he had done so.

Anno 1744, March 31, there left for Pennsylvania: 
Heinrich Keller, a young schoolmaster from Hüntwangen, with his wife born in Eglisau, together with his little son, called Samuel, who according to her opinion is to become a prophet ("der nach ihrer Meinung ein Prophet werden soll").

This young schoolmaster, and the shop-keeper Bersinger from Weyach, have been agitators for many years already, and all the emigrants in the district Eglisau, and many also in Kleggau they have seduced with falsified letters and booklets. Because everything was given out to them to be so good, these people finally left their homes.

Hans Sigerist, called Müllerhanseli from Hoff Buchenlo, 60 years of age, has left his old wife malitiously.

Hans Sigerist, his son, with his wife, born in Rafz, with two little children.

Heinrich Sigerist, also from Buchenlo with his wife from Rafz and a daughter Io years old, who can read and pray very well indeed.

Magdalena Mejer, born in Hüntwangen, malitiously left her husband Heinrich Nükomm of $\mathrm{IVyl}$, and through the seduction of the above-named schoolmaster, also left with him.

N.B. The most of these emigrants could still very well have got along and supported themselves in the fatherland.

Total of all persons who left the parish WYL from I $73+$ to date is 26. The truth of this statement is attested by,

April I, I $7+4$. Marx Thomann, Pastor at Wyla.

No. 98. Fron the Parish Zell, against all Warnings aNd Adionitions, there left for the Purpose of Going to Pexisyluania, Carolina, etc., the Following Persons:

August 29, 1734

Hans Ott, Rudi's son, from UnderLangenhard, unmarried help-mate. Jacob Weckerli, schoolmaster's son, unmarried.

Boy from Zell.

Oberlangenhardt.

Hans Conradt Zuppinger.

Babelj Meyer, March I9, I689.

Children:

Margetlj, July I2, I7 8 .

Hans Uerech, September 20, 1722.

Heinrich, February I9, I730.

Hans Caspar, December 2I, I732.

Abraham Weckerling.

Catrj Meylj, April I3, I705.

Children:

Verena, January 7, I731.

Wilpert.

Hans Ulrich Nüszlj, April 5, I 705.

A man who with his wife Margreth Boszhardt led a wicked life, and from vexation left with the above.

Zell.

Hans Ulrich Näff, July 25, I 709.

Hans Ulrich's son, unmarried.

Hans Rudj Ramp, Jacob's son, baptized February I4, I717, unmarried.
Lisabeth Ott, deceased Rudi's daughter from Kollbrunnen, baptized December 20, 1726 .

Heinrich Hoffman, March 7, I697.

Susanna Meyer, April 26, 1705.

Children:

I. Verena, December I8, I7I9.

2. Anna Babelj, January 26, I72I.

3. Hans Urech, August 8, I 723.

4. Adelheit, November 4, I725.

5. Rudj, June I2, I73I.

6. Susanelj, November 4, I733. 
Bernhardt Furer, September I9, I697.

Babelj Zuppinger, August 8, 1697.

Children:

1. Heinrich, July 6, I63I.

2. Hans Rudolff, January $27,1737$.

Married July I 7, I $722\{$ Caspar Peter, October 27, I698.

Children:

I. Hans Jacob, March 4, I723.

2. Caspar, August 13, 1724 .

3. Rudolf, December 25, 1728.

4. Margeth, September 9, 1734.

5. Anna, January 19, 1738.

Married August 20, I $737\left\{\begin{array}{l}\text { Hans Ulrich Müller, June 9, I } 7 \text { I } 5 . \\ \text { Barbara Jsler, July 8, I 7 Io. }\end{array}\right.$

Child:

Heinrich, October 27, 1737.

Maria Müller, Hans Urech's sister, baptized February 5, I7I9. She went with him, but because she regretted it, she returned after a few days; is now in service in Zürich.

$$
\text { In May, I743 }
$$

Heirj Ott, Hans Rudi's (from Underlangenhardt) son, unmarried.

Jacob Ott, Hans Heinrich Ott's legitimate son, unmarried.

Magdalena Haffner, from Zell.

Heinrich Haffner's daughter, November I3, I 7 1 7 .

Maria Ott, deceased Rudi's (from Underlangenhardt) daughter, March 16, 1721.

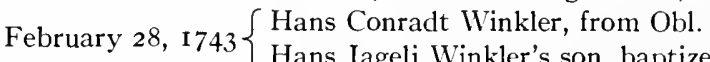

May I3, I $743\left\{\begin{array}{l}\text { Ulrich Furer, Ulrich Furrer's son, baptized August I 8, I } 720 . \\ \text { Heirj Ott, tenant's son, unmarried. }\end{array}\right.$

Total: 44 . 

Plate 12

64

(C) On. Shiladelphias Anguat $26^{\text {th }} 1735$ Prefeat

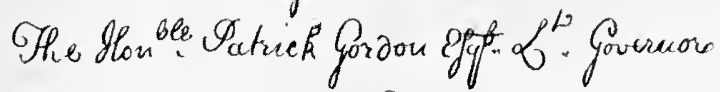
Grarles Read \&fge

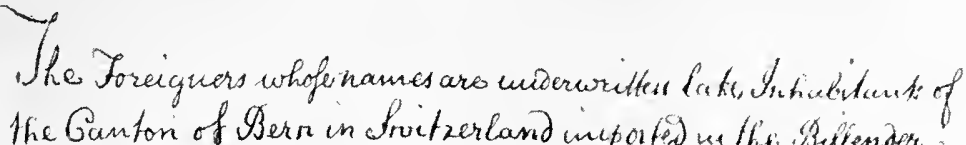

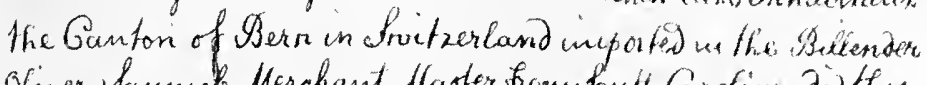

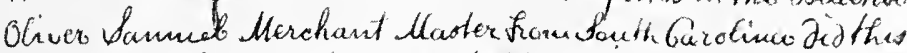
jout take o Subscribe the Waths to the Government

- goung" of bin-gates.

lazanin'ts narangars

Frang H K R Blle

Alan HL heijenturga

Griftion BR foenh obs

Otangh tckinfel bingts.

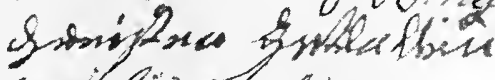

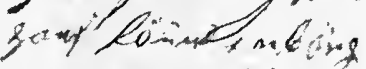

abragain minulys.

beentig wigh.

Gor ob 4 selly

irostrion $x$ weber

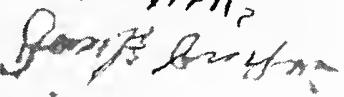

whleoh willenif

Jofoming etton

gruob withedm Doun

Reproduction of the Ship Captain's List of Inhabitants of the Canton CF Eefr, Imported from South Carolina, Philadelphia, August 26, I 735 


\section{MOVEMENTS OF SWISS EMIGRANTS IN THE AMERICAN COLONIES}

Supplemental to the preceding records, and to the statements on page I of this volume, it was my pleasure to find in Minutes of the Provincial Council (Pennsylvania), Vol. 3, p. 607, this record: ${ }^{1}$ At the Courthouse of Philadia, August 26th, I 735.

\section{Present:}

The Honble Patrick Gordon, Esqr., Lieut. Governor with some of the Magistrates.

Eighteen Switzers, who, with their families, making in all forty-five Persons, were imported in the Billinder Oliver, Samuel Merchant, Master, from South Carolina, were this day Qualified as usual, and their names are hereunto subjoined.

Bucher, Hans,

Wanger, Lazarus,

Koller, Hans,

Brenholtze, Christian,

Pingly, Hans Michel,

Swalher, Christian,

Lyinburger, Hans,

Mauslin, Abraham,

Marti, Johannes,
Meysler, Ulrich,

Stelly, Jacob,

Weber, Christian,

Willem, Ulrich,

Otter, Johannes,

Haross, Jacob Wilhelm,

Henckels, Pieter,

Lyinburger, Hans, junr..

Bucher, Hans, junr.

Pexisylyania State Librari,

Harrisburg, Pa.

${ }^{1}$ Surname placed first for easy reference

Nov. 28, I919. 


\section{MEMORANDA REFERRING TO THE ARRIVAL INTO PHILADELPHIA OF SIVISS FROM CAROLINA.}

The Division of Public Records has the original Oath of Allegiance list and also the Ship Captain's list of the Arrivals in Philadelphia from South Carolina referred to in Volume Three, page 607, Colonial Records. These lists are also published in Rupp, p. Ioo, and in the Seventeenth Volume of Second Series, pages I I9 and I20. The Seventeenth Volume of Second Series was taken from the Ship Captain's list and contains the names of the women and children, as well as of the men.

I have made a careful examination of all the lists from $\mathrm{I} 73+$ to $17+4$ and find no other lists of Immigrants coming to Philadelphia from South Carolina.

H. H. SHExk,

Custodian of the Public Records

Correspondence with Dr. Thomas L. Montgomery, State Librarian, Harrisburg, Pa., resulted in receiving from him photographs of the original records connected with the foregoing emigration of Swiss from South Carolina, and they are reproduced (see Plates I2, I3, I4) together with the memoranda from Mr. H. H. Shenk, Custodian of the Public Records.

Search in North Carolina, South Carolina, New York, Maryland, Pennsylvania, Louisiana, etc., and in the Library of Congress has yet failed to disclose any other document bearing upon this subject.

The extensive Swiss settlements in Louisiana seem to have been wholly distinct from the emigration into the Atlantic colonies. There may later be discovered records of land migration from the Carolinas other than the known movements northward into Virginia and Pennsylvania, and from Pennsylvania southward.

Gaius M. Brumbaugh

Washington, D. C., April 12, 1920 


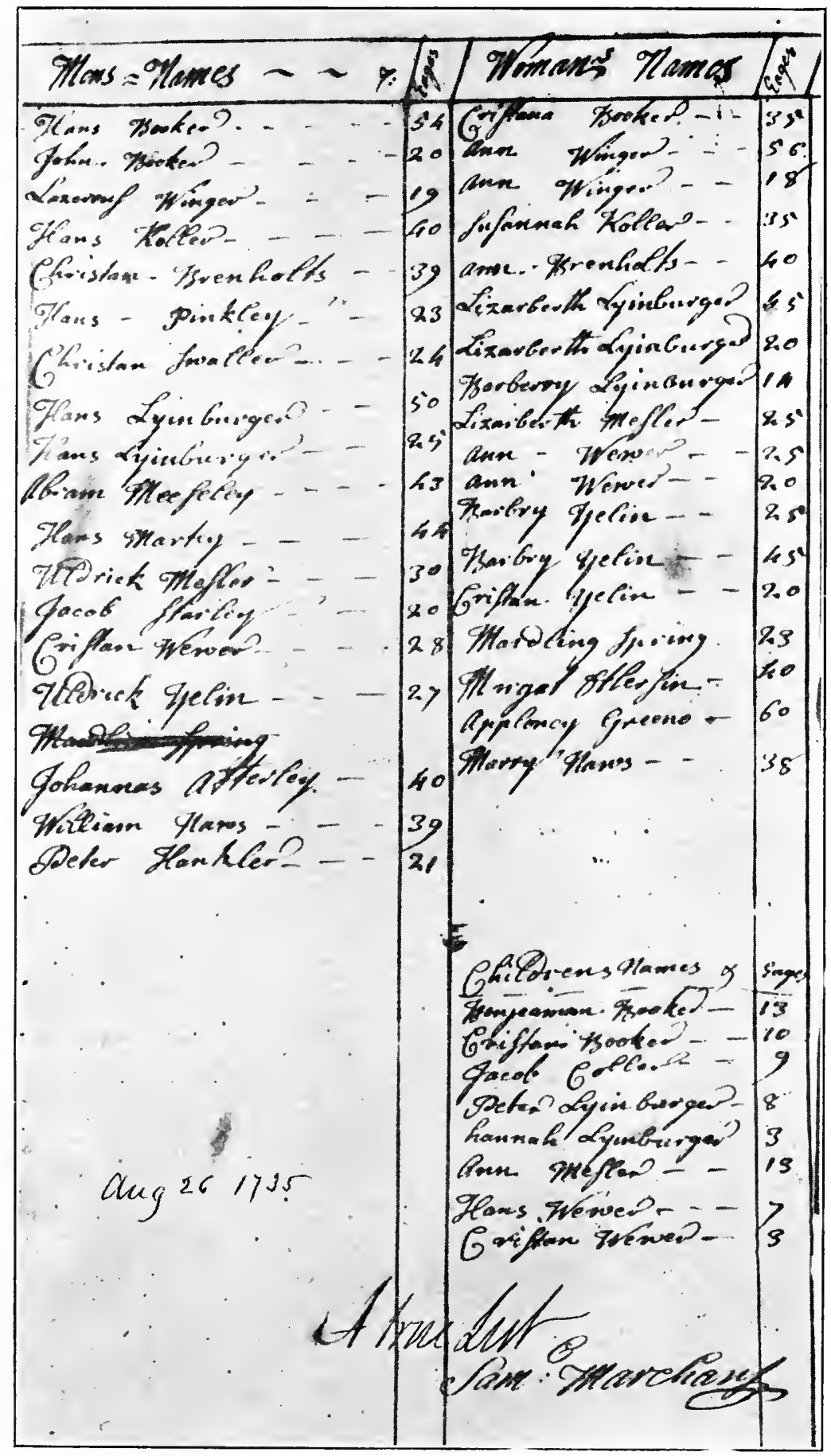

Pacie 2 of Ship Captain's List of August 26, i735 


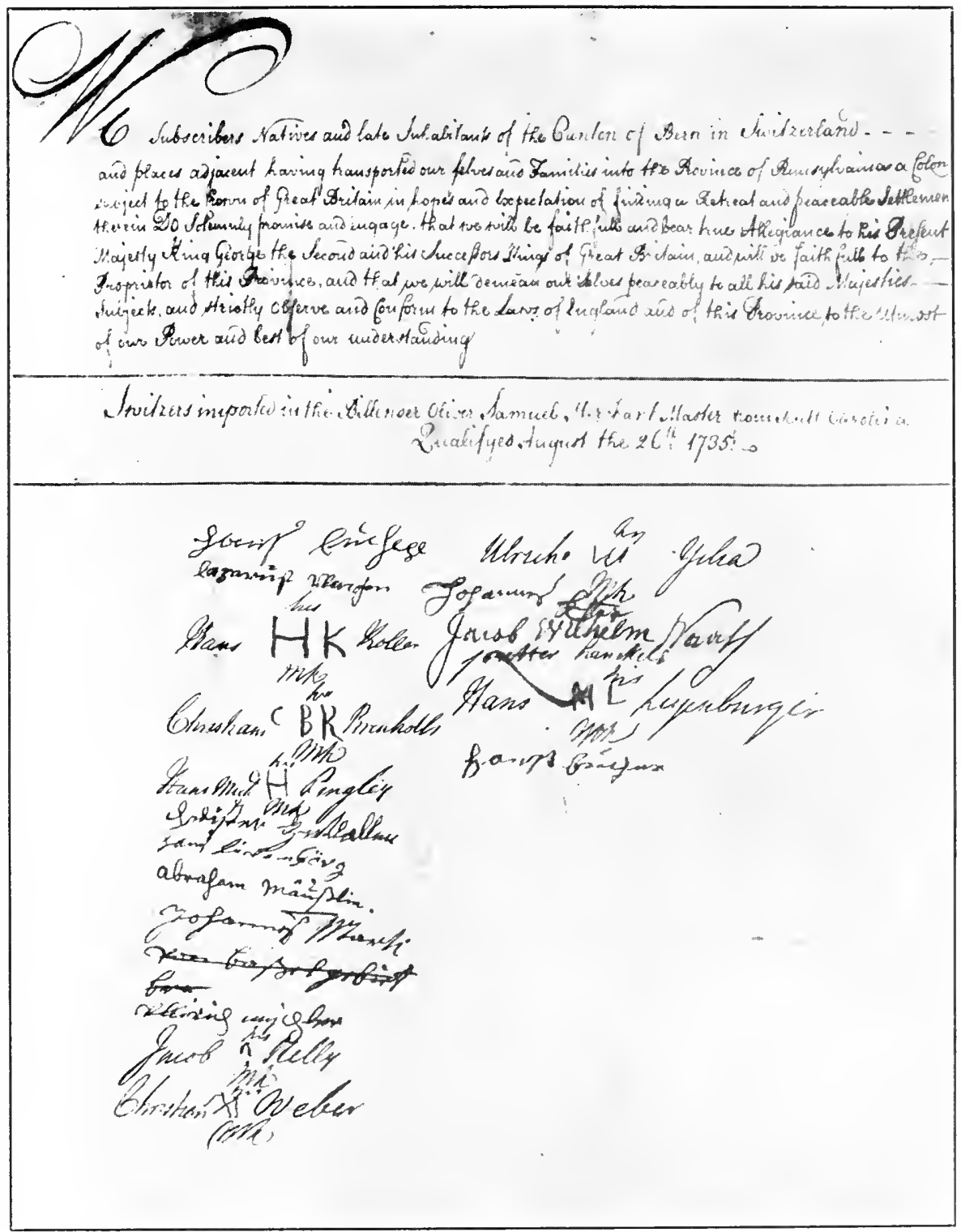

Reprodection of the Origixal OAth of Allegiance list of INhabitants of the Canton of Bers, Imported from Solth Carolina, PhilaDELPhiA, Algust 26, I 735 



\section{INDEX 1}

Aarau, 53.

Aargau, I2, 24.

Ackeret, Jacob, 69.

Aeberli, Hans Rudolf, of Jacob, 93-

Heinrich, 37.

Aeberlj, Hans, 37 (3).

Aebinger, Hans, I4.

Aeppli, Aepplj, Anna (Fenner), 49-

Conrad, 65-Elsbeth (Hotz), 65-

Hans, 65-Hansz Jacob, 49-Heinrich, 65 (2)-Jacob, 49, 65 (2)Johannes, 49-Margreth, 49Rudolff, 49-Verena (IVetstein), 49. Aesch, Aeschi, 14, 37, 56.

Aeschlikon, 45.

Affholteren, 26, 28, 30, 54 .

Aglionby, envoy, 2.

Albia, 54.

Albrächt, vii-Anna (Dubendorfer), 82-Anna (Huber), 8I-Anna (Merki), 8I-Anna (Schmid), 82-Balz, 82-Barbara, 82-Elsbetha (Meyerhofer), 94-Felix, 81, 82, 84-Hans, 82 (2)-Hans Heinrich, 8I--Hans Jacob, 8I-Hans Ulrich, 82-Heinrich, 82-Heinrich ("Kumin"), 8IJacob, 82-Joggeli, 82-Margaretha, 84-Rather, 8I-Vrena, 82.

Albrecht, Annelj, 87-Barbara, 87Barbara (Bucher), 33-Felix, 87-Hans Jacob, 87-Jacob, 87-Jacob (IVageli), 87-Johannes, 87-Margreth 87-Margreth (Moor), 87Margretha, 95--Regina, 87-Regula, 87-Verena, 87.

Allegiance, Oath of, Plates I2, I4.

Alpen-Baur. (Dunki), 76 .

Alsace, 48, 65 .
Alltstätten, Altstetten, 26, 3I, 79

Alten, 32

Altikon, 27, 30

Altlicken, 32 .

Altorffer, Anna (Frener), 36--Hans Jacob, 35-Jacob, 35-Kaspar, 35, 36-Leonard, 36-Verena (Brunner) 36.

American Historical Review, III, VII, I, 6 .

Americana Germanica, VII.

Amerikanischer Wegweiser oder Kurtze, etc., Ochs, 2.

Ammann, Anna, 45-Jacob, 3o-Johannes Caspar, 66-Ulrich, 45.

Anabaptists, 2, 3 .

Andelfingern, 27, 32, 5I, 55, 89-Klein, 32,33 .

Angst, Adam, 32-Anderson, $72-$ Barbara (Räss) 32-Barbara (Sigerist) 72-Elisabetha, 32 (2)-Hans Ulrich, 72-Heinrich, 32 .

Appenzell, 6.

Appert, Regula (Frey), 90.

Arburg, 78 .

Archives, Penna., $2 \mathrm{~d}$ Series, IO2.

Arminger, H., 63.

Atlikon, 32.

Atterley (Attersen?), Johannes, Pls. I2, I3, I4-Margat, Pl. I3.

Auer, Felix, 8I-Hans, 82 (2)-Hans Ulrich, 8I (2)-Verena (Eberhardt) $8 \mathrm{I}$-Vronegg (Lange), 83.

Augst, 26

Auspurger, Samuel, 5I

Austria, 70- War of Succession, 7.

Auw, 98.

Avis-Blättlin (Intelligencer), 22.

${ }^{1}$ Except where names are given, references to wife and children are omitted. Figures in parenthesis (3) mean that the name occurs that number of times on the indicated page.

Minor variations in spelling occur where different persons make the reports, as: Alt-stätten, Alttstätten, Ringger, Ringer, etc., but the Index presents the material variations.

The indefiniteness of knowledge of destination should cause the reader to carefully scrutinize all the "Lists" for names being sought.

The managing editor will appreciate word of any error discovered in the index, which he has carefully prepared.

G. M. B. 
Avis-blätter, Bern \& Lausanne, 22.

Azenweiler, Madalena (Huszer), 52.

Bachenbülach, $3^{8}$.

Bachmann,-, 76-Anna, 36-Anna Hinen, 36-Anna (Kreysz), 30Anna (Mantz), 64-Barbara, 42Felix, 36-Hans Casper, 36-Hans Jacob, 36-Heinrich, 36-Jacob, 36, 48 - Johannes of George, 50-Regula (Morff), 36-Rudolff, 36, 75 (2)Susanna (Ringger), 36-

Bachofen, Cleophela (Wolgemuth), 91 -Hans Jacob, 9I-Johannes, 75.

Bachs, 28, 33, 68, 98.

Baden, 38, 77, 78-Durlach, 85 .

Baggenstross, Baggenstrosz, Hans, 74 - Hans Jacob, 73, 74-Hans Ulrich, 73 (2)-Heinrich, 73-Johannes, 73, 74-Susanna, 73-Susanna (Baur), 73 -Verena, 73.

Baltensberger, Barbara (Sommer), Hans Heinrich, Lisabeth, 38.

Balthaser, Regula (Bersinger), 94.

Baninger, Abraham, $3^{8}$.

Bänk, 42-Bänken, 36, 90.

Bannerträger, I 6 .

Banninger, Elsbeth (Widmer), 63Jacob, 49-Peter, 48-Ulrich, 48, 49.

Bantli, Jacob of Rudolff, 66.

Baptists, 2.

Bär, VII,-Anna, 58-Bat. Rudolff, 58-Hans Heinrich, 58-Hans and Heinrich of Heinrich, 7I-Jacob, 4 I-Johannes, $5^{8}$-Rudolff, $\quad 5^{8}$ Verena, $5^{8 .}$

Baretschweil, 28, 34 .

Basel, v, 6, IO, I I, I3, 21, 22, 38,43 , $53,56,63,65,88,90,9 \mathrm{I}$-Lists, VIII.

Basler, Anna (Baumer) and Conrad, 31 .

Basserstorff (Bassust orf), 28, 34, 36, 6I

Bäuder-Albis, 54.

Bauer, Anna, Barbara (Müller), Heinrich (2), 80 .

Bauma, 28, 59 .

Baumann, Anna (Tobler), 92-Hans Heinrich, 92-Susanna (Furrer), 95.

Baumer, Anna (Basler), 3I-Barbel (Müller), Felix, Rudolph, 30.

Baumgartner, Andreas, 94 (4)-Anna, 94 (3)-Anna Barbara, 94-Barbara, 9t (2)-Barbara (Griesser), 94Barbara (Meyer), 94-Christofell, 94-Cleophea, 94-Elsabeth, 94Heinrich, 94 (4)-Margreth (Businger), 94-Maria, 94-Mathias, 94Rudolff, 94, 95 .

Baur, Alpen (Dünki), 76-Elizabeth (Sigerist), 74-Heinrich of Jacob, $7+$-Susanna (Baggenstosz) 73.

Bechtold, Barbara, Fronnyk (Keiser), Magdalena, Ulrich, 46 .

Beerly, Elsbeth (Gut), 37:

Belon, Magdalena (Theiler), 92.

Belz, Catharina (Schwenk), 75.

Benken, 27.

Bent $z$, Felix, 48 .

Benz, Verena (Schellenberg), 93.

Berg, 27, 42, 45, 5I, 59, 69-BergKirch, IV.

Berlin, 77.

Bern, V. 2, 4, 6, 7, 8, 9, I3, I 7, 21,24 , 51,57 , Plates I2, I4-Council of, 2, 3-Lists, VIII.

Bernhardt, Anna, Cleophea, Hans (2), Hans Heinrich, 34-Verena (Meisterhans), 32.

Bersinger,-99-Felix, M a rgret ha (Baumgartner) and Regula (Balthaser), 94-Margaretha (Meyerhoffer), 83 .

Bertschi, Dorothea (Därer), Elssbeth of Hans, Hans of Felix, 68.

Bertschj, Anna (Gaszmann), to

Bertschiken, 53.

Bertschinger, Anna Barbara (Schaub), 32-Barbara (Gimpert), 62-Margareth Gutkonecht), $67-\mathrm{S}$ us a n n (Scherer), 67.

Berüther, Barbara (IVidmer), 60.

Bible, 4, 5, Io.

Bieler, 44.

Billender Oliver, Plates I2, I +.

Binder Barbara, Barbara (Leüw), Elsbeth, Hans Heinrich, Hans Ulrich (3), Jacob, Magdalena, Magdalena (Mökli), Rudolff, Susann, Theothel, Ursula (Spallinger), 64 .

Binz, 66.

Birchwil, 35 .

Birmenstorf, 26, 37 .

Bischoff, Hans Jacob, Rodolff, etc., 50.

Blaar, Barbara (Keller), 92.

Black Forest (Baden), 38.

Blatman, Christoffel, Chrestophel, Els- 
beth (Hoffman), Hans Heinrich, Hans Ulrich, Jacob. Rudolff, 80.

Blatter, Adam, Andreas (2), B̈arbara, Barbara (Erzinger), Johannes (2), Laurenz, Magdalena, Margretha (Wuhrmann), Maria (Dietrich), Verena (2), 42.

Bläuler, Bleüwler, Sarah (Keller), 63. Bleüler, Barbara (Huber), 85-Felix, 54-Johannes of Hans Heinrich, 53-Verena (Pfister), 33.

Blickenstorffer, Blikenstorffer, Anna (Frauenfelder), 57-Barbara (Frey), 37.

Blumetshalder, 43,69 .

Bodmen, 50.

Bodmer, Cleophea, Hans, Heinrich and Regula, 50-Hans Rodolf, Regula (Gachnang), 49.

Bolsterlj, Verena (Müller), 3 I .

Bonstätten, 26-Bonnstetten, 37 .

Boop, Elsbeth (Meyer), 72.

Bosserth, Hansz Heinrich, Jacob, Rudolff, and Ursel, 49, $5^{\circ}$.

Bosshart, Boszhart, Anna (Schaub), 45-Barbara, 50-Elsbeth (Wurman), 97-Hansz Heinrich, 98Hans Ulrich, 5o-Heinrich, 45 (2), 5o-Kaspar, 45-Margreth (Nuszli), 99-Ragula (Müller), 68.

Brabant, 96 .

Braitter, Regula (Keiser), 46.

Bräm, Felix and Heirj, 86-Regula (Vrener), 33.

Brandenberger, Barbara (Hegj), 97.

Brändli, Anna (Fritschi), 77.

Brändtlen, Vrena, 6I.

Brätscher, Rägula (Kö̈lliker), IV, 59.

Brätschger, Elizabeth (Frauenfelder), 56.

Brauch, Hans Jacob of Hans Conrad, 54.

Brauen, Christen, I 8 .

Brauslen, 60.

Brenholts, Brenholtze, Christian, Pls. I2-I4, IOI-Ann, Pls. I2-I4.

Bretscher, Anna, 32-Anna (WVetzstein), 43-Heinrich, 43.

Brumbaugh, Gaius Marcus, VIII, IO2, Index.

Brüncker, Abraham, Andreas, Hans Conrad, Hans Heinrich, Hans Ulrich, Jacob, Maria Lisabeth, Regula (Herter), 48 .
Brüngger, Margreth (Gut) and Rudolff, 9 I.

Brünig Pass, I5.

Brunner, Abraham, 36-Anna (Ernin), 45-Anna (Kern), 36-Anna Margreth, 36-Anna (Meyer), 36Barbara (Redinger), 36-Barbel (Kern), 68-Caspar, 89-Christen, I9-David, 36-Dean, 36-Elisabeth (IVunderli), 66-Elsabetha (Geyer), 45-Elsbeth (Frölj) 40Felix, 36-Hans, 35, 36-Hansz Conrad, 46-Hans Heinrich, 35Hans Jacob, 36 (2), 65-Hans Ulrich, $36,45,68-$ Heinrich, 34, 36, 45 , 65-Jacob, 34-Kilian, 36Regula (Egli), 50-Rudolff, 36, 45Salome (Hursel), 35-S us a n a (Ernj), 72-Ulrich, 36, 45-Vre (Jegli), 80-Verena (Altorffer), 36 .

Brutten, 27, 38, 69.

Bubikon, 28, 38 .

Buch, 27, 5I, 69.

Buchberg, I2.

Bucher, Buecher Booker, Anna, 95Anna (Lang), 95-Benj. I3-Caspar, 95-Christina, I3-Hans Conrad, 32-Hans Heinrich, 95-Hansz, 95 (2), I OI (2), Pls. I2-I4-Heinrich, 95-Jacob, 32, 5I-John, Plate I2, I3-Margaretha (Häuser), 95Margaretha (Meyer), 95-Verena, 95.

Büchi, Anna Barbara, 47-Anna Barbara (Hegnauer), 47-Barbara (Hegetschweiler), 9I-Caspar, 47 (2)Hans Jacob, 47-Hans Ulrich, 47Heinrich, 47-Johannes, 89-Iisabeth (Keller), 47-Margaretha, 4-7 Maria, 47-Rudolph, 46, 89-Ulrich, 47 .

Buchman, Anna, 47-Elsbeth of Jogli, 67 -Hansz Conrad and Hansz Ulrich, 47-Heinrich, 47-Jacob, 47 (2), 67-Joachim, 47-Margaretha, 47-Margaretha (Schwizler), 47Salomon, 47 .

Buchsz, 40.

Büeler, John Randolff, 45 .

Buessingen, 57 .

Buhlmann, Anna (Susztrunk), 97.

Bulach, $3^{8}$.

Calais, France, $\mathbf{1 5}$. 
Cappel, 33.

Cappeler, Anna (Gering), 77-Elsbeth (Büchi), 48-Heinrich, 48-Ruedi, 49-Rudi, 48.

Carnegie Institution, III.

Carolina, III, IV, V, VIII, 9, I3, 22, $23,26,29,43,5 \mathrm{I}$ and numerous other references in the List Headings. 26-ioo.

Catholic church, 2, 5, I2, 24.

Census of emigrants, 26-Ioo.

Chlyrüdis, 37.

Christholds Gedanken, bey Anlasz Bewegung, etc.

Churches, 10-Baptists, 2-Catholic, 2, 5, I2, 24-Protestant, 2, I2Reformed, I0, 79-Uster, 90.

Chym, Ursula, 56.

Citizens rights, $89,90$.

Clingler, Johannes, 30.

Coller, Jacob, Plate I 3 .

Colonial Records, I0I, I02.

Cornell University, VIII.

Court marriage, 90.

Cunz,'Anna, Elisabeth, Elszbeth (Lang), Hans, (2), Hans Jacob, Peter Heiri, Rägula, Veronica, 83-see Kunz.

D-. Rev. Pastor in Flaach, 5I.

Dachlesen, 67.

Dägerlen, 27, 42, 45, 9I.

Dällikon, 28.

Dallweil, 26.

Dandert, Anna (Dünki), 76 .

Dändliker, 44.

Daniker, John Heinrich, 53-Salomon, 79.

Danni, Catharine (Drachssler), and Susanna (Wolffensperger) 53 .

Danzler, Jacob (3), Hans Rudolff, Magdalena (Pfister), Margaretha, 44.

Dappeler, Anna Barb. (Näff), 92.

Darer, Dorothea (Bertschi) and Hans, 68.

Das verlangte und nicht erlangte Canaan, etc., 2.3.

Dättlikon, VI, 27, 43, 69 .

Dauphine, 92.

Decrees, or mandates, $\mathrm{V}, 7, \mathrm{I}$.

Deebrunner, Margretha (Widmer), 97.

Dellickon, 43.

Demuth, Bachschlj, 98.

Dentzler, Denzler, Anna (Wegstein)
60-Barbara (Kuhn), 63-Conradt, 60.

Dependency, 29.

Der Hinckende Bott von Carolina, etc., 23.

Der Nunmehro in der Neuen Welt, etc., 23.

Detwyl, $7 \mathrm{I}$.

Die Bernische Auswanderung nach A merika, etc., 12, 24.

Diebolzau, 89.

Dielstorff, 44.

Dierauer, Johannes, 7 .

Dietlikon, 28, 36, 44.

Dietrich, Anna (Wipf), 64-Jacob, 80-Maria (Blatter), 42-Wilhelm, 80

Dietschj, Anna (Merkj), 30.

Dolder, Dorothea (Haab), 66.

Dorff, 27, 50, 69 .

Dörfflingen, 27.

Dorlikon, 30.

Drachssler, Drachszler, Catharina (Danni), 53-Heinrich, 53-Magdalena, 54 .

Drüllikon, 27.

Dübendorff, 28, 44 .

Dubendorffer, Abraham (Krebser), 35 -Anna (Krebser), 35-Anna (Albrächt), 82-Hans Jacob (Krebser), 35-Hans (Kueffer) 35-Heinrich, 35 (2)-Heinrich (Hugen), 34Kilian (Krebser), 35- Verena (Widmer), 35 .

Dünki, Anna, Anna (Dandert), Barbel (Rietiker), Cathari, Conradt (Alpen -Baur), Heinrich (2), Jacob, Jacobli, 76.

Dups, Barbara (Wyss), Hans, Hans Jacob (Heiri's), Verena (Ottlis), 29 Durlach, 32.

Dürnen, II.

Durnten, Durnthen, 28, 44.

Dutweiler, Duttweiler, Anna (Kunz), 33-Barbara, 39-Catharina, 80Ehegaumer, 80-Elisabeth (Schmid), 83-Hans, 39, 80-Hans Jacob, 95Jacob, 80-Magdalena (Huggenberger), 45 .

Dynhart, 27,45 .

Eberhardt, Anna (Meyer), 95-Barbara of Felix, 6I-Rägula, 68Verena ((Auer), 8I. 
Ebertschwyl, 54.

Ebmattingen, 65 .

Effretikon, 36, 6r.

Egg, 28, 7 I-Catharina, 5I-Rudolff of Hans Rudolff, 65.

Egli, Anna, Barbara, Caspar, Hans Jacob, Heinrich, Maria (Kägi), Regula, Salomon, 50.

Eglisau, V, 23, 28, 45, 99.

Egliss, Jacob Müller, 7o.

Egolf, Elsbetha (Pfister), Hans Rudolff (2), 71 .

Ehrensperger, Anna, 8o.

Ehrlibach, 26

Eigenheer, Regula (Sigg), 33 .

Elg, Elgg, 27, 46, 47, 69.

Elliker, Anna, Anna (Wirz), Caspar (2), Hans Heinrich, Lisabeth, Violand, 62.

Elsau, 27, 48.

Embrach, 27, 35, 36, 48, 49, 69.

Emigration census, 26-100-statistics, 24 to 26-tax, VII, II, 66, 7 I, 88.

Enderli, Anna (Keller), Hans Heinrich (Schörulis), Heinrich, Regula, 35 .

Endhörj, 39.

Engel, Verena (Gaszmann), 40.

Engeler, Anna (Wieland), 88.

England, 3, 9, 17, 19, 89.

Engstringen, 79 .

Epprecht, Anna, 3I-Anna (Grügis), $3 \mathrm{I}$-Conrad, 29-Elisabeth, 3IHans Heinrich, 29-Heirj,29-Jacob, 29, 3 I-Johannes, 29-Margreth, 3 I -Rudolph, 3I-Verena, $3 \mathbf{I}$.

Erb, Hans Rudi, I I.

Erlenbach, 49.

Ernin, Anna (Brunner), 45.

Ernj, Babelj, Heinrich, Susanna (Brunner), 72.

Ernst, Elsbetha (Weydmann), Felix, 43.

Eröffnungsrede, gehalten in der Helvetischen, etc., 7 .

Erzinger, Barbara, 42-Barbara (Blatter) 42--Barbara (Hermetschwyler), 59-Bernhardin, 42-Elsbeth (Tobler), 62-Hans, 62-Hans Jacob, 62 -Hans Rudolff, 62-Maria, 62Regula, 62.

Esch, 65.

Eschenmosen, 39.

Estate, Feudal, 63-Stäffen, 60Tetnau, 88.
Eszlinger, Matthew, 4I.

Ettenhausen, 36.

Fährli, 78, 79

Fällanden, 28, 49, 50 .

Fäsi, Dean, 58-Elsbeth (Zollicker), 48-Heinrich, 60-John, 50-Johann, 57.

Faust, Dr. Albert B., III, VIII, I, 70, 79.

Federal Emigration Bureau, Bern, 25.

Feehr, Fehr, Feer, Altorff, 28-Anna (Hartmann), 45-Conrad, 5I-Jacob $5 \mathrm{I}$-John, 72.

Fehraltorff, 91.

Felden, 69.

Feldheim, 69.

Feller, Christen, 19.

Feltheim, 27.

Fenner, Anna (Aepplj) 49-Anna (Hämming), 65-Felix, 65 (2)Hans Caspar, 65-Hans Heinrich, 65.

Feuerthalen, 27.

Fischenthal, 28, 50 .

Fischer, Susanna (Gachnang), 5o.

Fissler, Jacob, etc., 5I.

Flach, 69.

Flanders, $5^{8 .}$

Flaach, 27, 51.

Foster, Verena (Wismann), 6I .

Fralj, Junghans and Verena (Huber), 39.

France, I5, 25-Army, 63, 75-Revolution, 6, 63 .

Frankfurt, 77.

Frauenfelder, Anna, 55, 56 (3), 57Anna (Blickenstorffer) 57-Anna IVegstein), 60-Anna (Weyer), 55 -Barbara, 55 (2), 56 (2), $57-$ Barbara (Hagenbucher), 67-Barbara (Müller), 55-Bäschi, 57Conrad, 55-David, 55, 57-Deyes, 55-Elisabeth (Brätschger), 56Elsbeth, 55, 56-Elsbetha (Mäder), 56-Elsbetha (Meyer von Buech), 55-Felix son of Felix, 56-Gräzli, 57-Hans Conrad, 55-Hans Conrad's of Bäschi, 57-Hans Heinrich, 56-Hans Jacob, 57 (3)--Hans Jacob of Graz, 57-Hans Jacob (Pfeiffer), 55-Hans Peter, 57-Hans Ulrich, 57 (2)-Heinrich, 55-Isaac, 57Jacob, 55, 57-Jacob (Gabriel) 55- 
Jacob (Gräzli), 55-Johannes, 55 (2)-Jonas, 55-Joseph, 57 (2)Mathias, 55, 6I-Pantaleon, 56Ursula, 55, 56-Verena (Schaub), 55.

Frener, Anna (Altorffer), 36.

Freüdweiler, John Caspar, 48.

Frey, VII, 26-Anna Barbara, 90Anna (Schaub), 32-Barbara, 98Barbara (Blikenstorffer), 37-Caspar of Felix, 7I-Elsbetha, 90Elsbeth (Keller), 5I-Elsbeth (Lehmen), 74-Lisabeth (Zollinger), 53Elsbeth (von Tobel), 7 I-Felix, 37, 7I-Hans Heinrich, 37-Hans Jacob, 98-Heinrich, 90 (2)-Jacob, 37, 90-J. H. (Pastor), 92-Regula (Appert), 90.

Freyenstein, 76.

Freyhofer, Hans Ulrich \& Verena, 69 Fribourg, 6.

Frick, VII-Elsbetha, 54-Jacob, 58. Friedrichsthal, 85 .

Friesz, Frena (Volkert), 39.

Frik, Anna, 62-Anna Barbara, of Heinrich, 62-Anneli, 6I-Caspar, of Ulrich, 6I-Elssbeth, of Ulrich, 62-Johannes, 62-Rudolf, of Felix, 62-Ursula of Caspar, 62-Veronica (Hitz), 6I.

Fritschi, VII, Anna (Brändli), 77Anneli, 77-Babeli, 76-Barbara (Müller), 69-Clephee Babli, 77Conradt ${ }^{6} 76-$ Elsbeethli, 76-Heinrich, 76, 77-Heirechli, 76-Ragel (Hiltibrand), 76-Rodolf, 76-Vreeneli, 77.

Fröli, Frölj, Anna, 86-Anna (Huber), 86-Barbara, 40-Elsbeth (Brunner), 40-Hans Heirj, 86-Hans Jacob, 40, 86-Hanss, of Ulrich, 68-Heirj, 86-Magdalena (Gaszman), 39.

Furer, Furrer, Anna Maria, 95Babelj (Zuppinger), Ioo-Barbara, 95-Bernhardt, Ioo-Felix, 95Hans, 95-Hans Felix, 95-Hans Jacob, 95-Hans Rudolff, IOOHeinrich, 95, 100-Heirj (Ott), I00Susann (Grob), 4I-Susanna, 95Susanna (Baumann), 95-IJrich, IOO (2).

Gabriel, Jacob (Frauenfelder), 55.
Gachnang, Christoph, Heinrich, Salomon, and Susanna (Fischer), 50Regula Bodner), 49.

Gallman, Anna, of Heini, 67.

Gass, Martin, I I.

Gasser, Pastor, Io.

Gassman, Gaszman, Anna, 68-Anna (Bertschj), to-Anna Catharina, to -Babelj (Pfister), to-Barbara, 39 -Catharina, 68-Hans, 40, 68Hans Heinrich, 39-Hans Jacob, 40-Hans Martin, 40-Heinrich, 49 (2)-Magdalena Frolj, 39-Verena (Engel), to.

Geügesz, Adam, Anna, Barbara, Hans Conrad, Hans Ulrich, Heinrich, Johannes, Susanna (Müller), 42.

Georgia, 9.

Gering, Anna (Cappeler), Catharina, Conrad, Hans Conrad, Heinrich (2), Jacob, Johannes, 77-Margareth Wäber, 78 .

German American Annals, VIII.

German Element in the U.S., VIII.

German and Swiss Settlements of Colonial Penna., VII, VIII.

Germán population, VIII, I, 25.

Germantown, Pa., 46, 69.

Geschichte der Schweizerischen, etc., 7. Geschichte der Bernischen Täufer, 3.

Geszner, Hans Ulrich, 36.

Geyer, Elsbetha (Brunner), 45.

Gilg, Cilian, Regul of Chlyjoggen, 37. Gimpert, Anna, Barbara, Barbara (Bertschinger), Heinrich, Johannes (2), Lisabeth, 62 .

Gischberger, Anna, Rudolph, Ursula, 42.

Glarus, 87, 98.

Glätlj, Catharj (Huber), Felix, Heinrich, Heinrich of Caspar, 37.

Glatfelden, 28, 5 I.

Glatfelder, Anna, Anna Margareth, Barbara, Caspar, Elsbetha, Felix, Lisabeth (Lauffer), Hans Peter, Hans Rudolf, Johannes, Salomea am Berg (Walder?), Salomon, $5^{2}$.

Gordon, Patrick, IoI, Plates I2, I4.

Gossau, 27, 53, 95.

Gossweiler, Goszweiler, Hans Heinrich, 8I-Magdalena (Wurman), 97.

Göttschi, Heinrich, 6I-Pastor, 22, 23.

Graff, Graaff, Ann (Schweizer), 72Barbara, 73-Franz, 73 (2)-Hans 
Jacob, 72, 73-Hans Ulrich, 73Jacob, 6o, J. H. Graf, 2-Johannes, 73 (2)-Regula (Rebsamen), 88Susanna, 73-Verena of Hans, 74.

Graffenreid, Christoph von, VIII, I, 3-Manuscripts, 2 I.

Graubünden, 9, 12, 24.

Grazli Jacob (Frauenfelder), 55.

Great Britain, Plate I2.

Grecno, (Greene?) Appleney (2), Plate I3.

Greiffensee, 28, 53.

Grendelmejer, Anna, 4I-Barbara, 4I -Elsbeth, $4 \mathrm{I}$-Felix, $4 \mathrm{I}$-Hans Jacob, 40-Hans Rudolff, 40-Heinrich, 40, 4I-Margeth, 40, 4IUrsula, 40-Vrena (Meyer), $4 \mathbf{I}$.

Griesser, Barbara (Baumgartner), 94. Grindelwald, I6 to I9.

Grob, Anna (Schleipffer), 58-Hans, 29-Heinrich of Julius, 54-Jacob, $4 \mathrm{I}$ - Jacob of Hans, 90--Susan (Furrer), $4 \mathbf{I}$.

Grosholtz, 67.

Gross, Barbara (Städli), Felix, Hans Conrad, Hans Ulrich, Heinrich, Lisabeth, Rudolf (2), 38 .

Grügis, Anna (Epprecht), 3 I.

Grundel, Hans Jacob, of Jacob, 60 .

Grüningen, 27, 44, 65 .

Gugler, Conrad, 5 I.

Guide to the Materials for American History in the Swiss and Austrian Archives, Faust, III, 2, 4, 5, 6, 8, 9, I I, I2, I9, 20, 22, 23, 24.

Gut, Caspar, 96-Elsbeth (Beerlj), 37-Hans, 37-Johannes, of Heinrich, 7I-Margaretha, 37-Margreth (Brüngger), 9I.

Guth, Anna (Scherrer), Heinrich, 53.

Gutnecht, Andreas, Barbara, Elsbeth, Heinrich, Johannes, Margareth (Bert schinger), Marten, Susanna, 67.

Gyger, Elsbeth (Hablüzel), Herman, 89 .

Haab, Andreas, Barbara, Dorothea (Dolder), Hans Jacob, Heinrich, Regula, 66.

Haab (?), Hans Rodolff, Heinrich, Rodolff, 59.

Hablüzel, Elsbeth (Gyger), 89 .

Haffner, Dorothea (Wägmann), 60Hans, 37-Heinrich, Ioo-Lisabeth, 37-Magdalena, Ioo.
Hagenbuch, Anna, 32-Hans Heinrich, 42-Jacob, 32, 42 (2)-Johannes (2), Junghansz, Margretha, Margretha (Schmid), Ulrich, 42.

Hagenbucher, Barbara, Elsbeth, Hans Ulrich, Magdalena, Margareth, 67 .

Hagj, Barbel, Hans Jacob, Jacob, Johannes, Rägul, Vrenelj, 4I.

Hagmann, Hans Ulrich, 46.

Hakab, 36.

Haller, Barbara, Elsbeth (Näff), Hans Geörg, 93.

Hallesche Nachrichten, 79.

Hammig, Anna (Fenner), 65.

Hänsler, Hans Conrad of Kestl, 74.

Hänslj, Barbel (Schwarzenbach), 44.

Haross, Narosk, Jacob Wilhelm, Pls. I 2-I 4, IOI-Mary, Pl. I3.

Harrisburg, Pa., I OI, IO2.

Hartmann, Anna Barbara, Anna Catharina, Anna (Fehr), Hans Jacob, Heinrich, Ulrich, 45-Regula (Schneider), 46.

Hasenfraz, Anna (Meyer), 30.

Hasli, I 7 .

Haszler, Conrad, 78.

Haug, Barbara, 30-Farber, 29Johannes, 67-Leonhard, 29-Rudolff, 29-Uli, 29, 30.

Hausen, 26.

Hauser, Anna Barbara, 49-Barbara, 49-Christop, 49-Kaspar, I IMargreth (Buecher), 95.

Häussli, Elsbeth (Ochssner), Heinrich, Jacob, Joachim, 63.

Haussrad, Alexander, 7 I.

Haws (Naws?), Mary, Pl. 13.

Hedingen, 26, 57.

Hedinger, Elseli of Heiri, 57-Eva, 37 -Hans, 37.

Heffertschweil, 67.

Hegetschweiler, Anna, 7I, 9I-Anna Barbara, 9I-Barbara (Buchmann), 9I-Beat (Rudolff), 9I-Hans Heinrich, 9I-Hans Ulrich, 7I-Heinrich, 7I, 9I (2)-Jacob, 91-Margaretha, 9I-Susanna, 9I-Verena, 9I.

Hegi, Hegj, Barbara (Brandenberger), 97-Hans Jacob, 97-Jacob, 97Johann Caspar, 68-Rudolf, 97 (2)Suszanna, 97.

Hegin, Anna, 33.

Hegnauer, Anna Barbara (Büchi), 47 . 
Heinrich, Barbara, Elsbeth, Hans, Hans Geörge, Hans Jacob, 88.

Heiri, Peter (Cunz?), 83-Ruetschj, 29.

Heist, 54.

Heitz, Joh. Heinrich, 90.

Hengart, Elias-Vicar of, 5I, 69.

Henkard, Henkertt, 27, 55, 56 .

Hermetschweiler, A. Magdalena, Annelj, Babelj, Hans, Heinrich, Margreth, Regelj, 72.

Hermetschwyer, Anna, Barbara, Barbara (Erzinger), Elsbeth, Heinrich, Jacob, 59.

Herrliberg, IV, 26, 58, 66.

Herter, Anna (Müller), 70-Regula (Brüncker), 48.

Herzog, Anna (Maag), 39-Heinrich and Jacob, $8 \mathrm{I}$-Margaretha (Müller), 43.

Hess, Hesz, Anna (Knecht), 9ICaspar, 36, 9I-Hans Rudolff, 9IJacob, 36-Joh. Caspar, 3I.

Hetling, Pastor, 70.

Hettlingen, 27, 55, 69 .

Heussli, 50.

Heuszer, Hansz Conradt, 48.

Hildebrand, Hiltibrand, Johannes, of Hans Jacob, 39-Johannes, of Jacob, 39-Rägel (Fritschi), 76.

Hiltzinger, Susanna (Widmer), 97.

Himmel, Anna (Islicker), 33.

Hinckels, Henckels, Pieter, Peter, I01, Pls. I 2-I 4.

Hinderburg, 34 .

Hindermann, Margrethe, 3I.

Hindermeister, Anna, 6r.

Hinke, Dr. William J., 2.

Hinkende Bote, of Bern, 22.

Hinnen, Anna Barbara, 78-Anna (Surber), 84-Caspar, 77, 78-Elsbeth (Widmer), 77-Heinrich, 78Kilion, 44 .

Hinweil, 27, 59.

Hirt, Johannes and Magdalena (Ullman), 32.

Hirtzel, Hirzel, 26-Johann Jacob, 54Salomon, $7 \mathrm{I}$.

Hirtzwangen, 54.

History of Orangeburg Co., S. C., VIII.

Hittnau, 28, 59.

Hitz, Adelheid, Anna, Elsbetha (Frick), Heinrich (2), Verena, 54-Veronica (Frik), 6I.

Hochfelden, 39 .
Hoch-Rüti, 62.

Hoffstätter, Caspar, 37 .

Hofmann, Hoffman, Adelheit, 99Anna. Babelj, 99-Els [Elizabeth], 80-Hans Urech, 99-Hansz Ulrich, 46-Heinrich, 99-Rudj, 99-Susanelj, 99-Verena, 99.

Hofmeister, Jos. Caspar, 92.

Hofstetten, 68.

Höhn, 75.

Holland, 20, 25, 50, 57, 60, 6I, 63, 96.

Hollenweiger, Barbara (Mejer), 34.

Holzhalb, John Heinrich, 74-Leonhard, 56, 57,

Homberger, Hans Jacob, 90-Regula (Meilj), 96.

Hombrechtikon, 60 .

Höngg, 28, 30, 36 .

Honegger, Anna (Schneider), Caspar (2), Hans Jacob and Marx, 59.

Hörenen, 39.

Horgen, 26, 60, 6r.

Horger, Barbara, I3, I5.

Horner, Anna (Kern) and Daul, 39.

Hotz, Elsbeth (Aeppli), 65-Hans Caspar, 44.

Hub, 36, 67 .

Huber, VII-w. \& 8ch. 75-Anna, 85Anna, of Marti, 37-Anna (Albrächt), 8I-Anna (Frölj), 86Anna Magdalena, 85-Anna (Müller), 75-Anna (Ruetsch), $67-$ Anna (Schwab), 37-Anna (WVagmann), 63-Anna (Wyss), 29Anna (Zweidler), 87-Anna Regina (Wolfensperger), 90-Barbara, 85Barbara (Bleüler), 85-Caspar, 48, 90-Catharina, 75-Catharj (Glatlj), 37-Ehgaumer, $82-\mathrm{El}$ is a bet h (Scherer), 67-Ester (Meyer), 79Felix, 75, 90-Hans, 82, 86-Hans Jacob, 37, 39-Hans Conrad, 48Hans Ulrich, 48, 86- Heinrich, 40, $67,85,90-J a c o b, 75,90-K l j o v r e e$ (Meyer), 86-Lienhard, 86-Margreth (Weidmann), 86-Margeth (Schüz), 33-Peter, 9, I3, I9, 20Saml, 48-Ulrich, 48, 49--Verena (Mejer), 39-Verena (Hurter), 29Vronegg, 82.

Hubschmid, Catri, 57 .

Hug, Hugg, Anna, 36-Heinrich, 35Susanna (Mejer), 34. 
Hugen, Anna, 35-Barbara (Meyer), 34, 35-Christen, 34-Rudolff, 35 .

Huggenberger, Elsbeth, 80-Magdalena (Duttweiler), 45-Ulrich, 45.

Hugi, Susanna (Schmid), 54.

Humbrächtikon, 26.

Hunen, Elsbeth (Mejer), Jacob (Bieler), Regula, 4t.

Hüniken, 67.

Hunn, Barbel (Schmid), 57.

Hüntwangen, 69, 98.

Hürliman, Hurrlimann, Elsbeth \& Heinrich, 38-Felix, 96-Hans, 38Maria (Keller), 38.

Hursel, Link and Salome (Brunner), 35. Hurter, Hans Heinrich, 29.

Husen, 54.

Huser, Huszer, Anna, 81-AnnaBarbara, 84-Anna (Bucher), 87Barbara (Mayer), 83-Barbara Ortli, $8 \mathrm{I}$-Caspar, 84 -Christoph, $84-$ Felix, 8I, 83, 87,-Hans 8I (2)Hans Jacob, 52, 58, 8I, 82-Heinrich, 82 (2), 84, 87-Johannes, 84Leonhardt, 8I-Madalena (Azenweiler), 52-Rägula, 82, 84-Rägula (Mayer), 84-Verena, 8I, 82.

Illnauro, 6o.

Inäbnit, Imäbnit, etc., Peter, Io, I3, I6, I9, 21.

Interlaken, 9, I0, I 7 .

Isler (?)-see Jsler, 96.

Islicker, Anna Hegin, Anna (Himmel), Hans Jacob, 33.

Jägli, Heinrich, 95.

Jahrbuch der Deutsch-Amerikanischen, etc., von Ill., 4.

Jameson, Dr. J. Franklin, III, I.

Jauschlj, Johannes, 46.

Jeglj, Babelj, 80-Els. (Rösej), 8IHans Urech, 8o, 8I-Jacob, 8IUrech, 8o-Vre (Brunner), 80.

Jlnau, 28.

Joner, Jacob, Io, 20.

Jörlis, Haus (Sigerist), 7 .

Jsler, Jszler, Barbara (Müller), ıooChristophel, 96-Hans, 96-Hansz Jacob, 98.

Jucker, Anna, Babelj, Hans, Maria (Müller), 80.

Jud, Angelica (Steiner), 65.

Juker, Anna and Elj, 96.
Kägi, VII-Hansz Jacob, Jacob, Maria

(Egli), Marx, 50.

Käller, Heinrich, 38 .

Kämpf, Hans and Suszanna, 8 .

Käpfnach, 60.

Kappel, 26.

Karodj, Hans Jacob, 80.

Karrer, 5.

Kaüffeler, Lisabeth (Markj), 79.

Keiser, Fronnyk (Bechtold), Jacob, Marthj, Rodolff, Verena, 46.

Kelker, Kölliker, Heinrich, IV, VIIIRudolph F., IV.

Keller, 45-Abraham, 52-Andreas, 67-Anna, 93-Anna (Keller) Enderli, 35-Anna (Näff), 93-Barbara, 52-Barbara (Blaar), 92Barbara (Heinrich), 88-Bernhard, 47,52 -Caspar, 34, 51,96 -Elizabeth, 47, 93-Liszabeth (Büchi), 47Elsbeth (Frey), 5I-E li $z$ a be $t h$ (Küeffer), 35-Lisabeth (Ott), 97Felix, 5I, 67-Gotthard, 98-Hans, 5I, $5^{2}$ (2), 93-Hans Conrad, 92Hans Heinrich, 93-Hans Jacob, 5I, 67-Hans Rudolff, 67-Heinrich, 33, 5I, 63, 96, 99-Jacob, 63, 67 (2), 93-Joachim, 47-Johann, 60-Margaretha, Margeth, 33, 60Margaret (Köffel), 52-Margeth. Scheur (Mejer), 33-Magdalena, 93 -Margaretha (Meyer), 52-Maria (Hürliman), 38-M a t he us, 93Michel, 98-Rägula, 98-Rudolff, 93 (2)-Salomea, 5I-Samuel, 99Sarah (Bläuler) 63-Steffen, 5 I -Susanna, 34, 47, 52, 93-Susanna (Näff), 93-Susanna (Stephan), 67Vrena, 52-Vrena am Berg, 5I, 52. Kemleton, 60.

Kempf, Veronica (Baumgartner), 94.

Kempton, 95.

Kern, Anna (Brunner), 6I-Anna (Horner), 39-Barbel (Brunner), 68 - Hansz Jacob, $3^{8}$.

Kilchberg, 26, 31 .

Kirch-Uster, 90.

Kissling, Daniel, 2 I.

Kitt, Beat, 98.

Klaüe, Elsbetha (Siber), 88.

Klayslin, Anna, 95.

Kleggau, 99.

Klein-Andelfingen, 32, 33 . 
Kleiner, Barbara (Waaser), 7o-Rudolff, 29.

Kleinpeter, Hanss, son of, 61 .

Kloten, 28, 35, 61 .

Klupf, 80.

Knecht, Anna (Hesz) and Margretha, 91 .

Knonau, 26, 37, 54 .

Koblet, Ludwig, 96.

Koch, Anna, 4o, 85, 86-Anna (Mayer), 84-Barbara, 85-Beat. 85-Caspar, 85 (2)-Cathrina, 40, 85-Cleophee, 85-Felix, 40 (2)-Hansz, 84, 85 (2), 86-Jacob, 40-Johannes, 40, 86Joseph, 85-Kly Anna, 40-Kljannelj, 86-Kljannj Meyer, 85-Maria, 85-Michel, 85-Regula, 85, 86Verena, 85-Verena (Meyer), 85Verena (Müller), 85 .

Kocherthal, 22.

Köchli, Köchlj, Anna Maria, 83Barbara, 83-Cleophea, 83-Elszbeth (Meyerhoffer), 83-Felix, 85Hans Jacob, 83-Heinrich, 83, 85Johannes, 85-Margreth (Vogler), 85 -Verena, 83.

Köffel, Margaret (Keller), $5^{2}$.

Kollbrunnen, 99.

Koller, Hans, IOI, Pls. 12-I4-Susannah, Pl. I3.

Kölliker (Kelker), Anna, 59-Antonia, 59-Hans Caspar, 59-Heinrich IV, VIII, 59-Ragula (Brätscher), 59 -Susanna, 59-Verena (Widmer),66.

Korrodi, Pastor, 65.

Krämer, 29.

Krebser, Abraham, Anna, Anna (Wegmann), Hans Jacob (Dübendorffer), Heinrich (Dübendorffer), Kilian (Dübendorffer), Magdalena, Verena, all 35; Johannes, son of Jacob, and Rudolf, of Heinrich, 49.

Kreuzach, 77.

Kreysz, Anna (Bachmann), Hans Felix, Hans Jacob, Hans Ulrich, Jacob, 30.

Kübler, Hansz, 98.

Küeffer, Elsbeth, Hans (Dübendorffer), Hans Geörg, Katharina, Lisabeth (Keller), Rudolff, 35 .

Kuenz, Annelj (2), Barbara, Cathri, Hans, Heiri (Magistrate), Heiri, Heinrich (Engelheinrich), Johannes Margreth, 87; Jacob, and Hans Heinrich, 88.
Kuhn, Anna, 44-Anna Magdalena (Mejer), 44-Barbara (Dentzler), 63-Barbara (Näff). 93-Caspar, 44 - Felix, 44-Heinrich, 44-Lisabeth (Näff), 92-Hans, 63- Peter, 44Regula (Zöbelj), 44.

Kuhns, Prof. Oscar, VII, VIII.

Kundig, Margretta (Miller), 70.

Kunz (see Cunz, Kuhn), VII-Anna (Dutweiler), 33-Barbara, 33-Caspar, of Conrad, 65-Felix, 33-Hans, 33 .

Küssnacht, 26, 62 .

Kussnachterberg, 62.

Kyburg, 28, 55, 67, 9I.

Lake District, 26-Lake Zurich, 34 .

Land, Elizabeth and Heinrich, 82.

Landert, Ragula (Rietiker), 76.

Landicon, 37 .

Landolt, Anna, 32.

Lang, Lange, Anna, 81, 82, 83-Anna Barbara, 82-Anna (Bucher); 95Anna (Meyer), 83-Anna (Vogel), 82-Barbara, 82, 83 (2)-Barbara (Moor), 84-Deker, 84-Elsbeth (Cunz), 83-Esther, 83-Felix, 82, 83 (2)-Hans, 82,83 (2)-Hans Jr., $8 \mathrm{I}, 84$-Hans Heinrich, 8I, 82Heinrich, 82-Jacob, 8I, 83-Johannes, 8I, 83-Margareth (Maag), $8 \mathrm{I}-$ Margaretha, 83-Maria (Mayer), 82-Rägula (Müller), 82-Ragula, $8 \mathrm{I}$-Verena, $8 \mathrm{I}$-Vronegg (Auer), 83 .

Langnau, 26.

Lanu, Jacob, I4.

Lauffen, 27, 37.

Lauffer, Dorothea (Walder), Hans Jacob, Lisabeth (Glatfelder), 52.

Lausanne, 22.

Lawson, 3 .

Lee, Anna, Felix, Hans, Hans Peter, Vrena (Meyer), Vrena (Martelerj), 52.

Lehmens, Barbara, Dorothea, Elsbeth, Elsbeth (Frey), Hans Graaf, Hans Jacob, Hans Ulrich, Heinrich, 74.

Leiden (Holland), 20.

Leimaker, 50.

Leimbacher, Anna (Meyer), Barbel, Christophel, Lisabeth, Felix, Heinrich (2), Jacob, all 35: David, 49: Hans Jacob and Hans Heinrich, 36. Lenzen, 50. 
Lerch, Dr. E., I 2, 24.

Letsch, "sadler," 45.

Leüw, Barbara (Binder), 64.

Library of Congress, I02.

Lieber, Lisabeth (Peter), 47.

Lienhardt, Hans Ludwig, of Heinrich, 93.

Lier, "Beat," Heinrich, Verena (Suter), 54-Rudolf and Thommen, 4I.

Limmat, 79 .

Lindau, 28, 63 .

Lips, Anna, 86-Barbara (Rütschi), 78-Caspar, 86-Felix, 86-Hans Caspar, 86-Heinrich, 86-Melcher, 90-Regula (Näff), 86-Verena, 90.

Loch, 48.

London, VII, 9, 32, 50, 55, 70, 75 .

Luffingen, 27, 49, 69 .

Luther, Martin, V, 4 .

Luzern, 6, I2, I5.

Lyinburger, Barberry Pl. I3-Hans, IOI (2), Pls. I 2 (2), I3 (2), I4 (2)Hanah, Pls. 13-Lisabeth, Pl. I3 (2) -Peter, PI. I3.

Lyschy, Jacob, 79.

Maag, Anna (Herzog), 39-Andreas, 39-Chilion, of Chili, 68-Hansz, 38-Hans Jacob, of Alexander, 39Junghans, 33, 39-Margareth (Lang) $8 \mathrm{I}$

Majer, Felix and Magdalena, 34 .

Mandates, or decrees, $\mathrm{V}$.

Mänedorf, 26-Mannedorf, 63 .

Mannheim, 3 .

Mantz, Anna (2), Anna (Bachmann), Barbara, Conrad, Hans Jacob (2), Hans Spallinger, Hans Ulrich, Magdalena, Magdalena (Ritter), Margreth, Verena, 64 .

Mäntzin, A. Magdalena (Hermetschweiles), 72 .

Märcklin, Hans Jacob, I I .

Marithi, Verena, of Verena, 48.

Markgrafenland, 38 .

Marqualder, Maria, of Melchior, 68.

Marriage court, 53, 90.

Martelen, 27.

Marthalen, 64 .

Marti, Martey, Johannes, IOI, Pls. I 2-I 4.

Marthj, Hans, 46.

Maryland, IO2.

Maschwanden, 26, 57 .
Matrimonial court, 53, 90.

Matthysen, Jacob, dau. of, 30 .

Matthysz, Johannes, 43.

Mäuslin, Meeseley, Abraham, IOI, Pls. I2-I 4 .

May, VII.

Mayer, Anna, 84-(Anna Koch), 84Barbara (Huser), 83-Felix ("Hospel"), 84-Hans Ulrich, 84Jacob, 84-Johannes, 84, (2)-Maria (Lang), 82-Ragula (Huser), 84Verena, 84-Veronica, 84-Veronica (Schmid), 84.

Meier, Catarina of Hans, 49-see "Mejer."

Meierhofer, Heinrich, $5 \mathrm{I}$

Meilan, 26.

Meili, Meilj, Anna, 96-Heinrich, 96 (2)-Heiri, of Heiri, 57-Jacob, 96-Regula (Homberger) 96-Verena, 96.

Meister, Jacob and Johannes, 36 .

Meisterhans, Anna Elsabeth, Hans Conrad, Hans Jacob, Jacob, Verena (Bernhardt), 32.

Mejer, Meier, Anna 39-Anna Magdalen (Kuhn), 44-Barbara (Hollenweiger), 34-Catarina of Hans, 49Elsbeth (Hunen), 44-Felix, 34Hans Conrad, 39-Hans Heinrich (Mejerhofer), 39-Heinich, 98Jacob, 34-Jacob of Conrad, 39Magdalena (Nükomm), 99-Margeth Scheur (Keller), 33-Regula, 34-Salomon, 39 (2)-Susanna (Hug), 34-Verena, 34-Verena (Ruetsch), 67.

Mejerhofer, Catharina (Mejer), 39.

Mennonites, 2, 3 .

Merchant, Samuel, I01, Plates I2, I3, I4.

Meria, $5^{8}$.

Merian, M. Andreas, 43.

Merishausen, 12.

Merki, Merkj, Anna, 79-Anna (Albrächt), 8I-Barbara (Surber), 80Barbara, 79-Caspar, 30-Elsbeth (IVezstein), 92-Hans, 79, 92Hans Conrad, 92-Hans Heinrich, 92-Heinrich, 79, 92-Jacob, 79Kilian, 92-Margaretha, 79-Regula, 79-Rudolff, 79-Verena, 79Verena (Bucher), 79.

Merveilleux, 5 . 
Mesler, Meysler, Anna, Pl. I3Lisabeth, Pl. I3-Ulrich, IOI, Pls. I 2 to $I 4$.

Methodist Book Co., VII.

Metmenstetten, Mettmenstetten, 26, 67.

Meyer, VII-see also "Mejer," Angelica (Nüssli) 3I-Anna, 72 (2), 95 (2)-Anna Barbara, 4I, 87, 88Anna (Brunner), 36-Anna (Eberhardt), 95-Anna (Lang), 83-Anna (Hassenfraz), 30-Anna (Leimbacher), 35-Anna Margrett, 86Anna (Vogler), 41-Anna (Wirz), 63-Babelj (Zuppinger), ?, 99Barbara, 4I, 72, 73, 86, 95-Barbara (Baumgartner), 94-Barbara (Hugen), 34-Barbara Regula (Müller), 79-Caspar, 72 (2)-Cathrina, 4I, 88-Conrad, 4I, 79-Conradt, 63Elsbeth of Jacob, 46-Elsbeth, 4I, 5I, 72, 88-Elsbeth (Boop), 72Elisabetha (Schmid), 77-Felix, 4I (2)-Hans, 52, 72, 79, 80 (2), 86Hans Caspar, 95-Hans Conrad, 40--Hans Heinrich, 34, 4I, 77Hans Jacob, 37, 95 (2)-Hans Jacob Scheur, 95-Hansz Rudolff, 95-Hans Ulrich, 49-Heinrich, 4I, 5I, 74 (2), 77 (2), 88-Jacob, 33, 4I, 46, 5I, 73, 86, 88 (2), 95-Johann L udwig, 59-Junghans, 33Kljoree (Huber), $86-\mathrm{K} \mathrm{I} \mathrm{j} \mathrm{an} \mathrm{n} \mathrm{j}$ (Koch?), 85-Magdalena, 30-Magdalena Weidman, 40-Margaretha (Keller), 52-Margaretha (Buecher), 95-Margaretha Scheur, 95-Margretha (Theiler), 92-Maria, 30Nelchior, 40-87-Regula, 4I, 86Rudolff, 30-Susanna, 5I (2)Susanna (Hoffman), 99-Tobias, 77 -Ursula, 46-Verena, 4I (2), 86 (2) -Vrena (Grendelmeyer), 4I-Verena (Koch), 85-Vrena (Martelerj), 52.

Meyerhofer, Meyerhoffer, Abraham, 83-Anna, 83, 84-Barbara, 95Catharina, 94-Elsbetha (Albrächt), 94-Elszbeth (Köchli), 83-Hans, 84 (2), 94 (2)-Hans Heinrich, 94Hans Rudolff, 83 (2)-Hans Ulrich, 84-Heinrich, 94-Johannes, 83Margaretha, $84-$ Margaretha (Bersinger), 83-Rudolf, 9+ (2)-Susanna, 94 .
Meylen, 66-Meylen, M a r ga r e th (Burkhard), 79.

Meylj, Meilj, Meili, Cartrj (Meylj), 99-Jacob, 98-Kli Jogg, 98.

Michel, Franz Ludwig, 2, 3.

Minutes of the Provincial Council ( $\mathrm{Pa}$.$) ,$ IOI, IO2.

Mississippi, 5 .

Mökli, Magdalena (Binder), 64.

Montgomery, Dr. Thomas L., I02.

Moor, Barbara (Lang), 84-Felix, 84Hans Jacob, 84-Heinrich, 84 (2)Margreth (Albrecht), 87.

Morff, Barbara, 36-Barbara (Weber), 42-Daniel, 42-Hans Caspar, 36Jacob, 36-Jacob, 36-Regula (Bachman), 36 .

Moser, Anna, 32.

Mount Albis, 29, 30.

Mulinen, W. F. von, 4 .

Müller, Adam, 56 (2)-Anna, 7o, 82, 87-Anna (Herter), 70-Anna (Huber), 75-Anna Maria, 84-Anna (Spillman), +3-Anna (Weidman, 84-Barbara, 42, 56, 67-Barbara (Bauer), 80-Barbara (Frauenfelder), 55-Barbara (Fritschi), 69Barbara (Jsler), I I00-B a r b a r a (Schleher), 82-Barbara Regula (Meyer), 79-Barbel (Baumer), 30Caspar (Commissioner), 78-Christoph, 30-Dorothea, 3I-Elsbeth, 29-Ernst, 3-Franz, 70 (2)-Goriss (Ruff), 79-Hans, 19, 79, 82, 84 (2)Hanss Conrad, 68-Hans Jacob, 87-Hans Heinrich, 42-Hans U1rich, 31,56 , 100-Hans Urech, 100Heinrich, 4I, 42, 43, 69, 79, 84, I00Jacob, 29, 4I, 42, 69 (2)-Kungold, 70-Margaretha (Herzog), +3-Margareth (Zimmerli), 78-Maria, IooMaria (Jucker), 80-Martha, 69Ragula, 79, 80-Ragula (Bosshart), 68-Rägula (Lang), 82-Rodolff, 56-Susanna (Geügisz), 42-Ulrich, 42 (3)-Ursula, 42, 43, 56-Verena (Bolsterlj), 3I, 4I-Verena (Koch), 84,86 -Verena (Schnider), +2Verena (Süesstrunk), 56 .

Müllhaüsen, 79 .

Müllibach, 50 .

Mülliberg, 48, 49.

Munch-Altorff, 28.

Mur, 28, 45, 63, 65 . 
Murer, Anna Margeth, Elsbeth, Hans Heinrich of Jacob, Jacob, Margeth, 40.

Muschgg, Caspar, 60.

Nabholz, Prof. Hans, VIII.

Näff, VII-Anna 92 (2), 93-Anna Barb. (Dappeler), 92-Anna Barbara, 94-Anna (Keller), 93-Anna (Urner), 58-Balthaser, 93-Barbara, 93-Barbara (Kuhn), 93Beat. 93-Conrad, 29, 93-Elsbeth, -92, 93 (2)-Elsbeth (Haller), 93Lisabeth (Kuhn), 92-Elsbeth (Weber), 93-Lisabeth (Winsch), 93-Esther, 94-Hans, 94-Hans Conrad, 93-Hans Heinrich, 93 (2)Hans Jacob, 92 (2), 93 (2)-Hans Ulrich, 99-Heinrich, 93-Jacob, 92, 93 (2)-Konrad, 92-Regula, 93Regula (Lips), 86-Susanna (Keller), 93-Ulrich, 93-Verena, 93.

Nägeli, Hans, I9.

Naross, Haross (?), Jacob Wilhelm, Plates I2, I3, I4-Mary, Pl. I3.

Neerach, 87 .

Neftenbach, Nefftenbach, 27, 5I, 53, 67,69 .

Neschweil, 96.

Neubrunn, 89 .

Neuchâtel, I, 5, 6, 9, I5, I6, 22.

Neüchum, Anna (Siggin), 73-Catharina, 73, 74-Franz, 73 (4)-Heinrich, 73, 74-John, 73-Johannes, 74-Salomon, 74-Verena, 73 (3), 74-Verena (Graaf), 73

Neue Nachricht alter und neuer Merkwürdigkeiten etc., 23.

Neu-Gefundenes Eden, 23-New Eden, 23.

Neuenburg, 5 .

Neuse river, N. C., 3.

New Bern, VIII, I, 4

New York, I02.

Niderhaslen, 28.

Niderhörj, 40.

Nider-Urdorff, 90.

Niderhasslen, 68.

Niderwyl, 32.

Niehvergelt, Barbara (Sytz), 62.

Nimwegen, 3.

North Carolina, VIII, I, 21, 102, and throughout the "Lists."

Nova Scotia, Io.
Nükomm, Anna, 98-Heinrich, 99Magdalena (Mejer), 99--Michel, 98.

Nusch, Fel, 78 .

Nüscheler, Felix, 96.

Nussli, Nuszli, Angelica (Meyer), 30Anna, 3I-Barbara, 3I-Elisabeth, 30-Hansz, 30-Hans Ulrich, 99Heinrich, 3I-Margreth (Boszhardt), 99-Verena, 3I.

Ober-Affholteren, 30 .

Ober-Dürnten, 45 .

Oberembrach, 35, 48, 68 .

Oberen Strass, 54 .

Oberglatt, 28, 68 .

Oberhasli, 8, 9, I3, I8, 23.

Oberhittnau, 59 .

Oberhoff, 50.

Oberlangenhardt, 99.

Ober-Lunneren, 7 I.

Obermettmenstetten, 67 .

Ober-Ottiken, 53 .

Oberriedt, 46.

Ober-Riffenschweil, 58.

Oberschweil, 58 .

Obersteinmur, 84 .

Oberwageburg, 48 .

Oberwenigen, 80 .

Oberwill, 35, 36, 42 .

Oberwinterthur, 27, 48, 60, 80 .

Obl, roo.

Ochs, Joh. Rudolff, $2,22$.

Ochsner, Ochssner, Anna (Zuricher), 92-Elsbeth (Häussli), 63-Elisabeth (Stutz), 91-Hans, 92-Hans Jacoblj, 92.

Oeden-Hoff, 67.

Oerj, Hans Jacob, 43.

Oertlj, Anna, Felix, Hans Heinrich, Heinrich, Kljverena, Regula, to.

Oetweil, 28.

Öhrlingen, 32 .

Opfiken, 6r.

Orangeburg-Lexington, VIII.

Orell, Johann Jacob, 54 .

Örtli, Barbara (Huser), 8 r.

Ossingen, 27.

Osslingen, $7 \mathrm{I}$.

Ott, Barbara, 97-Elsbeth, 97, 99Elsbetha (Rügg), 88-Lisabeth (Keller), 97-Hans, 99-Hans Heinrich, 98, I0o-Hans Jacob, 97, 98Hans Rudi, I0o-Hans Rudolff, 98Hans Ulrich, 98-Heirj, Ioo-Heirj 
(Furer), I00-Jacob, I00-Magdalena, 97-Margaretha, 97-Maria, I00-Rudi, 99, I00.

Ottelfingen, 28, 72 .

Ottenbach, 26, 7 I.

Ottenhub, 98.

Otter, Johannes, 101.

Ottikon, 60 .

Ottlis, Caspar, 29.

Otweil, $7 \mathbf{I}$.

Palatinate, I, 21, 65, 98.

Pennsylvania, III, IV, V, VIII, I, 2, 3 , 2I, 22, 26, 29, 43, 53, 54, 96, 10I Plates I2 to I4; and throughout the "Lists"-Archives, 2d Series, I02Lebanon, IV-see PhiladelphiaState Library, IOI, IO2.

Peter, Anna, 100-Barbara, 47 (2)Anna Magdalena, 47-Caspar, Ioo (2)-Elsbeth, 47-Lisabeth (Lieber), 47-Hans Jacob, Ioo-Hans Ulrich, 47-Hugo, 47-Joachim, 47 (2)Margeth, I0o-Maria (Zuppinger), IO0-Rudolf, 47, 100.

Peyer, Balthassar, 6I-Elsbeth (Vogeler), 89.

Pfäffikon, 28, 72 .

Pfeiffer-see Frauenfelder, 56.

Pfister, Babelj (Gaszmann), 40-Barbara, 40-Dorothe, 40-Elsbetha (Egolff), 7I-Felix, 33-Hans, 33Hans Caspar, 33-Heinrich, 33, 40Jacob, 33, 40-Junghans, 40 (2)Klihans, 33-Magdalena (Dänzler), 44-Rudolff, 33-Vrena (Bleüler), 33-Vrena (Schüz), 33.

Pfungen, 27, 68, 69.

Philadelphia, Pa., III, 22, 43, 46, 68, 73, 79, IOI; Plates I2, I4.

Piedmont, 32.

Pingly, Pinkley, Hans Michel, IOI, Plates 12 to 14.

Poplizen, 72.

Protestant churches, 2 , I2.

Prussia, 70.

Purry, Jean Pierre, VIII, I, 4, 6, 7.

Purrysburg, VIII, I, 6, 9.

Queen Anne, 2.

Quinche, 9.

"Rabies Carolinae," 9.

Raafz, Rafz, 29, 72, 73, 99.
Räbstal, 90.

Ramp, Hans Rudj and Jacob, 99.

Ramsberg, 89.

Rasi, Anna (Stierlin), 37.

Räss, Barbara (Angst), 32 .

Rat, Berner, 4.

Rath, 83 .

Rathgeb, Hans Jacob, of Jacob, 93.

Ratsherren, of Bern, 5, 8, 9, 10, 21 .

Ratsmanuale, of Bern, 2, 3, II, I9.

Read, Charles, Pl. I4.

Rebsamen, Felix, Regula (Graff), 88.

Redemptioners, VII, 8, I8, 77 .

Redinger, Barbara (Brunner), 36.

Reformed church, I0, 79.

Regensberg, Regensperg, 28, 75.

Reiat, I2.

Reichenbach, I 7 .

Reiff, Elsbeth (Zollinger), 66.

Reinszfelden, 53.

Reutlinger, Hans Jacob, Kaspar, 35.

Responsa Prudentum, 12.

Reütj, 72 .

Reutschman, Conrad, Johannes, 73.

Revolution, French, 6-Revolutionary war, $4,12$.

Rhine, I3.

Richtenschsweil, Richtersschweil, VII, 26,75 .

Rieden, 44.

Riemensperger, Hans, 9.

Rieslimann, 32.

Rieth, 87 .

Rietiker, Barbara, Barbel, Caspar, Catharina, Hans Conradt, Hans Jacob, Heinrich, Jacob, Jacobli, Margareth, Regula (Landert), Verena (Hiltibrand), 76 .

Riefferschweil, 26, 58.

Rights, citizens (inheritance), V, 89, 90.

Rikenbach, 27.

Ringger, Anna of Jacob, 67-Hans Jacob, 78-Hans Ulrich, 78-Jacob, 36, 78-Margreth (Boszhardt), 78 .

Ringker, Jacob of Capt. Werner; 54.

Ritschard, Jacob, 20.

Ritter, George, 2, 3-Magdalena (Mantz), 64 .

Rorbas, Rorbass, $27,69,76,77,98$.

Röseg, Els. (Jegli), 8I.

Rosell, Hans Jacob, 67 .

Rossau, 67.

Roth, Hans, I6-Martin, 50. 
Rothenflue, Rottenfluh, I I, 49.

Rotterdam, 19, 20, 40, 95.

Rubi, Lieut., 2 I.

Ruckstul, Barbara, Barbara (Büchj), Cleophea, Hans Conrad, Hans Heinrich, Hans Ulrich, Joachim, Margreth (Egg), Melchior, Salomon (2), all 48 .

Rudlingen, I2.

Rudolf, Heinrich, Jacob, 29.

Rüegg, Anna (Zwik), 59-Barb. (Buchj), 8I-Caspar, 8I-Catharina, 89-Hans Heinrich, 89-Heinrich, 8I-Jacob, 8I (3)-Konr. 8I-Ulrich, $8 \mathrm{r}$.

Ruestin, Cathrj (Grob), 29.

Ruetsch, Anna (Huber), Barbara, Heinrich, Verena, Verena (Mejer), 67.

Ruff-see Müller, Goriss, 79.

Rugg, Elsbetha (Ott) and Hansz, 88. Rümeli, Elsbeth( Spillman), 43.

Rümikon, 38,48 .

Rümlang, 28, 44, 77 .

Rummen, Heinrich of Hans Heinrich, 80.

Rupp, I. Daniel, III, IV, I02.

Rüschlikon, 26, 3 I .

Russikon, 28, 78 .

Rutschi, Barbara (Lips), Conrad, 78 . Rutschmann, Hansz, 98.

Rutschwill, 42.

Rüthi, 28.

Rykon, 6o.

Rynthal, 89.

Ryser, Hans Jacob, 50.

Sackelschreiber Protokolle, 9.

Sagenmann, Margreht (Spullinger), 65 .

Salez, 26.

Salley, A. S., VIII.

Santee Forks, S. C., Io.

Savoy, 7 I.

Sax, 26.

Saxer, Jacob Müller, 69 .

Schaffhausen, 12, 24, 56 .

Schäfflistorf, 79 .

Schalchen., 98

Schärer, Hans Jacob, 29.

Schaub, Adam, 32-Anna, 32-Anna Barbara (Bertschinger), 32-Anna (Bosshart), 45-Anna (Frey), 32Hans Conrad, 32 (3)-Hans Jacob, 32 (2)-Hans Ulrich, 32-Heinrich, 32 (2)-Jacob, Johannes, Susanna,
Ursula, 32-Verena (Frauenfelder), 55.

Schellenberg, Felix, 88-Heinrich, 88Martin, 93-Pastor, 68-Ursula, 93 -Verena (Benz), 93.

Schenkelberger, Ester (Müller), 79.

Scherer, Scherrer, Adelheit, 67-Anna (Guth), 53-Barbara, 67-Elisabeth (Huber), 67-Gottfried, 67-Hans, 67-Jacob, 67-Susann (Bertschinger), 67 .

Scherz, Peter, I 4.

Scheuchzer, Pastor, 89 .

Schlatt, 27, 56.

Schlatter, Michael, Io.

Schleipffer, Anna (Grof), Cathri, Heinrich, Jacobi, Johannes, 58.

Schlesien, Schlessingen, 70.

Schleittheim, 56.

Schleher, Barbara (Müller), Hans Ulrich, Heinrich, Johannes, 82.

Schlieren, VI, 26, 43, 78 .

Schlumpf, Barbara (IVindsch), 6r .

Schlyniken, 80 .

Schmid, Abraham, 82-Anna Albrächt, 82-Anna (Zürcher), 65-Barbara, 83-Barbel (Hunn), 57-Caspar, 53 -Elisabeth (Duttweiler), 83-Elizabetha (Meyer) 77-Elsbeth (Weydmann), 31-Felix, 95-Fridli, 78Hans, 52-Hans Conradt, 82-Hans Jacob, 54-Hans Rudolff, 54-Hans Ulrich, 53-Hartmann, 83-Heinrich, 82 (2), 95-Heiri, 57 (2)Jacob, 40, 83, 95-Joggli, 82Johann Conrad, 54-Johannes, 53Margreth, 82-Margretha (Hagenbuch), 42-Maria, 57-Pastor, 53Regula, 54-Rudolff, 78-Susanna (Hügi), 54-Thomas, 57-Ulrich, 5I-Verena (Weidmann), 82-Veronica (Mayer), 84 .

Schnebeli, Ana, 30-Hans, 29-Leonhard, 29-Rüetschj Heiri, 29, 30.

Schneider, Anna, 46-Anna (Honegger), 59-Anna (Wintsch), 44Hans, 44-Hans Conrad, 44-Hans Jacob, 46-Hans Rudolff, 44-Heinrich, 44-Jacob, 46-Jacob Rathgeb, 44-Regula, 44-Regula (Hartmann), 46-Regula (Utzinger), 46Rodolf, 46.

Schneit, 47.

Schnetzer, Verena, 46. 
Schnöfflistorf, 28.

Schönenberg, 26, 92.

Schonenberger, Hans Ulrich, 50.

Schoop, Joh, 33.

Schörulis, etc., 35 .

Schottiken, 46,47 .

Schüpfen, 82 .

Schupisser, $4^{8}$.

Schurter, Caspar, 5I-Hans Jacob of Krauszli Hans, 76.

Schütz, Elsbeth (Volkart), 68.

Schüz, Anna, Barbara, Elsbeth, Hans, Hans Heinrich, Hans Jacob, Jacob, Margaretha (Schmid), Margeth (Huber), Vrena (Pfister), 33-Vrena (Bernhardt), 34.

Schwab, Anna (Huber), Barbara, Caspar (Toggweiler), Hans Heinrich, Margreth, 37 .

Schwällj, Barbara (Weisz), 43.

Schwarz, Hans Ulrich, of Jacob, 42.

Schwarzenbach, Barbel (Häusli), Felix, Heinrich, Ulrich, 44.

Schweizer, Schweyzer, Ann (Graaf), 72-Johann Caspar, 34-Susanna Baggenstoss), 74 .

Schwenk, Anna, Anna-Marja, Catharina (Belz), Elisabetha, Esther, Jacob, Johannes, 75 .

Schwertzenbach, 28, 80 .

Schwizler, Margaretha (Buchmann) 47 .

Schwytzer, Johannes, 90.

Schyblin, Hansz, Lisabeth, Heinrich, 95.

Seebach, 43 .

Seen, $27,51,80$.

Seglingen, 46.

Seiffert, Sara (Steinmann), 56.

Sennhauser, Dorothea (Wy-man), $5^{8}$.

Sennwald, 26.

Senscheür, 9I.

Seüzach, 27, 69 .

Shenk, Hiram H., IO2.

Ship-lists, III, IV, I I, Plates I 2-I 4 .

Siber, Anna, Elsbetha (Klaüe), Hans Caspar, 88.

Sigerist, Anna, 74-Anna (Wildberger), 74-Barbara, 74-Barbara (Angst), 72-Elisabeth (Baur), 74-Franz, 74-Hans, 74, 99 (2)-Hans Jacob, 74 -Hans Ulrich (Melchers), 74Heinrich, VII, 99-Johannes, 72Susanna, 74 .
Sigg, Hans Jacob, Jacob, Margaretha, Regula (Eigenhier), 33.

Silesia, Prussian, 70.

Simler, Pastor, 40.

Smith, Henry A. M., VIII, 6.

Solothurn, I2, 24.

Sommer, Barbara (Baltensberger), 38 -Ursula of Jacob, 45 .

South Carolina, VIII, I, 6, I0, IOI, I02, Plates I2, I4-South Carolina Hist. Mag., VIII, 6.

Spallinger, Heinrich, Ursula (Binder), 64.

Spanish service, 90.

Speker, Anna Barbara, 46.

Spillman, Caspar, Elsbeth, Hanseli, Heinrich (2), Verena, 43.

Spörri, Caspar, Jacob (2), 96.

Sprenger, Hans Ulrich, 46.

Spring, Mardling, Plate I3.

Sprungen, 64.

Sprüngli, Heinrich, 88.

Spullinger, Anna, Barbara, Georg Hans Jacob, Margreth (Sagenmann), 65.

Stadel, 28, 81, 82, 83, 84, 95.

Stadeli, Barbara (Gross), 38.

Stäfa, 7 I-Stäfan, 26.

Stäffen, 63-Estate, 60-Barbara, 38 Verena, 38 .

Stägen, 95 .

Stähli, Uli, 57-see Stelly.

Stallikon, 26.

Stammheim, 27.

Stapfer, Anna, of Hans Jacob, 45.

Statistics, III, 24.

Steffi sburg, 8.

Stein, 27, 45 .

Steiner, Angelica (Jud), 65-Barbara, 65-Caspar, 39-Hans Conrad, bro. of Seepe, 57-Heinrich, 65-Johanes, 39.

Steinman, Anna, Beatrix, David, Hans Ulrich, Hansz Jacob, Heinrich, Jacob, Magdalena, Salomon, Susanna, 98.

Steinmann, Anna Martha, Deyes, Johann Conrad, Lorenz Simeon, Sara (Seiffert), 56.

Steinmaur, 28-Steinmur, 84.

Stelly, Starley, Jacob, Ioo, Pls. I2-I 4, Sterchi, Landsvenner (Bannerträger), I6.

Sternberg, 27, 88 . 
Stierlin, Anna (Rasi), Gregorius, Hans Jacob, Ursula, 37.

Stoker, Peter, 2 I.

Strassburg, 57.

Sträuli, Jacob, of Caspar, 60.

Streiff, Hans Jacob, Melcher, 87.

Striker (Stryger), 8-Hans Georg, 2I.

Strüb, - 79.

Studer, Johannes, 36.

Studies in Pennsylvania German Family Names, VII.

Stüdli, 6I.

Stuki, Barbara (Hugenbergerin), Daniel, Jacob (2), Johannes, Peter, Ulrich, 42.

Stutz, Barbara, Caspar, Elisabeth (Ochsner), Heinrich, Ulrich, 9I.

Stuzin, Anna (Walder), 53.

Süessrtunk, Verena (Müller), 56 .

Suicer, Conrad, 49.

Sulgen, 73 .

Sultzbach, 90.

Sulz, 45 .

Sünnicken, 86,87 .

Surber, Anna (Hinnen), 84-Anna (Weidmann), 34-Barbara (Merkj), 90-Caspar, 80--Hans, 80-Hansz, 84-Hans Caspar, 85-Hans Heinrich, 85-Heinrich, $80,84,95-$ Jacob, 8o, 95-Susanna, 80-Verena, 84,85 .

Susstrunk, Barbara, Hans Ulrich, Heinrich, Ursula (Üly), 33.

Süsztrunk, Anna (Bühlmann), Hans Conrad (2), Jacob, Magdalena, Othmar, Ulrich, 97.

Suter, Sutter, Hans, Hansz Jacob, Heinrich, Rudi, 29-Heiri, 67Verena (Lier), 54.

Swalher, Swaller, Christian, IoI, Plates I 2, I3, I4.

Snyder, Hans Jacob, of Marx, $7 \mathrm{I}$.

Sytz, Anna, of Heinrich, Anna (Walder), Barbara (Niehvergelt), Hans Jacoli, Heinrich, 6I (2) and 62, Regula, of Heinrich, 62.

Tagelschwang, 35 .

Tanner, w. and $6 \mathrm{ch}$., 75 .

Tax, emigration, VII, I I, 66, 7I, 88 .

Tetnau Estate, 88.

Thal, 69.

Theiler, Elsbeth, Hans Jacob, Hans
Rudolff, Johannes, Magdalena (Belm), Margretha (Meyer), 92.

Theilingen, 96.

Thirty Thousand Names, etc., Rupp, III, IV.

Thomann, Marx, 99.

Thun, I5, I9, 2 I.

Tobel, Jacob von, $7 \mathrm{r}$.

Tobler, Anna (Baumann), 92-Elsbeth (Erzinger), 62-Pastor, 66.

Todd, Vincent H., VIII, 4 .

Toggenburg, 9, 88 .

Toggweiler, Anna (Huber), Caspar (Schwat), 37.

Töss, Tosz, 27, 69, 88 (2).

Töszegg, 98.

Trachsler, Anna Maria (Vogler), 46.

Trent River, N. C., 3.

Trindler, Anna (Frauenfelder), 6I.

Trüb, Anna, 66-Hans Jacob, 86Heinrich, 66-Jacob, 86.

Trüllikon, 88 .

Trutikon, 88.

Turbenthal, 27, 89 .

Uessikon, 66.

Uetikon, 26, 7 I.

Uhwisen, 89 .

Ullman, Hans, Hans Jacob, Magdalena (Hirt), 32.

Ullrich, Ulrich, Caspar, 3I-Heinrich, 4I-Johannes, 95-Johann Heinrich, 63-John Jacob, 90.

Uly, Ursula (Susstrunk), 33.

Under Langenhardt, 99, I o0.

Under-Lunneren, 71.

Under-Rifferschweil, $5^{8}$.

Underwagenburg, 49.

Unter-Affholteren, 30.

Untermellmenstetten, 60 .

Untermetterstetten, 48 .

Unterseen, 14.

Unterwalden, I5.

Undorff, 26, 90.

Urner, Anna, Anna Näff, Heinrich, Johannes, Verena, $5^{8}$.

Uster, 28, 66, 7I, 80, 90-Church, 90. Usteri, Dean, 67-Hanss Caspar, 68.

Utenberg, 62.

Utikon, 26, 67 .

Utzinger, John Jacob, 44.

Vaud, 6.

Veldheim, 46.

Vetter, Elsbeth, Jacob, 35 . 
Virginia, 2, 102-Magazine of History,2.

Vogel, Anna (Lang), 82-Margaretha, of Heinrich, 53-Margreth (Köchlj), 85.

Vogeler, Vogler, Anna Magdalena, 46Anna Maria (Trachsler), 46-Anna (Meyer), 4I-Caspar, 46-Elsbeth (Peyer), 89-Hans Ulrich, 46 (2), 89-Hansz Heinrich, 46-Hansz Jacob, 46-Johan. Felix, 76-Pastor and Chamberlain, 75 .

Volkart, Anna, Elsbeth (Schütz), Felix, Hanss, Hans Heinrich, Heinrich (2), Margreth, 68.

Volken, 5I, 70.

Volkert, Frena (Friesz), Joseph, 39.

Volketschweiler, 9I.

Volkhart, Hans Heinrich, Heinrich, Jacob, 86.

Volketschweil, 28.

Vollenweider, Hans Heinrich, 78Ulrich, $4 \mathrm{I}$.

Von Tobel, Elizabeth (Frey), Jacob, 7I. Vrener, Caspar, Klihans, Regula (Bräm), 33.

Waaser, Barbara (Kleiner), Christen, Jacob, 70 .

Wäber, Anna Maria (Weidmann), 77Caspar, 78-Johannes, 58, 78Nargareth (Gering), 78-Ulrich, 58 .

IVädenschweil, Wädeschweilen, 26, 92.

Wägmann, Anna, 63-Anna (Huber), 63-Barbara, 63-Dorothea (Haffner), 60-Hans Caspar, 63-Hans Jacob, 63-Hans Ulrich, 63-Heinrich, 63-Jacob, 60-Margaretha, 63-Regula, 6r.

Wald, 28, 50.

Walder, Anna, 62-Anna (Stuzin), 53-Anna (Sytz), 6I-Anna (Weiss), 62-Dorotheai, 62-Dorothea (Lauffer), 52-Felix, 52-Hans Jacob, 62 -Hans Jacobli, 62-Heinrich, 52, 6I-Jacob, Io, 53-Leonhard, 62Rudolf, 53-Verena (Epprecht), 29 -Vreneli, 62.

IVallisell, 6I-Wallisellen, 29, 34, 35, 92.

Wangen, 28, 36, 96.

Wanger, Winger, Ann, Pl. I3 (2)Lazarus, IOI, Pls. I2-I 4.

Waser, Jacob, 70-Ulrich, of Joseph, $4^{2-V i c a r,} 98$.
Wasterkingen, 98 .

Watt, 43.

Wattenwyl, 2I.

Weber, Wewer, Ann, Pl. I3 (2)-

Barbara (Morff), 42-Christian, IoI;

Pls. 12, I3 (2), I4-Elsbeth (Näff), 93-Hans Pl. 13-Heinrich, 58Jacob, 58 .

Weckerli, Jacob, 99.

Weckerling, Abraham, Catrj (Meylj), Verena, Wilpert, 99.

Weggmann, Anna (Krebser), 35.

Weidmann, Anna, 3+ (3), 87-Anna Maria (Wäber), 77-Anna (Müller), 84-Anna (S u r ber), 34-Anna (Zweidler), 87-Felix, 34-Hans, 34 -Hans Jacob, 34, 87-Heinrich, 34, 87 (2)-Joggli, 82-Johannes, 34Judith, 77-Magdalena (Meyer), to -Margreth (Huber), 86-Regula, 87-Rudolff, 34, 77, 82 (2)-Verena (Schmid), 82,-see IVeydmann.

Weil, 56 .

Weiningen, 28.

Weiss, Weisz, Anna (Walder), 62Barbara (Schwällj), 43-Regula, 43 -Rudy, 43-S., 50 .

Weisslingen, 28, 96 .

Weltj, Anna, Clein-Anna, Barbara, Hans, Heinrich, Rudolff, 72.

Weni, Heinrich, 56 .

Wenningen, 28, 95 .

Werder, Salomo, of Bernhardt, 63.

Werdmüller, Captain, 96.

Werndtlin, Esther, 22.

West Indies, 49, 63, 7o, 75 .

Wetstein, Verena (Aepplj), 49.

Wetzikon, 27, 45, 95.

Wetzstein, Anna (Bretscher), Jacob, +3 .

Weyach, 29, 99.

Weydmann,- - see Weidmann-Elsbetha (Ernst), Heinrich, Jacob and sister, 43-Christoph, Esbeth (Schmid), Hans Caspar, Heinrich, Ulrich, $3 \mathrm{I}$. Weyer, Anna Frauenfelder, 55.

Weyss, Felix, 96.

Wezstein, Anna (Denzler), Anna (Frauenfelder), 60-Elsbeth (Merki), 92 -Hanss, 60.

Widmer, Andreas, 97-Anna, 66, 97Barbara (Berüther), 60-Elssbeth, 63 (2), 66, 97-Elsbeth (Banninger), 63 -Elsbeth (Hinnen), 77-Felix, 
6o-Hans Felix, 35, 63-Hans Jacob, 58,66 -Heinrich, 66-Jacob, 63, 97 -Margaretha 63, 97-Margaretha (Diebrunner), 97-Susanna, 97Susanna (Hiltzinger), 97, Verena (Kölliker), 66-Verena (Dübendorffer), 35 .

Wieland, Anna (Engeler), Conrad, Hans Conrad, Hans Rud., Lisab., Urss., 88.

Wild, Philip, 19.

Wildberg, 27, 98.

Wildberger, Anna (Sigerist), 74 .

Willem, Barbry, Pl. I3 (2)-Cristan, Pl. 13-Ulrich, Uld ri ck, IOI ; ("Yelia," "Yelin"), Pls. I2, I3, I4.

IVilliam and Mary College, 2.

Willikon, 7I.

Windlach, 81, 82, 83 .

Windisch, Windsch, Winsch, Caspar (Schlumpf), 6I-Lisabeth (Näff), 93-Regula (Buchmann), 67.

Winkel, 39.

Winkler, Hans Conradt, Hans Jagelj, Ioo.

IVinterberg, 63 .

Winterthur, 27, 32, 48, 69 .

Wintsch, Felix and Katharina, 37see Winsch.

Wipf, Anna (Dietrich), Barbara of Georg, Elsbeth, Hans Jacob, Heinrich, Johannes, 64 .

IVipfen, Bernet (wife), 49.

Wirt, Wirtz, WVirz, VII, Anna (Elliker), 62-Anna (Meyer), 63-Hans Heinrich, 44-Hans Jacob, 9I-J. Conrad, 47 -Jacob, 62 .

Wirth, Chamberlain 90-Heinrich, 95.

Wisendangen, 27, 56, 96.

IVismann, Anna, Felix, Verena (Foster) $6 \mathrm{I}$.

Wisz, 75.

Witenberger, Elsbeth, 98.

Wolfer, Verena, 42.

IVolff, Wolf, Johan Jacob, 75-Pastor, 77,95 .

Wolffensberger, Anna, Anna (Dändliker), Hansz, Jacob (2), Regula, 42.

IVolffensperger, Anna, 90-Anna, of Jacob, 54-Anna Regina (Huber), 90-Cleophea, 90-Elisebeth, 53, 90-Hans, 90 (2)-Hans Jacob, 53Margaretha, 53-Maria, 53-Susanna (Danni), 5.3.
Wolgemuth, Cleophela (Bachofen) and Hans (2), 9I .

Wollishoffen, 26, 3I, 60 .

Wollnau, 59.

Wolsen, 7I.

Wüest, Hans Conrad, 54-Hans Jacob, 54-Jacob, of Hans Heinrich, 93.

Wuhrmann, Margretha (Blatter), 42.

Wulfingen, 27, 69 .

Wunderlich, 5 .

Wunderli, Wunderlij, Bernhardt, 62 (2)-Conrad and Maria, 66-Elsbeth, 66-Elisabeth (Brunner), 66Heinrich, 66-Magdalena, 66-Pastor, 37 .

Würgler, Hanss and Verena (Morff), 61 .

Wurman, Anna, Barbara, Elsbeth, Elsbeth (Boszhart), Hans Heinrich, Hans Heiri, Johannes, Magdalena (Goszweiler), Rudolf, Ursula, 97.

Würtemberglands, 78 .

Wüst, Jacob, Leonhardt, 8I.

Wyach, 94.

Wyl, Wyla, VI, 27, 29, 97, 98 (2).

Wy-man, Barbara, Dorothea (Sennhauser), Elsbeth, Hans Heinrich, Heinrich, Jacob, Rudi, Verena, 58.

Wyss, Wysz, Anna, Babelj, Betelj, Els (2), Hofman, Hans, Vre, 80Conrad, 29-Felix, 29-Hans, IoHans Ulrich, 3 o.

Yverdun, Io.

Zanger, Heinrich, 39

Zaugg, Peter, 16.

Zehender, Hans Ulrich and Martj, 89.

Zell, 27, 99.

Zeller, minister, 45.

Ziegler, Christophel, 62-Conrad, IV, 59-Salomon, 69.

Zimickon, 9 I.

Zimmerli, Margareth (Müller), 78 .

Zöbeli, Zöbelj, Hans (2), Jacob, $80-$ Regula, 44.

Zollbrück, I4.

Zollicker, Elsbeth (Fäsi), Hans, Heinrich, Kilian, 48.

Zollinger, A. Barbara, 38-Andreas, 53-Anna, 66-Anneli, 53-Babeli53-Casperli, 53-Conrad, 38-Els, beth (Reiff), 66-Lisabeth, 38Lisabeth (Frey), 53-Felix, 66 (2)- 
Hans Caspar, Hans Ereth, Hans Heinrich, Hans Jacob, 38-Hans Jacob, 66-Jacob, 53-Regula, 38Rudolf, 38 .

Zumikon, 26.

Zuppinger, Abraham, $50-\mathrm{B}$ a be $1 \mathrm{j}$ (Furer), roo-Babelj (Meyer), 99Hans Caspar, 99-Hans Conradt, 99-Hans Jacob, 50-Hans Uerich, 99-Heinrich, 99-Margetlj, 99Maria (Peter), Ioo.

Zürcher, Anna (Schmid), Elsbetha,
Hans Jacob, Hans Ulrich, Leonhardt, 65 .

Zurflüh, Hans, ıo.

Zürich, IV, V, VIII, 6, 7, 9, 10, 22, 23, 24, 26, 46, 54, 6I, 78, I0o.

Zuricher, Anna (Ochsner), 92.

Zursach, 60.

Zweidlen, 53-Zweidler, Anna (Huber), 87-Anna (Weidinan), 87-Hans Heiri, 86-Heinrich, 86-Mathys, 86.

Zwik, Anna (Rüegg), 59-Heinrich, 59.

\section{NOTICE.}

The National Genealogical Society, Washington, D. C. (Chartered 1903) welcomes applications for active membership and subscriptions for its publication, The National Genealogical Society Quarterly (Established April, 19i2). It also desires to receive and review in the Quarterly important publications which it will add to its library, to receive donations for the said library, and to receive and publish valuable unpublished genealogical and historical materials. It will appreciate the further cooperation of every reader of this volume.

Frank Sylvester Parks, President, 1609 Hobart, N. W.

Mrs. Gaius M. Brumbaugh, Cor. Sec., 905 Mass. Ave., N. W.

Dr. Gaius M. Brumbaugh, Editor, 905 Mass. Ave., N. W.

Miss Cora C. Curry, Librarian, iozo Monroe, N. W.

Alfred B. Dent, Treasurer, Care Washington Loan \& Trust Co. July 6,1920 . 



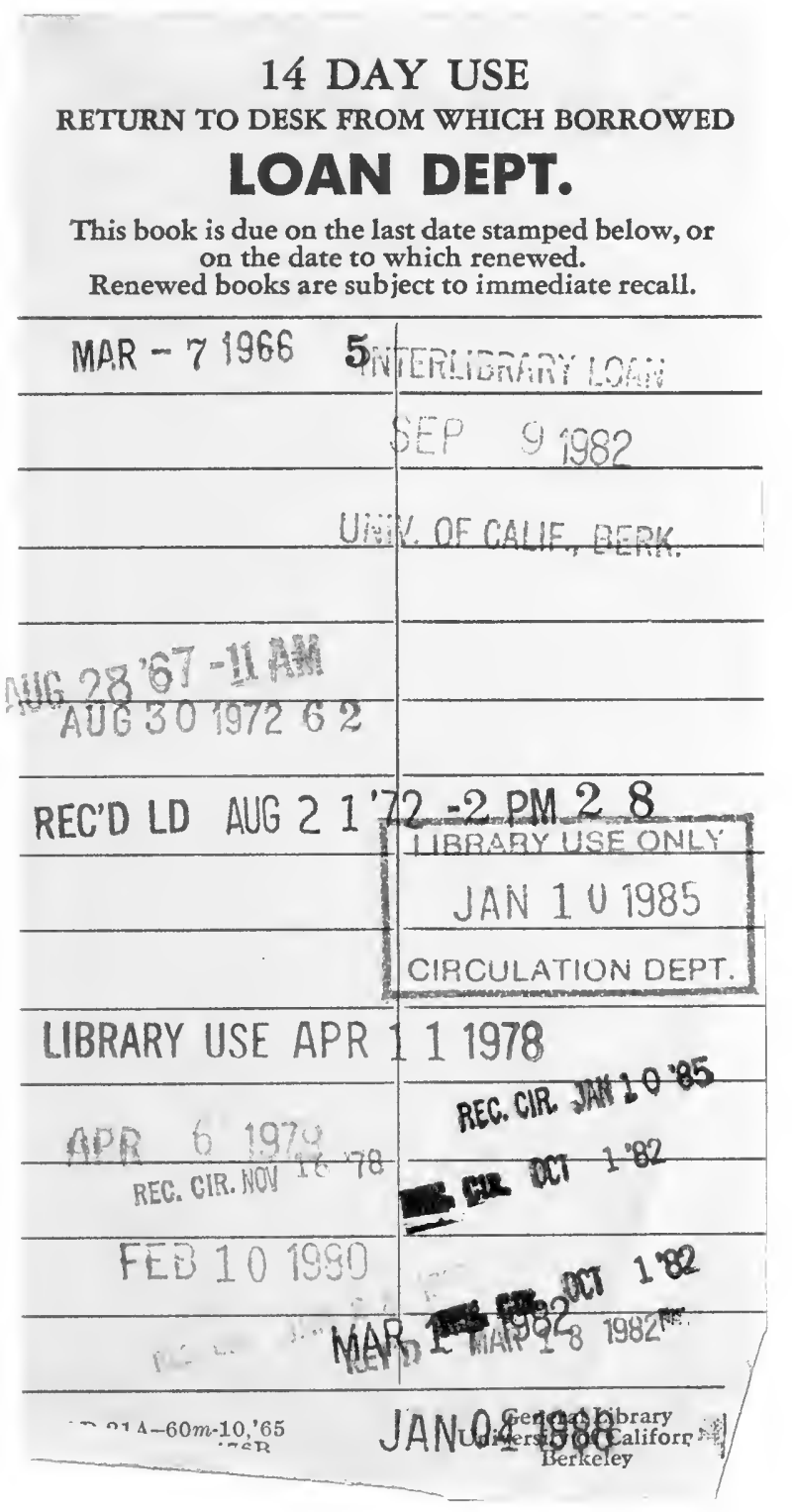




\section{U.C. BERKELEY LIBRARIES}

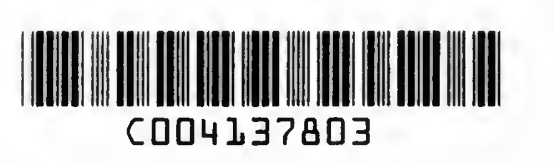


